The science-practice interface in Ecology and Conservation: a conceptual framework and shared ways of thinking among scientists and decision-makers

A interface ciência-prática em Ecologia e Conservação: um esquema conceitual e modos de pensar compartilhados entre cientistas e tomadores de decisão

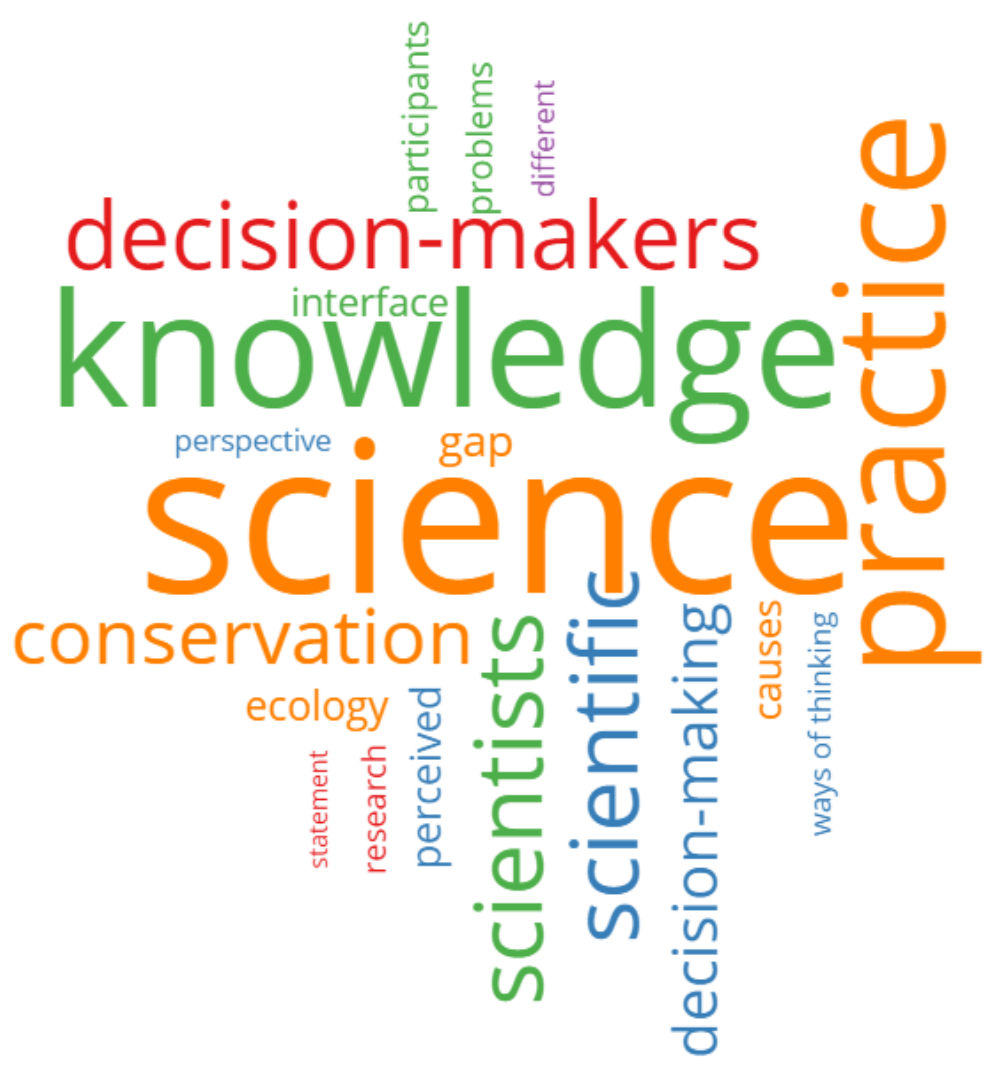

Diana Bertuol Garcia

São Paulo 


\author{
Universidade de São Paulo \\ Instituto de Biociências \\ Programa de Pós-Graduação em Ecologia
}

\title{
The science-practice interface in Ecology and Conservation: a conceptual framework and shared ways of thinking among scientists and decision-makers
}

\begin{abstract}
A interface ciência-prática em Ecologia e Conservação: um esquema conceitual e modos de pensar compartilhados entre cientistas e tomadores de decisão
\end{abstract}

Diana Bertuol Garcia

Dissertação apresentada ao Instituto de Biociências da Universidade de São Paulo, para a obtenção de Título de Mestre em Ciências, na área de Ecologia.

Orientadora: Profa. Dra. Renata Pardini

São Paulo 


\section{Ficha Catalográfica}

Garcia, Diana Bertuol

The science-practice interface in Ecology and Conservation: a conceptual framework and shared ways of thinking among scientists and decision-makers.

Versão em português: A interface ciência-prática em Ecologia e Conservação: um esquema conceitual e modos de pensar compartilhados entre cientistas e tomadores de decisão.

$177 \mathrm{p}$.

Dissertação (Mestrado) - Instituto de Biociências da Universidade de São Paulo. Departamento de Ecologia.

1. Science-practice gap 2. Science communication 3. Decision-making 4. Policy-making 5. Ecology 6. Conservation science I. Universidade de São Paulo. Instituto de Biociências. Departamento de Ecologia.

Versão em português: 1. Lacuna ciência-prática 2. Comunicação de ciência 3. Tomada de decisão 4. Elaboração de políticas 5. Ecologia 6. Ciência da conservação I. Universidade de São Paulo. Instituto de Biociências. Departamento de Ecologia.

\section{Comissão Julgadora:}

Prof(a). Dr(a).

Prof(a). Dr(a).
Prof(a). Dr(a)

Profa. Dra. Renata Pardini

Orientadora 
No es mala la ciencia, es malo el uso que se hace de la ciencia no para servir a la vida, sino para servir al mercado. No es malo el conocimiento, no son malos los transgénicos, lo malo es que lo tengan las empresas y no el pueblo.

Pepe Mujica, $2^{a}$ Feira Nacional da Reforma Agrária

São Paulo, 6 de maio de 2017 


\section{AGRADECIMENTOS}

Agradeço a:

A Fundação de Amparo à Pesquisa do Estado de São Paulo (FAPESP, 2014/26182-0) pela bolsa de estudos que possibilitou a realização do meu curso de mestrado e a coleta de dados.

O "SCCS Miriam Rothschild Internship Programme" pelo apoio financeiro que viabilizou meu estágio na Universidade de Cambridge por um mês em abril de 2015.

A FAPESB - Fundação de Amparo à Pesquisa do Estado da Bahia e o CNPq - Conselho Nacional de Desenvolvimento Científico e Tecnológico pelo apoio financeiro ao projeto "Integrando Níveis de Organização em Modelos Ecológicos Preditivos" (INOMEP/PRONEX, PNX0016_2009) e ao CNPq novamente pelo apoio financeiro ao INCT em Estudos Interdisciplinares e Transdisciplinares em Ecologia e Evolução (INTREE, 465767/2014-1), no qual meu projeto se insere.

O Instituto de Biociências, Departamento de Ecologia e o programa de pós-graduação em Ecologia da Universidade de São Paulo pela disponibilização da infraestrutura para a realização deste trabalho. Especialmente a Vera e os membros da Comissão Coordenadora do Programa, por fazerem esse programa andar!

A minha orientadora, Renata Pardini, por todo apoio, ajuda, paciência, críticas, sugestões e direcionamentos ao longo deste projeto. Sua capacidade de encontrar lógica nas minhas ideias nebulosas é incrível e foi fundamental para a realização deste trabalho. Muito obrigada também pelas oportunidades para as quais você me apresentou e pelo companheirismo e amizade ao longo desses últimos anos!

Os membros do comitê de acompanhamento, Carla Morsello e Charbel Niño El-Hani, pelas críticas e sugestões que foram fundamentais em todas as etapas do projeto. Viva o trabalho em grupo, foi um imenso prazer trabalhar com vocês!

As pesquisadoras e pesquisadores do Conservation Science Group, da Universidade de Cambridge - Bill Sutherland, Lynn Dicks, Jessica Walsh, Nibedita Mukherjee, David Christian Rose e Rebecca Smith - por me receberem tão bem, ajudarem na discussão da metodologia e participarem nas atividades de sorting que foram fundamentais para o primeiro capítulo. 
Todos que me deram ideias, sugestões e críticas importantes para o primeiro capítulo, especialmente Tim Benton e dois revisores anônimos pelos comentários que melhoraram substancialmente o artigo, e Rafael Chaves e Victor Chaves pelas ideias e discussões iniciais.

Todas as entrevistadas e entrevistados, que me receberam com disponibilidade e interesse e possibilitaram a realização do segundo capítulo! E também à organização do congresso, que me cedeu um espaço e me deu todo o apoio logístico necessário para as entrevistas.

Victor Chaves, Patrícia Lopes, Juliana de Lucca, Paula Moraes, Gabriela Marin, Gustavo Requena, Adriana Martini, Rafael Raimundo, Cristiano Nogueira, Leandro Tambosi, Samanta Coutinho e Simone Campos, por participarem nas etapas piloto do sorting ou da metodologia Q e me ajudarem a melhorar essas metodologias! Obrigada mesmo pela disposição!

Patricia Ruggiero e Renata Orofino por me ajudarem no teste de reliability! Vocês foram incríveis e fofas em se disponibilizarem tão prontamente! Muito obrigada!

Todo mundo do DiCoM, sempre dispostos a ajudar e palpitar, mas também a dar uma descontraída com um cafezinho do meio da tarde!

Todas as amigas e amigos que fiz no Programa de Pós-Graduação em Ecologia, especialmente no Curso de Campo, no EcoEncontros e na Comissão Proex. Vocês fizeram o meu mestrado ser não apenas um grande aprendizado, mas também fonte de grandes alegrias e amizades!

A minha família, minha mãe, meu pai e meu irmão, por todo o apoio que sempre me deram e por continuamente me lembrarem que relaxar e descansar também é importante!

O Gabriel Kayano, por me acalmar nos momentos de estresse, por me ajudar nos momentos de necessidade, por discutir comigo o que eu precisasse discutir e por todo amor, apoio e carinho, sempre!

Obrigada! 


\section{TABLE OF CONTENTS}

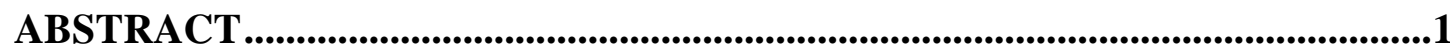

RESUMO ...............................................................................................................................2

INTRODUCTION...................................................................................................................

References ............................................................................................................................6

CHAPTER 1 - A CONCEPTUAL FRAMEWORK FOR UNDERSTANDING THE PERSPECTIVES ON THE CAUSES OF THE SCIENCE-PRACTICE GAP IN

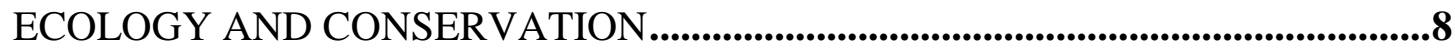

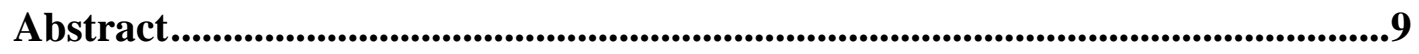

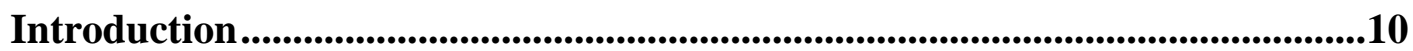

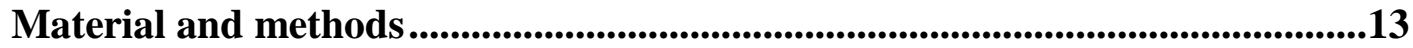

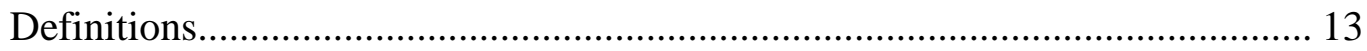

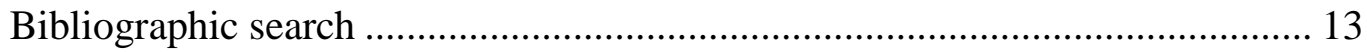

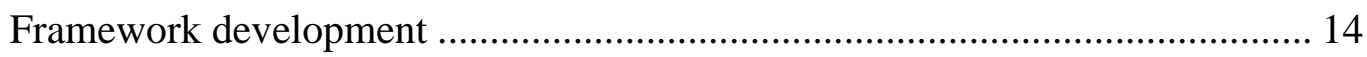

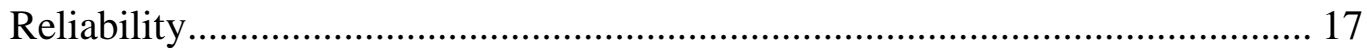

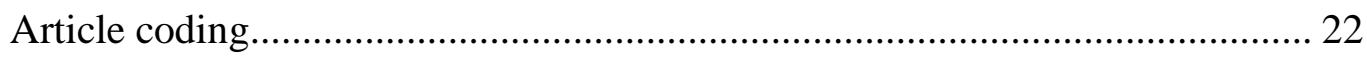

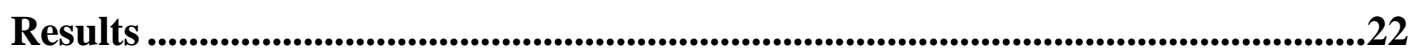

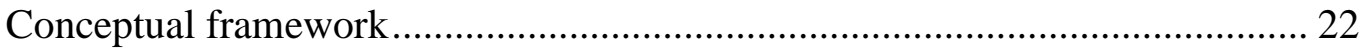

Predominance of perceived causes of the science-practice gap in the literature, over the years and across journals ............................................................... 29

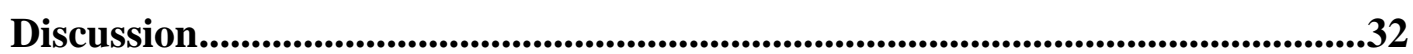

The perceived causes of the science-practice gap in Ecology and

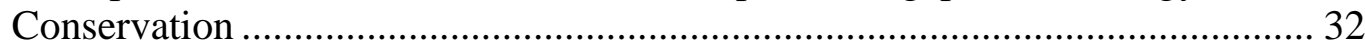

The perspectives of ecologists and conservation scientists on the science-

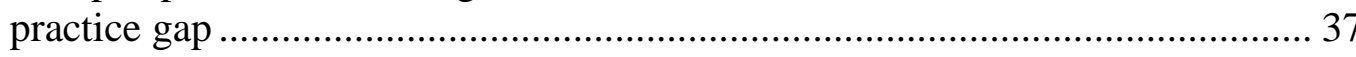

Putting into context the perspectives of ecologists and conservation scientists

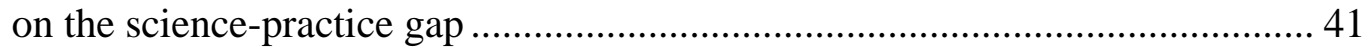

Implications for advancing the debate and fostering productive sciencepractice linkages in Ecology and Conservation ............................................... 45

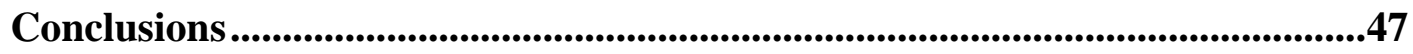

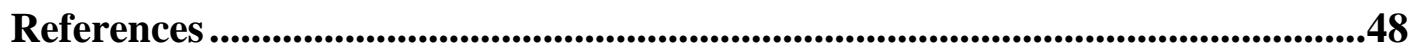

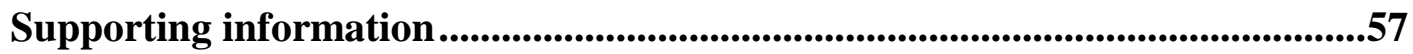

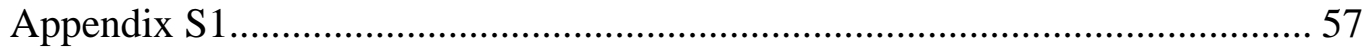

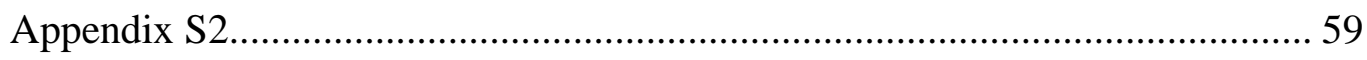

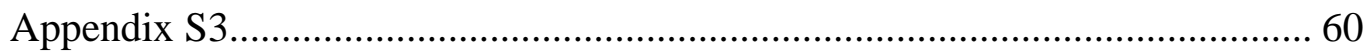




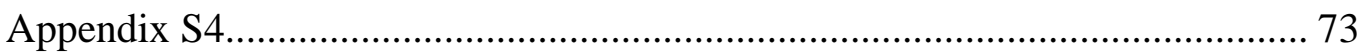

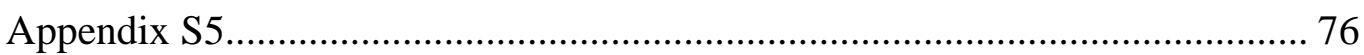

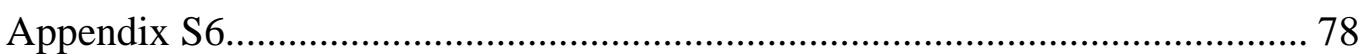

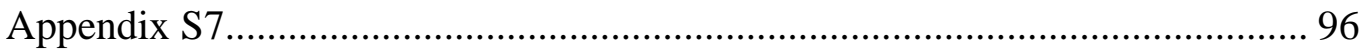

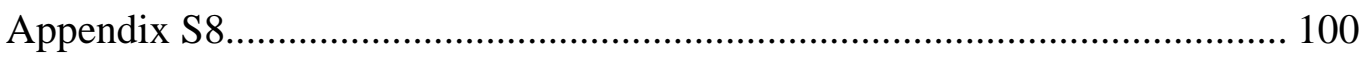

CHAPTER 2 - REVEALING PATTERNS OF SHARED THINKING ON THE SCIENCE-PRACTICE INTERFACE IN ECOLOGY AND CONSERVATION ....108

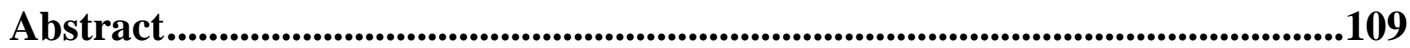

Introduction .............................................................................................................110

Material and methods.......................................................................................................112

Development of the set of statements (Q-set) .............................................. 113

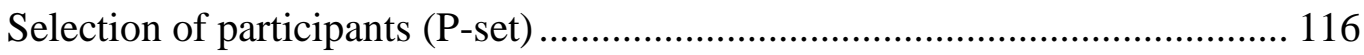

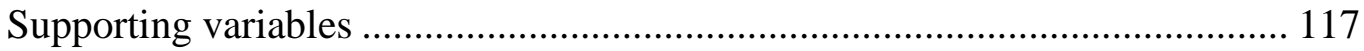

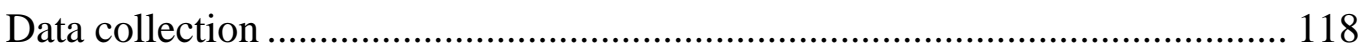

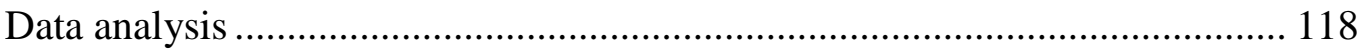

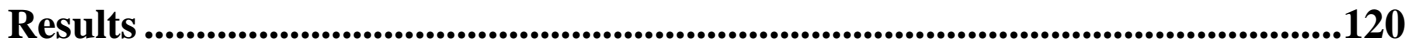

Participants associated with factor 1: Interactive Partners .............................. 124

Participants associated with factor 2: Interactive Technocrats ........................ 127

Participants associated with factor 3: Distant Producers ................................ 130

Main areas of disagreement across ways of thinking .................................... 132

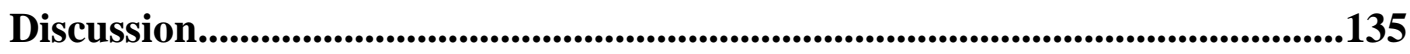

Ways of thinking about the science-practice interface in Ecology and

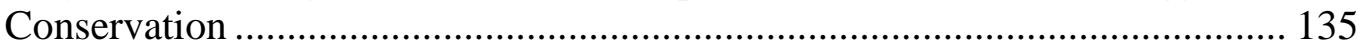

Directions for linking science and practice in Ecology and Conservation ....... 138

Conclusions ....................................................................................................................141

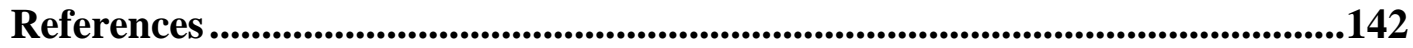

Supporting information ...........................................................................................148

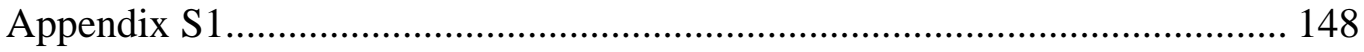

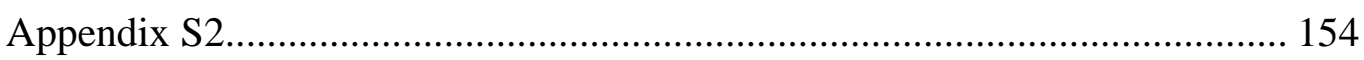

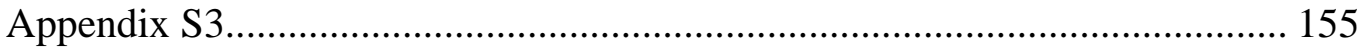

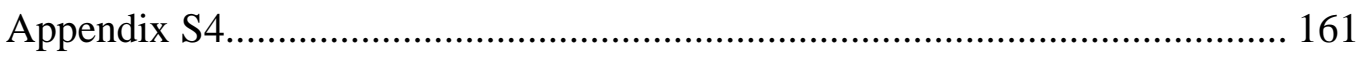

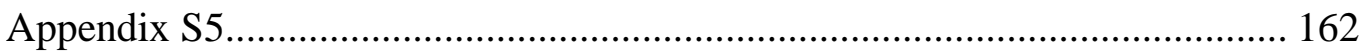

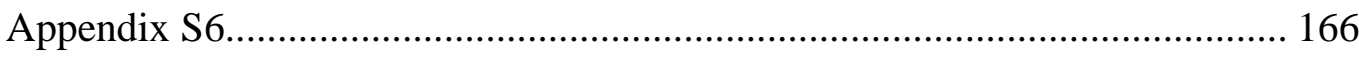

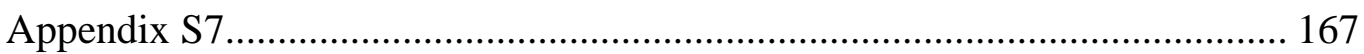

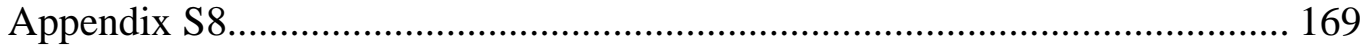

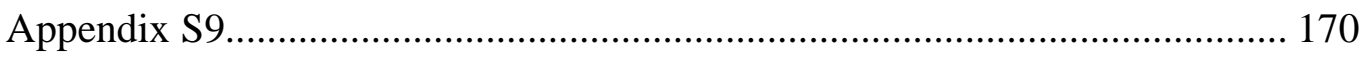

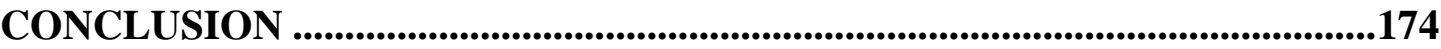




\section{ABSTRACT}

Many current debates in Ecology and Conservation Science center on how to navigate the interface between science, policy and practice with the aim of using science to support viable, effective solutions to environmental problems. This dissertation has the general aim of contributing to devise ways to navigate the science-practice interface by taking an interdisciplinary approach to identify (1) how the academic debate on this subject has been framed, and (2) how scientists and decision-makers have been thinking about the relationship between science and practice. In chapter 1, I present a literature review, based on 1563 sentences describing causes of the science-practice gap extracted from 122 articles published in Ecology and Biodiversity Conservation journals. I use text analysis techniques to organize these causes into a process-based conceptual framework that describes three perspectives on the important processes, knowledges and actors in the science-practice interface. I then evaluate the predominance of these perspectives over time and across journals, and assess them in light of disciplines studying the role of science in decision-making, such as Political Science. The unchanged predominance over time of the perspective centered on a linear, unidirectional flow of scientific knowledge from science to practice suggests debates in Ecology and Conservation lag behind trends in other disciplines towards perspectives focusing on a bidirectional, integrative flow of knowledges between science and practice. In Ecology and Conservation, the integrative perspective seems primarily restricted to research traditions historically isolated from mainstream Conservation Biology, which in turn has been dominated by "evidence-based conservation" approaches. All identified perspectives represent superficial views of decision-making by not accounting for limits to human rationality, complexity of decision-making contexts, fuzzy science-practice boundaries, ambiguity brought about by science, and different types of knowledge use. Nonetheless, the integrative perspective emphasizing collaborative work between scientists and decision-makers may potentially allow for more democratic decision-making processes and explicit discussions of values. In chapter 2, I focus on scientists and decision-makers from Brazil, a tropical developing nation with a growing science and rich biodiversity, but currently facing several drawbacks in environmental policies. I used the three perspectives of the conceptual framework of chapter 1 to create a list of 48 statements describing how the science-practice interface should ideally be. Using Q-methodology from psychology, I asked 22 ecologists and environmental federal analysts to rank their agreement with these statements. Principal component analysis revealed three groups of participants with similar rankings of statements, thus holding shared ways of thinking about the science-practice interface. All ways of thinking assigned great importance to actors and knowledges from both science and practice, but differed on the roles assigned to science, scientists or decision-makers, indicating the need to openly debate expected roles for each actor in science-practice partnerships. Moreover, such partnerships seem to be hindered by a lack of organizational incentive rather than by cultural differences between scientists and decision-makers. In the final session of the dissertation, I integrate the conclusions from both chapters, highlighting the most important implications for a better understanding of the science-practice interface and for fostering productive science-practice linkages in Ecology and Conservation. 


\section{RESUMO}

Diversos debates atuais em Ecologia e Ciência da Conservação estão centrados em como navegar na interface entre ciência e prática com o objetivo de usar a ciência para apoiar soluções efetivas e viáveis para os problemas ambientais. Esta dissertação tem como objetivo geral contribuir com caminhos para navegar na interface ciência-prática ao identificar, através de uma abordagem interdisciplinar, (1) como o debate acadêmico sobre este assunto tem sido feito e (2) como a relação entre ciência e prática é percebida por cientistas e tomadores de decisão. No capítulo 1, apresento uma revisão da literatura, conduzida a partir de 1563 frases sobre as causas da lacuna ciência-prática extraídas de 122 artigos publicados em periódicos de Ecologia e Conservação da Biodiversidade. Uso técnicas de análise de texto para organizar essas causas em um esquema conceitual que descreve três perspectivas sobre os processos, conhecimentos e atores importantes na interface ciência-prática. A seguir, averiguo a predominância dessas perspectivas ao longo do tempo e em diferentes periódicos, para depois avaliar as perspectivas à luz de disciplinas que estudam o papel da ciência na tomada de decisão, como a Ciência Política. A predominância ao longo do tempo da perspectiva centrada em um fluxo unidirecional de conhecimento da ciência para a prática sugere que o debate em Ecologia e Conservação não seguiu a tendência observada em outras disciplinas na direção de perspectivas enfatizando um fluxo bidirecional e integrativo de conhecimentos entre a ciência e a prática. Em Ecologia e Conservação, a perspectiva integrativa parece estar restrita a tradições de pesquisa historicamente isoladas da Biologia da Conservação, que, por sua vez, é dominada por abordagens de "conservação baseada em evidência". Todas as perspectivas constatadas representam visões superficiais da tomada de decisão ao desconsiderarem limites à racionalidade humana, a complexidade da tomada de decisão, fronteiras difusas entre ciência e prática, a ambiguidade trazida pela ciência e diferentes tipos de uso de conhecimento. Por outro lado, a perspectiva integrativa que enfatiza o trabalho colaborativo entre cientistas e tomadores de decisão permite potencialmente processos de tomada de decisão mais democráticos e discussões explícitas de valores. No capítulo 2, eu me volto para cientistas e tomadores de decisão do Brasil, um país tropical em desenvolvimento com uma ciência crescente e uma rica biodiversidade, mas cujas políticas ambientais vem sofrendo diversas ameaças. A partir das três perspectivas do esquema conceitual do capítulo 1, elaborei uma lista de 48 frases descrevendo como a interface entre ciência e prática deveria ser. Usando a metodologia $Q$ advinda da Psicologia, pedi para 22 ecólogos e analistas ambientais do IBAMA ranquearem suas concordâncias com essas frases. Uma análise de componentes principais revelou três grupos de participantes com ranqueamentos similares, apresentando, portanto, modos de pensar compartilhados sobre a interface ciência-prática. Todas as formas de pensar conferiram grande importância para atores e conhecimentos da ciência e da prática, mas houve divergência nos papéis atribuídos à ciência, aos cientistas e aos tomadores de decisão, indicando a necessidade de debater abertamente os papéis que se espera que cada ator assuma nas parcerias entre ciência e prática. Além disso, a falta de estímulo organizacional parece ser um entrave maior para essas parcerias do que diferenças culturais entre cientistas e tomadores de decisão. Na última sessão da dissertação, eu integro as conclusões dos dois capítulos, ressaltando as implicações mais importantes para uma melhor compreensão da interface ciência-prática e para o fomento de parcerias produtivas entre ciência e prática em Ecologia e Conservação. 


\section{INTRODUCTION}

Prompted by increased recognition of human impacts on the environment, Conservation Biology began to form during the 1960s, establishing itself as a scientific discipline in the 1980s (Meine, Soule, \& Noss, 2006). Defined from the beginning as a mission-driven, crisis discipline aiming "to provide principles and tools for preserving biological diversity" (Soulé, 1985, p. 727), Conservation Biology encompassed a value-laden ethical dimension, recognizing intrinsic value in biodiversity (Soulé, 1985; Meine et al., 2006). As a problem-solving discipline, Conservation Biology involved new multidisciplinary connections across ecological sub-disciplines such as wildlife ecology, natural history and theoretical ecology but also across other natural sciences such as genetics, veterinary sciences and physiology (Soulé, 1985).

Since its genesis in the 1960s, Conservation Biology has undergone many shifts in framings and purpose (Mace, 2014). In the beginning, conservation biologists focused on the preservation of pristine natural habitats separated from human influence (Mace, 2014). However, in the following years, recognition of how social systems affect and are affected by ecological systems arose. In the 1970s and 1980s, efforts were directed to reduce human threats to species and ecosystems, whereas by the late 1990s the focus had shifted to "providing sustainable benefits for people in the form of ecosystem goods and services" (Mace, 2014, p. 1558). Recently, the discipline has moved away from this more utilitarian view of nature to an emphasis on the complex, dynamic, two-way relationships between ecological systems and human societies (Mace, 2014). By including social systems, the scope of Conservation Biology has broadened to an interdisciplinary field - Conservation Science -, expanding beyond biological sciences and embracing disciplines such as economics, political sciences, anthropology, psychology and sociology (Kareiva \& Marvier, 2012).

Conservation Science, however, has retained its mission-driven orientation (Kareiva \& Marvier, 2012). While ecologists and conservation scientists recognized the importance of interdisciplinary work, difficulties to apply scientific knowledge to real-world problems became a major concern. Ecologists and conservation scientists were criticized for focusing on research questions irrelevant to decision-makers (e.g., Linklater, 2003; Esler et al., 2010) and for not supporting the development of viable, 
effective solutions to aggravating environmental problems (Whitten, Holmes, \& MacKinnon, 2001). In turn, conservation practitioners were shown to seldom rely on scientific evidence to support their decisions (Pullin et al., 2004; Pullin \& Knight, 2005). The recognition of these problems evolved into an acknowledgement of a science-practice or research-implementation gap in Ecology and Conservation (Knight et al., 2008; Barmuta, Linke, \& Turak, 2011; Habel et al., 2013). Although criticized for implying a linear framing of science communication (Adams \& Sandbrook, 2013; Toomey, Knight, \& Barlow, 2016), the science-practice gap remains a widely acknowledged problem hampering conservation efforts worldwide, and particularly in Brazil (e.g., Pardini et al., 2013). Important ecological journals have dedicated special sections to the barriers, challenges and opportunities for narrowing the gap between science and practice (e.g., Biotropica, in 2009, and Journal of Applied Ecology, in 2014). Thus, at the heart of many current scientific debates in Ecology and Conservation Science is how to effectively navigate the intersection between ecological and conservation science, policy and practice.

This dissertation intends to contribute to devise ways to navigate the interface between science and decision-making in Ecology and Conservation by taking an interdisciplinary approach to (1) conceptually organize the distinct perspectives on the causes of the science-practice gap found in the literature, and (2) identify shared ways of thinking among scientists and decision-makers. I first review the ecological and conservation literature on the causes of the science-practice gap, organizing them into a conceptual framework that identifies three perspectives on the important processes linking science and practice. Then, I use this framework to investigate how scientists and decision-makers in Brazil think about the science-practice interface. Throughout this work, I rely on methodological tools from the social sciences and bring theoretical contributions from disciplines directly studying decision-making and the role of science in decision-making, such as Science, Technology and Society (STS) studies and Political Science. By enlightening how the academic debate has been framed and how people have been thinking about the science-practice interface, I then derive some implications for a more effective dialogue among scientists and decision-makers in Ecology and Conservation.

The dissertation is divided into two chapters and a final session on the main conclusions, briefly outlined below: 
- Chapter 1, entitled "A conceptual framework for understanding the perspectives on the causes of the science-practice gap in Ecology and Conservation", is a paper submitted, and accepted pending major revisions, in Biological Reviews presenting the results of the literature review. I base the review on 1563 sentences describing causes of the science-practice gap extracted from 122 articles published in Ecology and Biodiversity Conservation journals, and use text analysis techniques to organize these causes into a process-based conceptual framework that describes three perspectives on the important processes, knowledges and actors in the science-practice interface. I then evaluate the predominance of these perspectives over time and across journals, and assess them in light of disciplines studying the role of science in decision-making, such as STS studies and Political Science. This chapter takes a broad, international look on how the science-practice interface has been debated within the ecological and conservation fields, pointing out topics ecologists and conservation scientists have ignored or addressed superficially and topics complementing the debate in the political sciences.

- In Chapter 2, entitled "Revealing patterns of shared thinking on the sciencepractice interface in Ecology and Conservation", I present the results on the shared ways of thinking about the science-practice interface in Ecology and Conservation. To counterpart the first chapter, I investigate a particular case, focusing on scientists and decision-makers in Brazil, a tropical developing nation with a growing science and rich biodiversity, but currently facing several drawbacks in environmental policies. I use the conceptual framework developed in Chapter 1, and the three identified perspectives on the important processes, knowledges and actors in the science-practice interface, to create a list of 48 statements describing how the science-practice interface should ideally be. Using Q-methodology from psychology, I asked 22 ecologists and environmental federal analysts in Brazil to rank their agreement with each statement. From principal component analysis, I identify three groups of participants with similar rankings of statements, thus holding shared ways of thinking about the sciencepractice interface. I then speculate on possible reasons underlying the arise of each shared viewpoint, and discuss disagreements and points of consensus across the three ways of thinking to enlighten how to deal with possible conflicts and 
reveal paths for a more effective dialogue between scientists and decisionmakers.

- Finally, in the session Conclusion, I summarize and interconnect the main findings of both chapters, pointing out the most important implications for a better understanding of the science-practice interface and for fostering productive science-practice linkages in Ecology and Conservation.

\section{REFERENCES}

ADAMS, W.M. \& SANDBRooK, C. (2013) Conservation, evidence and policy. Oryx 47, $329-335$.

BARMUTA, L.A., LinKe, S. \& TURAK, E. (2011) Bridging the gap between 'planning' and 'doing' for biodiversity conservation in freshwaters. Freshwater Biology 56, 180-195.

Esler, K.J., Prozesky, H., Sharma, G.P. \& McGeoch, M. (2010) How wide is the 'knowing-doing' gap in invasion biology? Biological Invasions 12, 4065-4075.

Habel, J.C., Gossner, M.M., Meyer, S.T., EgGermont, H., Lens, L., Dengler, J. \& WEISSER, W.W. (2013) Mind the gaps when using science to address conservation concerns. Biodiversity and Conservation 22, 2413-2427.

KAREIVA, P. \& MARVIER, M. (2012) What is conservation science? BioScience 62, 962-969.

Knight, A.T., Cowling, R.M., Rouget, M., Balmford, A., Lombard, A.T. \& CAMPBELL, B.M. (2008) Knowing but not doing: Selecting priority conservation areas and the research-implementation gap. Conservation Biology 22, 610-617.

LiNKLATER, W.L. (2003) Science and management in a conservation crisis: A case study with rhinoceros. Conservation Biology 17, 968-975.

MACE, G.M. (2014) Whose conservation? Science 345, 1558-1560.

Meine, C., Soule, M. \& Noss, R.F. (2006) 'A mission-driven discipline': the growth of conservation biology. Conservation Biology 20, 631-651.

Pardini, R., Rocha, P.L.B., El-Hani, C. \& Pardini, F. (2013) Challenges and opportunities for bridging the research-implementation gap in ecological science and management in Brazil. In Conservation Biology: Voices from the Tropics pp. 77-95.

PULLIN, A.S. \& KNIGHT, T.M. (2005) Assessing conservation management's evidence base: a survey of management-plan compilers in the United Kingdom and Australia. Conservation Biology 19, 1989-1996.

Pullin, A.S., Knight, T.M., Stone, D.A. \& Charman, K. (2004) Do conservation managers use scientific evidence to support their decision-making? Biological Conservation 119, 245-252. 
SOULÉ, M.E. (1985) What is conservation biology? BioScience 35, 727-734.

ToOMEY, A.H., KNIGHT, A.T. \& BARLOW, J. (2016) Navigating the space between research and implementation in conservation. Conservation Letters.

Whitten, T., Holmes, D. \& MacKinnon, K. (2001) Conservation biology: a displacement behavior for academia? Conservation Biology 15, 1-3. 


\section{CHAPTER 1}

A conceptual framework for understanding the perspectives on the causes of the science-practice gap in Ecology and Conservation

Diana B. Garcia, Carla Morsello, Charbel N. El-Hani, Renata Pardini The content of this chapter was submitted in 08/12/2016 to Biological Reviews, accepted pending major revisions in 01/04/2017 and resubmitted in 05/26/2017

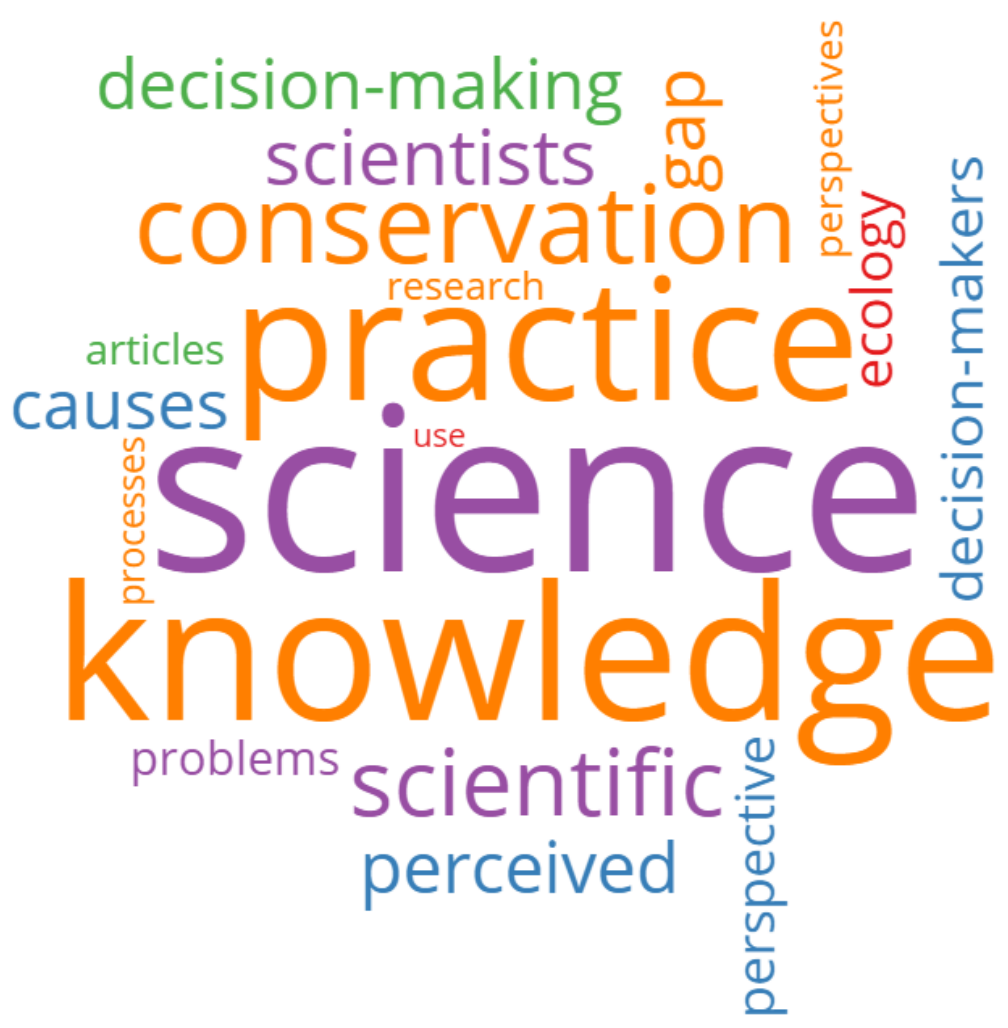




\section{ABSTRACT}

Applying scientific knowledge to confront societal challenges is a difficult task, an issue known as the science-practice gap. In Ecology and Conservation, scientific evidence has been seldom used in decision-making, despite the calls for an increasing role of ecological science in developing solutions for a sustainable future. To date, multiple causes of the science-practice gap and diverse approaches to link science and practice in Ecology and Conservation have been proposed. To foster a transparent debate and broaden our understanding of the difficulties of using scientific knowledge, we reviewed the perceived causes of the science-practice gap, aiming at: (1) identifying the perspectives of ecologists and conservation scientists on the problem, (2) evaluating the predominance of these perspectives over time and across journals, and (3) assessing them in light of disciplines studying the role of science in decision-making (e.g., Political Science). We based our review on 1563 sentences describing causes of the sciencepractice gap extracted from 122 articles and on discussions with eight scientists on how to classify these sentences. The resulting process-based framework describes three perspectives on the important knowledges and actors in the science-practice interface, identifying, for each perspective, the processes linking science and practice. The most common perspective assumes only scientific knowledge should support practice, perceiving a linear flow of knowledge from science to practice and recognizing flaws in knowledge generation, communication, and/or use. The second assumes both scientists and decision-makers should contribute with knowledge to support practice via knowledge integration, which, for several reasons, is perceived to infrequently occur. The last perspective was very rare, and assumes scientists should put their results into practice, but they rarely do. Some causes (e.g., cultural differences between scientists and decision-makers) are shared with other disciplines, while others seem specific to Ecology and Conservation (e.g., inadequate research scales), but all of them require one of three general types of solutions. The unchanged predominance of the linear perspective over time may be associated with the success of evidence-based conservation and suggests debates in Ecology and Conservation lag behind trends in other disciplines towards integrative views ascribing larger roles to decision-makers. In turn, the integrative perspective seems primarily restricted to research traditions historically isolated from mainstream conservation biology. The perspectives represented superficial views of decision-making by not accounting for limits to human rationality, complexity of 
decision-making contexts, fuzzy science-practice boundaries, ambiguity brought about by science, and different types of knowledge use. However, the integrative perspective can potentially allow for democratic decision-making processes, explicit discussions of values and multiple types of science use. Disciplines such as Political Science, by addressing decision-making processes mainly at national and federal levels, can complement ecologists and conservation scientists' focus on knowledge generation and communication/integration directed mostly at local issues. To broaden our understanding of the interface and foster productive science-practice linkages, we argue for interdisciplinarity across Ecology, Conservation and Political Science in both research and education.

\section{KEYWORDS}

Environmental policy; environmental management; research-implementation gap; knowing-doing gap; policy-making; science communication; transdisciplinarity; communities of practice, science, technology and society; bounded rationality.

\section{INTRODUCTION}

People throughout the world believe science has often brought positive impacts to society and can help confront many present-day issues (e.g., improving healthcare or adapting to climate change) (Eurobarometer, 2014; Laplane et al., 2015). However, despite public confidence in science, applying scientific knowledge to solve real-world problems and support decision-making is a difficult task. In many fields, such as healthcare (Bero et al., 1998) and education (Anderson, 2007), this disconnection between science and practice has been termed the science-practice, researchimplementation, research-practice or knowing-doing gap.

In Ecology and Conservation, the debate regarding the use of scientific knowledge in decision-making has intensified concurrently with the aggravation of environmental problems. The worldwide increase in human wellbeing has taken place at the cost of important regulating and supporting services as well as biodiversity (MEA, 2005; Butchart et al., 2010). In the long run, these changes may impair human livelihoods (Foley et al., 2005), and, as argued by some, lead to a global state shift in the Earth's biosphere (Barnosky et al., 2012). Facing these pressing challenges, several scientists 
have called for an increasing role of ecological and conservation science in developing solutions for a sustainable future (Carpenter \& Folke, 2006; Burger et al., 2012).

Several studies have shown, however, that scientific evidence in Ecology and Conservation is seldom directly used to support decision-making (Sutherland \& Pullin, 2004; Pullin et al., 2004; Pullin \& Knight, 2005; Cook et al., 2012), while others reported a disconnection between research questions and information required by decision-makers (Linklater, 2003; Esler et al., 2010). Hence, many authors have argued for the existence of a science-practice gap (e.g., Knight et al., 2008; Esler et al., 2010; Barmuta, Linke, \& Turak, et al., 2011; Cabin et al., 2010), and important ecological journals have dedicated special sections to the barriers, challenges and opportunities for narrowing this gap (e.g., Biotropica, in 2009, and Journal of Applied Ecology, in 2014).

To bridge the gap, many ecologists and conservation scientists have called for evidence-based or evidence-informed conservation practices (Pullin \& Knight, 2003; Sutherland \& Pullin, 2004; Haddaway \& Pullin, 2013). Others have emphasized knowledge co-production between scientists and decision-makers (e.g., Shackleton, Cundill, \& Knight, 2009; Hegger et al., 2012; Aldunce et al., 2016), but these propositions have generally been neglected in mainstream conservation biology (Curtin \& Parker, 2014). Recently, the "science-practice gap" term and the prevalence of the evidence-based approach have been criticized for assuming linearity in science communication, overlooking other knowledge types and the intricate processes of decision-making (Adams \& Sandbrook, 2013; Toomey, Knight, \& Barlow, 2016).

Understanding the distinct perspectives on the science-practice interface within this heterogeneity of arguments can increase transparency, revealing diversity, conflicts and synergies of ideas. Such transparency can foster a more effective debate that connects isolated propositions and avoids dominance of single models or solutions (Carpenter et $a l ., 2009)$. Because perspectives on a given problem are typically associated with causal narratives (e.g., Mattson et al., 2006), synthesizing and organizing the perceived causes of the science-practice gap into common conceptual domains can assist in this endeavor. To date, however, these causes are scattered in the literature, including varied aspects such as practitioners' lack of access to scientific journals (Sunderland et al., 2009), academic reward systems focused on number of publications (Shanley \& López, 2009), or a unidirectional flow of knowledge from science to practice (Shackleton et al., 2009; Pardini et al., 2013). 
Synthesizing the perceived causes of the science-practice gap into common conceptual domains can also provide a structure for assessing the perspectives of ecologists and conservation scientists in light of disciplines addressing the role of science in decision-making and its relation to society, e.g., Science, Technology and Society (STS) studies and Political Science. The debate on the science-practice gap in Ecology and Conservation has apparently overlooked ideas and conceptualizations from these disciplines (Cairney, 2016), while political scientists have been criticized for giving little attention to decision-making concerning environmental and conservation issues (Agrawal \& Ostrom, 2006). STS studies and Political Science focus on decision-making processes, highlighting decision-making contexts are complex and entail political interests and social values besides scientific evidence (Albaek, 1995). They also argue science can be used in diverse ways, both directly to solve specific problems and indirectly to influence decision-makers' thinking (Weiss, 1979). Embracing these oftenneglected aspects of decision-making can greatly broaden our understanding on the difficulties of using scientific knowledge to support decisions, and thus our ability to envision solutions. It may also encourage scientists to reflect on their ideas and practices, and help highlight paths for advancing the study of the science-practice interface and for a more productive use of science in decision-making.

In this paper, we draw on an extensive search of the scientific literature in Ecology and Conservation and qualitative text analysis techniques to organize the perceived causes of the science-practice gap into a conceptual framework, aiming at identifying the perspectives of ecologists and conservation scientists on the problem. We then evaluate if the predominance of these perspectives changed over time and across journals with distinct research traditions. We discuss the findings in the light of disciplines devoted to understand the role of science in decision-making and its relation to society, pointing out the topics ecologists and conservation scientists have ignored or addressed superficially and topics complementing the debate in the political sciences. 


\section{MATERIAL AND METHODS}

\section{Definitions}

We adopted the expression "science-practice gap" (e.g., Cabin et al., 2010), adapting to the ecological and conservation context the definitions presented in Broekkamp \& Hout-Wolters (2007) for Education. We thus consider "ecological and conservation science" as the structures, processes, products, and people directly involved in the systematic production of knowledge in Ecology and Conservation within academia. "Ecological and conservation practice", in turn, is defined as the structures, processes, products, and people directly involved in action and decision-making in public, private and non-profit organizations responsible for the development of environmental policies and/or the conservation or management of biodiversity and of ecological and socioecological systems. As defined here, the science-practice gap encompasses the distance between scientific and practical knowledge, between research and decisionmaking/practical actions, and between organizations and/or people involved in science and practice (thereafter "scientists" and "decision-makers").

\section{Bibliographic search}

We searched the "Web of Science Core Collection" for articles published since 1900 in journals or proceedings categorized in Ecology or Biodiversity Conservation, encompassing the majority of journals where ecologists and conservation scientists publish (Appendix S1). We searched for articles including different expressions for the “science-practice gap" (e.g., "research-implementation gap", "knowing-doing gap") and related sentences (e.g., "gap between research and implementation", "linking science and practice"). Three groups of synonymous terms - related to "science", to "practice" and to "gap" or "bridge"- were searched within the title, abstract or keywords of articles. At least one term from each group had to be at most five words from at least one term of each of the other two groups (Appendix S2). Alternatively, articles could include only the word "transdisciplinarity", frequently adopted to define the integration between practical and scientific knowledge (Tress, Tress \& Fry, 2005; Reyers et al., 2010). The final search was conducted in December 2014 and returned 1524 articles.

We screened the articles by reading the title and abstract and, in case of indecision about appropriateness, the main text (Fig. 1). We selected 122 articles (Appendix S3) that 
were accessible and discussed factors causing a divide between science and practice in Ecology and Conservation, even if this was not the paper's main objective (Appendix S1). The first author (DBG) selected 77 priority articles whose explicit objective was to discuss the causes of the science-practice gap or were published in special sections on the topic. The priority articles served to develop a first version of the framework, but all 122 articles were used for the final conceptual framework (Fig. 1).

\section{Framework development}

The conceptual framework was developed using an inductive approach, based on the similarities between the sentences referring to causes of the science-practice gap in Ecology and Conservation within the selected articles. We used the text analysis technique cutting and sorting, which involves identifying sentences or expressions related to the research question, printing them into separated pieces of paper (cutting) and arranging them by perceived similarity (sorting) (Bernard \& Ryan, 2010). Each pile is named and the inclusion criteria described, representing recurrent themes or categories. Such text analysis techniques are adequate for finding regularities in written data (Bradley, Curry \& Devers, 2007; Bernard \& Ryan, 2010), helping to identify common domains while valuing the original ideas as expressed by the authors.

During the cutting, we identified, within the set of priority articles, 1057 sentences referring to causes of the science-practice gap (Fig. 1), including only those for which the causal connection was comprehensible from the sentence itself or including a context of three to four lines before and/or after the sentence. Selected sentences encompassed causes perceived either by the authors of the paper or by interviewees or respondents, in case the paper assessed opinions (e.g., of scientists and/or decision-makers). 

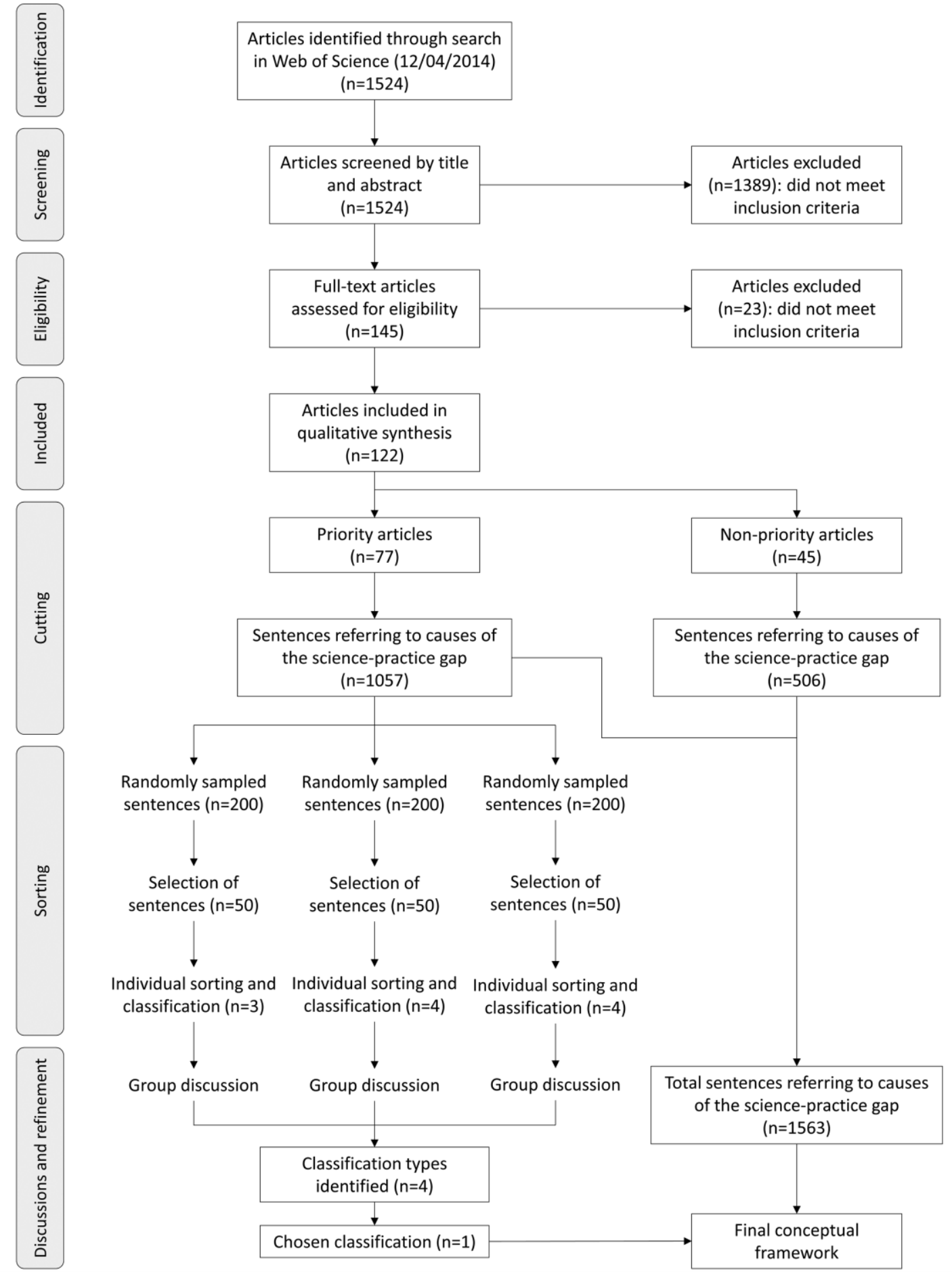

Figure 1. Flow diagram of the procedures used for searching and selecting articles and for developing the conceptual framework of perceived causes of the science-practice gap in Ecology and Conservation. 
To encompass different ways of thinking, the sorting was independently conducted by eight scientists whose research involves the science-practice interface (including the authors), organized in three groups (Fig. 1, Appendix S4). For each group, we randomly sampled a different set of 200 sentences taken from the 1057 set, and then reduced it to a subset of 50 sentences by choosing those that represented the diversity of perceived causes present in the initial set of 200 sentences (i.e., avoiding too many sentences referring to a similar cause). This process resulted in three sets of 50 sentences (one for each group). Each scientist sorted the 50 sentences into piles by perceived similarity, named them and described the inclusion criteria, thus producing an independent classification of perceived causes of the science-practice gap in Ecology and Conservation. After this individual sorting, each group met personally to discuss the differences, advantages and disadvantages between the classifications.

As a result, eight classifications were obtained, which we later grouped into four distinct types based on the discussed similarities concerning the underlying logic: organized by components, by processes, by personal opinion or with no explicit organization base (Appendix S4). The first two classifications refer to the same logic of understanding the science-practice interface as a system (e.g., CHSRF, 2000), but one focus on the different components of the system - scientists, decision-makers, different forms of knowledge, while the other focus on the processes - production, dissemination, exchange, use, application - that interlink system components.

Based on the group discussions, we first listed the advantages and disadvantages of the four classification types (Appendix S4) and then created the following criteria we considered desirable for the final conceptual framework: (1) present a clear underlying logical structure; (2) present mutually exclusive categories; and (3) allow the identification of different perspectives on the science-practice gap. Both the components and process-based classifications fulfilled the first two criteria. However, while components are an important part of any system description, they can be linked in diverse ways by different processes, resulting in distinct conceptions of the system. Thus, a more thorough description of the perspectives for linking science and practice depends upon untangling the processes perceived to be involved, which were made explicit only in the classification based on processes. We thus chose the process-based classification.

The chosen classification was then refined in two steps. First, we reorganized categories and created new ones aiming at eliminating the debated disadvantages. For 
example, as the chosen classification did not include perceived causes associated with personal and cultural characteristics of scientists and decision-makers (Appendix S4), we created such a category. Then, all 1563 sentences on causes of the science-practice gap from all articles (including the 45 non-priority ones) were allocated into the classification categories by one of the authors (DBG). When one sentence did not fit the categories, we modified the categories and/or criteria, without altering the underlying logic, to assure the final conceptual framework was representative of the entire set of sentences referring to causes of the science-practice gap from all articles. The final conceptual framework encompassed 48 categories of perceived causes of the science-practice gap organized into four hierarchical levels (Table 1).

\section{Reliability}

We estimated the conceptual framework reliability through the pairwise agreement between one author (DGB) and two outside evaluators in the allocation of sentences into the framework categories (Appendix S5). Each evaluator allocated a different set of 150 sentences ( $\sim 10 \%$ of the total) taken from all 48 categories (Table 1$)$ : one set encompassed only sentences expressing explicitly and precisely the perceived causes of the gap, while the other included sentences taken randomly from each category. The interrater pairwise agreement was calculated, for each of the four hierarchical levels of the framework, by correcting the observed author-evaluator agreement by the agreement expected by chance, estimated via simulations (Appendix S5). The resulting coefficient varies from 0 (observed agreement equal to expected by chance) to 1 (perfect agreement), with values greater than 0.67 accepted as reliable (Krippendorff, 2004). 
Table 1. Simplified version of the conceptual framework of perceived causes of the science-practice gap in Ecology and Conservation found in the scientific literature. The complete version of the framework includes, besides the categories presented here, a category of "other causes" in every hierarchical level (Appendix S6). Detailed criteria for all categories and examples of original sentences are also in Appendix S6. N = Number of articles containing sentences related to each category.

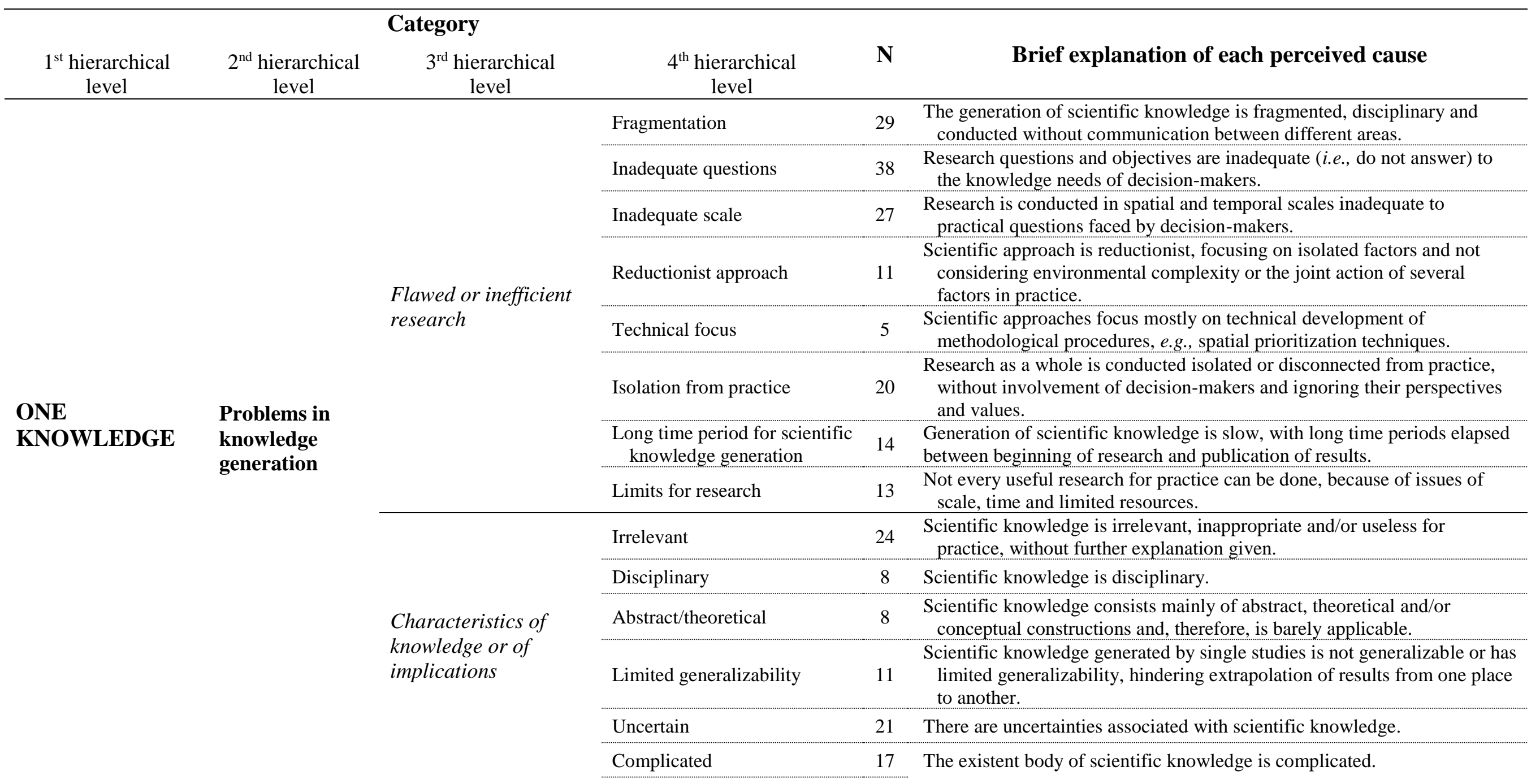




\section{Category}

$1^{\text {st }}$ hierarchical level $2^{\text {nd }}$ hierarchical level $3^{\text {rd }}$ hierarchical level $4^{\text {th }}$ hierarchical level

\section{Brief explanation of each perceived cause}

\begin{tabular}{|c|c|c|c|c|}
\hline & & Controversial & 23 & $\begin{array}{l}\text { Scientific knowledge is controversial, with often contradictory results that } \\
\text { can change over time and lack of consensus regarding practical } \\
\text { recommendations. }\end{array}$ \\
\hline & & Unreliable & 4 & $\begin{array}{l}\text { Scientific knowledge generated by particular studies is unreliable or of } \\
\text { poor quality, being generated without scientific rigor. }\end{array}$ \\
\hline & & Inadequate implications & 19 & $\begin{array}{l}\text { Recommendations, tools and practical protocols proposed by scientists are } \\
\text { inadequate given practical restrictions of time, space and resources. }\end{array}$ \\
\hline & \multirow[b]{2}{*}{ Knowledge gaps } & Lack of knowledge & 28 & $\begin{array}{l}\text { Scientific knowledge regarding questions that are relevant in practice is } \\
\text { lacking. }\end{array}$ \\
\hline & & Lack of implications & 22 & $\begin{array}{l}\text { Recommendations, tools and/or practical protocols regarding questions that } \\
\text { are relevant are lacking. }\end{array}$ \\
\hline \multirow{5}{*}{$\begin{array}{l}\text { Problems in } \\
\text { knowledge } \\
\text { communication }\end{array}$} & \multirow{2}{*}{$\begin{array}{l}\text { Problems in } \\
\text { knowledge transfer by } \\
\text { scientists }\end{array}$} & Limited availability & 25 & $\begin{array}{l}\text { Scientists do not make scientific knowledge available for decision-makers, } \\
\text { either because scientific journals are restricted to academia, because } \\
\text { scientists do not look for other means of communication or because there } \\
\text { is no dissemination of results. }\end{array}$ \\
\hline & & Inadequate translation & 50 & $\begin{array}{l}\text { Scientific knowledge is translated into inadequate formats, tools or } \\
\text { languages or in a distorted way to decision-makers. }\end{array}$ \\
\hline & \multirow{2}{*}{$\begin{array}{l}\text { Problems in } \\
\text { knowledge reception } \\
\text { by decision-makers }\end{array}$} & Lack of access & 37 & $\begin{array}{l}\text { Scientific knowledge is not accessed by decision-makers, either because } \\
\text { access is difficult for them or because decision-makers do not concern } \\
\text { themselves with accessing scientific knowledge. }\end{array}$ \\
\hline & & Difficulty in understanding & 37 & $\begin{array}{l}\text { Scientific knowledge is not understood or critically analyzed by decision- } \\
\text { makers, is incorrectly understood or is difficult to understand. }\end{array}$ \\
\hline & $\begin{array}{l}\text { Problems in } \\
\text { communication } \\
\text { as a whole }\end{array}$ & & 6 & $\begin{array}{l}\text { Flaws, errors or inefficiencies affect communication of scientific } \\
\text { knowledge as a whole, including high costs in terms of time and } \\
\text { resources involved in communicating this knowledge. }\end{array}$ \\
\hline \multirow{2}{*}{$\begin{array}{l}\text { Problems in } \\
\text { knowledge use }\end{array}$} & \multirow{2}{*}{$\begin{array}{l}\text { Knowledge } \\
\text { disregarded }\end{array}$} & Rejection by decision-makers & 26 & $\begin{array}{l}\text { Decision-makers reject the use of scientific knowledge in practice, either } \\
\text { because they have negative beliefs and attitudes towards science, } \\
\text { preferring to use their personal experiences, or because they do not trust } \\
\text { the knowledge source. }\end{array}$ \\
\hline & & $\begin{array}{l}\text { Impediment by the } \\
\text { organizational and/or } \\
\text { institutional structure }\end{array}$ & 23 & $\begin{array}{l}\text { Structures of practice force decision-makers to disregard scientific } \\
\text { knowledge, because of legislative factors, bureaucratic mechanisms or } \\
\text { lack of time in day-to-day activities to use scientific knowledge. }\end{array}$ \\
\hline
\end{tabular}




\begin{tabular}{|c|c|c|c|c|c|}
\hline \multicolumn{6}{|c|}{ Category } \\
\hline $\begin{array}{l}1^{\text {st }} \text { hierarchical } \\
\text { level }\end{array}$ & $\begin{array}{l}2^{\text {nd }} \text { hierarchical } \\
\text { level }\end{array}$ & $\begin{array}{l}3^{\text {rd }} \text { hierarchical } \\
\text { level }\end{array}$ & $\begin{array}{l}4^{\text {th }} \text { hierarchical } \\
\text { level }\end{array}$ & $\mathbf{N}$ & Brief explanation of each perceived cause \\
\hline & & \multicolumn{2}{|l|}{ Knowledge selected } & 11 & $\begin{array}{l}\text { Scientific knowledge reaching practice is selected and misused or partially } \\
\text { used to support interests of decision-makers. }\end{array}$ \\
\hline & & \multicolumn{2}{|l|}{$\begin{array}{l}\text { Knowledge } \\
\text { outweighed }\end{array}$} & 28 & $\begin{array}{l}\text { Political and economic interests or values and beliefs of social groups } \\
\text { involved outweigh scientific knowledge in practice. }\end{array}$ \\
\hline & \multirow{2}{*}{$\begin{array}{l}\text { Problems in the } \\
\text { feedback from } \\
\text { practice }\end{array}$} & \multicolumn{2}{|l|}{$\begin{array}{l}\text { Lack of communication } \\
\text { of practical results }\end{array}$} & 10 & Practical results are not communicated and/or published. \\
\hline & & \multicolumn{2}{|l|}{$\begin{array}{l}\text { Lack of communication } \\
\text { of practical needs }\end{array}$} & 6 & $\begin{array}{l}\text { Decision-makers do not communicate their needs or do not ask scientists } \\
\text { for help. }\end{array}$ \\
\hline & \multirow{7}{*}{$\begin{array}{l}\text { General } \\
\text { problems }\end{array}$} & \multicolumn{2}{|l|}{ Cultural difficulties } & 43 & $\begin{array}{l}\text { Behaviors, negative attitudes or misguided perceptions towards each other } \\
\text { and differences between science and practice in terms of language, values } \\
\text { and working routines hinder the unidirectional flow of scientific } \\
\text { knowledge. }\end{array}$ \\
\hline & & \multirow{3}{*}{$\begin{array}{l}\text { Difficulties associated } \\
\text { with the } \\
\text { organizational context }\end{array}$} & Evaluation systems & 38 & $\begin{array}{l}\text { Evaluation and reward systems of scientists or decision-makers do not } \\
\text { consider acting in linking science and practice as an integral part of } \\
\text { professional activities. }\end{array}$ \\
\hline & & & Formal education & 18 & $\begin{array}{l}\text { Formal education does not prepare professionals to take part in the } \\
\text { activities involved in linking science and practice. }\end{array}$ \\
\hline & & & Resources & 22 & $\begin{array}{l}\text { Resources are lacking or funding schemes are incompatible with } \\
\text { involvement of scientists and decision-makers in linking science and } \\
\text { practice. }\end{array}$ \\
\hline & & \multirow{2}{*}{$\begin{array}{l}\text { Difficulties associated } \\
\text { with models of science } \\
\text { and of science- } \\
\text { practice linkages }\end{array}$} & Post-normal science & 2 & $\begin{array}{l}\text { A model assuming all forms of knowledge are equally valid devalues the } \\
\text { use of scientific knowledge and scientists' opinions in practice. }\end{array}$ \\
\hline & & & Neutral science & 6 & $\begin{array}{l}\text { A model of science assuming science must be neutral and objective, } \\
\text { without any influence of issues from outside academia, hinders the } \\
\text { linking of science and practice. }\end{array}$ \\
\hline & & $\begin{array}{l}\text { Complexity of } \\
\text { problems }\end{array}$ & & 12 & $\begin{array}{l}\text { Problems faced in practice are complex, involving diverse systems } \\
\text { interacting with each other and changing over time, hindering the linking } \\
\text { of science and practice. }\end{array}$ \\
\hline \multirow{2}{*}{$\begin{array}{l}\text { TWO } \\
\text { KNOWLEDGES }\end{array}$} & \multirow{2}{*}{$\begin{array}{l}\text { Problems in } \\
\text { interactions }\end{array}$} & \multicolumn{2}{|l|}{ Lack of interactions } & 19 & $\begin{array}{l}\text { Interactions, exchanges, partnerships, dialogues or collaborations between } \\
\text { science and practice are lacking. }\end{array}$ \\
\hline & & \multicolumn{2}{|l|}{$\begin{array}{l}\text { Epistemological } \\
\text { difficulties }\end{array}$} & 20 & $\begin{array}{l}\text { The nature of knowledge, the processes of generating knowledge deemed } \\
\text { valid or epistemological differences between science and practice hinder } \\
\text { interactions between them. }\end{array}$ \\
\hline
\end{tabular}




\begin{tabular}{|c|c|c|c|c|c|}
\hline \multicolumn{6}{|c|}{ Category } \\
\hline $\begin{array}{l}1^{\text {st }} \text { hierarchical } \\
\text { level }\end{array}$ & $\begin{array}{l}2^{\text {nd }} \text { hierarchical } \\
\text { level }\end{array}$ & $\begin{array}{c}3^{\text {rd }} \text { hierarchical } \\
\text { level }\end{array}$ & $\begin{array}{l}4^{\text {th }} \text { hierarchical } \\
\text { level }\end{array}$ & $\mathbf{N}$ & Brief explanation of each perceived cause \\
\hline & & Cultural difficulties & & 24 & $\begin{array}{l}\text { Behaviors, negative attitudes or misguided perceptions towards each other } \\
\text { and cultural differences between science and practice in terms of } \\
\text { language, values and working routines hinder interactions between them. }\end{array}$ \\
\hline & & \multirow{4}{*}{$\begin{array}{l}\text { Difficulties associated } \\
\text { with the } \\
\text { organizational context }\end{array}$} & Evaluation systems & 19 & $\begin{array}{l}\text { Evaluation and reward systems of scientists and decision-makers do not } \\
\text { consider interactions between science and practice as an integral part of } \\
\text { professional activities and do not value knowledge produced in these } \\
\text { interactions. }\end{array}$ \\
\hline & & & Formal education & 7 & $\begin{array}{l}\text { Formal education does not prepare scientists and decision-makers to act in } \\
\text { an integrated manner. }\end{array}$ \\
\hline & & & Resources & 6 & $\begin{array}{l}\text { Resources are lacking or funding schemes are incompatible with } \\
\text { supporting interactions between science and practice. }\end{array}$ \\
\hline & & & High turnover in practice & 2 & $\begin{array}{l}\text { Employment positions for decision-makers in organizations involved in } \\
\text { practice have high turnover, impeding fruitful interactions with the } \\
\text { scientific community. }\end{array}$ \\
\hline & & \multirow{3}{*}{$\begin{array}{l}\text { Difficulties associated } \\
\text { with models of science } \\
\text { and science-practice } \\
\text { linkages }\end{array}$} & Linear model & 15 & $\begin{array}{l}\text { A model assuming a unidirectional flow of knowledge from science to } \\
\text { practice hinders interactions between science and practice. }\end{array}$ \\
\hline & & & $\begin{array}{l}\text { Model emphasizing scientific } \\
\text { rigor/quality }\end{array}$ & 2 & $\begin{array}{l}\text { A model assuming the science-practice gap is due only to lack of scientific } \\
\text { rigor and the solution to environmental problems lies on a science of } \\
\text { better quality hinders interactions between science and practice. }\end{array}$ \\
\hline & & & $\begin{array}{l}\text { Model emphasizing objective } \\
\text { and impartial knowledge }\end{array}$ & 8 & $\begin{array}{l}\text { A model that values only explicit, objective and impartial (i.e., value-free) } \\
\text { knowledge and disregards other knowledge types hinders interactions } \\
\text { between science and practice. }\end{array}$ \\
\hline ONE ACTOR & & & & 5 & $\begin{array}{l}\text { Scientists themselves do not perform practical activities or face difficulties } \\
\text { in performing them. }\end{array}$ \\
\hline
\end{tabular}


The reliability coefficient was greater than 0.67 at the first three higher hierarchical levels of the framework for both set of sentences (Appendix S5), assuring adequate reliability in terms of repeatability of the categorization procedure (Krippendorff, 2004). Although coefficients were moderately lower for the fourth hierarchical level, observed agreement was still closer to perfect agreement than to agreement expected by chance (>0.50; Appendix S5). Hence, within this lower hierarchical level, we based our interpretations on which perceived causes of the science-practice gap predominated in the ecological and conservation literature only on expressive differences between categories of perceived causes (i.e., those differences probably sustained irrespective of the identity of the person categorizing the sentences).

\section{Article coding}

We recorded whether each of the 122 articles included or not sentences allocated in each category of the conceptual framework (Appendix S3). To analyze the predominance of the categories of perceived causes over time and across journals with distinct research traditions, both the publication year and the scientific journal where each article was published were recorded.

\section{RESULTS}

\section{Conceptual framework}

We identified 48 lower-level categories of perceived causes of the sciencepractice gap arranged into four hierarchical levels, representing different processes linking science and practice that are considered flawed, inefficient or not occurring (Table 1, Appendix S6). The first hierarchical level divides the causes into three major categories, representing markedly different perspectives of ecologists and conservation scientists regarding which knowledge or actors are important in linking science and practice (Fig. 2). Thus, for each perspective, the processes linking science and practice are different, constituting the second hierarchical level of the framework (Fig. 2). 


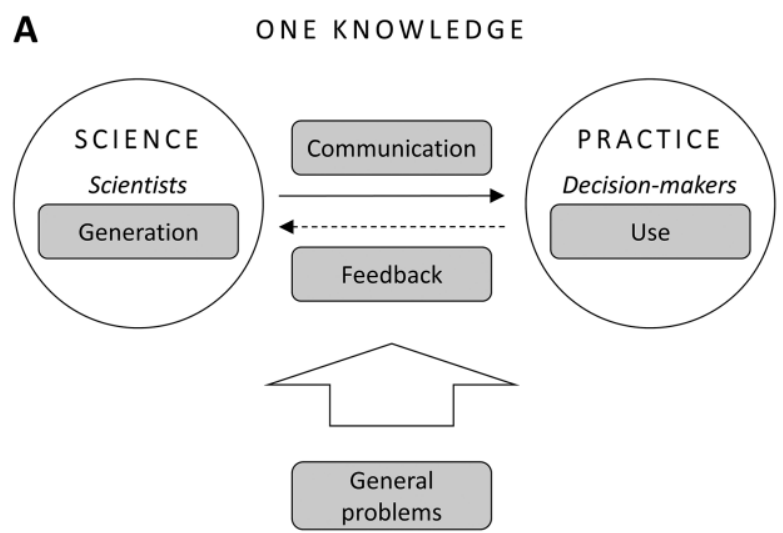

B TWO KNOWLEDGES
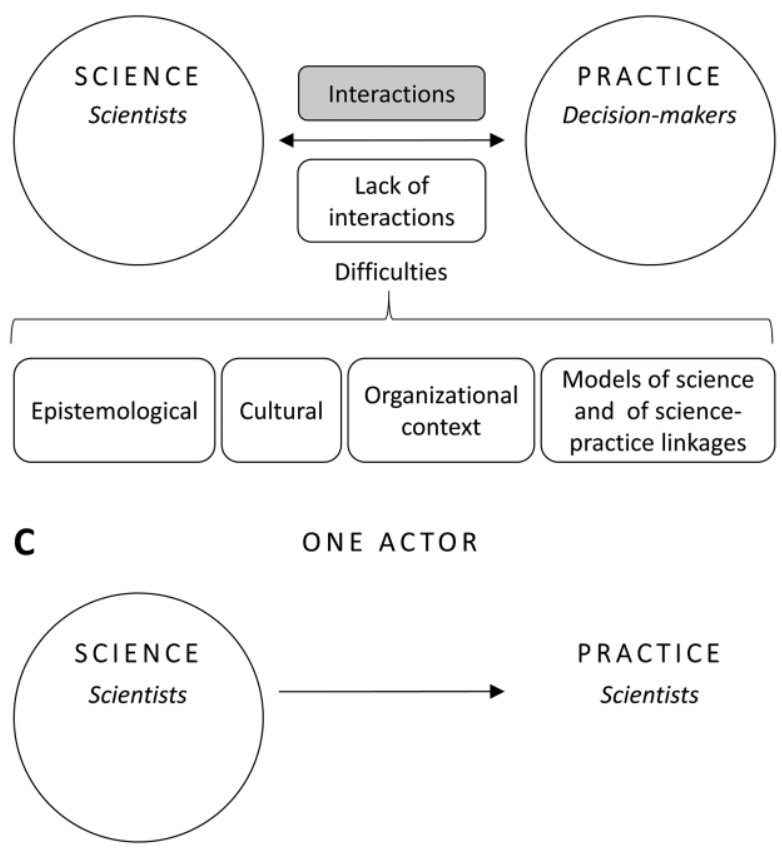

Figure 2. Schematic representation of the three perspectives regarding which knowledge or actor is considered important in linking science and practice in Ecology and Conservation. Text in italic represents recognized actors within each perspective, gray boxes represent the processes that are considered flawed (i.e., second hierarchical-level categories of perceived causes), and white boxes represent the third hierarchical level of perceived causes. (A) The perspective "One knowledge" assumes only scientific knowledge is important to support decision-making, therefore establishing a unidirectional flow of knowledge from science to practice (one-way continuous arrow), with possible feedback of practical needs (one-way dashed arrow). (B) The perspective "Two knowledges" assumes both science and practice should contribute with knowledge to support practice, therefore establishing a collaborative process of knowledge integration via interactions between scientists and decision-makers (twoway continuous arrow). (C) The perspective "One actor" assumes only scientists are important actors and should act in doing conservation, besides producing scientific knowledge. 
The first major category ("One knowledge") represents a perspective in which both scientists and decision-makers are recognized as actors, but only scientific knowledge is considered important to support decision-making, therefore establishing a unidirectional flow of knowledge from science to practice (Fig. 2A). In this case, the linkage between science and practice is often described with terms such as "adoption", "transmitting", "transferring", and "translating", implying a view of scientific knowledge being produced in science and assimilated into practice:

We [scientists] must recognize our role in translating science into management and policy. We have been successful at times with this translation, especially when research has been motivated by a specific management question, but in general our record in this regard is poor. [...] we can do far more to transfer scientific understanding to practice.

(Hall \& Fleishman, 2010, p. 121)

In contrast, the perspective of the second major category ("Two knowledges") assumes both science and practice should contribute with knowledge to support decision-making, therefore establishing a collaborative process of knowledge production and integration via interactions between scientists and decision-makers (Fig. 2B). In this case, common terms are "exchanges", "partnerships", "dialogues", "collaborations", "learning", “integration" and "co-production", suggesting interactions between scientists and decision-makers are understood as a process with intellectual contribution of both parties rather than a process facilitating scientific knowledge transfer:

... the lack of interaction between scientists and practitioners poses further challenges to produce socially robust knowledge and solve sustainability problems [...] Attempts to link scientists and practitioners in sustainability science aim to strengthen the exchange and integration of different disciplinary and non-academic knowledge, enabling mutual learning between scientists and practitioners...

(Brandt et al., 2013, pp. 1-2)

Lastly, the third major category (“One actor") is associated with a perspective on the science-practice linkage that disregards decision-makers, assuming only scientists are important actors and should act in "doing" conservation or "putting results into practice", besides producing scientific knowledge (Fig. 2C): 
Researchers dealing with conservation subjects usually do not put the results of their work into practice, even when the primary purpose of their research is the preservation of biodiversity.

(Gallo et al., 2009, p. 895)

However, this third major category was rare, being present in only five articles, and, therefore, was not divided into further categories.

\section{“One knowledge” perspective}

The important processes linking science and practice from the perspective "One knowledge" - which considers only scientific knowledge is important to support decision-making - are the generation, communication and use of scientific knowledge, as well as the feedback from practice to science regarding research needs and practical results (Fig. 2A). Thus, within this perspective, the second-level categories of causes of the science-practice gap are associated with problems deemed to affect one or all of these processes (Figs. 2A and 3A).

The category "Problems in knowledge generation" is further divided into three third-level categories associated with (1) the research process, (2) the characteristics of the produced knowledge, and (3) knowledge gaps (Fig. 3A). In the first case, the perceived causes of the gap lie on flaws, errors or inefficiencies in scientific research. For example, some authors argue a fragmentation of research efforts (Githiru et al., 2011) or a reductionist approach in scientific research (Cabin, 2007) renders research incompatible with the generation of useful knowledge for practice. In the second case, causes are related to characteristics of scientific research products (either scientific knowledge or proposed practical recommendations derived from it) that are perceived to render them irrelevant to practice, such as the difficulty of using scientific knowledge that is abstract (Sunderland et al., 2009) or uncertain (Bradshaw \& Borchers, 2000). Finally, in the third case, perceived causes refer to a lack of knowledge or recommendations regarding relevant questions to practice. 
A

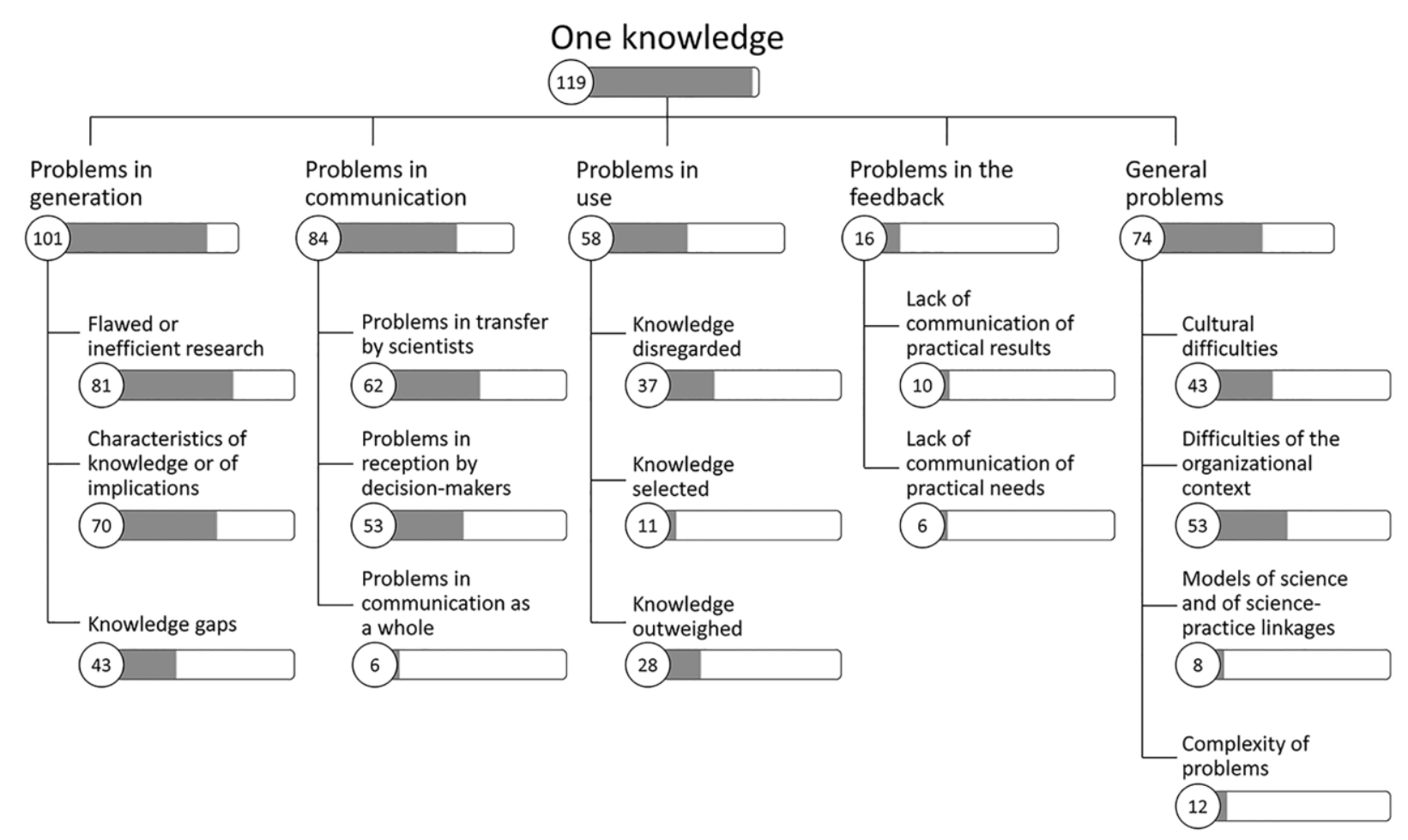

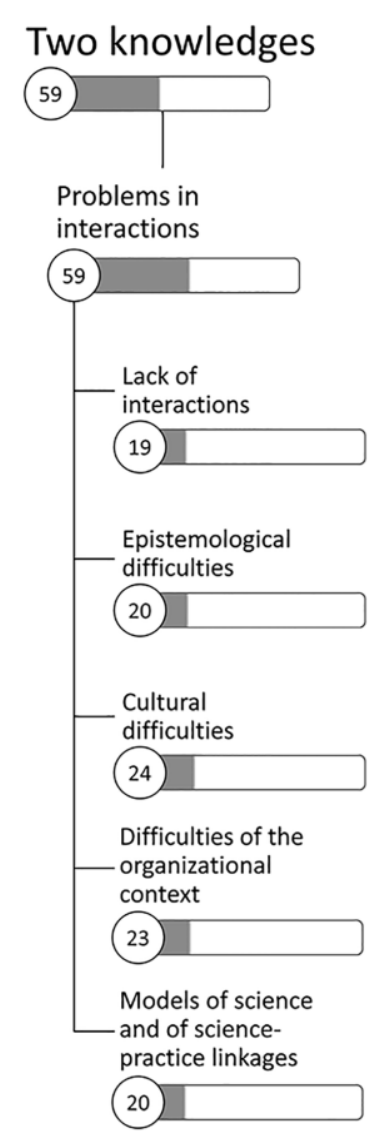

Figure 3. Hierarchical organization of the second- and third-level categories of perceived causes of the science-practice gap in Ecology and Conservation within the perspectives "One knowledge" (A) and "Two knowledges" (B), showing the number (inside circles) and the proportion (bars) of articles (N=122) that contained sentences allocated to each category. 
The category "Problems in knowledge communication" is also divided into three third-level categories (Fig. 3A). The first refers to the perception of flaws, errors or inefficiencies in communication processes for which scientists are deemed responsible; that is, scientists either do not make scientific knowledge available for decision-makers (e.g., only publishing in scientific journals read by their own peers; Dramstad \& Fjellstad, 2012) or translate available knowledge in formats, language or tools that are inadequate for decision-makers (e.g., Finch \& Patton-Mallory, 1993). The second one refers to perceived problems in the reception of knowledge by decision-makers: they either do not access scientific literature, for example, because of lack of time in daily activities (e.g., Shaw, Wilson \& Richardson 2010), or have trouble understanding scientific knowledge (e.g., Bradshaw \& Borchers, 2000). The third one refers to problems perceived to affect the communication process as a whole, such as the high costs in terms of resources and time involved in communicating scientific knowledge to practice (Seavy \& Howell, 2010).

The category "Problems in knowledge use" also included three third-level categories (Fig. 3A). The first implies the idea scientific knowledge is disregarded in practice, either because decision-makers reject it, for example, when new scientific ideas contradict personal beliefs (McCleery, Lopez \& Silvy, 2007), or is not used because of the structure of organizations involved in practice (e.g., Murphy \& Kaeding, 1998). The second and third categories refer to the perception of scientific knowledge being (1) partially selected to support decision-makers' interests (e.g., Peuhkuri, 2002), or (2) outweighed by other factors (e.g., by political interests; Barbour et al., 2008).

Although the "One knowledge" perspective assumes a unidirectional flow of knowledge from science to practice, some articles also indicated perceived problems in the feedback from practice to science ("Problems in the feedback from practice", Fig. 3A). In this category, causes were related to a perceived lack of communication either (1) of practical results or (2) of research needs back to scientists. For example, Finch \& Patton-Mallory (1993) argue land managers have not always done a good job explaining their needs or soliciting research help.

Finally, some articles reported causes perceived to affect more than one process linking science and practice, hindering as a whole the flow of knowledge originating in scientific research (Fig. 2A). We grouped those perceived causes into the category "General problems", divided into four third-level categories (Fig. 3A). The first one 
refers to cultural aspects (i.e., values, expectations, perceptions, attitudes, and/or behaviors) of scientists and/or decision-makers deemed to hinder the knowledge flow from science to practice, e.g., misguided perceptions and criticisms from one side towards the other preventing an effective conversion of scientific findings into management actions (e.g., Cabin, 2007). The second category includes aspects of the organizational context, associated with the perception that either (1) professional evaluation systems do not reward scientists for engaging in processes related to the flow of scientific knowledge to practice; (2) formal education does not train professionals to engage in these processes; or (3) resources are lacking to support such activities. Bainbridge (2014), for example, criticizes formal scientific education for not exposing students to the functioning and methods of policy-making. The third and fourth categories are related to current predominant models governing scientific production and science-practice linkages and to the complexity of problems faced by decision-makers (Fig. 3A), which were also perceived to affect all the processes of knowledge generation, communication and use as well as feedback.

\section{"Two knowledges" perspective}

Within the perspective "Two knowledges", which assumes both science and practice should contribute with knowledge to support decision-making, we identified only one important process deemed to link science and practice: knowledge integration via interactions between scientists and decision-makers (Fig. 2B). Thus, this perspective includes a single second-level category "Problems in interactions" (Fig. 3B).

The category "Problems in interactions" is in turn subdivided into five third-level categories of perceived causes (Fig. 3B): one related to lack of interactions between science and practice, without delving into the underlying reasons, and four categories dealing with different factors perceived to hinder or prevent interactions. The first category of factors perceived to hinder interactions - "Epistemological difficulties" encompasses differences between science and practice regarding either the nature of knowledge or which knowledge generation processes are deemed valid. For example, Hulme (2014) stresses that while science seeks generalizations, practical knowledge is context-dependent and variable across decision-makers, complicating knowledge integration. The other categories of factors deemed to hinder interactions are related to 
perceived difficulties associated with cultural aspects, the organizational context, and predominant models of science and science-practice linkages (Fig. 3B). The category "Difficulties associated with the organizational context" is further subdivided into (1) professional evaluation systems, (2) formal education, (3) lack of resources, and (4) high turnover of decision-makers' employment positions. For example, in the latter category, Shackleton et al. (2009) perceived the constant change of people involved in practice as a major difficulty in developing social learning partnerships. Lastly, the category "Difficulties associated with models of science and science-practice linkages" is subdivided into three different models perceived to hinder interactions between science and practice (e.g., the linear model of knowledge dissemination from scientists to decision-makers focusing on knowledge transfer and translation; Shackleton et al., 2009).

Many perceived causes within "Problems in interactions" (Fig. 3B) are similar to those perceived to affect as a whole the unidirectional flow of knowledge from science to practice in the "General problems" category, within the "One knowledge" perspective (Fig. 3A). However, perceived causes within "Problems in interactions" are deemed to hinder knowledge integration between scientists and practitioners, while causes within "General problems" are perceived to impair the linear flow of knowledge from science to practice.

\section{Predominance of perceived causes of the science-practice gap in the literature, over the years and across journals}

From the 122 reviewed articles, 92 were published in the last decade. In fact, the proportion of articles mentioning causes of the science-practice gap in Ecology and Conservation increased over the years, particularly since 2007 (Fig. 4A).

Half of the reviewed articles included causes of the science-practice gap from just one major perspective (mainly "One knowledge"), while the other half included causes from two or all three major perspectives, mainly "One knowledge" and "Two knowledges" (Fig. 4A). The "One knowledge" perspective - which considers only scientific knowledge is important to support decision-making - was the most common perspective overall (Fig. 4A), with only three articles not including perceived causes of the science-practice gap from this perspective (Fig. 4A). The "Two knowledges" perspective - i.e., assuming both science and practice should contribute with 
knowledge to support decision-making - was the second most common, while the "One actor" perspective - which assumes only scientists are important actors - was the least common (Fig. 4A). The proportion of articles associated with the perspectives "One knowledge" and "Two knowledges" did not change substantially over the years, while the few articles including perceived causes from the "One actor" perspective were published more recently, between 2008 and 2011 (Fig. 4A).

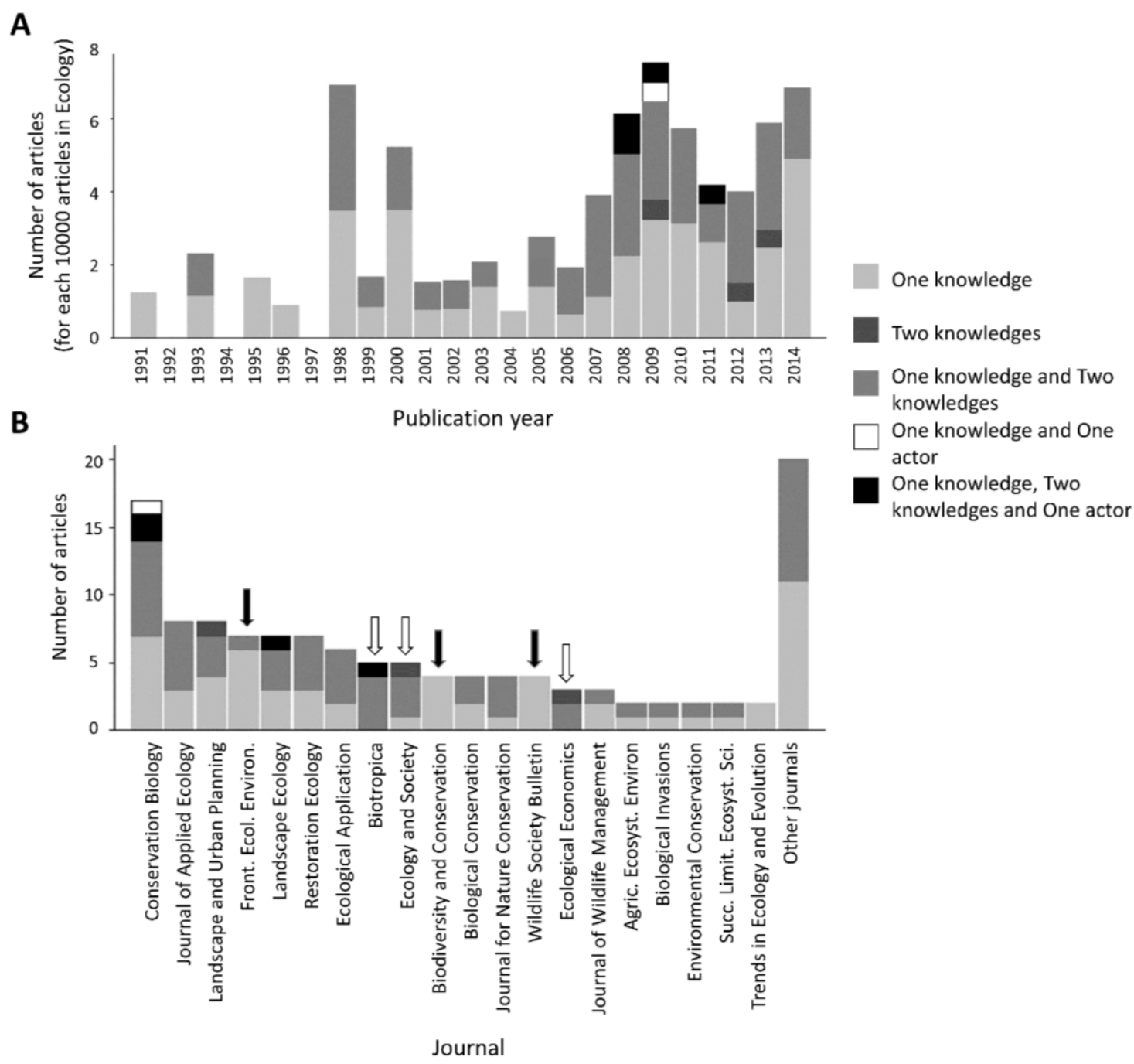

Figure 4. Distribution of reviewed articles associated with each major category of perceived causes of the science-practice gap in Ecology and Conservation over the years (A) and across scientific journals (B). In A, bars represent the number of reviewed articles divided by the total number of articles indexed in the categories "Ecology" and "Biodiversity Conservation" in the "Web of Science Core Collection" for each publication year. In B, black arrows point to journals dominated by articles associated only with the major category "One knowledge" and open arrows, to journals dominated by articles associated also with the major category "Two knowledges". Front. Ecol. Environ. = Frontiers in Ecology and the Environment; Agric. Ecosyst. Environ. = Agriculture Ecosystems \& Environment; Succ. Limit. Ecosyst. Sci. = Successes, Limitations, and Frontiers in Ecosystem Science. 
The reviewed articles were published mostly in "Conservation Biology", followed by "Journal of Applied Ecology" and "Landscape and Urban Planning" (Fig. 4B). The proportion of reviewed articles associated with each perspective was similar across most scientific journals (Fig. 4B). However, articles published in "Frontiers in Ecology and the Environment", "Biodiversity and Conservation" and "Wildlife Society Bulletin" were predominantly associated only with the perspective "One knowledge", while most articles published in "Biotropica", "Ecology and Society" and "Ecological Economics" also included perceived causes from the perspective "Two knowledges" (Fig. 4B).

Considering the "One knowledge" perspective, causes referring to "Problems in knowledge generation" were present in approximately $80 \%$ of the articles, being the most common in the second hierarchical level, followed closely by "Problems in knowledge communication" and "General problems" (Fig. 3A). Within the category "Problems in knowledge generation", causes related to research process or characteristics of knowledge were the most frequent (Fig. 3A). Within the category "Problems in knowledge communication", the number of articles citing causes in knowledge transfer was slightly greater than in knowledge reception (Fig. 3A). The inadequate translation of scientific knowledge by scientists (within knowledge transfer) was the most cited lower-level category of the entire framework, being mentioned by $40 \%$ of reviewed articles (Table 1). Within "Problems in knowledge use", knowledge being disregarded in practice appeared more frequently in the literature than knowledge being selected by decision-makers to fit their own interests or being outweighed by other factors (Fig. 3A). Finally, within the category "General problems", the most common perceived causes were those related to cultural aspects or difficulties associated with the organizational context (Fig. 3A), the latter reflecting the high proportion of articles mentioning that professional evaluation systems hinder the flow of knowledge from science to practice (Table 1).

Regarding the "Two knowledges" perspective, all categories of perceived causes related to "Problems in the interactions" were equally frequent in the literature, being found in approximately one fifth of the articles (Fig. 3B). Most articles mentioning causes in the categories "Difficulties associated with the organizational context" and "Difficulties associated with models of science and science-practice linkages" refer to 
problems perceived to be associated with professional evaluation systems and a linear model of knowledge transfer from science to practice, respectively (Table 1).

When divided by publication year, the proportion of reviewed articles including causes from second- and third-level categories did not change substantially over time (Appendix S7). Fourth-level categories presented too few articles to allow division by publication year. All trends described in this section remain similar considering only the articles expressing exclusively the authors' ideas, i.e., after excluding the 21 articles that empirically investigated the opinions of scientists or decision-makers (Appendix S8).

\section{DISCUSSION}

We reviewed the scientific literature in Ecology and Conservation and, by using an inductive text analysis approach, organized the perceived causes of the sciencepractice gap into a process-based conceptual framework. We identified three perspectives of ecologists and conservation scientists on the important processes linking science and practice, coexisting in the literature frequently within the same articles and journals. In the next sections, we first discuss the most predominant causes of the science-practice gap perceived by ecologists and conservation scientists, and then contextualize the identified perspectives in terms of predominance over time and across journals with distinct research traditions. Next, we consider insights from scientific disciplines studying the role of science in decision-making and its relation to society to highlight the strengths and limitations of ecologists and conservation scientists' perspectives on the science-practice gap. Lastly, we describe the implications for fostering productive linkages between science and practice in Ecology and Conservation and close with our main conclusions.

\section{The perceived causes of the science-practice gap in Ecology and Conservation}

Within the perspective "One knowledge", the great majority of articles mentioned "Problems in knowledge generation", suggesting the generation of scientific knowledge is a widely-acknowledged problem causing the science-practice gap among ecologists and conservation scientists. The idea that current scientific processes may be inadequate to help face societal challenges is also present in the critique of the implicit social contract of science (i.e., science supplies knowledge to society in 
exchange of support through taxes and liberty to self-regulate; NASEM, 2015). According to Lubchenco (1998), such contract is no longer sufficient to confront the pressing environmental challenges, and a new contract is needed in which science is directed to the most pressing problems. However, this is definitely a controversial view, considering science searching for explanations that provide intellectual satisfaction (Braithwaite, 1955) is also important both for understanding the systems we may wish to conserve (Dayton, 2003) and for general advances in technology (Oates, 2013). Hence, a focus on diverse ways of conducting science may be more adequate and useful.

Within the category "Problems in knowledge generation", causes related both to scientific research and to characteristics of scientific knowledge were often mentioned. This makes sense given the fragmentation of research efforts and inadequate research questions and scales (the most cited causes related to the research process) were perceived to render scientific knowledge irrelevant (the most cited cause related to characteristics of knowledge). The prevalence of these causes in the literature points to a general perception that conducting more relevant research is the main step towards bridging the science-practice gap, a perception also common within the medical field (Cairney, 2016). Indeed, several articles in Ecology and Conservation discuss what renders scientific knowledge relevant to practice (e.g., Cash et al., 2003; Cook et al., 2013). This also suggests ecologists and conservation scientists may place great importance in transforming institutional and organizational arrangements of science to allow generation of knowledge that is relevant to practice.

Besides being irrelevant to practice, characteristics inherent to scientific knowledge, such as uncertainty and controversy, were also frequently cited as causes of the science-practice gap. For example, the uncertainty associated with scientific knowledge is perceived as hindering its acceptance and use in practice, because most decision-makers seek for certainty (Bainbridge, 2014) and/or are not used to probabilistic modes of discourse (Bradshaw \& Borchers, 2000). However, any knowledge about the empirical world is inherently uncertain and conjectural, and even the most consensual topics are surrounded by irreducible uncertainty (Dovers, Norton \& Handmer, 1996; Bradshaw \& Borchers, 2000). In Ecology and Conservation, uncertainty may be an even more pressing problem for applying scientific knowledge than in other disciplines, partially because they are relatively young sciences and there 
is still much to understand, but also because of the inherent complexity of ecological and socio-ecological systems (Dovers et al., 1996; Polasky et al., 2011). Although uncertainty can be reduced over time, it is not a problem in itself, but an inherent characteristic of scientific knowledge, which may be miscomprehended (Bradshaw \& Borchers, 2000), potentially leading to rejection of ecological knowledge among decision-makers (van Latesteijn, 1998), and to ambiguity and complication in public debate when science is brought to assist decision-making (Sarewitz, 2004; Cairney, 2016).

The ecological and conservation literature also encompassed perceived causes of the science-practice gap related to another intrinsic characteristic of scientific knowledge, namely its abstract nature. This is surprising as it suggests a misconception from scientists themselves about science and its potential for solving problems. Being abstract means scientific knowledge aims at generalizations, building general propositions applicable to different situations and contexts (Tress et al., 2005). Precisely because it is general, scientific knowledge has explanatory and predictive power. Nonetheless, knowledge generalizability can be limited in some instances, which has also been perceived as hampering productive science-practice linkages ("Limited generalizability", Table 1). Ecological generalizations, in contrast to generalizations in other disciplines, have a more restricted application domain (Weber, 1999; El-Hani, 2006), and some have proposed developing solutions to specific problems may often require that new local, context-specific knowledge - and therefore not applicable elsewhere - is produced (Tress et al., 2005). However, generalized ecological knowledge (i.e., ecological theories and models), by identifying key processes or mechanisms, can help recognizing which specific information is needed in particular situations or contexts.

Although problems in knowledge generation were more salient, an inadequate translation, included in the category "Problems in knowledge communication", was the most cited lower-level category of the entire framework. Indeed, translation difficulties are perceived to result from failures in several other processes, such as formal education, as well as from characteristics of scientific knowledge, such as uncertainty. Formal scientific education does not usually focus on the processes and methods used in decision-making or on human interaction skills (Cannon, Dietz \& Dietz, 1996; Jacobson \& Duff, 1998; Baxter et al., 1999), possibly leading to lack of competence on 
how to present scientific knowledge for audiences outside academia, or how to frame scientific knowledge into relevant and meaningful practical recommendations. In addition, scientific uncertainty was perceived as increasing the challenge of translating science in a meaningful way to decision-makers (Dovers et al., 1996; Bradshaw \& Borchers, 2000). However, as Bainbridge (2014) suggests, although most authors place an onus on scientists for improving communication, decision-makers' responsibility to understand and engage with science should not be overlooked.

In the category "Problems in knowledge use", the most commonly cited cause was a disregard for scientific knowledge in practice. This was perceived to be a result of either an organizational impediment, such as a lack of operational capacity to implement science-based recommendations (Young \& Van Aarde, 2011) or of science rejection by decision-makers. Rejection, in turn, was perceived to be associated with, among other factors, the lack of trust in knowledge sources (Lauber et al., 2011), resistance to change managing paradigms (McCleery et al., 2007) or unjustified expectations towards scientific knowledge, e.g., certainty (Bradshaw \& Borchers, 2000). Irrespective of the reason, this cause prevalence in the literature suggests a widespread perception among scientists that ecological and conservation science is rarely used and is rejected by practitioners in decision-making.

Although less frequent than problems in knowledge generation and communication, causes associated with "General problems" within the perspective "One knowledge", which were perceived as overall hindering the knowledge flow from science to practice, were commonly mentioned. Many of these causes were similar to those perceived as hindering knowledge integration and interactions between scientists and decision-makers within the perspective "Two knowledges". Within both perspectives, problems related to professional evaluation systems were the most commonly cited within the category "Difficulties associated with the organizational context". This indicates such systems are perceived as a hurdle to a broad range of processes expected to link science and practice, for example, because the focus on the quantity of high impact publications discourages scientists to dedicate time to knowledge communication or integration (Shanley \& López, 2009; Born, Boreux \& Lawes, 2009; Sunderland et al., 2009; Whitmer et al., 2010). Similarly, cultural aspects of scientists and decision-makers arising from different values, attitudes and languages (e.g., Cabin, 2007), or ingrained misconceptions and negative attitudes towards one 
another (e.g., Roux et al., 2006), are also commonly perceived as hampering both the flow of knowledge from science to practice and the integration of scientific and practical knowledge.

Within the perspective "Two knowledges", the categories "Epistemological difficulties" and "Difficulties associated with models of science and science-practice linkages" (especially a linear model of knowledge transfer) were as common as the cultural and organizational aspects mentioned above. Epistemological difficulties such as different conceptions of scientists and decision-makers on the nature of knowledge and how it should be produced - have already been reported as significant challenges hindering integration of different knowledge sources, given that different conceptions prevent consensus on how to integrate knowledge or which integration outputs are valuable (Raymond et al., 2010). In fact, the hindrance to integrative processes between scientists and decision-makers perceived to be caused by the linear model can be explained by such epistemological challenges, as this model places greater importance on scientific knowledge, simultaneously devaluing other knowledge types, such as context-situated practical knowledge.

Apparently, scientists in distinct fields perceive similar causes affecting the science-practice gap. This is the case of cultural difficulties and professional evaluation systems, also perceived as a hindrance to linking science and practice in Education (Anderson, 2007; Broekkamp \& Hout-Wolters, 2007), Nursing (Closs \& Cheater, 1994), and Medicine (Waddell, 2002; Nutley, Walter, \& Davies, 2007). However, certain aspects of scientific knowledge generation, such as research being conducted at inadequate scales (i.e., either temporal or spatial scales different from those relevant to decision-makers) and research being limited because of scale, time and funding issues, seem to be perceived as a cause of the science-practice gap only in Ecology and Conservation. Comparing the conservation and medical fields, Walsh (2015) identified several perceived barriers specific to conservation, including the problem of research scale. Indeed, relevant temporal and spatial scales in Ecology and Conservation are more varied than in other disciplines, ranging from genes to ecosystems (Pullin \& Knight, 2005). Research funding and larger samples are also harder to obtain in Ecology and Conservation (e.g., when compared to medicine; Fazey et al., 2004). Despite differences in perceived causes, our conceptual framework suggests the science-practice gap in Ecology and Conservation is perceived to be as complex and 
multifaceted as within other scientific disciplines (Broekkamp \& Hout-Wolters, 2007; Nutley et al., 2007).

The variety of perceived causes of the science-practice gap in Ecology and Conservation requires three distinct, general types of solutions (Fig. 5). First, several perceived causes require solutions directly eliminating the causal factor (Fig. 5A). For example, inadequate research questions were often perceived as a causal factor. To eliminate this factor and change research agendas, lists of priority topics have been developed by consulting scientists and practitioners (e.g., Sutherland et al., 2009; Jones et al., 2015). Second, some perceived causes are related to factors that cannot be eliminated or changed, such as those regarding intrinsic characteristics of ecological knowledge (e.g., uncertainty). Here, solutions require the recognition of, and then ways to deal with, the problem or factor (Fig. 5B), such as assisting decision-makers to tackle uncertainty via adaptive management or scenario planning (Dovers et al., 1996; Polasky et al., 2011). Finally, some perceived causes cannot be tackled by either eliminating or dealing with the causal factor, given they are mostly based on misconceptions (Fig. 5C). For example, the perceived cause of scientific knowledge being abstract is either a misconception about the potential of generalized knowledge to guide action or an incorrect use of concepts such as "abstract" or "conceptual”. Either way, a more adequate solution would be to foment discussions on the nature of knowledge, including historical, philosophical and sociological approaches to science.

\section{The perspectives of ecologists and conservation scientists on the science-practice gap}

By classifying the perceived causes of the science-practice gap in Ecology and Conservation into a process-based framework, we identified three distinct perspectives or ways to understand the interface. The perspective "One knowledge" assumes only scientific knowledge should support practice, establishing a unidirectional flow of knowledge from science to practice, while the perspective "Two knowledges" assumes both scientists and decision-makers should collaboratively support practice. The perspective "One actor" in turn disregard decision-makers by assuming scientists should put their results into practice. Although this is, to our knowledge, the first formal review on the science-practice gap in Ecology and Conservation, the few studies exploring conceptualizations of the interface in this field mention perspectives alike the 
ones we identified. For example, Roux et al. (2006) portray ongoing initiatives to link science and practice in sustainable ecosystem management as adhering to a model of unidirectional knowledge transfer and argue instead for bidirectional knowledge sharing processes. Likewise, among the framings of interactions between science and environmental or conservation policy presented by Pregernig (2014), several focus mainly on scientific knowledge, while only one recognizes a plurality of knowledge systems.

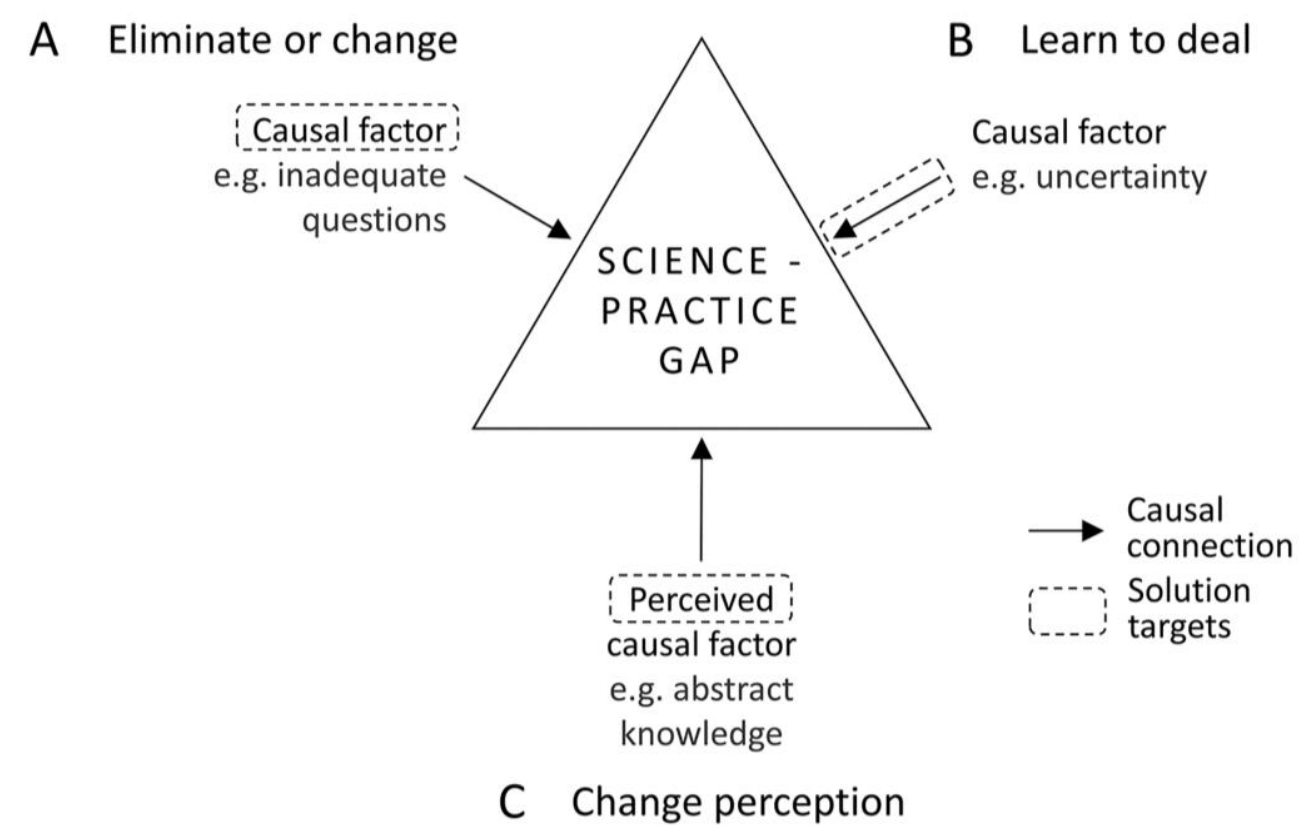

Figure 5. Distinct types of solutions to the perceived causes of the science-practice gap in Ecology and Conservation. (A) Solutions that aim at eliminating or changing the causal factor. (B) Solutions that aim at recognizing and dealing with problems (causal factors) that cannot be eliminated. (C) Solutions that aim at changing the perception of causal factors that are based on misconceptions about the potential of science for supporting practice. 
In fact, the two main perspectives on the science-practice gap we identified also parallel those recognized among scientists from other disciplines, such as Medicine and Education. In these disciplines, earlier ideas of research utilization in practice suggested a linear transfer of information (Huberman, 1994; Nutley et al., 2007), equivalent to our major category "One knowledge". However, recently, the linear view has been replaced by integrative conceptions highlighting dialogue and knowledge integration between researchers and practitioners (Waddell, 2002; Nutley et al., 2007; Vanderlinde \& van Braak, 2010), similarly to our major category "Two knowledges". Despite this historical tendency in other disciplines, the proportion of articles associated with our two major categories did not substantially change over time and there was a clear prevalence of the "One knowledge" perspective. Our findings thus suggest the debate on the science-practice gap in Ecology and Conservation may lag behind discussions in other disciplines, being still dominated by a perspective assuming a linear flow of knowledge from science to practice and a primacy of scientific knowledge.

The prevalence of the linear view of knowledge transfer may be associated with the leverage or prestige of the evidence-based approach in Ecology and Conservation (Toomey et al., 2016). This approach, transposed from Medicine to Conservation, focuses on methods that systematically collate and synthesize scientific evidence to enhance the flow of knowledge from science to practice (Pullin \& Knight, 2001; Fazey et al., 2004; Sutherland \& Pullin, 2004; Dicks, Walsh, \& Sutherland, 2014). More than ten years after its proposal (Pullin \& Knight, 2003; Sutherland \& Pullin, 2004), the evidence-based approach has become widely established, resulting in journals (e.g., Conservation Evidence), online databases (e.g., www.conservationevidence.com, www.environmentalevidence.org), and international collaborations (e.g., Collaboration for Environmental Evidence), and has been found to effectively facilitate the use of science in practice (Walsh, Dicks \& Sutherland, 2015). However, although the evidence-based approach acknowledges the need to integrate scientific and nonscientific knowledge in decision-making (Fazey et al., 2004; Haddaway \& Pullin, 2013; Walsh, 2015), there has been a focus on the systematic collation of scientific evidence and less so on the integration of different knowledge sources (Adams \& Sandbrook, 2013; Walsh, 2015). This dominance may have precluded advances towards perspectives emphasizing interactions between scientists and decision-makers and the use of local and practitioners' knowledge to deal with environmental problems. 
In contrast to the evidence-based approach originating in Medicine, integrative approaches for linking science and practice are more common in Education (e.g., McIntyre, 2005; El-Hani \& Greca, 2013). These initiatives are inspired by contributions emphasizing learning and knowledge production as an integral part of social practice, such as social learning theories (e.g., Lave \& Wenger, 1991) and communities of practice (Wenger, 1998, 2011). In Ecology and Conservation, some similar successful experiences have been reported, such as those integrating scientific knowledge with decision-makers' strategic knowledge (sensu Hulme, 2014) about what is legislatively, politically and administratively feasible (Pardini et al., 2013; Rigueira et al., 2013), or initiatives also incorporating local resource users and their (traditional) knowledge (Knight \& Cowling, 2006; Shackleton et al., 2009). Hence, although the medical field has provided many important lessons for linking science and practice in Ecology and Conservation, as attested by the success of evidence-based approaches, avoiding dominance in the debate regarding the science-practice gap will require inspiration is also sought in other disciplines such as Education.

Despite the unchanged predominance of the "One knowledge" perspective over time, the distribution of perspectives on the science-practice gap across ecological and conservation journals was not homogeneous. Even though the proportion of articles associated with each perspective was similar across most journals, some are dominated by articles mentioning causes of the gap related only to the linear perspective "One knowledge", while in others most articles include also the "Two knowledges" perspective. The former are associated with conservation and wildlife management traditions, such as "Biodiversity and Conservation" and "Wildlife Society Bulletin", whereas the latter are mostly linked to traditions such as sustainability science and socio-ecological resilience, e.g., "Ecology and Society" and "Ecological Economics". The focus on interaction and knowledge integration between scientists and decisionmakers, besides being less frequent, may thus have also been primarily restricted to research traditions historically isolated from mainstream conservation biology (Curtin \& Parker, 2014). Together with the overall dominance of the "One knowledge" perspective over time, this reinforces the idea of a debate dominated by a single linear view of knowledge transference from science to practice, which may prevent the incorporation of diverse perspectives when planning solutions for improving the use of science in decision-making (Carpenter et al., 2009). 


\section{Putting into context the perspectives of ecologists and conservation scientists on}

the science-practice gap

As understanding the process of decision-making can bring a broader perception of the role of science (Oliver, Lorenc \& Innvaer, 2014), the debate on the sciencepractice gap in Ecology and Conservation can be enlightened by considering the input of disciplines such as STS studies and Political Science. While these disciplines focus mainly on decision-making processes (Cairney, 2016), the literature on the sciencepractice gap in Ecology and Conservation addresses primarily the process of knowledge generation and the connection between science and practice, either through knowledge communication or integration (depending on the perspective). In this section, we thus present four main topics we believe disciplines such as Political Science and STS studies can contribute to the debate on the science-practice gap in Ecology and Conservation.

The first topic refers to several criticisms to the traditional model of decisionand policy-making, in which science is the sole provider of relevant information to a rational decision-maker, who access and evaluates such information, rank the benefits and costs of all possible actions, and arrives at a solution that maximizes the benefits (Collingridge \& Reeve, 1986; Albaek, 1995). Instead, more recent conceptualizations contemplate a complex decision-making context (reviewed in Albaek, 1995; Neilson, 2001; Nutley et al., 2007; Cairney, 2016), with different relevant factors besides science, such as political interests, social values, and feasibility of actions. In this complex context, decision-makers do not act fully rationally and are instead "boundedly rational", i.e., they cannot access all relevant information neither act upon it. They just make satisficing "good enough" decisions or make only incremental changes without considering science. Some conceptualizations even describe decisionmaking as chaotic and unpredictable, with solutions arising independently of problems and getting attached to them when opportunity arises. In this scenario, one can barely say decisions are being made. Also, because of diverse social interests that must be considered, political scientists and STS scholars have questioned the technocratic solution of science being the sole provider of information for going against democratic principles of diversity of opinions and debate (Collingridge \& Reeve, 1986; Albaek, 1995). In fact, solutions based on science may undermine the social identity and local knowledge of involved social groups (Wynne, 1996). 
The several criticisms to the rational model of decision-making emphasize the importance of understanding how decisions are made within an influential sociopolitical context and of considering diverse viewpoints. None of the identified perspectives in the ecological and conservation literature specifies how decisionmakers rely on science or are influenced by their context, and thus are committed to naïve views of decision-making (Oliver et al., 2014). However, the perspectives "One knowledge" and "One actor" seem to present a more rational view of the decisionmaking process by emphasizing only scientific knowledge should support decisionmaking, and neglecting the complexity of this process. Within the perspective "One knowledge", for instance, one of the most cited lower-level categories concerns scientific knowledge being outweighed by other factors ("Knowledge outweighed" within "Problems in knowledge use"), while the lower-level category that indicates a recognition of the complexity of decision-making ("Complexity of problems" within "General problems") was uncommon. In contrast, the perspective "Two knowledges" seems to take a more realistic view of decision-making by emphasizing decisionmakers have important knowledge - especially strategic knowledge (sensu Hulme, 2014) about what is legislatively, politically and administratively feasible - and by recognizing decision-making cannot be based solely on science. In this sense, the perspective "Two knowledges" may create paths for more democratic decision-making processes valuing other knowledges and social identities.

Secondly, the disciplines studying the role of science in decision-making propose the science-practice boundary is more diffuse then normally assumed. Current approaches from Political Science explain decision-making complexity by describing different networks influencing policy decisions (reviewed in Neilson, 2001; Nutley et al., 2007; Cairney, 2016). These networks are composed by diverse actors, such as policy-makers from different government levels, academics from diverse backgrounds, businesses representatives, consultants, activists, interest group leaders and the media. Thus, the relationship between science and practice does not necessarily occur directly between scientists and decision-makers (Nutley et al., 2007). Furthermore, STS studies emphasize the boundaries between science and policy are constantly negotiated in a political process (Jasanoff, 1987) and that science is embedded within society, as the construction of science involves not only scientists but rather all society (Sismondo, 2010). By emphasizing few (one or two) distinct types of actors, all perspectives on the 
science-practice gap encountered in the ecological and conservation literature are similar in disregarding these fuzzy boundaries between science and policy/practice. Only more recently, the consideration of science not as a separate entity but as immersed in society has entered the science-practice gap debate in Ecology and Conservation (Toomey et al., 2016).

The third contribution from disciplines such as STS studies and Political Science deals with the relevance of science for supporting decision-making. Some studies emphasize science, when brought to assist decision-making, actually complicates controversies by adding, to innate value conflicts, technical disagreements regarding scientific evidence (Collingridge \& Reeve, 1986; Sarewitz, 2004). As scientific knowledge is not an absolute truth, but empirically-based assertions subject to criticism, it is indeed liable to different interpretations filtered through each person's worldview (Collingridge \& Reeve, 1986). In the public process of decision-making, each side of the debate naturally finds in the accumulated body of scientific knowledge the evidence to support their position and technical arguments to criticize the interpretation of the opposing side (Collingridge \& Reeve, 1986; Sarewitz, 2004). In this sense, the uncertainty associated with scientific knowledge takes a new dimension when brought to public debate (Sarewitz, 2004), which has also been called ambiguity (Cairney, 2016). In contrast to uncertainty, ambiguity cannot be reduced by simply conducting more research (Cairney, 2016).

All identified perspectives of ecologists and conservation scientists on the science-practice gap similarly imply scientific knowledge can be used to assist decision-making, suggesting the discussion regarding the ambiguity of science when transposed to the public debate has not find its way into the ecological and conservation literature. However, the perspectives "One knowledge" and "Two knowledges" include a category of perceived causes related to "Cultural difficulties", which comprises different values and beliefs among scientists and decision-makers. The perspective "Two knowledges" also included the category "Epistemological difficulties", encompassing different conceptions of scientists and decision-makers regarding valid processes of knowledge generation. These cultural and epistemological differences may account for some of the different interpretations assigned to scientific knowledge when used to assist decision-making. More importantly, though, the perspective "Two knowledges" assumes a process of collaborative and sustained interactions among 
scientists, decision-makers and other stakeholders, which may be a path to deal with value differences in a more reflexive manner, by allowing the involved actors to be explicit about and negotiate their value positions.

Finally, the last topic refers to three main ways for scientific knowledge to be used in decision-making. Instrumental use occurs when a specific piece of scientific evidence is directly used to assist a specific decision or solve a clearly defined problem (Amara, 2004; Nutley et al., 2007), while symbolic use occurs when scientific knowledge is used to support and confirm an already established position (Amara, 2004). Conceptual use occurs when scientific findings, concepts or theoretical perspectives influence decision-makers' thinking or attitudes towards an issue, bringing new issues to the fore or turning "what were nonproblems into policy problems" (Weiss, 1979, p. 430). Although instrumental use is the most common view of science utilization (Nutley et al., 2007), symbolic and conceptual uses of science are more relevant than previously thought, being equally or more important than instrumental use (Amara, 2004). In a complex decision-making context, the main role of science may be to assist in developing arguments for already made positions (Collingridge \& Reeve, 1986; Albaek, 1995) or "enlighten" the process with concepts and perspectives (Weiss, 1979). However, because such indirect uses of science are harder to detect, and because we tend to focus on instrumental use, a perception of nonuse of science can prevail (Caplan, 1979; Weiss, 1979; Nutley et al., 2007).

None of the identified perspectives on the science-practice gap explicitly discuss these types of knowledge use, reinforcing the idea of a simplified view of science utilization. However, while some perspectives tend to focus more exclusively on instrumental use, others may potentially allow for alternative uses. The perspective "One actor" focuses on scientists solving specific problems in practice, thus emphasizing instrumental use. The "One knowledge" perspective similarly suggests a focus on instrumental use, as scientific knowledge is considered to be the sole provider of information to solve a specific problem. Within the category "Problems in knowledge use", for instance, scientific knowledge being selected by decision-makers to support their interests is perceived as a cause of the gap ("Knowledge selected"), indicating symbolic uses are viewed as a misuse of science, instead of a valid way for science to influence decision-making. In contrast, the perspective "Two knowledges" highlights an integrative process of collaboration and social learning among scientists 
and decision-makers, allowing for greater exchange of ideas and perceptions, and thus potentially fostering conceptual uses of science, although the concept is not made explicit.

Overall, considering these four insights from the disciplines studying the role of science in decision-making, the three identified perspectives on the science-practice gap in Ecology and Conservation represent similarly superficial views of decisionmaking, not accounting for the complexity of factors influencing decisions, the fuzzy boundaries between science and practice, the multitude of actors involved, the potential ambiguity of science in decision-making, or different types of knowledge use. However, in some aspects, the perspective "Two knowledges" seems to imply a more realistic view of decision-making by focusing on integrative co-production processes, which may allow for a more inclusive and democratic decision-making process, an explicit discussion of the ambiguity brought about by science and its underlying value positions, and diverse ways for science to be used.

\section{Implications for advancing the debate and fostering productive science-practice linkages in Ecology and Conservation}

The science-practice gap in Ecology and Conservation is perceived as a multifaceted problem with different causes arising from two main perspectives. The emphasis on a linear flow of knowledge from science to practice dominates the debate, which may result from the success of the evidence-based approach, especially within research traditions associated with mainstream conservation biology. There is therefore room for the expansion of a complementary approach for linking science and practice focusing on collaborative interactions and knowledge coproduction by scientists and decision-makers. However, this will require increased dialogue among research traditions within the ecological and conservation field that have historically been isolated from each other.

All identified perspectives of ecologists and conservation scientists take naïve views of decision-making processes. On the other hand, disciplines such as STS studies and Political Science do not give much attention to how scientific (or any kind of) knowledge is produced and/or reaches decision-makers. To gain a deeper understanding of the science-practice interface and conceive how productive links can be nurtured, the processes of decision-making and of knowledge production and 
communication/integration should be accounted for. The literature on the sciencepractice gap in Ecology and Conservation and in STS studies and Political Science may thus represent complementary views on the science-practice interface. From this standpoint, the integrative, collaborative process of knowledge coproduction - which amalgamates knowledge production, communication and use - represents an important contribution from Ecology and Conservation and other disciplines, especially Education. By allowing explicit debates and negotiations of different values and scientific interpretations through sustained interactions, this process assists the use of science together with other forms of knowledge in decision-making, without neglecting the complexity of factors and actors involved. It may then represent a path for a more effective science-practice linkage in general, supporting the incorporation of scientific knowledge in decision-making.

The differences between ecologists/conservation scientists and political scientists concerning prioritized processes (knowledge production/communication or decisionmaking, respectively) may reflect dissimilarities in the level of decision-making being addressed. Disciplines such as Political Science tend to focus on the national and federal levels of policy-making, while environmental and conservation problems considered in the literature frequently relate to more local problems (Agrawal \& Ostrom, 2006), such as protected areas' management or restoration of degraded land. At the macro-levels of policy-making, complexity may be greater and the ambiguity brought about by science may further complicate the debate, justifying the emphasis on understanding the intricate processes of decision-making. At the local and microlevel of frontline practice and management, there may be fewer factors to consider and a hindrance to effective decision-making may lie upon how knowledge is produced and communicated/integrated. By understanding how the different decision levels influence both the factors relevant for decision-making and the role science can play, we can arrive at a more comprehensive view of the science-practice interface. This suggests the importance of synthesis and interdisciplinary work across disciplines such as Ecology, Conservation, Political Science and STS studies.

However, for collaborative, integrative coproduction processes to be effective in incorporating scientific knowledge into decision-making, as well as for fostering interdisciplinary studies on the science-practice interface, scientists and decisionmakers should be trained and prepared to engage in dialogue with people from diverse 
backgrounds (Pardini et al., 2013). Hence, transforming undergraduate and graduate programs in Ecology and Conservation so that students gain contact with different disciplines, including courses on the sociopolitical dimension of decision-making (Cannon et al., 1996; Jacobson \& Duff, 1998; Toomey et al., 2016), and nurturing a stronger scientific education for those students who intend to work as decision-makers (Lewinsohn et al., 2015) should be a priority.

\section{CONCLUSIONS}

1. In the ecological and conservation literature, the science-practice gap is perceived as a multifaceted problem with a multitude of causes. Some of these causes are also recognized among scientists from other disciplines, such as Medicine, while others are specific to the ecological and conservation arena (e.g., mismatched spatial and temporal scales between scientific research and environmental problems).

2. The variety of perceived causes of the science-practice gap in Ecology and Conservation requires three general types of solutions: solutions eliminating or changing the causal factor (e.g., inadequate research questions), solutions requiring the recognition of, and then ways to deal with, the problem (e.g., scientific uncertainty), and solutions solving misconceptions (e.g., scientific knowledge being abstract).

3. The variety of perceived causes arise from three perspectives on the relationship between science and practice in Ecology and Conservation. The first assumes only scientific knowledge should support practice, establishing a unidirectional flow of knowledge from science to practice, while the second assumes both scientists and decision-makers should collaboratively contribute with knowledge to support practice. The last perspective in turn disregard decision-makers by assuming scientists should put their results into practice.

4. Although the identified perspectives parallel those in other disciplines, such as Medicine and Education, our findings suggest a mismatch between the prevalence of the linear view in the ecological and conservation literature and the historical tendency towards integrative views ascribing larger roles to decision-makers in other disciplines.

5. The prevalence of the linear perspective on the science-practice interface may be associated with the success of the evidence-based approach, while the integrative 
perspective seems primarily restricted to particular traditions, such as socio-ecological resilience and sustainability science.

6. The debate on the science-practice gap in Ecology and Conservation reflects an outdated view of decision-making, by not accounting for limits to human rationality, the complexity of actors, factors and interests influencing decisions, the fuzzy boundaries between science and practice, the potential ambiguity brought about by science and the different types of knowledge use.

7. However, while the linear perspective implies a more simplistic and rational view of decision-making, the integrative perspective can potentially account for more inclusive and democratic decision-making processes, allowing for explicit discussions of values and scientific interpretations, and for multiple types of science use.

8. A more productive relationship between science and practice in Ecology and Conservation may be achieved by increasing dialogue among different research traditions within the field, integrating a collaborative coproduction process within decision-making, creating interdisciplinary research programs across Ecology, Conservation, STS and Political Science that consider different decision-making levels, and transforming undergraduate and graduate courses to train both scientists and decision-makers to engage with people from diverse backgrounds.

\section{REFERENCES}

ADAMS, W.M. \& SANDBRooK, C. (2013) Conservation, evidence and policy. Oryx 47, $329-335$.

Agrawal, A. \& Ostrom, E. (2006) Political Science and Conservation Biology: a Dialog of the Deaf. Conservation Biology 20, 681-682.

AlBAEK, E. (1995) Between knowledge and power: utilization of social science in public policy making. Policy Sciences 28, 79-100.

Aldunce, P., Bórquez, R., Adler, C., Blanco, G. \& Garreaud, R. (2016) Unpacking Resilience for Adaptation: Incorporating Practitioners' Experiences through a Transdisciplinary Approach to the Case of Drought in Chile. Sustainability 8, 905.

Amara, N. (2004) New Evidence on Instrumental, Conceptual, and Symbolic Utilization of University Research in Government Agencies. Science Communication 26, 75-106.

ANDERSON, T.R. (2007) Bridging the educational research teaching practice gap. Biochemistry and Molecular Biology Education 35, 465-470. 
BAINBRIDGE, I. (2014) How can ecologists make conservation policy more evidence based? Ideas and examples from a devolved perspective. Journal of Applied Ecology 51, 1153-1158.

Barbour, M.T., Poff, N.L., Norris, R.H. \& Allan, J.D. (2008) Perspective: communicating our science to influence public policy. Journal of the North American Benthological Society 27, 562-569.

BARMUTA, L.A., LinKE, S. \& TURAK, E. (2011) Bridging the gap between 'planning' and 'doing' for biodiversity conservation in freshwaters. Freshwater Biology 56, $180-195$.

Barnosky, A.D., Hadly, E.A., Bascompte, J., Berlow, E.L., Brown, J.H., Fortelius, M., Getz, W.M., Harte, J., Hastings, A., Marquet, P.A., Martinez, N.D., Mooers, A., Roopnarine, P., Vermeij, G., Williams, J.W., et al. (2012) Approaching a state shift in Earth's biosphere. Nature 486, 52-58.

Baxter, G., Hockings, M., CArter, R. \& Beeton, R. (1999) Trends in wildlife management and the appropriateness of Australian university training. Conservation Biology 13, 842-849.

Bernard, H.R. \& RyAn, G.W. (2010) Analyzing Qualitative Data: Systematic Approaches. Sage, Los Angeles.

Bero, L.A., Grilli, R., Grimshaw, J.M., Harveym, E., OXMAN, A.D. \& Thomson, M.A. (1998) Getting Research Findings into Practice: Closing the Gap between Research and Practice: An Overview of Systematic Reviews of Interventions to Promote the Implementation of Research Findings. British Medical Journal 317, 465-468.

Born, J., Boreux, V. \& LAweS, M.J. (2009) Synthesis: Sharing Ecological Knowledge-The Way Forward. Biotropica 41, 586-588.

Bradley, E.H., CURry, L.A. \& Devers, K.J. (2007) Qualitative data analysis for health services research: developing taxonomy, themes, and theory. Health services research $\mathbf{4 2}, 1758-1772$.

BRADSHAW, G.A. \& BORCHERS, J.G. (2000) Uncertainty as information: Narrowing the science-policy gap. Conservation Ecology 4.

Braithwaite, R. (1955) Scientific Explanation, a Study of the Function of Theory, Probability and Law in Science. Cambridge University Press, Cambridge.

Brandt, P., Ernst, A., Gralla, F., Luederitz, C., LAng, D.J., Newig, J., Reinert, F., AbSON, D.J. \& vON Wehrden, H. (2013) A review of transdisciplinary research in sustainability science. Ecological Economics 92, 1-15.

BroekKamp, H. \& Hout-Wolters, B. VAN (2007) The gap between educational research and practice: A literature review, symposium, and questionnaire. Educational Research and Evaluation 13, 203-220.

Burger, J.R., Allen, C.D., Brown, J.H., Burnside, W.R., Davidson, A.D., Fristoe, T.S., Hamilton, M.J., Mercado-Silva, N., Nekola, J.C., OKie, J.G. \& Zuo, W. (2012) The Macroecology of Sustainability. PLoS Biology 10, e1001345. 
Butchart, S.H., Walpole, M., Collen, B., van Strien, A., Scharlemann, J.P., Almond, R.E., Baillie, J.E., Bomhard, B., Brown, C., Bruno, J., CArpenter, K.E., CARr, G.M., ChAnson, J., ChENERY, A.M., Csirke, J., et al. (2010) Global biodiversity: indicators of recent declines. Science 328, 1164-1168.

CABIN, R.J. (2007) Science-driven restoration: A square grid on a round earth? Restoration Ecology 15, 1-7.

Cabin, R.J., Clewell, A., Ingram, M., McDonald, T. \& Temperton, V. (2010) Bridging Restoration Science and Practice: Results and Analysis of a Survey from the 2009 Society for Ecological Restoration International Meeting. Restoration Ecology 18, 783-788.

Cairney, P. (2016) The Politics of Evidence-Based Policy Making. Palgrave Macmillan UK, London.

Cannon, J.R., Dietz, J.M. \& Dietz, L.A. (1996) Training conservation biologists in human interaction skills. Conservation Biology 10, 1277-1282.

Caplan, N. (1979) The two-communities theory and knowledge utilization. The American Behavioral Scientist 22, 459.

Carpenter, S., Folke, C., Scheffer, M. \& Westley, F. (2009) Resilience: accounting for the noncomputable. Ecology and Society 14.

CARPENTER, S.R. \& FolKe, C. (2006) Ecology for transformation. Trends in Ecology \& Evolution 21, 309-315.

Cash, D.W., Clark, W.C., Alcock, F., Dickson, N.M., Eckley, N., Guston, D.H., JÄGER, J. \& MitChELL, R.B. (2003) Knowledge systems for sustainable development. Proceedings of the National Academy of Sciences 100, 8086-8091.

ChSRF (2000) Health Services Research and... Evidence-Based Decision-Making. Canadian Health Services Research Foundation, Ottawa, Ontario.

Closs, S.J. \& CHEATER, F.M. (1994) Utilization of nursing research: culture, interest and support. Journal of Advanced Nursing 19, 762-773.

Collingridge, D. \& ReEve, C. (1986) Science speaks to power: the role of experts in policy making. St. Martin's Press, New York.

Cook, C.N., CArter, R.W., Fuller, R.A. \& Hockings, M. (2012) Managers consider multiple lines of evidence important for biodiversity management decisions. Journal of Environmental Management 113, 341-346.

Cook, C.N., Mascia, M.B., Schwartz, M.W., Possingham, H.P. \& Fuller, R.A. (2013) Achieving Conservation Science that Bridges the Knowledge-Action Boundary. Conservation Biology 27, 669-678.

Curtin, C.G. \& PARKer, J.P. (2014) Foundations of Resilience Thinking. Conservation Biology 28, 912-923.

DAYTON, P.K. (2003) The Importance of the Natural Sciences to Conservation: (An American Society of Naturalists Symposium Paper). The American Naturalist 162, 1-13. 
Dicks, L.V., WALSh, J. \& Sutherland, W.J. (2014) Organising evidence for environmental management decisions: a '4S'hierarchy. Trends in Ecology \& Evolution 29, 607-613.

Dovers, S.R., Norton, T.W. \& HANDMER, J.W. (1996) Uncertainty, ecology, sustainability and policy. Biodiversity and Conservation 5, 1143-1167.

Dramstad, W.E. \& FJellstad, W.J. (2012) Twenty-five years into 'our common future': are we heading in the right direction? Landscape Ecology 28, 1039-1045.

EL-HANI, C.N. (2006) Generalizações ecológicas. Oecologia Brasiliensis 10, 17-68.

EL-Hani, C.N. \& GReCA, I.M. (2013) ComPratica: A Virtual Community of Practice for Promoting Biology Teachers' Professional Development in Brazil. Research in Science Education 43, 1327-1359.

Esler, K.J., Prozesky, H., Sharma, G.P. \& McGeoch, M. (2010) How wide is the 'knowing-doing' gap in invasion biology? Biological Invasions 12, 4065-4075.

Eurobarometer (2014) Special Eurobarometer 419. Public perceptions of science, research and innovation. European Commission., TNS Opinion \& Social. Luxembourg.

Fazey, I., Salisbury, J.G., Lindenmayer, D.B., Maindonald, J. \& Douglas, R. (2004) Can methods applied in medicine be used to summarize and disseminate conservation research? Environmental Conservation 31, 190-198.

Finch, D.M. \& PATTON-Mallory, M. (1993) Closing the Gap between Research and Management. Status and Management of Neotropical Migratory Birds 229, 1216.

Foley, J.A., DeFries, R., Asner, G.P., Barford, C., Bonan, G., CArpenter, S.R., Chapin, F.S., Coe, M.T., Daily, G.C., GibBS, H.K., Helkowski, J.H., Holloway, T., Howard, E.A., Kucharik, C.J., Monfreda, C., et al. (2005) Global consequences of land use. Science 309, 570-574.

Gallo, L.A., Marchelli, P., Chauchard, L. \& Penalba, M.G. (2009) Knowing and Doing: Research Leading to Action in the Conservation of Forest Genetic Diversity of Patagonian Temperate Forests. Conservation Biology 23, 895-898.

Githiru, M., Lens, L., Adriaensen, F., Mwang'ombe, J. \& Matthysen, E. (2011) Using science to guide conservation: From landscape modelling to increased connectivity in the Taita Hills, SE Kenya. Journal for Nature Conservation 19, 263-268.

HADDAWAy, N. \& PUllin, A.S. (2013) Evidence-based conservation and evidenceinformed policy: a response to Adams \& Sandbrook. Oryx 47, 336-338.

Hall, J.A. \& Fleishman, E. (2010) Demonstration as a Means to Translate Conservation Science into Practice. Conservation Biology 24, 120-127.

Hegger, D., Lamers, M., Van ZeiJl-Rozema, A. \& Dieperink, C. (2012) Conceptualising joint knowledge production in regional climate change adaptation projects: success conditions and levers for action. Environmental Science \& Policy 18, 52-65. 
Huberman, M. (1994) Research utilization: The state of the art. Knowledge and Policy 7, 13-33.

Hulme, P.E. (2014) Bridging the knowing-doing gap: know-who, know-what, knowwhy, know-how and know-when. Journal of Applied Ecology 51, 1131-1136.

Jacobson, S.K. \& DUFF, M.D. (1998) Training idiot savants: the lack of human dimensions in conservation biology. Conservation Biology 12, 263-267.

JaSAnoff, S. (1987) Contested Boundaries in Policy-Relevant Science. Social Studies of Science 17, 195-230.

Jones, A.C., Mead, A., Kaiser, M.J., Austen, M.C.V., Adrian, A.W., Auchterlonie, N.A., Black, K.D., Blow, L.R., Bury, C., Brown, J.H., Burnell, G.M., Connolly, E., Dingwall, A., Derrick, S., Eno, N.C., et al. (2015) Prioritization of knowledge needs for sustainable aquaculture: a national and global perspective. Fish and Fisheries 16, 668-683.

KNIGHT, A.T. \& Cowling, R.M. (2006) Into the thick of it: bridging the researchimplementation gap in the Thicket Biome through the Thicket Forum. South African Journal of Science 102, 406-408.

Knight, A.T., Cowling, R.M., Rouget, M., Balmford, A., Lombard, A.T. \& CAMPBELL, B.M. (2008) Knowing but not doing: Selecting priority conservation areas and the research-implementation gap. Conservation Biology 22, 610-617.

KRIPPENDORFF, K. (2004) Reliability in content analysis: Some common misconceptions and recommendations. Human Communication Research 30, 411-433.

laplane, M., Badaró, A., Falcão, D., Moreira, I. de C., Castelfranchi, Y., Rizzo, F., Oliveira, I. DE, Paiva, M. \& CARriJo, T. (2015) Percepção pública da ciência e tecnologia 2015 - Ciência e tecnologia no olhar dos brasileiros. Centro de Gestão e Estudos Estratégicos, Brasília.

VAN LAteSteIJN, H.C. (1998) A policy perspective on land use changes and risk assessment. Agriculture Ecosystems \& Environment 67, 289-297.

Lauber, T.B., Stedman, R.C., Decker, D.J. \& Knuth, B.A. (2011) Linking Knowledge to Action in Collaborative Conservation. Conservation Biology 25, 1186-1194.

Lave, J. \& Wenger, E. (1991) Situated Learning: Legitimate Peripheral Practice. Cambridge University Press, Cambridge, UK.

Lewinsohn, T.M., Attayde, J.L., Fonseca, C.R., Ganade, G., Jorge, L.R., Kollmann, J., Overbeck, G.E., Prado, P.I., Pillar, V.D., PopP, D., DA Rocha, P.L.B., Silva, W.R., Spiekermann, A. \& Weisser, W.W. (2015) Ecological literacy and beyond: Problem-based learning for future professionals. Ambio 44, 154-162.

LinKLATER, W.L. (2003) Science and management in a conservation crisis: A case study with rhinoceros. Conservation Biology 17, 968-975. 
LUBCHENCO, J. (1998) Entering the century of the environment: a new social contract for science. Science 279, 491-497.

MAtTSOn, D.J., BYRD, K.L., Rutherford, M.B., Brown, S.R. \& ClARK, T.W. (2006) Finding common ground in large carnivore conservation: mapping contending perspectives. Environmental Science \& Policy 9, 392-405.

MCCleERY, R.A., LOPEZ, R.R. \& SILVY, N.J. (2007) Transferring research to endangered species management. Journal of Wildlife Management 71, 21342141.

MCInTYRe, D. (2005) Bridging the gap between research and practice. Cambridge Journal of Education 35, 357-382.

MEA (2005) Ecosystems and Human Well-being: Synthesis. Millenium Ecosystem Assessment, Washington, DC.

MuRPHY, S.C. \& KAEDING, B. (1998) Fishing bridge: 25 years of controversy regarding grizzly bear management in Yellowstone National Park. Ursus, 385-393.

NASEM (2015) Does the public trust science? Trust and confidence at the interfaces of the life sciences and society: a workshop summary. National Academies of Science, Engineering and Medicine, Washington, DC.

NeILson, S. (2001) Knowledge Utilization and Public Policy Processes: A Literature Review. IDRC.

Nutley, S.M., Walter, I. \& DAVIES, H.T.O. (2007) Using Evidence: How research can inform public services. Bristol. UK.

OAtes, K.K. (2013) The Importance of Basic Research. The Huffington Post. Http://www.huffingtonpost.com/karen-kashmanian-oates-phd/science-rolemodels_b_2821942.html [accessed 20 February 2016].

Oliver, K., LORENC, T. \& INNVAER, S. (2014) New directions in evidence-based policy research: a critical analysis of the literature. Health Research Policy and Systems 12,34 .

Pardini, R., Rocha, P.L.B., El-Hani, C. \& Pardini, F. (2013) Challenges and opportunities for bridging the research-implementation gap in ecological science and management in Brazil. In Conservation Biology: Voices from the Tropics pp. 77-95.

PEUHKURI, T. (2002) Knowledge and interpretation in environmental conflict Fish farming and eutrophication in the Archipelago Sea, SW Finland. Landscape and Urban Planning 61, 157-168.

Polasky, S., Carpenter, S.R., Folke, C. \& Keeler, B. (2011) Decision-making under great uncertainty: environmental management in an era of global change. Trends in Ecology \& Evolution 26, 398-404.

PREGERNIG, M. (2014) Framings of science-policy interactions and their discursive and institutional effects: examples from conservation and environmental policy. Biodiversity and Conservation 23, 3615-3639. 
Pullin, A.S. \& KNight, T.M. (2001) Effectiveness in Conservation Practice: Pointers from Medicine and Public Health. Conservation Biology 15, 50-54.

Pullin, A.S. \& KNIGHT, T.M. (2003) Support for decision making in conservation practice: an evidence-based approach. Journal for Nature Conservation 11, 8390 .

Pullin, A.S. \& KNIGHT, T.M. (2005) Assessing conservation management's evidence base: a survey of management-plan compilers in the United Kingdom and Australia. Conservation Biology 19, 1989-1996.

Pullin, A.S., Knight, T.M., Stone, D.A. \& Charman, K. (2004) Do conservation managers use scientific evidence to support their decision-making? Biological Conservation 119, 245-252.

Raymond, C.M., Fazey, I., Reed, M.S., Stringer, L.C., Robinson, G.M. \& Evely, A.C. (2010) Integrating local and scientific knowledge for environmental management. Journal of Environmental Management 91, 1766-1777.

Reyers, B., Roux, D.J., Cowling, R.M., Ginsburg, A.E., Nel, J.L. \& O’ FArRell, P. (2010) Conservation planning as a transdisciplinary process. Conservation Biology 24, 957-965.

Rigueira, D.M.G., Coutinho, S.L., Pinto-Leite, C.M., Sarno, V.L.C., Estavillo, C., Campos, S., Dias, V.S. \& Chastinet, C. DE B. E A. (2013) Perda de habitat, leis ambientais e conhecimento científico: proposta de critérios para a avaliação dos pedidos de supressão de vegetação. Caititu 1, 21-42.

Roux, D.J., Rogers, K.H., Biggs, H.C., Ashton, P.J. \& Sergeant, A. (2006) Bridging the science-management divide: Moving from unidirectional knowledge transfer to knowledge interfacing and sharing. Ecology and Society 11.

SAREWITZ, D. (2004) How science makes environmental controversies worse. Environmental Science \& Policy 7, 385-403.

SEAVy, N.E. \& Howell, C.A. (2010) How can we improve information delivery to support conservation and restoration decisions? Biodiversity and Conservation 19, 1261-1267.

Shackleton, C.M., Cundill, G. \& Knight, A.T. (2009) Beyond Just Research: Experiences from Southern Africa in Developing Social Learning Partnerships for Resource Conservation Initiatives. Biotropica 41, 563-570.

ShANLEY, P. \& LÓPEZ, C. (2009) Out of the loop: why research rarely reaches policy makers and the public and what can be done. Biotropica 41, 535-544.

ShaW, J.D., WiLson, J.R.U. \& Richardson, D.M. (2010) Initiating dialogue between scientists and managers of biological invasions. Biological Invasions 12, 4077 4083.

Sismondo, S. (2010) An introduction to science and technology studies2nd ed. WileyBlackwell, Chichester, West Sussex, U.K. 
Sunderland, T., Sunderland-Groves, J., Shanley, P. \& CAmpbell, B. (2009) Bridging the Gap: How Can Information Access and Exchange Between Conservation Biologists and Field Practitioners be Improved for Better Conservation Outcomes? Biotropica 41, 549-554.

Sutherland, W.J., Adams, W.M., Aronson, R.B., Aveling, R., Blackburn, T.M., Broad, S., Ceballos, G., Côté, I.M., Cowling, R.M., Da Fonseca, G. A B., Dinerstein, E., Ferraro, P.J., Fleishman, E., Gascon, C., Hunter, M., et al. (2009) One hundred questions of importance to the conservation of global biological diversity. Conservation Biology 23, 557-567.

Sutherland, W.J. \& Pullin, A.S. (2004) The need for evidence-based conservation. Trends in Ecology \& Evolution 19, 305-308.

ToOmey, A.H., KNight, A.T. \& BArLow, J. (2016) Navigating the Space Between Research and Implementation in Conservation. Conservation Letters.

Tress, B., Tress, G. \& Fry, G. (2005) Defining concepts and the process of knowledge production in integrative research. In Tress, B., Tress, G., Fry, G. \& OPDAM, P. (2005) From landscape research to landscape planning: aspects of integration, education and application pp. 13-26. Springer: Heidelberg, Germany.

VANDERLINDE, R. \& VAN BRAAK, J. (2010) The gap between educational research and practice: views of teachers, school leaders, intermediaries and researchers. British Educational Research Journal 36, 299-316.

WADDELL, C. (2002) So much research evidence, so little dissemination and uptake: mixing the useful with the pleasing. Evidence Based Nursing 5, 38-40.

WALSH, J.C. (2015) Barriers and solutions to implementing evidence-based conservation. PhD Thesis, University of Cambridge, Cambridge, UK.

Walsh, J.C., Dicks, L.V. \& Sutherland, W.J. (2015) The effect of scientific evidence on conservation practitioners' management decisions. Conservation Biology 29, 88-98.

Weber, M. (1999) The aim and structure of ecological theory. Philosophy of Science 66, 71-93.

WeISs, C.H. (1979) The many meanings of research utilization. Public Administration Review, 426-431.

Wenger, E. (1998) Communities of Practice: Learning, Meaning, and Identity. Cambridge University Press, Cambridge, UK.

WENGER, E. (2011) Communities of practice: A brief introduction.

Whitmer, A., Ogden, L., Lawton, J., Sturner, P., Groffman, P.M., Schneider, L., Hart, D., Halpern, B., Schlesinger, W., Raciti, S., Bettez, N., Ortega, S., Rustad, L., Pickett, S.T. \& Killilea, M. (2010) The engaged university: providing a platform for research that transforms society. Frontiers in Ecology and the Environment 8, 314-321. 
WYNNE, B. (1996) Misunderstood misunderstandings: social identities and public uptake of science. In Misunderstanding science? The public reconstruction of science and technology pp. 19-46. Cambridge University Press.

Young, K.D. \& VAN AARDE, R.J. (2011) Science and elephant management decisions in South Africa. Biological Conservation 144, 876-885. 


\section{SUPPORTING INFORMATION}

\section{Appendix S1 - Additional information on the bibliographic search.}

\section{Database scope}

We conducted our bibliographic search in the "Web of Science Core Collection" (https://apps.webofknowledge.com/) because it is one of the largest databases available in the Web of Science platform and it offers helpful search tools allowing refinement per journal area. This allowed us to focus the search on the perceived causes of the science-practice gap in Ecology and Conservation, excluding the abundant literature on this subject in other disciplines.

Journals allocated to the Ecology category by Thomson Reuters (see Scope notes in http://ip-science.thomsonreuters.com/mjl/scope/) covers research related to interactions between organisms and their environments in general or devoted to particular ecological systems, including "ecological economics, ecological engineering, ecotoxicology, ecological modeling, evolutionary ecology, biogeography, chemical ecology, marine ecology, wildlife research, microbial ecology, molecular ecology, and population ecology". The Biodiversity Conservation category covers journals on conservation management of species and ecosystems, including "conservation ecology, biological conservation, paleobiology, natural history and the natural sciences".

\section{Criteria for selecting the articles}

1. The article should refer to a gap between science and practice as defined in the main text, i.e., involving a distance between science, on one side, and action and decision-making of public, private and non-profit (NGOs) organizations, on the other side. This criterion excluded articles discussing a gap between the planning and implementation of an action, since both processes are related to practice. It also excluded articles discussing integration of scientific knowledge with local knowledge, as this does not involve the organizational level of practice. Lastly, this criterion also excluded articles reviewing scientific knowledge and recommending possible applications, but without discussing barriers to the use of these recommendations in practice. However, we selected articles that proposed protocols or tools to support 
decision-making and practical actions of organizations while simultaneously discussing barriers for its use in practice (see criterion 3).

2. The article should refer to a gap involving ecological and conservation science and the practice related to the development of environmental policies and/or the conservation or management of biodiversity and of ecological and socio-ecological systems. This criterion excluded articles referring, for example, to a gap between the science of climate modeling and the practice related to the modifications in economic systems.

3. The article should discuss factors causing a distance between science and practice, even if this was not the paper's main objective. This criterion excluded articles that only reported the existence of a gap between science and practice or ways to overcome the gap (e.g., presenting successful case studies), but that did not explain what could have originally caused the reported gap between science and practice. This criterion also excluded articles discussing the importance of the science-practice gap for the current environmental crisis, but that also did not present causes of the gap.

4. We also excluded opening editorials of special sections on the science-practice gap, because their content was already represented in the selected articles from the special sections. 
Appendix S2 - Organization of terms and connectors of the search string used in the "Web of Science Core Collection"

\begin{tabular}{|c|c|c|}
\hline TERMS SCIENCE & NEAR/5 & TERMS GAP \\
\hline $\begin{array}{l}\text { Research* } \\
\text { OR Theor* } \\
\text { OR Scien* } \\
\text { OR Know* } \\
\text { OR Planning* } \\
\text { OR Academ* } \\
\text { OR Universit* } \\
\text { OR Evidenc* }\end{array}$ & \begin{tabular}{|l|} 
TERMS PRACTICE \\
Oractic* \\
OR Implement* \\
OR Doing* \\
OR Act* \\
OR Polic* \\
OR Manag* \\
OR “Decision-mak*” \\
OR Technic* \\
\end{tabular} & $\begin{array}{l}\text { Gap* } \\
\text { OR Distanc* } \\
\text { OR Divid* } \\
\text { OR Mismatch* } \\
\text { OR Link* } \\
\text { OR Bridg* } \\
\text { OR Connect* } \\
\text { OR Interact* } \\
\text { OR Integrat* } \\
\text { OR Exchang* } \\
\text { OR Transfer* } \\
\text { OR Approximat* }\end{array}$ \\
\hline \multicolumn{3}{|c|}{ OR } \\
\hline
\end{tabular}

Figure S1. Organization of terms and connectors of the search string used in the "Web of Science Core Collection". Boxes represent the parentheses used. The connector NEAR/5 searches for terms that are at most five words from each other. 


\section{Appendix S3 - List of the 122 articles selected for the review of perceived causes of the science-practice gap in Ecology and Conservation.}

Table S1. List of the 122 articles selected for the review of perceived causes of the science-practice gap in Ecology and Conservation. $\mathrm{N}=$ non-priority articles; $\mathrm{P}=$ priority articles. Codes for the categories of perceived causes of the science-practice gap in Ecology and Conservation are those found in Appendix S6.

\begin{tabular}{|c|c|c|c|}
\hline Article reference & Priority & Year & Included category of perceived causes \\
\hline $\begin{array}{l}\text { Addison, P. F. E., Rumpff, L., Bau, S. S., Carey, J. M., Chee, Y. E., Jarrad, F. C., } \\
\text { McBride, M. F., \& Burgman, M. A. (2013). Practical solutions for making models } \\
\text { indispensable in conservation decision-making. Diversity and Distributions, 19(5-6), } \\
490-502 \text {. }\end{array}$ & $\mathrm{N}$ & 2013 & $\begin{array}{l}1000,1100,1110,1116,1119,1120,1121,1122,1125,1126,1128, \\
1129,1129.5,1200,1210,1211,1212,1220,1222,1300,1310, \\
1311,1312,1330,1500,1510,1520,1522,2000,2100,2110,2130, \\
2150,2151,2153\end{array}$ \\
\hline $\begin{array}{l}\text { Albert, C., Hauck, J., Buhr, N., \& von Haaren, C. (2014). What ecosystem services } \\
\text { information do users want? Investigating interests and requirements among landscape } \\
\text { and regional planners in Germany. Landscape Ecology, 29(8), 1301-1313. }\end{array}$ & $\mathrm{P}$ & 2014 & $\begin{array}{l}1000,1100,1110,1111,1120,1124,1126,1130,1132,1200,1210 \text {, } \\
1212,1220,1221,1222,1300,1310,1312\end{array}$ \\
\hline $\begin{array}{l}\text { Anderson, P. (2014). PRACTITIONER'S PERSPECTIVE: Bridging the gap between } \\
\text { applied ecological science and practical implementation in peatland restoration. Journal } \\
\text { of Applied Ecology, 51(5), 1148-1152. }\end{array}$ & $\mathrm{P}$ & 2014 & $\begin{array}{l}1000,1100,1110,1112,1113,1114,1118,1119,1120,1124,1125, \\
1129,1130,1131,1200,1210,1211,1220,1221,1222,1400,1410, \\
1500,1520,1521,2000,2100,2120\end{array}$ \\
\hline $\begin{array}{l}\text { Antrop, M. (2001). The language of landscape ecologists and planners - A comparative } \\
\text { content analysis of concepts used in landscape ecology. Landscape and Urban Planning, } \\
55(3), 163-173 \text {. }\end{array}$ & $\mathrm{P}$ & 2001 & $1000,1119,1200,1210,1212,1500,1510,2000,2100,2130$ \\
\hline $\begin{array}{l}\text { Arkema, K. K., Abramson, S. C., \& Dewsbury, B. M. (2006). Marine ecosystem-based } \\
\text { management: from characterization to implementation. Frontiers in Ecology and the } \\
\text { Environment, 4(10), 525-532. }\end{array}$ & $\mathrm{N}$ & 2006 & $\begin{array}{l}1000,1100,1120,1121,1130,1131,1132,1200,1210,1212,1220 \text {, } \\
1222\end{array}$ \\
\hline $\begin{array}{l}\text { Armstrong, D. P., \& McCarthy, M. A. (2007). Big Decisions and Sparse Data: Adapting } \\
\text { Scientific Publishing to the Needs of Practical Conservation. Avian Conservation and } \\
\text { Ecology, 2(2). }\end{array}$ & $\mathrm{P}$ & 2007 & $\begin{array}{l}1000,1100,1110,1112,1200,1220,1221,1400,1410,1500,1510, \\
1520,1521,2000,2100,2140,2141\end{array}$ \\
\hline $\begin{array}{l}\text { Bainbridge, I. (2014). PRACTITIONER'S PERSPECTIVE: How can ecologists make } \\
\text { conservation policy more evidence based? Ideas and examples from a devolved } \\
\text { perspective. Journal of Applied Ecology, 51(5), 1153-1158. }\end{array}$ & $\mathrm{P}$ & 2014 & $\begin{array}{l}1000,1200,1210,1212,1220,1221,1222,1300,1310,1312,1500 \text {, } \\
1520,1522\end{array}$ \\
\hline $\begin{array}{l}\text { Barbour, M. T., Poff, N. L., Norris, R. H., \& Allan, J. D. (2008). Perspective: } \\
\text { communicating our science to influence public policy. Journal of the North American } \\
\text { Benthological Society, 27(3), 562-569. }\end{array}$ & $\mathrm{P}$ & 2008 & $\begin{array}{l}1000,1100,1120,1125,1200,1210,1211,1212,1220,1221,1222, \\
1300,1330,1500,1510,1520,1522,1530,1532,1540\end{array}$ \\
\hline
\end{tabular}


Bergsten, A., \& Zetterberg, A. (2013). To model the landscape as a network: A practitioner's perspective. Landscape and Urban Planning, 119, 35-43.

Born, J., Boreux, V., \& Lawes, M. J. (2009). Synthesis: Sharing Ecological KnowledgeThe Way Forward. Biotropica, 41(5), 586-588.

Bowd, R., Quinn, N., Kotze, D. C., Hay, D. G., \& Mander, M. (2012). The Identification of Potential Resilient Estuary-based Enterprises to Encourage Economic Empowerment in South Africa: a Toolkit Approach. Ecology and Society, 17(3).

Bradshaw, G. A., \& Borchers, J. G. (2000). Uncertainty as information: Narrowing the science-policy gap. Conservation Ecology, 4(1).

Brandt, P., Ernst, A., Gralla, F., Luederitz, C., Lang, D. J., Newig, J., Reinert, F., Abson, D. J., \& von Wehrden, H. (2013). A review of transdisciplinary research in sustainability science. Ecological Economics, 92, 1-15.

Cabin, R. J., Clewell, A., Ingram, M., McDonald, T., \& Temperton, V. (2010). Bridging Restoration Science and Practice: Results and Analysis of a Survey from the 2009 Society for Ecological Restoration International Meeting. Restoration Ecology, 18(6), 783-788.

Cabin, R. J. (2007). Science-driven restoration: A square grid on a round earth? Restoration Ecology, 15(1), 1-7.

Castilla, J. C. (2000). Roles of experimental marine ecology in coastal management and conservation. Journal of Experimental Marine Biology and Ecology, 250(1-2), 3-21.

Castillo, A., Torres, A., Velazquez, A., \& Bocco, G. (2005). The use of ecological science by rural producers: A case study in Mexico. Ecological Applications, 15(2), $745-756$.

Cook, C. N., Mascia, M. B., Schwartz, M. W., Possingham, H. P., \& Fuller, R. A. (2013). Achieving Conservation Science that Bridges the Knowledge-Action Boundary. Conservation Biology, 27(4), 669-678.
2013

$1000,1100,1120,1129,1130,1131,1132,1200,1210,1212,1220$ $1221,1222,1300,1310,1312,1320,1330,1500,1520,1523$

$\mathrm{P}$

$20091000,1100,1110,1111,1113,1120,1123,1200,1220,1221,1500$ $1520,1521,2000,2100,2110,2140,2142$

$20121000,1100,1110,1113,1130,1131,1132$

2000

$1000,1100,1120,1125,1200,1220,1222,1300,1310,1311,1312$, 1500,1510

$\mathrm{N}$

$20132000,2100,2110,2130,2140,2141$

$1000,1100,1110,1112,1113,1114,1130,1131,1200,1210,1211$, $20101212,1300,1310,1311,1400,1410,1500,1510,2000,2100,2120$ 2130

$1000,1100,1110,1114,1118,1120,1121,1129,1130,1131,1300$ $20071310,1311,1500,1510,1520,1521,1523,1540,2000,2100,2120$ 2140,2141

$20001000,1300,1330,2160$

$1000,1100,1110,1112,1120,1121,1130,1132,1200,1210,1212$, $20051300,1310,1311,1312,1330,1500,1510,1520,1521,1523,1524$, 2000, 2100, 2140, 2141, 2144

$1000,1100,1110,1112,1114,1116,1117,1118,1120,1121,1126$ $20131129,1129.5,1200,1220,1221,1222,1300,1310,1311,1312$, $1500,1510,1520,1521,1522,1540,2000,2100,2120$ 


\section{Priority Year}

Courter, J. R. (2012). Graduate students in conservation biology: Bridging the researchimplementation gap. Journal for Nature Conservation, 20(1), 62-64.

Crist, P. J., Kohley, T. W., \& Oakleaf, J. (2000). Assessing land-use impacts on biodiversity using an expert systems tool. Landscape Ecology, 15(1), 47-62.

Dale, V. H. (1998). Managing forests as ecosystems: A success story or a challenge ahead? In Successes, Limitations, and Frontiers in Ecosystem Science (pp. 50-68). New York: Springer.

Davies, A. L., Colombo, S., Hanley, N., \& Thompson, D. (2014). Improving the application of long-term ecology in conservation and land management. Journal of Applied Ecology, 51(1), 63-70.

DeSimone, S. A. (2013). Restoration and Science: A Practitioner/Scientist's View from Rare Habitat Restoration at a Southern California Preserve. Restoration Ecology, 21(2), $149-152$.

Dettman, C. L., \& Mabry, C. M. (2008). Lessons Learned about Research and Management: A Case Study from a Midwest Lowland Savanna, USA. Restoration Ecology, 16(4), 532-541.

Dicks, L. V., Hodge, I., Randall, N. P., Scharlemann, J. P. W., Siriwardena, G. M., Smith, H. G., Smith, R. K., \& Sutherland, W. J. (2014). A Transparent Process for "Evidence-Informed” Policy Making. Conservation Letters, 7(2), 119-125.

Dovers, S. R., Norton, T. W., \& Handmer, J. W. (1996). Uncertainty, ecology, sustainability and policy. Biodiversity and Conservation, 5(10), 1143-1167.

Dramstad, Wenche E., \& Fjellstad, W. J. (2012). Twenty-five years into "our common future": are we heading in the right direction? Landscape Ecology, 28(6), 1039-1045.

Dramstad, W. E., \& Fjellstad, W. J. (2011). Landscapes: Bridging the gaps between science, policy and people. Landscape and Urban Planning, 100(4), 330-332.

(a)

$\mathrm{N}$

2012

$1000,1100,1110,1116,1120,1129,1200,1210,1211,1220,1221$,

$20001000,1100,1120,1125,1126,1130,1132,1200,1220,1221,1230$, $1300,1330,1500,1520,1523$

$19981000,1100,1110,1116,1130,1132,1200,1210,1211,1212$

$\mathrm{P}$

$\mathrm{P}$

$1000,1100,1110,1117,1118,1120,1125,1200,1220,1221,1500$, $1510,1520,1521,1523,2000,2100,2140,2141$

$1000,1100,1110,1111,1112,1117,1118,1120,1125,1126,1127$, $1130,1131,1132,1200,1210,1211,1212,1220,1221,1222,1300$, $1310,1312,1320,1330,1400,1420,1500,1510,1520,1521,1522$, 1540,1550

$1000,1100,1110,1113,1200,1210,1211,1212,1220,1221,1222$, $1500,1520,1521,1523,1550$

$20111000,1300,1330$ 
Drolet, D., Locke, A., Lewis, M. A., \& Davidson, J. (2014). User-friendly and evidencebased tool to evaluate probability of eradication of aquatic non-indigenous species. Journal of Applied Ecology, 51(4), 1050-1056.

Duchelle, A. E., Biedenweg, K., Lucas, C., Virapongse, A., Radachowsky, J., Wojcik, D. J., Londres, M., Bartels, W. L., ... Kainer, K. A. (2009). Graduate Students and Knowledge Exchange with Local Stakeholders: Possibilities and Preparation. Biotropica, 41(5), 578-585.

Durant, S. M., Bashir, S., Maddox, T., \& Laurenson, M. K. (2007). Relating long-term studies to conservation practice: The case of the Serengeti Cheetah Project. Conservation Biology, 21(3), 602-611.

Enengel, B., Muhar, A., Penker, M., Freyer, B., Drlik, S., \& Ritter, F. (2012). Coproduction of knowledge in transdisciplinary doctoral theses on landscape development-An analysis of actor roles and knowledge types in different research phases. Landscape and Urban Planning, 105(1-2), 106-117.

Esler, K. J., Prozesky, H., Sharma, G. P., \& McGeoch, M. (2010). How wide is the "knowing-doing" gap in invasion biology? Biological Invasions, 12(12), 4065-4075.

Eviner, V. T., \& Hawkes, C. V. (2008). Embracing Variability in the Application of Plant-Soil Interactions to the Restoration of Communities and Ecosystems. Restoration Ecology, 16(4), 713-729.

Finch, D. M., \& Patton-Mallory, M. (1993). Closing the Gap between Research and Management. Status and Management of Neotropical Migratory Birds, 229, 12-16.

Firth, P. L. (1998). Fresh water: Perspectives on the integration of research, education, and decision making. Ecological Applications, 8(3), 601-609.

Fitzgerald, L. A., \& Stronza, A. L. (2009). Applied Biodiversity Science: Bridging Ecology, Culture, and Governance for Effective Conservation. Interciencia, 34(8), 563570
$\mathrm{N}$

$20141000,1100,1120,1124,1130,1132,1200,1220,1221,1222,1400$ 1410 2009

$1000,1100,1110,1112,1200,1210,1211,2000,2100,2140,2141$ 2143

$1000,1100,1110,1112,1116,1117,1130,1131,1200,1210,1211$ $20071212,1220,1221,1222,1300,1310,1312,1330,1500,1510,1520$, 1522,1523

$20122000,2100,2140,2141,2143$

$20101000,1100,1110,1111,1112,1113,1116,1120,1121,1123,1200$ $1210,1212,1220,1221,1500,1520,1521,2000,2100,2140,2141$

$20081000,1100,1110,1114,1120,1124$

$1000,1100,1110,1112,1114,1116,1120,1129,1130,1131,1200$ $19931210,1212,1220,1221,1400,1420,1500,1510,2000,2100,2120$, 2130

$19981000,1100,1110,1111,1117,1120,1125,1129.5,1200,1220$ $1222,1300,1330,1500,1520,1521,1522,1523,2000,2100,2130$

$20091000,1100,1110,1111,1116,1200,1220,1222,1500,1520,1521$ 1522 
Flitcroft, R. L., Dedrick, D. C., Smith, C. L., Thieman, C. A., \& Bolte, J. P. (2009). Social Infrastructure to Integrate Science and Practice: the Experience of the Long Tom Watershed Council. Ecology and Society, 14(2).

Gallo, L. A., Marchelli, P., Chauchard, L., \& Penalba, M. G. (2009). Knowing and Doing: Research Leading to Action in the Conservation of Forest Genetic Diversity of Patagonian Temperate Forests. Conservation Biology, 23(4), 895-898.

Gawne, B., Price, A., Koehn, J. D., King, A. J., Nielsen, D. L., Meredith, S., Beesley, L., \& Vilizzi, L. (2012). A Bayesian Belief Network Decision Support Tool for Watering Wetlands to Maximise Native Fish Outcomes. Wetlands, 32(2), 277-287.

Githiru, M., Lens, L., Adriaensen, F., Mwang’ombe, J., \& Matthysen, E. (2011). Using science to guide conservation: From landscape modelling to increased connectivity in the Taita Hills, SE Kenya. Journal for Nature Conservation, 19(5), 263-268.

Gobster, P. H. (2014). Re-wilding Europe's traditional agricultural landscapes: Values and the link between science and practice. Landscape and Urban Planning, 126, 65-65.

Gosselin, F. (2008). Management on the basis of the best scientific data or integration of ecological research within management? Lessons learned from the Northern spotted owl saga on the connection between research and management in conservation biology. Biodiversity and Conservation, 18(4), 777-793.

Griffiths, R. A. (2004). Mismatches between conservation science and practice. Trends in Ecology \& Evolution, 19(11), 564-565.

Groffman, P. M., Stylinski, C., Nisbet, M. C., Duarte, C. M., Jordan, R., Burgin, A., Previtali, M. A., \& Coloso, J. (2010). Restarting the conversation: challenges at the interface between ecology and society. Frontiers in Ecology and the Environment, 8(6), 284-291.

Guisan, A., Tingley, R., Baumgartner, J. B., Naujokaitis-Lewis, I., Sutcliffe, P. R., Tulloch, A. I. T., Regan, T. J., Brotons, L., ... Buckley, Y. M. (2013). Predicting species distributions for conservation decisions. Ecology Letters, 16(12), 1424-1435.
$\mathrm{N}$

$20092000,2100,2110$

$1000,1100,1110,1116,1200,1210,1211,3000$

$\mathrm{N}$

2012

$1000,1100,1120,1126,1130,1131,1132,1200,1210,1212,1220$, $1221,1222,1230,1313,2000,2100,2150,2151$

$20111000,1100,1110,1111,1300,1330$

$20141000,1100,1110,1111,1120,1127$

$20091000,1200,1210,1212,1220,1222,1300,1320,1500,1510$

$\mathrm{P}$

$20041000,1100,1110,1117,1130,1131$

$20101000,1200,1210,1212,1300,1310,1311,1320$

$1000,1100,1110,1112,1116,1120,1121,1127,1129,1130,1132$,
$1200,1220,1221,1222,1300,1310,1311,1400,1410,1500,1510$ 1524 
Habel, J. C., Gossner, M. M., Meyer, S. T., Eggermont, H., Lens, L., Dengler, J., \& Weisser, W. W. (2013). Mind the gaps when using science to address conservation concerns. Biodiversity and Conservation, 22(10), 2413-2427.

Hall, J. A., \& Fleishman, E. (2010). Demonstration as a Means to Translate Conservation Science into Practice. Conservation Biology, 24(1), 120-127.

Hecht, A., \& Parkin, M. J. (2008). Integrating research and management. Journal of Wildlife Management, 72(5), 1279-1280.

Hoban, S., Arntzen, J. W., Bertorelle, G., Bryja, J., Fernandes, M., Frith, K., Gaggiotti, O., Galbusera, P., ... Bruford, M. W. (2013). Conservation Genetic Resources for Effective Species Survival (ConGRESS): Bridging the divide between conservation research and practice. Journal for Nature Conservation, 21(6), 433-437.

Hulme, P. E. (2014). Bridging the knowing-doing gap: know-who, know-what, knowwhy, know-how and know-when. Journal of Applied Ecology, 51(5), 1131-1136.

Johnston, J., Volz, S., Bruce, K., Chipman, R., Luchsinger, J., McConnell, J., \& Owens, R. (1999). Information transfer for wildlife management. Wildlife Society Bulletin, 27(4), 1043-1049.

Jørgensen, D., Nilsson, C., Hof, A. R., Hasselquist, E. M., Baker, S., Chapin, F. S., Eckerberg, K., Hjältén, J., ... Meyerson, L. A. (2014). Policy Language in Restoration Ecology. Restoration Ecology, 22(1), 1-4.

Karl, J. W., Herrick, J. E., \& Browning, D. M. (2012). A Strategy for Rangeland Management Based on Best Available Knowledge and Information. Rangeland Ecology \& Management, 65(6), 638-646.

Kininmonth, S., Donovan, T., \& Edgar, S. (2003). Fusing scientific modelling with knowledge management systems. In Modsim 2003: International Congress on Modelling and Simulation (pp. 696-701). Nedlands: University of Western Australia.

Kirchhoff, M. D., Schoen, J. W., \& Franklin, T. M. (1995). A Model for Science-Based Conservation Advocacy - Tongass-National-Forest Case-History. Wildlife Society Bulletin, 23(3), 358-364.

$1000,1100,1110,1111,1112,1116,1120,1123,1126,1200,1210$ $1211,1212,1500,1510,1520,1521$

$1000,1100,1110,1111,1113,1116,1119,1120,1122,1124,1127$ $20101129,1200,1210,1212,1300,1310,1312,1500,1520,1521,2000$, 2100, 2130, 2150, 2151

$\mathrm{P}$

$20081000,1200,1210,1212,1230,1500,1510,1520,1521,1523$

$\mathrm{P}$

$\mathrm{P}$
2013

$1000,1100,1120,1127,1129,1130,1132,1200,1210,1211,1212$ $1220,1221,1222,1500,1510,1520,1521,1523,2000,2100,2110$

$1000,1100,1110,1111,1120,1121,1123,1124,1127,2000,2100$, $2120,2130,2140,2141,2150,2153$

$19991000,1200,1210,1211,1212,1220,1221$

$20141000,1100,1110,1111,1130,1132,1200,1210,1212,1533$

$20121000,1100,1110,1113,1120,1124,1200,1220,1221,2000,2100$ 2120,2160

$20031000,1100,1110,1115,1120,1126,1127,1200,1210,1212,1220$ $1221,1500,1520,1521$

$19951000,1200,1210,1211,1212,1220,1221,1300,1310,1311,1330$ $1500,1520,1521$ 
Klauer, B., Manstetten, R., Petersen, T., \& Schiller, J. (2013). The art of long-term thinking: A bridge between sustainability science and politics. Ecological Economics, 93, 79-84.

Knight, A. T., Cowling, R. M., \& Campbell, B. M. (2006). An operational model for implementing conservation action. Conservation Biology, 20(2), 408-419.

Knight, A. T., Cowling, R. M., Rouget, M., Balmford, A., Lombard, A. T., \& Campbell, B. M. (2008). Knowing but not doing: Selecting priority conservation areas and the research-implementation gap. Conservation Biology, 22(3), 610-617.

Knight, A. T., Cowling, R. M., Boshoff, A. F., Wilson, S. L., \& Pierce, S. M. (2011). Walking in STEP: Lessons for linking spatial prioritisations to implementation strategies. Biological Conservation, 144(1), 202-211.

Kroll, A. J. (2007). Integrating professional skills in wildlife student education. Journal of Wildlife Management, 71(1), 226-230.

Kueffer, C., Underwood, E., Hadorn, G. H., Holderegger, R., Lehning, M., Pohl, C., Schirmer, M., Schwarzenbach, R., ... Edwards, P. (2012). Enabling Effective Problemoriented Research for Sustainable Development. Ecology and Society, 17(4).

Latta, S. C. (2000). Making the leap from researcher to planner: Lessons from avian conservation planning in the Dominican Republic. Conservation Biology, 14(1), 132139.

Lauber, T. B., Stedman, R. C., Decker, D. J., \& Knuth, B. A. (2011). Linking Knowledge to Action in Collaborative Conservation. Conservation Biology, 25(6), 1186-1194.

Laurance, W. F., Koster, H., Grooten, M., Anderson, A. B., Zuidema, P. A., Zwick, S., Zagt, R. J., Lynam, A. J., ... Anten, N. P. R. (2012). Making conservation research more relevant for conservation practitioners. Biological Conservation, 153, 164-168.

Linklater, W. L. (2003). Science and management in a conservation crisis: A case study with rhinoceros. Conservation Biology, 17(4), 968-975.

$1000,1100,1110,1112,1114,1115,1116,1120,1122,1130,1132$ $1400,1410,2000,2100,2150,2151$

$1000,1100,1110,1112,1115,1116,1119,1120,1123,1500,1520$, $1521,1522,2000,2100,2130,2140,2141,3000$

$20111000,1100,1110,1111,1115,1116,1120,1122,1123,1130,1132$, $1213,1500,1520,1521,2000,2100,2110,3000$

$20071000,1100,1120,1128,1300,1330,1500,1510,2000,2100,2140$, $2142,2150,2152$

$1000,1100,1110,1111,1112,1118,1119,1120,1129,1200,1210$, $20121212,1220,1221,1222,1300,1320,1500,1510,1520,1521,1522$, 2000, 2100, 2150, 2151

$20001000,1100,1130,1131,1200,1210,1212,1220,1221,1500,1520$ $1522,1524,2000,2100,2110$

$1000,1100,1110,1111,1112,1200,1210,1212,1300,1310,1311$ $1313,1330,1500,1510,1520,1523,2000,2100,2130,2150,2151$

$20121000,1100,1110,1112,1114,1117,1120,1121,1200,1210,1211$ $1213,1220,1221,1500,1510,1520,1522,1523,1540$

$20031000,1100,1110,1111,1112,1118,1120,1121,1127,1400,1410$ $1500,1510,1520,1521,1550$ 
Livingston, R. J. (1991). Historical Relationships between Research and ResourceManagement in the Apalachicola River Estuary. Ecological Applications, 1(4), 361382.

Luks, F., \& Siebenhuner, B. (2007). Transdisciplinarity for social learning? The contribution of the German socio-ecological research initiative to sustainability governance. Ecological Economics, 63(2-3), 418-426.

Mace, G. M., \& Purvis, A. (2008). Evolutionary biology and practical conservation: bridging a widening gap. Molecular Ecology, 17(1), 9-19.

Macleod, C. J. A., Blackstock, K. L., \& Haygarth, P. M. (2008). Mechanisms to Improve Integrative Research at the Science-Policy Interface for Sustainable Catchment Management. Ecology and Society, 13(2).

Manolis, J. C., Chan, K. M., Finkelstein, M. E., Stephens, S., Nelson, C. R., Grant, J. B., \& Dombeck, M. P. (2009). Leadership: a New Frontier in Conservation Science. Conservation Biology, 23(4), 879-886.

Maris, V., \& Bechet, A. (2010). From Adaptive Management to Adjustive Management: A Pragmatic Account of Biodiversity Values. Conservation Biology, 24(4), 966-973.

Marzluff, J. M., Raphael, M. G., \& Sallabanks, R. (2000). Understanding the effects of forest management on avian species. Wildlife Society Bulletin, 28(4), 1132-1143.

McCleery, R. A., Lopez, R. R., \& Silvy, N. J. (2007). Transferring research to endangered species management. Journal of Wildlife Management, 71(7), 2134-2141.

Meinard, Y., \& Quetier, F. (2014). Experiencing Biodiversity as a Bridge over the Science-Society Communication Gap. Conservation Biology, 28(3), 705-712.

Messmer, T. A., Reiter, D., \& West, B. C. (2001). Enhancing wildlife sciences' linkage to public policy: lessons from the predator-control pendulum. Wildlife Society Bulletin, 29(4), 1253-1259.

$\mathrm{N}$

$19911000,1200,1210,1212,1300,1320,1330$

$\mathrm{N}$

2007 1000, 1300, 1330, 2000, 2100, 2120, 2140, 2141, 2150, 2151, 2153,

$1000,1100,1110,1111,1112,1117,1120,1127,1129.5,1130$,

$20081131,1300,1310,1311,1312,1500,1510,1520,1521,2000,2100$, 2110

$1000,1100,1110,1114,1120,1121,1125,1126,1127,1130,1131$, $20081200,1230,1300,1310,1311,1400,1420,2000,2100,2120,2130$, 2160

$20091000,1100,1110,1111,1112,1223,1500,1510,1520,1521,1522$, $1530,1532,1540,1550$

$20101000,1100,1110,1116,1120,1125,1127,1550$

$20001000,1100,1110,1113,1119,1130,1131,1400,1420,1500,1520$ 1523

$20071000,1200,1210,1212,1220,1221,1222,1300,1310,1311,1312$ $1500,1530,1532$

$20141000,1100,1120,1126,1200,1210,1212$

$20011000,1100,1120,1125,1127,1130,1131,1200,1210,1211,1213$ $1300,1310,1311,1312,1330,1500,1510,1520,1522$ 
Müller, J., \& Opgenoorth, L. (2014). On the gap between science and conservation implementation-A national park perspective. Basic and Applied Ecology, 15(5), 373378.

Murphy, S. C., \& Kaeding, B. (1998). Fishing bridge: 25 years of controversy regarding grizzly bear management in Yellowstone National Park. In Ursus, Vol 10 - 1998 (Vol. 10, pp. 385-393). West Glacier: International Association on Bear Research \& Management.

Nassauer, J. I., \& Opdam, P. (2008). Design in science: extending the landscape ecology paradigm. Landscape Ecology, 23(6), 633-644.

Norse, D., \& Tschirley, J. B. (2000). Links between science and policy making. Agriculture Ecosystems \& Environment, 82(1-3), 15-26.

Norton, B. G. (1998). Improving ecological communication: The role of ecologists in environmental policy formation. Ecological Applications, 8(2), 350-364.

Ormerod, S. J., Barlow, N. D., Marshall, E. J. P., \& Kerby, G. (2002). The uptake of applied ecology. Journal of Applied Ecology, 39(1), 1-7.

Osmond, D. L., Nadkarni, N. M., Driscoll, C. T., Andrews, E., Gold, A. J., Allred, S. R. B., Berkowitz, A. R., Klemens, M. W., ... Groffman, P. M. (2010). The role of interface organizations in science communication and understanding. Frontiers in Ecology and the Environment, 8(6), 306-313.

Palmer, M. A., Bernhardt, E. S., Chornesky, E. A., Collins, S. L., Dobson, A. P., Duke, C. S., Gold, B. D., Jacobson, R. B., ... Turner, M. G. (2005). Ecological science and sustainability for the 21st century. Frontiers in Ecology and the Environment, 3(1), 411.

Patten, D. (1993). Integrating Science and Decision-Making Riparian Management: Common Threads and Shared Interests: A Western Regional Conference on River Management Strategies, 226, 167-172.

$1000,1100,1110,1112,1117,1120,1129,1200,1220,1221,1300$ $1330,1500,1520,1521$

$1000,1100,1110,1111,1119,1120,1121,1124,1126,1129$,

$1000,1100,1110,1111,1112,1113,1200,1210,1211,1500,1520$ 1521

$19931000,1200,1220,1222,1300,1310,1311,1330$ 
Peuhkuri, T. (2002). Knowledge and interpretation in environmental conflict Fish farming and eutrophication in the Archipelago Sea, SW Finland. Landscape and Urban Planning, 61(2-4), 157-168.

Pierce, S. M., Cowling, R. M., Knight, A. T., Lombard, A. T., Rouget, M., \& Wolf, T. (2005). Systematic conservation planning products for land-use planning: Interpretation for implementation. Biological Conservation, 125(4), 441-458.

Pietri, D. M., Gurney, G. G., Benitez-Vina, N., Kuklok, A., Maxwell, S. M., Whiting, L., Vina, M. A., \& Jenkins, L. D. (2013). Practical Recommendations to Help Students Bridge the Research-Implementation Gap and Promote Conservation. Conservation Biology, 27(5), 958-967.

Poff, N. L., Allan, J. D., Palmer, M. A., Hart, D. D., Richter, B. D., Arthington, A. H., Rogers, K. H., Meyers, J. L., \& Stanford, J. A. (2003). River flows and water wars: emerging science for environmental decision making. Frontiers in Ecology and the Environment, 1(6), 298-306.

Pouyat, R. V., Weathers, K. C., Hauber, R., Lovett, G. M., Bartuska, A., Christenson, L., Davis, J. L. D., Findlay, S. E. G., ... Lymn, N. (2010). The role of federal agencies in the application of scientific knowledge. Frontiers in Ecology and the Environment, $8(6), 322-328$.

Prendergast, J. R., Quinn, R. M., \& Lawton, J. H. (1999). The gaps between theory and practice in selecting nature reserves. Conservation Biology, 13(3), 484-492.

Pullin, A. S., Knight, T. M., \& Watkinson, A. R. (2009). Linking reductionist science and holistic policy using systematic reviews: unpacking environmental policy questions to construct an evidence-based framework. Journal of Applied Ecology, 46(5), 970-975.

Reyers, B., Roux, D. J., \& O’Farrell, P. J. (2010). Can ecosystem services lead ecology on a transdisciplinary pathway? Environmental Conservation, 37(4), 501-511.

Reyers, Belinda, Roux, D. J., Cowling, R. M., Ginsburg, A. E., Nel, J. L., \& O’ Farrell, P. (2010). Conservation planning as a transdisciplinary process. Conservation Biology, 24(4), 957-65.
$1000,1100,1110,1111,1113,1120,1125,1127,1130,1131,1300$ $1320,1330,2000,2100,2120,2130,2150,2153$

$1000,1100,1110,1112,1113,1115,1116,1200,1210,1212,1220$, $1222,1300,1310,1311,1312,1524,2145$

$1000,1100,1110,1113,1300,1330,1500,1510,1520,1521,1522$, $1523,2000,2100,2110$

$1000,1100,1110,1111,1113,1114,1118,1119,1120,1124,1125$, $20031126,1133,1200,1210,1212,1300,1330,1500,1520,1523,1530$ $1532,1540,2000,2100,2130$

$1000,1100,1110,1112,1117,1200,1210,1212,1300,1310,1311$ $1312,1340,1500,1510,1520,1521,1523$

$1000,1100,1110,1113,1120,1121,1122,1129,1200,1210,1211$, $19991220,1221,1222,1300,1310,1311,1312,1500,1510,1520,1523$ $2000,2100,2110$

$20101000,1100,1110,1111,1113,2000,2100,2110,2120,2130,2140$ $2142,2145,2150,2151$
$20101000,1100,1110,1111,1300,1310,1311,2000,2100,2110,2120$ $2130,2140,2141,2142,2143,2150,2151,2160$ 
Roux, D. J., Rogers, K. H., Biggs, H. C., Ashton, P. J., \& Sergeant, A. (2006). Bridging the science-management divide: Moving from unidirectional knowledge transfer to knowledge interfacing and sharing. Ecology and Society, 11(1).

Rudd, M. A. (2011). How Research-Prioritization Exercises Affect Conservation Policy. Conservation Biology, 25(5), 860-866.

Seavy, N. E., \& Howell, C. A. (2010). How can we improve information delivery to support conservation and restoration decisions? Biodiversity and Conservation, 19(5), 1261-1267.

Seely, M., Klintenberg, P., \& Kruger, A. S. (2008). The Unmet Challenge of Connecting Scientific Research with Community Action. In Future of Drylands (pp. 687-697). Dordrecht: Springer.

Shackleton, C. M., Cundill, G., \& Knight, A. T. (2009). Beyond Just Research: Experiences from Southern Africa in Developing Social Learning Partnerships for Resource Conservation Initiatives. Biotropica, 41(5), 563-570.

Shanley, P., \& López, C. (2009). Out of the loop: why research rarely reaches policy makers and the public and what can be done. Biotropica, 41(5), 535-544.

Shaw, J. D., Wilson, J. R. U., \& Richardson, D. M. (2010). Initiating dialogue between scientists and managers of biological invasions. Biological Invasions, 12(12), 40774083 .

Simonetti, J. A. (2011). Conservation biology in Chile: Are we fulfilling our social contract? Revista Chilena De Historia Natural, 84(2), 161-170.

Singh, G. G., Tam, J., Sisk, T. D., Klain, S. C., Mach, M. E., Martone, R. G., \& Chan, K. M. A. (2014). A more social science: barriers and incentives for scientists engaging in policy. Frontiers in Ecology and the Environment, 12(3), 161-166.

Sitas, N., Prozesky, H. E., Esler, K. J., \& Reyers, B. (2014). Opportunities and challenges for mainstreaming ecosystem services in development planning: perspectives from a landscape level. Landscape Ecology, 29(8), 1315-1331.
$20061222,1300,1310,1311,1500,1510,1530,1532,2000,2100,2110$, 2120, 2130, 2140, 2141, 2142, 2150, 2151, 2153

$20111000,1100,1110,1112,1119,1120,1125,1130,1131,1200,1220$ $1222,1300,1310,1311,1320,1330,1500,1540,1550$

$20101000,1200,1210,1212,1230$

$\mathrm{P}$

2008

$1000,1200,1210,1212,1213,1230,1500,1510,1520,1521,2000$, 2100,2130

$1000,1100,1110,1112,1116,1117,1119,1200,1210,1211,1300$,

$20091310,1312,1500,1520,1522,1523,2000,2100,2110,2120,2130$ $2140,2141,2142,2143,2144,2150,2151,2153,3000$

$\mathrm{P}$

$20091000,1100,1110,1112,1200,1210,1211,1500,1520,1521,1522$ $1523,2000,2100,2140,2141,2150,2151$

$1000,1100,1120,1121,1122,1127,1130,1132,1200,1210,1212$, $1220,1221,1222,1500,1510$

$1000,1100,1110,1112,1120,1121,1130,1132,1200,1220,1221$ $1313,1500,1520,1523,2000,2100,2140,2141$

$20141000,1500,1510,1530,1532$

$1000,1100,1110,1113,1120,1121,1126,1127,1130,1132,1200$, $1220,1221,1222,1300,1310,1311,1312,2000,2100,2110$ 
Soberon, J. M., \& Sarukhan, J. K. (2009). A new mechanism for science-policy transfer and biodiversity governance? Environmental Conservation, 36(04), 265-267.

Stevens, C. J., Fraser, I., Mitchley, J., \& Thomas, M. B. (2007). Making ecological science policy-relevant: issues of scale and disciplinary integration. Landscape Ecology, 22(6), 799-809.

Stromberg, J. C., Chew, M. K., Nagler, P. L., \& Glenn, E. P. (2009). Changing Perceptions of Change: The Role of Scientists in Tamarix and River Management. Restoration Ecology, 17(2), 177-186.

Sunderland, T., Sunderland-Groves, J., Shanley, P., \& Campbell, B. (2009). Bridging the Gap: How Can Information Access and Exchange Between Conservation Biologists and Field Practitioners be Improved for Better Conservation Outcomes? Biotropica, 41(5), 549-554.

Sutherland, W. J., Fleishman, E., Mascia, M. B., Pretty, J., \& Rudd, M. A. (2011). Methods for collaboratively identifying research priorities and emerging issues in science and policy. Methods in Ecology and Evolution, 2(3), 238-247.

Szaro, R. C., Berc, J., Cameron, S., Cordle, S., Crosby, M., Martin, L., Norton, D., O'Malley, R., \& Ruark, G. (1998). The ecosystem approach: science and information management issues, gaps and needs. Landscape and Urban Planning, 40(1-3), 89-101.

Termorshuizen, J. W., \& Opdam, P. (2009). Landscape services as a bridge between landscape ecology and sustainable development. Landscape Ecology, 24(8), 10371052 .

Theobald, D. M., Spies, T., Kline, J., Maxwell, B., Hobbs, N. T., \& Dale, V. H. (2005). Ecological support for rural land-use planning. Ecological Applications, 15(6), 19061914.

Underwood, A. J. (1995). Ecological Research and (and Research into) EnvironmentalManagement. Ecological Applications, 5(1), 232-247.

Underwood, A. J. (1998). Relationships between ecological research and environmental management. Landscape and Urban Planning, 40(1-3), 123-130.

$20091000,1100,1110,1113,1120,1124,1240$

$\mathrm{P}$

$20071000,1100,1110,1111,1113,1118,1200,1210,1212,1500,1520$, $1521,1523,2000,2100,2145,2150,2151$

$20091000,1100,1120,1128,1140,1200,1210,1212,1220,1222$

2009

$1000,1100,1110,1111,1120,1121,1123,1129,1200,1220,1221$, $1222,1400,1410,1500,1510,1520,1521,1522,1523,2160$

$20111000,1100,1120,1121,1200,1210,1211,1300,1310,1312,1400$, 1420

$1000,1100,1110,1111,1112,1113,1114,1119,1120,1125,1127$, $19981130,1131,1133,1200,1210,1212,1220,1221,1300,1330,1500$ $1510,1520,1521,1524,1540,2000,2100,2140,2143$

$20091000,1100,1110,1111,1113,2000,2100,2110,2120,2130$

$20051000,1100,1110,1113,1120,1122,1129.5,1130,1131,1200$ $1210,1211,1300,1310,1312,2000,2100,2150,2151$

$1000,1100,1110,1112,1113,1118,1119,1120,1121,1125,1130$ $19951131,1200,1210,1212,1220,1222,1300,1320,1400,1410,1500$, 1510

$19981000,1100,1110,1112,1118,1120,1121,1125,1129.5,1200$ $1210,1211,1212,1220,1222,1500,1510,1550$ 
Van der Windt, H. J., \& Swart, J. A. A. (2008). Ecological corridors, connecting science and politics: the case of the Green River in the Netherlands. Journal of Applied Ecology, 45(1), 124-132.

van Latesteijn, H. C. (1998). A policy perspective on land use changes and risk assessment. Agriculture Ecosystems \& Environment, 67(2-3), 289-297.

Vimal, R., Mathevet, R., \& Thompson, J. D. (2012). The changing landscape of ecological networks. Journal for Nature Conservation, 20(1), 49-55.

Walters, C. J. (1998). Improving links between ecosystem scientists and managers. In Successes, Limitations, and Frontiers in Ecosystem Science (pp. 272-286). New York: Springer.

Weinstein, M. P., Litvin, S. Y., \& Krebs, J. M. (2014). Restoration ecology: Ecological fidelity, restoration metrics, and a systems perspective. Ecological Engineering, 65, 7187.

Winter, M., Devictor, V., \& Schweiger, O. (2013). Phylogenetic diversity and nature conservation: where are we? Trends in Ecology \& Evolution, 28(4), 199-204.

Young, K. D., \& Van Aarde, R. J. (2011). Science and elephant management decisions in South Africa. Biological Conservation, 144(2), 876-885.

Zavaleta, E., Miller, D. C., Salafsky, N., Fleishman, E., Webster, M., Gold, B., Hulse, D., Rowen, M., ... Vanderryn, J. (2008). Enhancing the Engagement of the U.S. Private Foundations with Conservation Science. Conservation Biology, 22(6), 1477-1484.
$1000,1100,1110,1117,1120,1122,1125,1126,1127,1130,1131$ $1140,1300,1330,2000,2100,2120$

$19981000,1100,1110,1116,1120,1125,1300,1310,1311,1320,1340$ 1500,1510

$20121000,1200,1210,1212,1500,1530,1531,2000,2100,2130$

$1000,1100,1110,1112,1113,1118,1120,1129,1130,1132,1200$,

$19981210,1212,1300,1310,1312,1340,1500,1510,1520,1521,2000$, $2100,2130,2140,2141,2150,2152$

$20141000,1100,1130,1131,1300,1330$

$20131000,1100,1110,1112,1120,1125,1127,1130,1131,1132$

$1000,1100,1110,1112,1113,1117,1120,1121,1127,1128,1129$,

$20111130,1131,1132,1300,1310,1312,1320,1500,1510,1520,1521$, 1524

$20081000,1100,1120,1121,1200,1220,1221,1222,1300,1330$ 


\section{Appendix S4 - Additional information on the sorting activities}

Groups of scientists for the sorting activity

The first group was composed by the first author of this study and two scientists from the Conservation Science Group (University of Cambridge, UK). The second group was composed by the first author, one person from the first group and two other scientists from the Conservation Science Group (University of Cambridge, UK). The

activities of these two groups were conducted in April 2015. The third group was composed by all authors of this study and was conducted in July 2015.

Classification of perceived causes obtained in the sorting activities

See Table S2 in the next page. 
Table S2. Distinct types of classification of perceived causes of the science-practice gap in Ecology and Conservation obtained in the sorting activities (see main text for explanation). Advantages and disadvantages of each classification are those discussed in the group meetings. The criteria are numbered as in the main text. The "number of people" refers to the number of people that proposed each type of classification and in parenthesis are the groups they belonged to. G1 = first group; G2 = second group; G3 = third group.

\begin{tabular}{|c|c|c|c|c|c|}
\hline $\begin{array}{c}\text { Classification } \\
\text { type }\end{array}$ & Explanation & Advantages & Disadvantages & $\begin{array}{c}\text { Fulfilled } \\
\text { criteria }\end{array}$ & $\begin{array}{c}\text { Number of } \\
\text { people }\end{array}$ \\
\hline $\begin{array}{l}\text { Based on } \\
\text { components }\end{array}$ & $\begin{array}{l}\text { The categories of perceived causes are based on } \\
\text { the characteristics of the components involved } \\
\text { in the science-practice interface. E.g.: scientists, } \\
\text { universities, decision-makers and organizations } \\
\text { involved in practice. }\end{array}$ & $\begin{array}{l}\text { - Logical structure } \\
\text { - Easily comprehensible } \\
\text { - Mutually exclusive } \\
\text { categories }\end{array}$ & $\begin{array}{l}\text { - Simplified presentation of the } \\
\text { problem of the science-practice gap } \\
\text { - Perceived causes within } \\
\text { perspectives assuming one or two } \\
\text { knowledges are not distinguishable }\end{array}$ & 1,2 & $\begin{array}{l}2 \\
(\mathrm{G} 1, \mathrm{G} 2 \\
\mathrm{G} 3)\end{array}$ \\
\hline $\begin{array}{l}\text { Based on } \\
\text { processes }\end{array}$ & $\begin{array}{l}\text { The categories of perceived causes are based on } \\
\text { the processes involved in the science-practice } \\
\text { interface. E.g.: knowledge generation, } \\
\text { knowledge communication and knowledge use. }\end{array}$ & $\begin{array}{l}\text { - Logical structure } \\
\text { - Easily comprehensible } \\
\text { - Mutually exclusive } \\
\text { categories } \\
\text { - Presentation more coherent } \\
\text { with the complexity of the } \\
\text { problems of the science- } \\
\text { practice gap }\end{array}$ & $\begin{array}{l}\text { - Perceived causes related to personal } \\
\text { and cultural characteristics of the } \\
\text { actors are not represented }\end{array}$ & $1,2,3$ & $\begin{array}{c}2 \\
(\mathrm{G} 3)\end{array}$ \\
\hline $\begin{array}{l}\text { Based on } \\
\text { personal opinion } \\
\text { and previous } \\
\text { experiences }\end{array}$ & $\begin{array}{l}\text { The categories of perceived causes are divided } \\
\text { into general important issues based on the } \\
\text { opinion and previous experiences of the sorters. } \\
\text { E.g.: personal belief and attitudes, disciplinary } \\
\text { problems, interpretation problems and logistic } \\
\text { issues. }\end{array}$ & $\begin{array}{l}\text { - Presentation more coherent } \\
\text { with the complexity of the } \\
\text { problem of the science- } \\
\text { practice gap }\end{array}$ & $\begin{array}{l}\text { - No clear logical structure } \\
\text { - Not easily comprehensible by others } \\
\text { - Categories not necessarily mutually } \\
\text { exclusive } \\
\text { - Perceived causes within } \\
\text { perspectives assuming one or two } \\
\text { knowledges are not distinguishable }\end{array}$ & --- & $\begin{array}{c}2 \\
(\mathrm{G} 2)\end{array}$ \\
\hline
\end{tabular}




\begin{tabular}{|c|c|c|c|c|c|}
\hline $\begin{array}{c}\text { Classification } \\
\text { type }\end{array}$ & Explanation & Advantages & Disadvantages & $\begin{array}{c}\text { Fulfilled } \\
\text { criteria }\end{array}$ & $\begin{array}{c}\text { Number of } \\
\text { people }\end{array}$ \\
\hline $\begin{array}{l}\text { No explicit } \\
\text { organization base }\end{array}$ & $\begin{array}{l}\text { The categories of perceived causes do not refer } \\
\text { to any entity specifically, but are organized in } \\
\text { an entirely inductive way from the sentences. }\end{array}$ & --- & $\begin{array}{l}\text { - No logical structure } \\
\text { - Not easily comprehensible by others } \\
\text { - Perceived causes within } \\
\text { perspectives assuming one or two } \\
\text { knowledges are not distinguishable } \\
\text { - Perceived causes related to personal } \\
\text { characteristics are not represented } \\
\text { - Categories not necessarily mutually } \\
\text { exclusive }\end{array}$ & --- & $\begin{array}{c}2 \\
(\mathrm{G} 1, \mathrm{G} 3)\end{array}$ \\
\hline
\end{tabular}




\section{Appendix S5 - Additional information on the conceptual framework reliability.}

\section{Detailed methods}

We estimated the conceptual framework reliability through the pairwise agreement between one author (DBG) and two outside evaluators in the allocation of sentences into the framework categories. Each evaluator allocated a different set of 150 sentences (approximately 10\% of all 1563 sentences) into the categories. One of the sets included the three most explicit and precise sentences, while the other included three random sentences, for each of the 48 categories. This procedure guaranteed all categories were represented among the sentences used for calculating reliability (Krippendorff, 2004a). The remaining six sentences required to complete 150 sentences in each set were randomly sampled from all categories. Both evaluators had not participated in other stage of the study, had a Bachelor's degree in Biology, were PhD students in Ecology, had experience in areas where ecological knowledge is applied, and received the same instructions.

The written instructions given to the two outside evaluators consisted of: (1) a brief overview of the underlying logic of the framework and an explanation of the procedures for them to allocate each sentence into the categories; (2) a table similar to Table 1 to facilitate the visualization of all categories and their hierarchy within the conceptual framework; and (3) the detailed criteria and examples of sentences of all categories, similar to Appendix S6.

The two outside evaluators received the document one week before a meeting, when the first author conducted an oral presentation about the underlying logic of the framework and the procedures to allocate each sentence into the categories, and when doubts were resolved. They then received the list of 150 sentences to allocate individually into the categories in the following days.

Interrater agreement was estimated separately for each author-evaluator pair using the general equation for interrater agreement coefficients (Krippendorff, 2004b)

$$
A g=1-\frac{D_{o}}{D_{e}}
$$


where $\mathrm{Ag}=$ interrater agreement corrected by the agreement expected by chance; $\mathrm{D}_{0}=$ observed disagreement calculated by the percentage of sentences that the two raters allocated to different categories; and $\mathrm{D}_{\mathrm{e}}=$ percentage disagreement expected by chance. The disagreement expected by chance was calculated using the mean percentage disagreement of 1000 simulations, where simulated outside evaluators could allocate each sentence to any category with equal probability. Using this formula, the interrater agreement is 0 when equal to the expected by chance and 1 when there is perfect agreement. We calculated the agreement for every level in the conceptual framework and considered that a coefficient greater than 0.67 indicates adequate agreement (Krippendorff, 2004b). All calculations were computed in the $\mathrm{R}$ environment ( $\mathrm{R}$ Development Core Team, 2008).

\section{Results}

The reliability was adequate for the first three hierarchical levels and moderately lower for the fourth hierarchical level, as expected, given the similarity among categories in this case is greater than among categories within higher hierarchical levels (Table S3).

Table S3. Estimated interrater agreement coefficients for two author-evaluator pairs in the allocation of a set of 150 sentences (either the most explicit and precise sentences or random sentences) into the framework categories.

\begin{tabular}{ccc}
\hline Hierarchical level & $\begin{array}{c}\text { Explicit and precise } \\
\text { sentences }\end{array}$ & $\begin{array}{c}\text { Random } \\
\text { sentences }\end{array}$ \\
\hline First & 0.88 & 0.83 \\
Second & 0.75 & 0.68 \\
Third & 0.74 & 0.68 \\
Fourth & 0.63 & 0.52 \\
\hline
\end{tabular}

\section{References}

KRIPPENDORFF, K. (2004a) Content analysis: an introduction to its methodology, 2nd edition. Sage Publications, California.

KRIPPENDORFF, K. (2004b) Reliability in content analysis: Some common misconceptions and recommendations. Human Communication Research 30, 411-433.

R Development CoRe TEAm (2008) R: A Language and Environment for Statistical Computing. R Foundation for Statistical Computing, Vienna, Austria. 


\section{Appendix S6 - Complete version of the conceptual framework of perceived causes of the science-practice gap in Ecology and Conservation.}

Table S4. Complete version of the conceptual framework of perceived causes of the science-practice gap in Ecology and Conservation, with detailed description of criteria defining each category and number of sentences found in the literature for each category $(\mathrm{N})$. The formatting of titles indicates the category hierarchical level (FIRST, Second, Third, Fourth). Due to space restrictions, we describe only the criteria of lower-level categories that add in terms of content from the criteria of higher-level categories. We included examples of sentences only for the lower-level categories since every sentence allocated to one lower-level category represents also its higher-order categories. We omitted in-text citations in the examples to save space, though the page where the sentence appears in the article is presented to facilitate finding these sentences and its in-texts citations in the original text. Lastly, the "context" of sentences referred to in the criteria represents three to four lines before and/or after the sentence and are presented in gray in the examples.

\begin{tabular}{lll}
\hline Code Category & Inclusion criterion & Example of included sentence (when applicable) \\
\hline
\end{tabular}

\section{ONE KNOWLEDGE}

\section{Problems in knowledge generation}

1110

Flawed or inefficient
Sentences, together with its context, indicate a perspective on the linkage between science and practice in which only scientific knowledge is considered important to support decision-making and practical actions, therefore establishing a unidirectional flow of knowledge from science to practice, with possible feedback of research needs and practical results from practice to science. From this perspective, the causes of the science-practice gap are associated with problems perceived to affect one or all of four processes linking science and practice (i.e., knowledge generation, communication, use and feedback), which are deemed to hinder or prevent decision-making and practical actions from being based on scientific knowledge. ${ }^{1}$

Sentences indicate the causes of the science-practice gap are associated with flaws, errors and/or inefficiencies in the generation of scientific knowledge, including the definition of research questions and methodology, the conducting of research, the research results and the proposed practical implications and recommendations derived from these results. Sentences, together with its context, indicate these flaws, errors and/or inefficiencies are deemed to hinder or prevent decision-making and practical actions from being based on scientific knowledge. research
Sentences indicate the causes of the science-practice gap lie on flaws, errors and/or inefficiencies in scientific research. Sentences, together with its context, indicate these flaws, errors and/or inefficiencies are deemed to render scientific research incompatible with generation of useful knowledge for practice.

1 Despite the fact that the underlying logic of the conceptual framework would allow a category related to a perspective considering only practical knowledge is important to support decisionmaking and practical actions, we did not find this perspective in the reviewed articles. Some articles described the need of decision-makers to base their decisions and actions on practical knowledge, but only because it was impossible to use scientific knowledge for several reasons. 
$1111 \quad$ Fragmentation

$1112 \quad$ Inadequate questions

$1113 \quad$ Inadequate scale
Sentences indicate the causes of the science-practice gap lie on the segregation of scientific disciplines or even of subareas in one discipline, such that the generation of scientific knowledge is fragmented, disciplinary and conducted without communication between different areas.

Sentences indicate the causes of the science-practice gap lie on the fact research questions and objectives and/or their formulation are inadequate or not aligned with (i.e., do not answer to) the knowledge needs of decision-makers.

Sentences indicate the causes of the science-practice gap lie on the fact scientific research is conducted in spatial and/or temporal scales inadequate to the practical questions faced by decision-makers.

Sentences indicate the causes of the science-practice gap lie on the fact the scientific approach is reductionist, focusing on the investigation of isolated factors, without considering the environmental complexity and/or the joint action of several factors in practical problems.

Sentences indicate the causes of the science-practice gap lie on the fact scientific approaches focus mostly on technical development of methodological procedures, e.g., spatial prioritization techniques.
"Translating scientific findings into conservation action remains difficult due to communication gaps across scientific disciplines, and gaps between scientists and other stakeholders such as Government (decision makers and implementers), NGOs (conservationists and environmental advocates) and local communities." (Githiru et al., 2011, p. 263)

“(...) there is a research-implementation gap in ecological restoration. Many reasons are offered to explain this gap. Research that scientists believe might inform practice may not address the questions most relevant to practitioners. Practitioners may not recognize or understand the work of researchers or may dislike prescriptive approaches (...)" (Lauber et al., 2011, p. 1187)

“(...) we ask why so much ecological scientific research does not have a greater policy impact in the UK. We argue that there are two potentially important and related reasons for this failing.

First, much current ecological science is not being conducted at a scale that is readily meaningful to policy-makers. Second, (...)" (Stevens et al., 2007, p. 799)

“(...) a tendency to simplify research questions to suit rigorous scientific methods can compromise the salience of those questions for decision makers, who must confront the real complexity of environmental problems. Conversely, credible research can lead to highly technical outputs that practitioners find unintelligible (...)" (Cook et al., 2013, p. 671)

"Most [conservation assessment models] are focused on assessment of biological entities, reflecting a fascination with the refinement of systematic assessment techniques. (...). These guide the science of selecting areas for conservation, but reveal little of how to operationalize systematic assessments in conservation planning processes." (Knight et al., 2006, p. 413) 
$1116 \quad$ Isolation from practice

Long time period for scientific knowledge generation

Characteristics of knowledge or of implications
Sentences indicate the causes of the science-practice gap lie on the fact scientific research as a whole is conducted isolated or disconnected from practice, without participation of decision-makers and/or ignoring their perspectives and/or values. ${ }^{2}$

Sentences indicate the causes of the science-practice gap lie on the fact the generation of scientific knowledge is slow, with long time periods elapsed between research beginning and results being available for practice (e.g., in publications), where prompt decisions and actions need to be made.

Sentences indicate the causes of the science-practice gap lie on the fact not every research useful for practice can be conducted, because of issues of scale, time and limited resources.
"Barriers to acceptance of new technologies may be also institutional and cultural. First (...). Second, even research that is meant to inform resource-management decisions may not include managers in defining the problem or discussing the acceptability or feasibility of a proposed solution. Third, (...)" (Hall \& Fleishman, 2010, p. 122)

“(...) managers suggested that a lack of site-specific scientific studies, the length of time between studies beginning and findings of relevance being available to managers, and the limited practicality of science recommendations meant that they were forced to rely on non scientific studies." (Young \& Van Aarde, 2011, p. 883)

"Scientists have not, and probably never will, study many of the difficult processes that are key to management prediction but are too expensive or time-consuming for attack by traditional scientific methods of investigation." (Walters, 1998, p. 275)

Sentences indicate the causes of the science-practice gap lie on flaws, errors and/or inefficiencies in scientific research that are deemed to render it incompatible with generation of useful knowledge for practice, but the appointed cause does not fit in any of the lower-level categories of "Flawed or inefficient research" mentioned above.

Sentences indicate the causes of the science-practice gap lie on characteristics of the existent body of scientific knowledge or of proposed practical implications and recommendations derived from it that are deemed to make scientific knowledge useless, inappropriate and/or irrelevant for practice. ${ }^{3}$

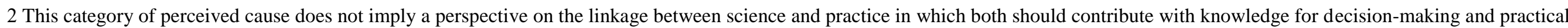

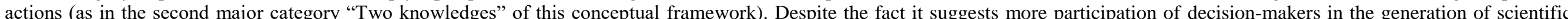

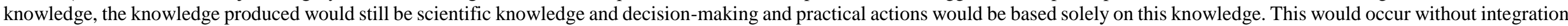
between different knowledge sources. See Tress et al. (2005) for a detailed explanation on the difference between participation and integration.

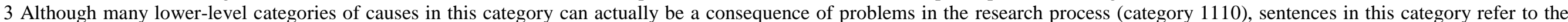
products of the research process, and not to the research process itself. 
$1121 \quad$ Irrelevant

1122 Disciplinary

Abstract/theoretical
Sentences indicate the causes of the science-practice gap lie on the fact scientific knowledge is irrelevant, inappropriate and/or useless for practice, but without explaining why it is irrelevant, inappropriate or useless.
Sentences indicate the causes of the science-practice gap lie on the fact scientific knowledge is disciplinary.
"To attract funding and facilitate publication in reputable journals, research questions must be novel, but if the research is not relevant to the current problems faced by decision makers it will not influence conservation practice." (Cook et al., 2013, p. 671)

"Existing operational models provide an important foundation for conservation planning; most, however, oversimplify the reality of real-world initiatives. Typically they focus on biological entities and not the broader social-ecological systems in which conservation planning initiatives operate. Most are linear operational models and so can only provide partial conservation solutions (...)", (Knight et al., 2006, p. 410)

Sentences indicate the causes of the science-practice gap lie on the fact the existent body of scientific knowledge consists mainly of abstract, theoretical and/or conceptual constructions (i.e., group of general prepositions that explain phenomena in different situations) and, therefore, is barely applicable.

Sentences indicate the causes of the science-practice gap lie on the fact scientific knowledge generated by single studies is not generalizable or has limited Limited generalizability generalizability, hindering extrapolation of results from one place to another and rendering scientific knowledge useless for the situations related to practical problems. $^{4}$
"More generally conservation biology has a poor record of translating research into action because most research has been theoretical. Whitten et al. (2001) laments our impotence as a discipline to stem habitat destruction and species extinction in priority areas." (Knight et al., 2008, p. 612)

"Nevertheless, fundamental problems of uncertain knowledge and limited predictive capability continue to beset the science both from irreducible ecosystem complexity, and from the limited transferability of general ecological understanding to sitespecific situations. " (Poff et al., 2003, p. 300) underlying river ecosystem management. This uncertainty arises

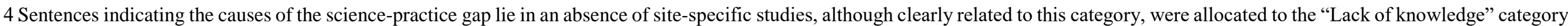
(code 1131), as they point out the cause as an absence of scientific products and not as a characteristic of scientific knowledge itself. 
$1125 \quad$ Uncertain

$1126 \quad$ Complicated

$1127 \quad$ Controversial

$1128 \quad$ Unreliable
Sentences indicate the causes of the science-practice gap lie on the fact there are uncertainties associated with scientific knowledge. ${ }^{5}$

Sentences indicate the causes of the science-practice gap lie on the fact the existent body of scientific knowledge is complicated.

Sentences indicate the causes of the science-practice gap lie on the fact scientific knowledge is controversial, with often contradictory results that can change over time and lack of consensus regarding practical implications and recommendations.

Sentences indicate the causes of the science-practice gap lie on the fact scientific knowledge generated by particular studies is unreliable and/or of poor quality, being generated without scientific rigor.

Sentences indicate the causes of the science-practice gap lie on the fact the practical implications of scientific knowledge proposed by scientists (i.e., recommendations, tools and/or practical protocols) are
“(...) [research] should be readily available to help define the nature of a problem and to evaluate options for its solution.

Unfortunately, there are probably two major impediments to the useful availability of much ecological research. The first is that ecological information-even in well-studied systems-is patchy in reliability and uncertain in its predictive capacity." (Underwood, 1998, p. 125)

"(...) the respondents identified the complexity of academic content in scientific publications as an additional cause for knowing-doing gaps. " (Habel et al., 2013, p. 2414)

“(...) there are many areas of conservation science where there is no consensus among researchers as to what might be the best recommendation to practitioners. (...). Diverse viewpoints are essential for the development of a self-critical ecological science, but such mixed messages are difficult to translate into action." (Hulme, 2014, p. 1135)

"Limitations identified by 30 elephant managers. (...)

Too many scientific studies are done by young students with no experience in veldt management thus making findings unreliable

Science findings become political making them difficult to incorporate into management decisions (...)" (Young \& Van Aarde, 2011, p. 882)

"In some cases, it may be more appropriate for decision makers not to incorporate science when innovative approaches to solving environmental problems are impractical to implement, too costly, or their outcomes are not sufficiently predictable. The

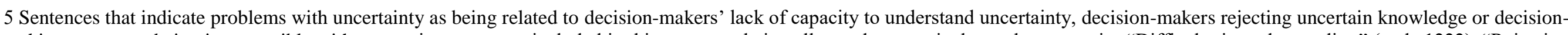

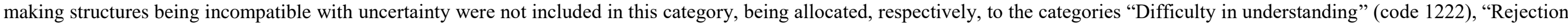
by decision-makers" (code 1311) and "Impediment by the organizational and/or institutional structure" (code 1312). 
inadequate and/or unrealistic, given practical pervasive challenge of developing science that contributes to both restrictions of time, space and resources. scientific understanding and policy decisions has led to several disciplines coining similar terms (...)” (Cook et al., 2013, p. 670)

Other characteristics of knowledge

Knowledge gaps
Lack of knowledge

Other gaps in knowledge

Other problems in knowledge generation
Sentences indicate the causes of the science-practice gap lie on characteristics of the existent body of scientific knowledge or of proposed practical implications and recommendations derived from it that are deemed to make scientific knowledge useless, inappropriate and/or irrelevant for practice, but the appointed cause does not fit in any of the lower-level categories of "Characteristics of knowledge or implications" mentioned above.

Sentences indicate the causes of the science-practice gap lie on gaps in the generation of knowledge, resulting in not enough scientific products (encompassing scientific knowledge and the proposed practical implications and recommendations derived from it) for all questions that are relevant in practice.

Sentences indicate the causes of the science-practice "This study identified several key gaps in the science base needed gap lie on the fact there is not enough scientific for the implementation of ecosystem management including. knowledge for all questions that are relevant in ecology on multiple scales, multiple species science (...)”' (Szaro practice. et al., 1998, p. 89)

“(...) the fraction of Chilean publications offering direct advice Sentences indicate the causes of the science-practice resembles those of the conservation community world-wide. The gap lie on the fact there is not enough practical lack of explicit messages further reduces the chances to implications associated with the existent body of significantly contribute to biodiversity conservation. If messages scientific knowledge for all questions that are relevant in practice, i.e., lack of recommendations, tools and/or practical protocols. are not explicit, it is unlikely that policy makers and managers will invest efforts to reach for information in difficult to access sources, as scientific journals represent for them" (Simonetti, 2011, p. 167)

Sentences indicate the causes of the science-practice gap lie on gaps in the generation of knowledge, resulting in not enough scientific products for all questions in which they are necessary in practice, but the appointed cause does not fit in any of the lower-level categories of "Knowledge gaps" mentioned above.

Sentences indicate the causes of the science-practice gap are associated with flaws, errors and/or inefficiencies in the generation of scientific knowledge that are deemed to hinder or prevent decision-making and practical actions from being 
based on scientific knowledge, but the appointed cause does not fit in any of the third-level categories of "Problems in knowledge generation" mentioned above.

Problems in knowledge communication

Problems in knowledge transfer by scientists

$1211 \quad$ Limited availability

Inadequate translation

Other problems in knowledge transfer
Sentences indicate the causes of the science-practice gap are associated with flaws, errors and/or inefficiencies in the communication of scientific knowledge, including the processes of scientific knowledge transfer and reception. Sentences, together with its context, indicate these flaws, errors and/or inefficiencies are deemed to hinder or prevent decision-making and practical actions from being based on scientific knowledge.

Sentences indicate the causes of the science-practice gap lie on flaws, errors and/or inefficiencies in the transfer of scientific knowledge, namely the processes of scientific knowledge communication for which scientists are responsible (e.g., the scientist translates knowledge, but the decision-maker is the one responsible for accessing knowledge).

Sentences indicate the causes of the science-practice gap lie on the fact scientific knowledge does not leave academia, that is, scientists do not make scientific knowledge available for decision-makers, either because scientific journals are restricted to academia, because scientists do not look for other means of communications and publics or because there is no dissemination or divulgation of scientific results.

Sentences indicate the causes of the science-practice gap lie on the fact scientific knowledge leaves academia in an inadequate manner, either because it is translated to inadequate formats, tools or languages ${ }^{6}$ or because it is translated in a distorted way to decision-makers.

"A few scientists see no reason to communicate with nonscientists and make no effort to do so. They tend to only interact with environmental managers or publish in scientific journals that are not widely read by nonscientists. Agency scientists oftentimes are restricted in their communications on specific environmental issues (...)" (Barbour et al., 2008, p. 566)

"(...) it is also possible that the [ecological] communication problem is significantly due to the language and format in which ecological information is presented to the public; or it may be that most ecologists study aspects and processes of nature that have little interest or application to the public's concerns or to environmental management." (Norton, 1998, p. 352)

Sentences indicate the causes of the science-practice gap lie on flaws, errors and/or inefficiencies in the transfer of scientific knowledge by scientists, but the appointed cause does not fit in any of the lower-level categories of "Problems in knowledge transfer by scientists" mentioned above.

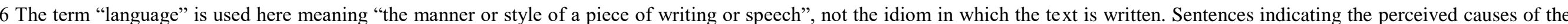
science-practice gap lie on the fact scientific articles are written in English are allocated to the "Lack of Access" category (code 1221). 
Problems in knowledge reception by decisionmakers

Lack of access

Difficulty in understanding

\section{Other problems in} knowledge reception

\section{Problems in}

communication as a whole

Sentences indicate the causes of the science-practice gap lie on flaws, errors and/or inefficiencies in the reception of scientific knowledge, namely the processes of scientific knowledge for which decision-makers are responsible (e.g., the scientist translates knowledge, but the decision-maker is the one responsible for accessing knowledge).

Sentences indicate the causes of the science-practice gap lie on the fact scientific knowledge is not accessed by decision-makers, either because access is difficult for decision-makers or because decision-makers do not concern themselves with accessing scientific knowledge. ${ }^{7}$

Sentences indicate the causes of the science-practice gap lie on the fact scientific knowledge reaches practice, but it is not understood or critically analyzed by decision-makers, it is incorrectly understood or it is difficult to understand. ${ }^{8}$
"Managers sometimes use limited scientific information in their decision-making process, mainly because they have little time to review primary literature before making a decision. Making data readily available to managers is expected to improve the overall efficiency of management interventions." (Drolet et al., 2014, p. 1050)

"There are a number of issues which contribute to the researchimplementation gap,). (...) some practitioners, who are not necessarily all ecologically trained, could have difficulty understanding the research results, particularly where complex statistical analyses and modelling techniques have been used." (Anderson, 2014, p. 1148)

Sentences indicate the causes of the science-practice gap lie on flaws, errors and/or inefficiencies in the reception of scientific knowledge by decision-makers, but the appointed cause does not fit in any of the lower-level categories of "Problems in knowledge reception by decision-makers" mentioned above.

Sentences indicate the causes of the science-practice gap lie on flaws, errors and/or inefficiencies deemed to affect the process of scientific knowledge communication as a whole, including the high costs in terms of time and resources involved in communicating scientific knowledge.
“(...) ecologists and conservation biologists should develop a wide variety of decision support tools and prioritize the one-onone interactions between ecologists and decision makers that will enhance their delivery. Although there is a clear need for oneon-one interactions, this is also one of the costliest modes of information transfer. " (Seavy \& Howell, 2010, p. 1266)

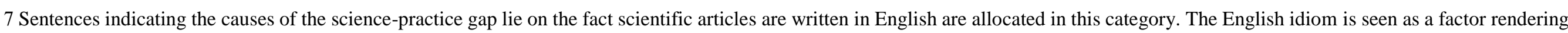

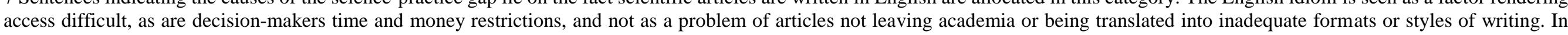
other words, for this view, if decision-makers could read English, there would be no communication problem.

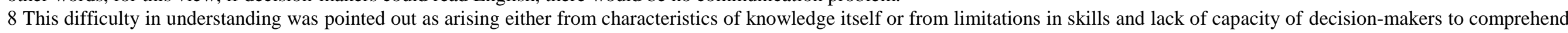
and critically analyze the existent body of scientific knowledge. 
Other problems in knowledge

communication

Problems in knowledge use

Knowledge disregarded

Rejection by decisionmakers

Impediment by the organizational and/or institutional structure
Sentences indicate the causes of the science-practice gap are associated with flaws, errors and/or inefficiencies in the communication of scientific knowledge that are deemed to hinder or prevent decision-making and practical actions from being based on scientific knowledge, but the appointed cause does not fit in any of the third-level categories of "Problems in knowledge communication" mentioned above.

Sentences indicate the causes of the science-practice gap are associated with flaws, errors and/or inefficiencies in the use of scientific knowledge by decision-makers in decision-making and practical actions. Sentences, together with its context, indicate these flaws, errors and/or inefficiencies are deemed to hinder or prevent decision-making and practical actions from being based on scientific knowledge.

Sentences, together with its context, indicate the causes of the science-practice gap lie on the fact the scientific knowledge that reaches decision-makers is disregarded in decision-making and practical actions.

Sentences, together with its context, indicate the causes of the science-practice gap lie on the fact decision-makers themselves reject and/or disregard the use of scientific knowledge in practice, either because they see no necessity for it, because they are resistant to change their habits, because they prefer to use their previous experiences and personal knowledge, because their values, beliefs and attitudes towards science are negative, or because they do no trust the knowledge source.

Sentences indicate the causes of the science-practice gap lie on the fact the organizational and/or institutional structure of practice forces decisionmakers to disregard scientific knowledge in decisionmaking and practical actions, because of legislative factors, bureaucratic mechanisms of the organizations,
"Unfortunately, the production and publication of new rigorous science alone cannot overturn entrenched management paradigms that have gone unchallenged. Ideas fostered by sound research are not always accepted and used by managers, especially when new ideas contradict dogmatic beliefs. Nonetheless, there is a paucity of published accounts on why research results are not incorporated into management activities (...)” (McCleery et al., 2007, p. 2134)

“Limitations identified by 30 elephant managers.

\section{(...)}

Organisational culture. The workplace culture within some organisations does not promote reliance on science findings for management decision making. Specifically the link between scientists and managers is vulnerable to personality differences." (Young \& Van Aarde, 2011, p. 882) 
or lack of time available in day-to-day activities to take ownership and use scientific knowledge. ${ }^{9}$

$1313 \quad$ Other disregards

$1320 \quad$ Knowledge selected

Other problems in knowledge use

Sentences indicate the causes of the science-practice gap lie on the fact the scientific knowledge that reaches decisionmakers is disregarded in decision-making and practical actions, but the appointed cause does not fit in any of the lowerlevel categories of "Knowledge disregarded" mentioned above.

Sentences indicate the causes of the science-practice gap lie on the fact the body of scientific knowledge reaching practice is selected, misused or partially used to support interests of decision-makers, who ignore scientific knowledge that clashes with their interests, impeding and/or preventing decision-making and practical actions from being based in the totality of scientific knowledge relevant to each question.

Sentences indicate the causes of the science-practice gap lie on the fact other factors (e.g., political and economic interests or values and beliefs of social groups involved) can be given more weight in decision-making and practical actions than scientific knowledge. In other words, these factors outweigh or surpass scientific knowledge, even if the decisionmaker or the organizational structure does not reject it.

Sentences indicate the causes of the science-practice gap are associated with flaws, errors and/or inefficiencies in the use of scientific knowledge by decision-makers that are deemed to hinder or prevent decision-making and practical actions from being based on scientific knowledge, but the appointed cause does not fit in any of the third-level categories of "Problems in knowledge use" mentioned above.
"Unaligned research, from which one gains knowledge that might not be of immediate interest to policy makers, tends to facilitate the transition of research issues to the domain of partisanship. Research may be used symbolically in partisan ways by advocates of particular viewpoints or values or by policy entrepreneurs. Alternatively, unaligned research may simply languish." (Rudd, 2011, p. 863)

"Marine management usually includes regulations about the distribution of the resource among users, access to resources, quotas and territorial or resource property rights. So far, sociopolitical (economic) forces have dominated policies to manage resources, to the detriment of population, community or ecosystem ecological knowledge." (Castilla, 2000, p. 5)

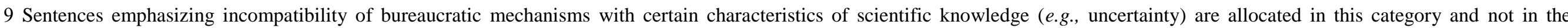

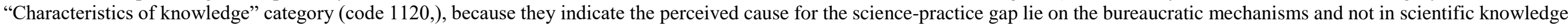
itself. 
Problems in the feedback from practice

Lack of communication of practical results

\section{General problems}

1510

Other problems in the feedback from practice
Sentences indicate the causes of the science-practice gap are associated with flaws, errors and/or inefficiencies in the feedback of research needs and practical results from practice to science. Sentences, together with its context, indicate these flaws, errors and/or inefficiencies are deemed to hinder or prevent decision-making and practical actions from being based on scientific knowledge.

Sentences indicate the causes of the science-practice gap lie on the fact results from decision-making and practical actions are not communicated and/or published, hampering and/or preventing learning from past decisions and actions based on scientific knowledge.

Sentences indicate the causes of the science-practice gap lie on the fact decision-makers do not communicate their needs to science or do not ask scientists for help, hampering the generation of adequate knowledge to practice.

"There are many reasons why this implementation gap exists. A high proportion of papers published in scientific journals by conservation biologists are seldom read outside of the academic world (...). In turn, field practitioners rarely document their field experiences and experiments in a manner that can meaningfully inform conservation scientists. "(Sunderland et al., 2009, p. 549)

“(...) as Montrey (1991) candidly remarks, "we (researchers) didn't do a good enough job of telling our story, and more importantly, we didn't do a good enough job of listening to those whose lands these are." It is our view also that land managers have not always done a good job explaining their needs or soliciting research help." (Finch \& Patton-Mallory, 1993, p. 13)
Sentences indicate the causes of the science-practice gap are associated with flaws, errors and/or inefficiencies in the feedback of research needs and practical results from practice to science that are deemed to hinder or prevent decisionmaking and practical actions from being based on scientific knowledge, but the appointed cause does not fit in any of the third-level categories of "Problems in the feedback from practice" mentioned above.

Sentences indicate the causes of the science-practice gap are associated with flaws, errors and/or inefficiencies perceived to affect the whole process of unidirectional flow of knowledge from science to practice (including generation and publication of relevant knowledge, knowledge communication with or without personal interactions, and/or knowledge use). Sentences, together with its context, indicate these flaws, errors and/or inefficiencies are deemed to hinder or prevent decision-making and practical actions from being based on scientific knowledge.

Sentences indicate the causes of the science-practice gap lie on cultural aspects of science and practice, related to behaviors, negative attitudes or misguided perceptions towards each other, or on cultural differences between science and practice in terms of
"Hence, in South Africa, the "implementation gap" between elephant managers and scientists may also be being fuelled by a lack of understanding by each party regarding the others needs and perceptions. This may not be surprising because most scientists are evaluated on the basis of their ability to produce 
language, values, expectations, working routines and/or carrier aspirations, that are deemed to hinder or prevent any of the processes of the unidirectional flow of knowledge from science to practice.

Difficulties associated with the organizational context

Sentences indicate the causes of the science-practice gap lie on characteristics of the organizations of science and/or practice, involving rules and structures establishing which activities are viable, legitimate and rewarded in each organization. Sentences, together with its context, indicate these organizational aspects are deemed to hinder or prevent acting in any of the processes of the unidirectional flow of knowledge from science to practice.

Sentences indicate the causes of the science-practice gap lie on the evaluation and reward systems of scientists (including the publication system on which this evaluation depend) and/or of decision-makers, which do not consider engaging in any of the processes of the unidirectional flow of knowledge from science to practice as integral part of professional activities, either by seeing it as illegitimate forms of acting or by not allowing time for them.

Sentences indicate the causes of the science-practice gap lie on the fact formal education, together with the organizational context regulating this education, does not prepare professionals to engage in any of the processes of the unidirectional flow of knowledge from science to practice, i.e., forms scientists unable to conduct relevant research, disseminate and/or translate produced knowledge, but also professionals with no skills to comprehend, synthesize and/or use knowledge in practice.

Sentences indicate the causes of the science-practice gap lie on the lack of resources or on the incompatibility of funding schemes to support the engagement of scientists and/or decision-makers in refereed publications rather than the ability to recover species or restore ecosystems." (Young \& Van Aarde, 2011, p. 883)
"A third barrier to bridging the Research-Implementation Gap is that research scientists are given little positive incentive to educate landowners and management agencies about their findings. Most university promotion systems are built upon researchers obtaining grant funds and publishing articles in highly cited research journals, instead of measuring whether research is translated into meaningful conservation action" (Courter, 2012, p. 63)

"Formal scientific education rarely exposes students to the policy-making process and does not explain the methods, metrics or workings of the policy-developing elements of the civil service or government agencies. A failure to understand this and to appreciate the attitudes and needs of policy developers will greatly hamper the dissemination of hard-won research knowledge." (Bainbridge, 2014, p. 1153)

"Students cope with problems that established researchers also face, such as limited interdisciplinary training (...) and lack of institutional support for the application of findings. When limited research funding is available, students may be forced to limit 
any of the processes of the unidirectional flow of knowledge from science to practice. their research scope and exclude activities promoting application of results." (Pietri et al., 2013, p. 2)
Other difficulties associated with the organizational context

Difficulties associated with models of science and of science-practice linkages

Post-normal science

Neutral science
Other models

Sentences indicate the causes of the science-practice gap lie on characteristics of the organizations of science and/or practice that are deemed to hinder or prevent acting in any of the processes of the unidirectional flow of knowledge from science to practice, but the appointed cause does not fit in any of the lower-level categories of "Difficulties associated with the organizational context" mentioned above.

Sentences indicate the causes of the science-practice gap lie on current predominant models governing scientific production and the linkage between science and practice that are deemed to hinder or prevent any of the processes of the unidirectional flow of knowledge from science to practice.

Sentences indicate the causes of the science-practice gap lie on a model of the linkage between science and practice that assumes all forms of knowledge (and not only scientific knowledge) are equally valid to solve practical problems, devaluing scientific knowledge, scientists' opinions and the use of scientific knowledge in decision-making and practical actions.

Sentences indicate the causes of the science-practice gap lie on a model of science that assumes science must be neutral and objective, without any influence of issues from outside the academic world.
“(...) why has there been only incomplete application of environmental science? An overriding cause may be societal evolution away from the modernist "Sputnik Era', in which conventional science institutions were granted societal authority for the creation of knowledge, toward post-modernist societies in which different forms of scholarly knowledge compete, and the primacy and even the credibility of scientific knowledge is questioned". (Nassauer \& Opdam, 2008, p. 634)

"Much of the notion that science will lose its objectivity and independence in the face of application comes from concern that user agencies will "dictate" the nature and outcome of research, and that this will therefore not be "cutting edge." This is not a problem of either science or application, but of the honesty and objectivity of the parties involved (...)." (Roux et al., 2006, p. 16)

Sentences indicate the causes of the science-practice gap lie on current predominant models governing scientific production and the linkage between science and practice, but the appointed cause does not fit in any of the lower-level categories of "Difficulties associated with models of science and of science-practice linkages" mentioned above. 
Sentences indicate the causes of the science-practice gap lie on the complexity of problems faced in practice, involving diverse systems interacting with each other (e.g., natural and social systems) and Complexity of problems changing over time. Sentences, together with its context, indicate this complexity is deemed to hamper any scientific and/or practical activity related to the unidirectional flow of knowledge from science to practice.

Sentences indicate the causes of the science-practice gap are associated with flaws, errors and/or inefficiencies affecting the whole process of unidirectional flow of knowledge from science to practice that are deemed to hinder or prevent decision-making and practical actions from being based on scientific knowledge, but the appointed cause does not fit in any of the third-level categories of "General problems" mentioned above.

Sentences, together with its context, indicate a perspective on the linkage between science and practice in which only scientific knowledge is considered important to support decision-making and practical actions, but the appointed cause does not fit in any of the second-level categories of the "One knowledge" perspective mentioned above.

Sentences, together with its context, indicate a perspective on the linkage between science and practice in which both should contribute with knowledge to support decision-making and practical actions, therefore stablishing a collaborative process of knowledge production and integration via interactions, exchanges, partnerships and/or dialogue between science and practice. For this perspective, the causes of the science-practice gap are associated with perceived problems in this interactive process between science and practice, and the interaction is understood as a process with intellectual contribution of both parts involved (science and practice), rather than a process that facilitates the transfer of scientific knowledge. ${ }^{10}$

\section{TWO KNOWLEDGES}

"Compared to the atmospheric and ocean disciplines, terrestrial research. This is due to many factors, including institutional
renting constraints, but looming large is the simple fact that human beings inhabit the land and their environmental, social and economic interactions are extremely complex." (Norse \&

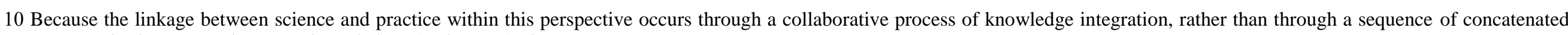

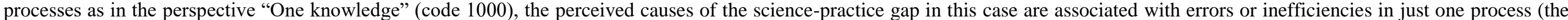

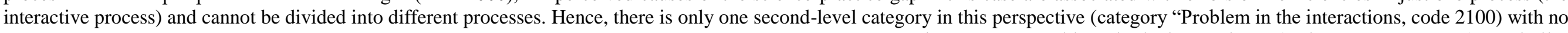

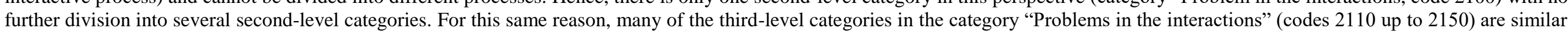

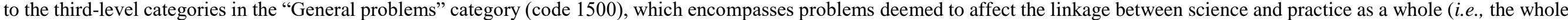
process of unidirectional flow of knowledge). 
$2100 \quad$ Problems in interactions

Lack of interactions

Epistemological difficulties
Sentences indicate the causes of the science-practice gap are associated with absences, flaws, errors and/or inefficiencies perceived to affect the whole interaction process between science and practice. Sentences, together with its context, indicate these flaws, errors and/or inefficiencies are deemed to hinder or prevent interactions, exchanges, partnerships, dialogue and/or collaborations between science and practice.

"Recent articles in (...) highlight a Research-Implementation Sentences indicate the causes of the science-practice gap lie on the lack of interactions, exchanges, partnerships, dialogue and/or collaborations between science and practice, but without delving into the reasons behind this absence.

Sentences indicate the causes of the science-practice gap lie on epistemological aspects of science and/or practice, including the nature of knowledge, the processes of generating knowledge (i.e.. types of inference, approaches, methods, investigation questions and/or interpretation of reality), the types of knowledge and generation processes deemed valid, and/or on differences between science and practice regarding these epistemological aspects, that are perceived to hinder or prevent interactions between science and practice.

Sentences indicate the causes of the science-practice gap lie on cultural aspects of science and practice, related to behaviors, negative attitudes or misguided perceptions towards each other, or on cultural differences between science and practice in terms of language, values, expectations, organizational contexts and working routines, that are deemed to
Gap that exists in conservation biology (..). Many facets of this problem have been identified, including a lack of knowledgesharing between researchers and practitioners, a lack of access by practitioners to information, and a disconnect between conservation research and realistic implementation goals (...)" (Courter, 2012, p. 62)

“(...) disagreements [between science and practice] are basically interpreted as conflicts between different rationalities and social positions. Cognitive conflicts may stem from fundamental differences in the ways scientific and lay persons observe and interpret their environments (...). Both lay knowledge and scientific knowledge possess strengths and limitations and cannot be exchanged for each other" (Peuhkuri, 2002, p. 160)

“(...) a deep rift that has been perpetuated by years of misunderstandings and misconceptions of each other's roles and responsibilities. Stereotyping of both managers and scientists

is sometimes used in a humiliating or manipulative way, further exacerbating the problem. (...)" (Roux et al., 2006, p. 3) 
hinder or prevent interactions between science and practice. ${ }^{11}$

Difficulties associated with the organizational context

\section{$2141 \quad$ Evaluation systems}

Formal education

Sentences indicate the causes of the science-practice gap lie on characteristics of the organizations of science and/or practice, involving rules and structures establishing which activities are viable, legitimate and rewarded in each organization, that are deemed to hinder or prevent interactions between science and practice.

Sentences indicate the causes of the science-practice gap lie on the evaluation and reward systems of scientists and decision-makers, which do not consider (or do not allow time for) engaging in interactions, exchanges, partnerships, dialogues or collaborations as an integral part of professional activities, as well as do not value the knowledge produced from these interactions.

Sentences indicate the causes of the science-practice gap lie on the fact formal education does not prepare scientists and decision-makers to act in an integrated manner.

Sentences indicate the causes of the science-practice gap lie on the lack of resources or on the incompatibility of funding schemes to support interactions, exchanges, partnerships, dialogue or collaborations between science and practice.
"Learning together, through sharing content as well as contexts, fosters much needed shared understanding of the concepts, principles, and approaches relevant to the respective domains [domain of science and domain of management/policy]. This is especially hard for scientists who may be rewarded for staying in their chosen field, but it is also difficult for managers and policy makers who cannot afford to be seen not to know." (Roux et al., 2006, p. 11)

"Opportunities for social learning are not restricted to the planning and dissemination stages, but also within the other stages too. However, this is where the researchers' skills and disciplinary training come to the fore, which often purposefully or accidentally exclude dialogue, participation and learning with other stakeholders because of the barriers posed by jargon, theoretical frameworks, complex measuring approaches or instruments and statistical presentation of results." (Shackleton et al., 2009, p. 564)

"Involvement of multiple role-players in active decision-making in natural resource management tends to dissipate when funding is both rigidly orientated and short-term. The complexities and dynamic nature of both social and ecological systems mean that surprise is the norm. Funding streams need to be opportunistic, flexible and adaptive (...)." (Shackleton et al., 2009, p. 566)

11 Sentences that only point out cultural differences, without explaining on what cultural aspect the relevant difference reside are also included in this category. 
“(...) it is important to engage as many people as possible in the

Sentences indicate the causes of the science-practice gap lie on a high turnover of decision-makers' employment positions in the organizations involved in practice, impeding fruitful interactions with the scientific community.

High turnover in practice

Other difficulties

2145 associated with the organizational context

Difficulties associated with models of science and of science-practice linkages

Linear model

Model emphasizing scientific rigor/quality organizational context" mentioned above. practice.

Sentences indicate the causes of the science-practice gap lie on a model of the linkage between science and practice that assumes a unidirectional flow of knowledge from science to practice.

Sentences indicate the causes of the science-practice gap lie on a model of the linkage between science and practice that assumes the science-practice gap is due only to a lack of scientific rigor and the solution to
Sentences indicate the causes of the science-practice gap lie on characteristics of the organizations of science and/or practice, but the appointed cause does not fit in any of the lower-level categories of "Difficulties associated with the

Sentences indicate the causes of the science-practice gap lie on current predominant models governing scientific production and the linkage between science and practice that are deemed to hinder or prevent interactions between science and

"Science is commonly depicted at the "upstream" end of a oneway process by which useful discoveries and inventions eventually "flow" to an application home. Although this may be the dominant direction of knowledge flow during the development of new technological capability, its successful adoption and implementation is highly dependent on the bi-directional flow of knowledge between science and management." (Roux et al., 2006, p. 16) environmental problems lies on a science of better quality.
"(...) The most critical step in the processes for improving understanding is to discard the naïve scientific presumption that "good science" should be the starting point for "good management". This is a deadly and wasteful intellectual trap into which scientists repeatedly fall." (Walters, 1998, p. 281) 
Sentences indicate the causes of the science-practice gap lie on a model of knowledge production that values only explicit, objective and impartial (i.e., value-free) knowledge and disregard other knowledge types, e.g., experience-based or tacit knowledge (knowledge that is subjective, hard to formalize and deeply connected to world views, values and personal experiences).

"By recognizing only the explicit character of knowledge, we underestimate the true effort required to transfer knowledge. Information or explicit knowledge can be passed on to others relatively easily; the transfer of associated tacit dimensions requires intimate human interaction. People need to spend time together, develop mutual trust, learn more about each other's contexts and jointly facilitate conversions of knowledge between tacit and explicit forms" (Roux et al., 2006, p. 7)

Sentences indicate the causes of the science-practice gap lie on current predominant models governing scientific production and the linkage between science and practice, but the appointed cause does not fit in any of the lower-level categories of "Difficulties associated with models of science and of science-practice linkages" mentioned above.

Sentences indicate the causes of the science-practice gap are associated with absences, flaws, errors and/or inefficiencies affecting the whole interaction process between science and practice that are deemed to hinder or prevent interactions, exchanges, partnerships, dialogue and/or collaborations between science and practice, but the appointed cause does not fit in any of the third-level categories of "Problems in the interactions" mentioned above.

Sentences, together with its context, indicate a perspective on the linkage between science and practice in which both should contribute with knowledge to support decision-making and practical actions, but the appointed cause does not fit in any of the second-level categories of the "Two knowledges" perspective mentioned above.

Sentences, together with its context, indicate a perspective on the linkage between science and practice in which only scientists are important actors any of the major perspectives mentioned above. and should act in practice, besides producing scientific knowledge. For this perspective, the perceived causes of the science-practice gap are associated with scientist not performing practical activities or facing difficulties in performing them.

Sentences, together with its context, indicate a perspective on the linkage between science and practice that does not fit in

"Researchers dealing with conservation subjects usually do not put the results of their work into practice, even when the primary purpose of their research is the preservation of biodiversity." (Gallo et al., 2009, p. 895) 
A

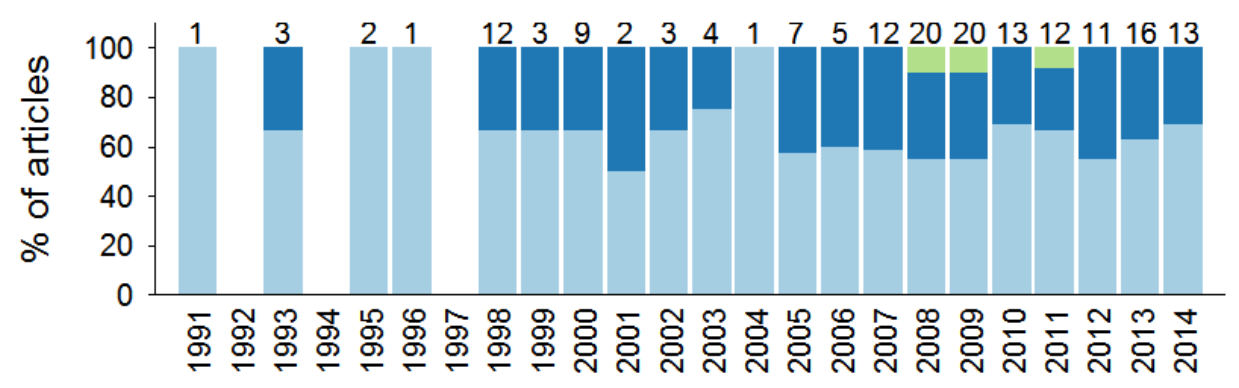

C

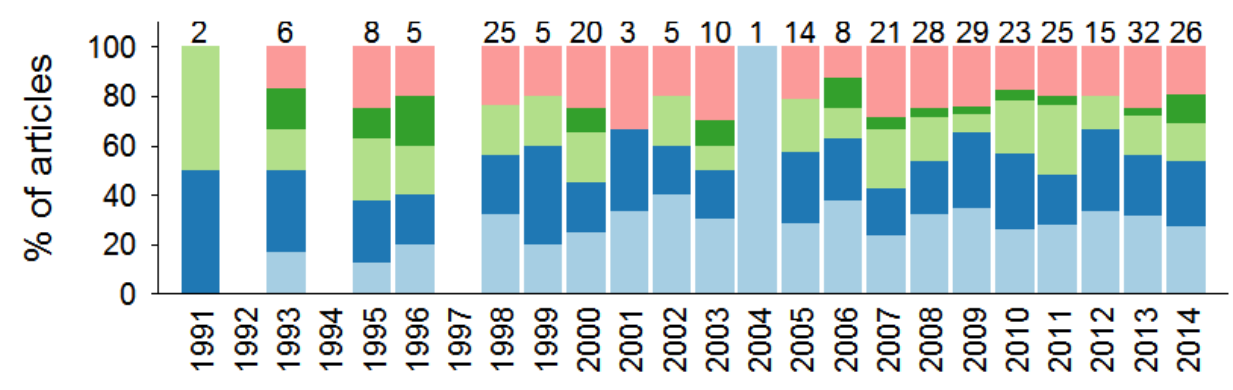

E

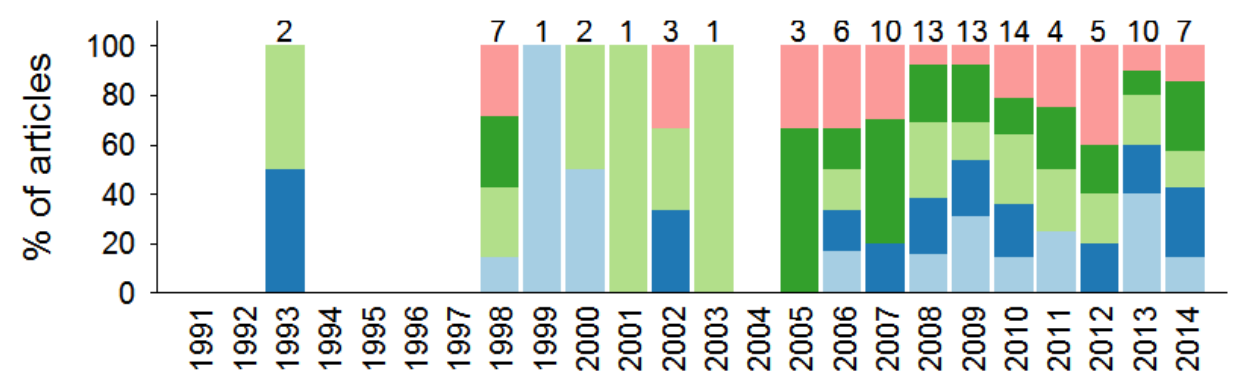

\section{Publication year}

\section{Publication year}

$\mathbf{B}$

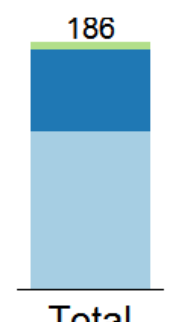

Total

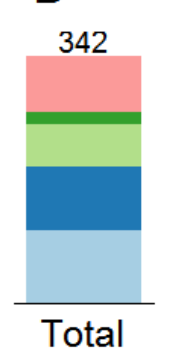

Major Categories One Knowledge Two Knowledges One Actor

\section{Publication year}

Figure S2. Relative proportion of articles including each category of perceived causes of the science-practice gap in Ecology and Conservation divided by publication years (A, C and E) and in total (B, D and F). Major categories/ perspectives (A-B), categories of the "One knowledge" perspective (C-D), categories of the "Two knowledges" perspective (E-F). Because one article can include more than one category of perceived causes, the number above bars is greater than the total number of articles for each year or category. 
A

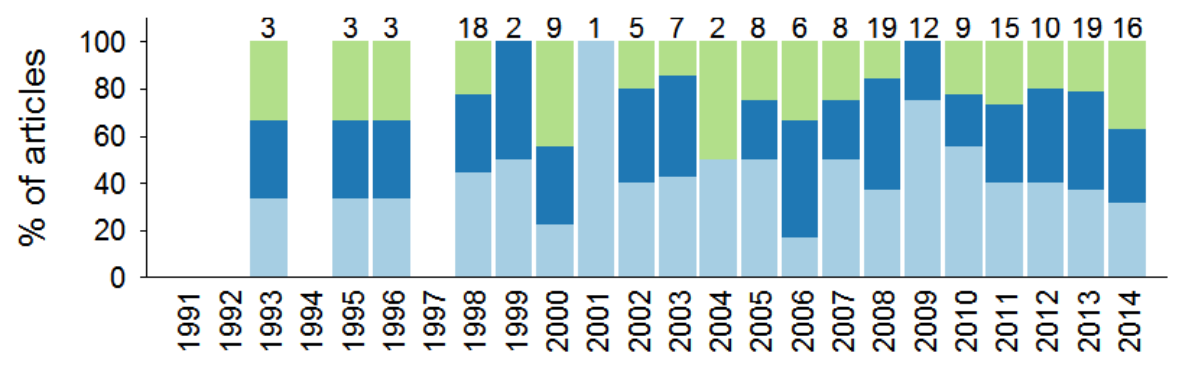

Publication year

\section{C}

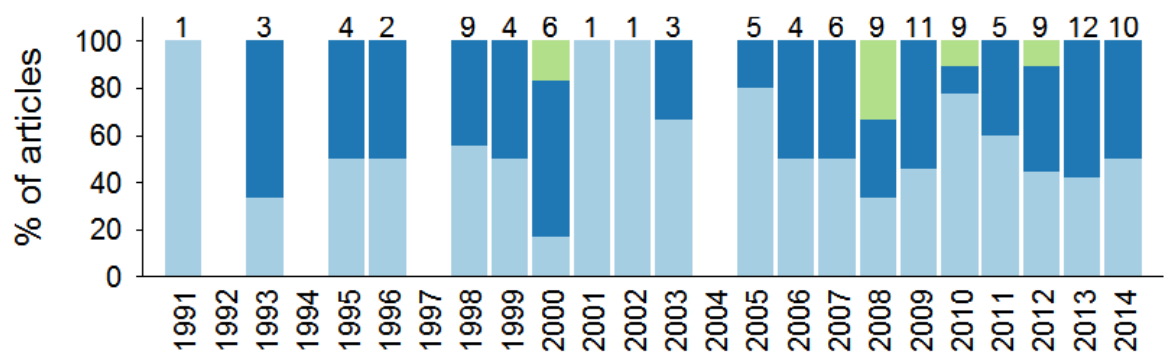

E

Publication year

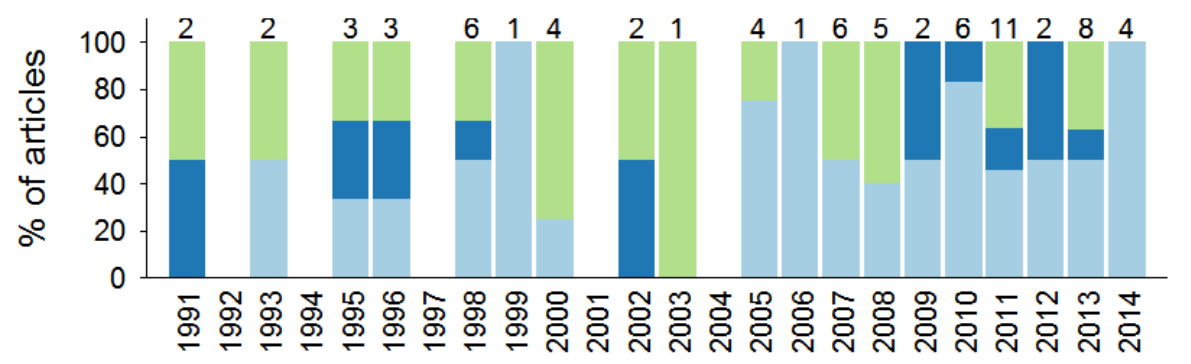

Publication year

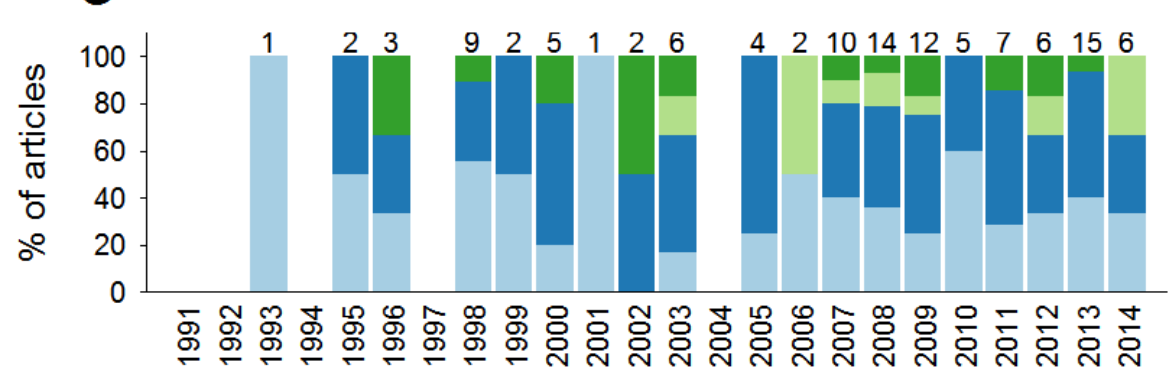

B

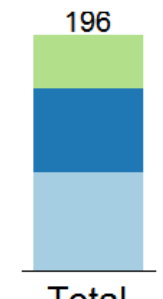

Knowledge

Generation

Flawed or

inefficient research

Characteristics of

knowledge

Knowledge gaps

Total

\section{D}

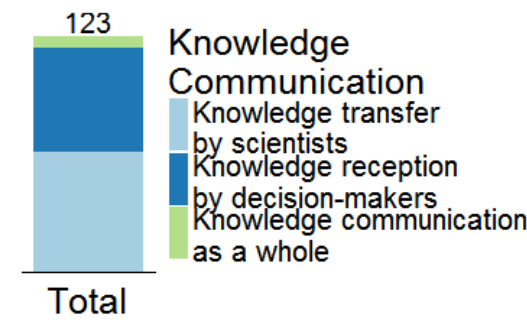

F

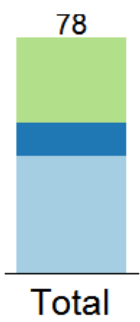

Knowledge Use

Knowledge disregarded

Knowledge selected

Knowledge surpassed

\section{H}

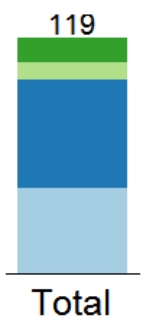

General Problems

Cultural difficulties

Difficulties in the

orqanizational context

Difficulties in

models of science

Complexity of problems

Total

\section{Publication year}

Figure S3. Relative proportion of articles including each category of perceived causes of the science-practice gap in Ecology and Conservation divided by publication years (A, C, E and G) and in total (B, D, F and G). Lower-level categories of "Problems in knowledge generation" (A-B), lower-level categories of "Problems in knowledge communication" (C-D), lower-level categories of "Problems in knowledge use" (E-F), lower-level categories of "General problems" (G-H). The category "Problems in the feedback from practice" presented too few articles to allow division into years and therefore is not presented in this figure. Because one article can include more than one category of perceived causes, the number above bars is greater than the total for each year or category. 


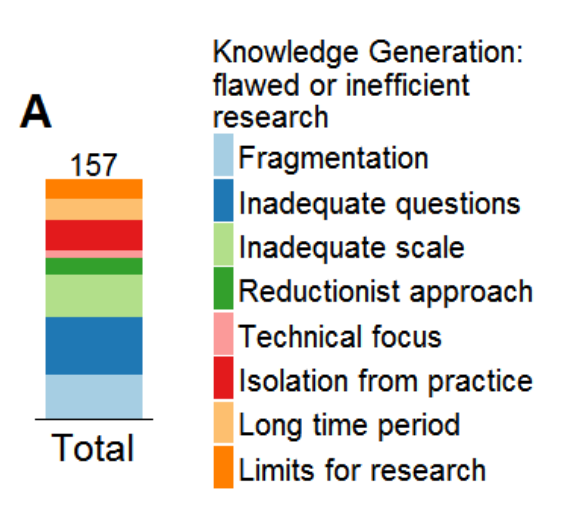

D

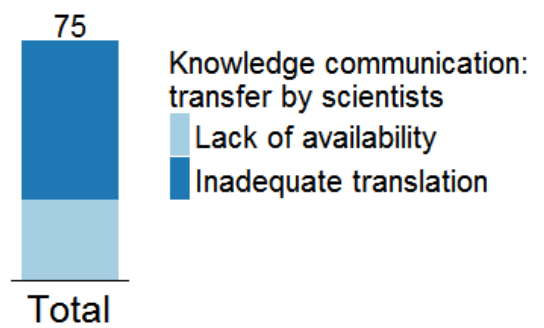

G

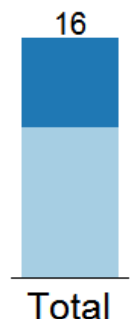

Feedback from Practice Lack of communication of practical results Lack of communication of practical needs
E

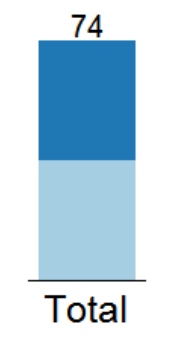

Knowledge Generation: characteristics of

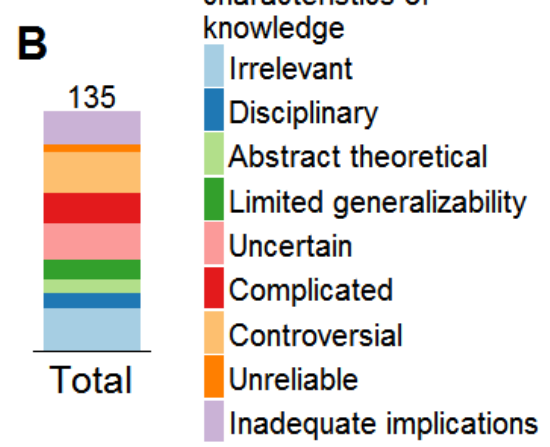

C

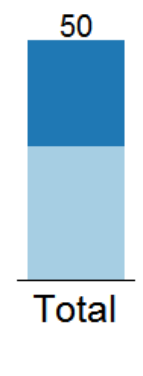

Knowledge Generation: knowledge gaps

Lack of knowledge

Lack of implications
$\mathbf{F}$

Knowledge Communication: reception by decision-makers Lack of access Difficulty in understanding

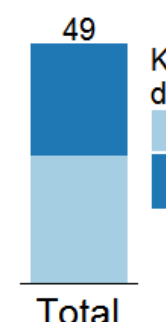

Knowledge use: disregarded Rejection by decision-makers Impediment by the organizational structure
H

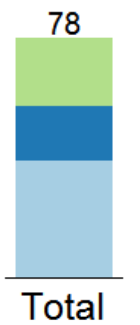

General Problems: difficulties in the organizational context Evaluation systems Formal education Resources
I

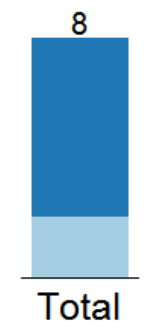

General problems: difficulties in models of science

Post-normal science

Neutral science

Figure S4. Relative proportion of articles including each lower-level category of perceived causes of the sciencepractice gap in Ecology and Conservation within third-level categories of the perspective "One knowledge". In knowledge generation: lower-level categories of "Flawed or inefficient research" (A), of "Characteristics of knowledge or implications" (B) and of "Knowledge gaps" (C). In knowledge communication: lower-level categories of "Problems in knowledge transfer by scientists" (D) and of "Problems in knowledge reception by decision-makers" (E). In knowledge use: lower-level categories of "Knowledge disregarded" (F). In feedback from practice: direct lower-level categories (G). In "General problems": lower level categories of "Difficulties associated with the organizational context" (H) and of "Difficulties associated with models of science and science-practice linkages" (I). Because one article can include more than one category of perceived causes, the number above bars is greater than the total number of articles for each category. 
A

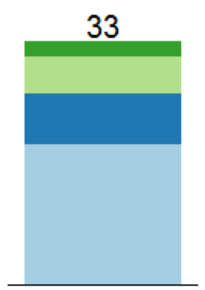

Total

(1)
B

Problems in Interactions: difficulties in the organizational context Evaluation systems

Formal education

Resources

High turnover in practice

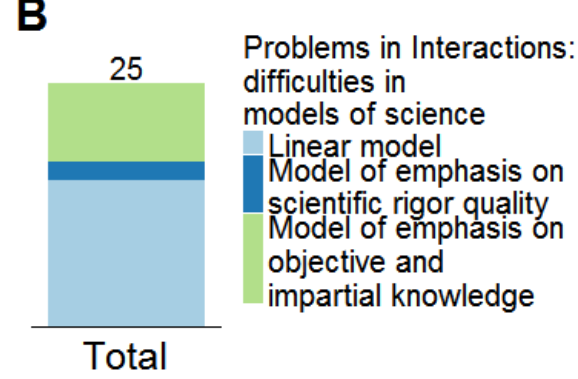

Figure S5. Relative proportion of articles including each lower-level category of perceived causes of the sciencepractice gap in Ecology and Conservation within the third-level categories of the perspective "Two knowledges". In "Problems in interactions": lower-level categories of "Difficulties associated with the organizational context" (A) and of "Difficulties associated with the models of science and science-practice linkages" (B). Because one article can include more than one category of perceived causes, the number above bars is greater than the total number of articles for each category. 


\section{Appendix S8 - Research results after excluding the 21 articles that investigated empirically the opinions of scientists and/or decision-makers.}

A

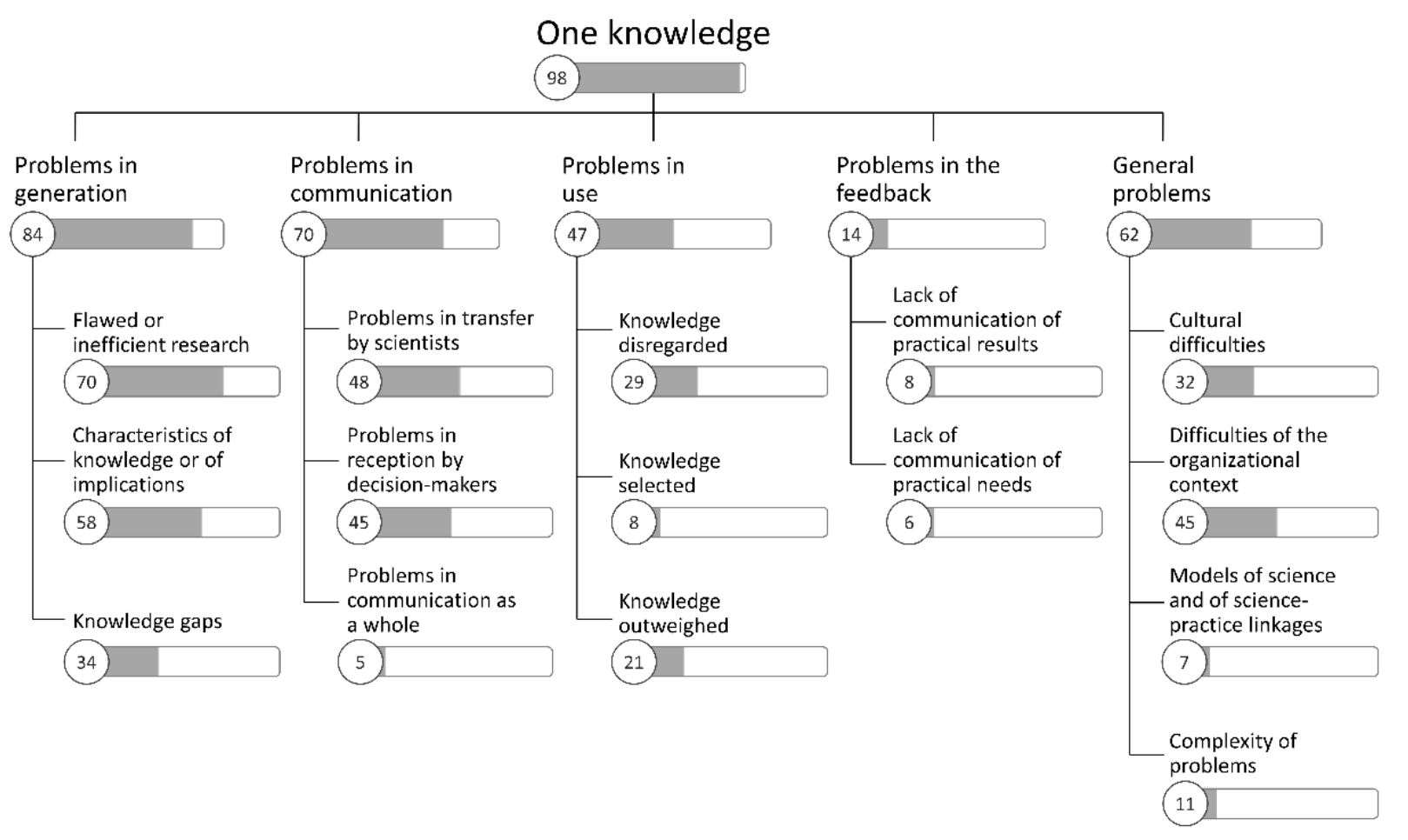

B

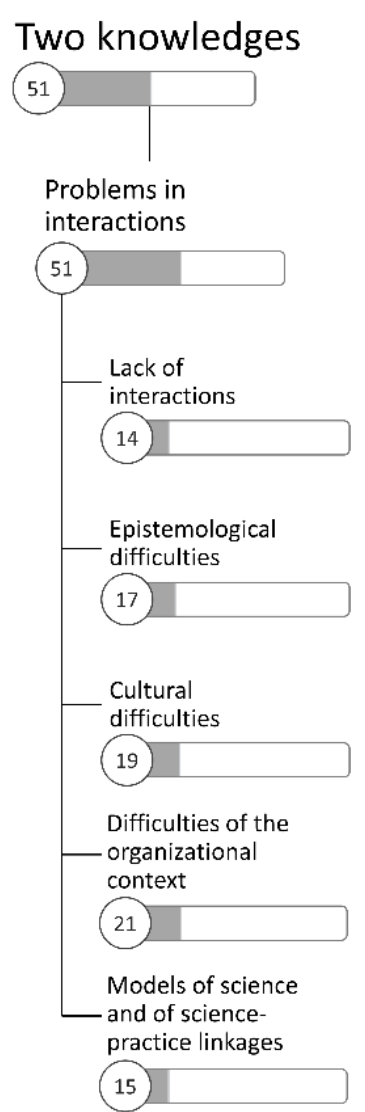

Figure S6. Hierarchical organization of the second- and third-level categories of perceived causes of the science-practice gap in Ecology and Conservation within the perspectives "One knowledge" (A) and "Two knowledges" (B), showing the number (inside circles) and the proportion (bars) of articles that contained sentences allocated to each category (excluding those articles that investigated empirically the opinions of scientists and/or decision-makers; $\mathrm{N}=101$ ). 


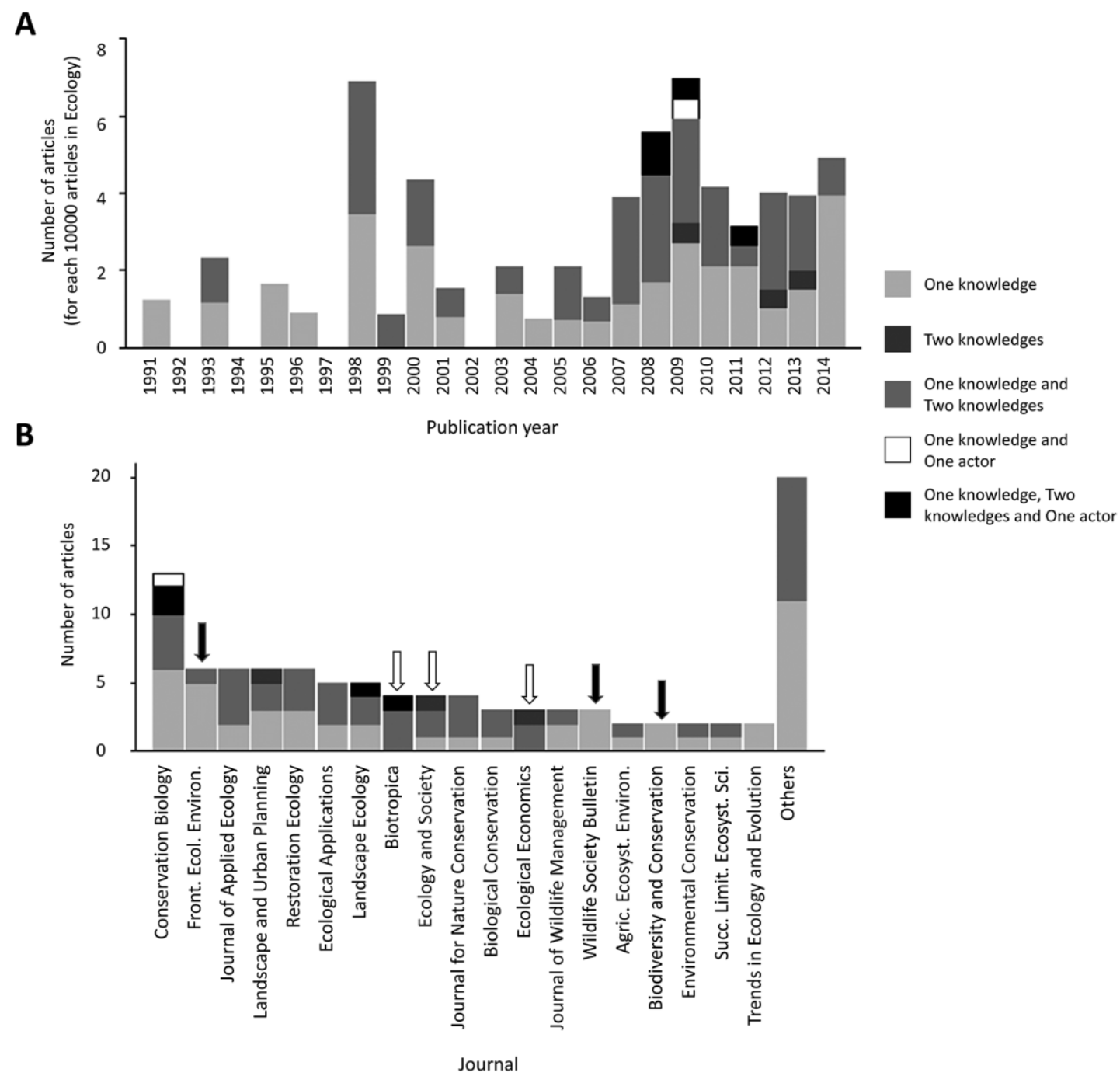

Figure S7. Distribution of reviewed articles (excluding those that investigated empirically the opinions of scientists and/or decision-makers; $\mathrm{N}=101$ ) associated with each major category of perceived causes of the science-practice gap in Ecology and Conservation over the years (A) and across scientific journals (B). Symbols and abbreviations are the same as Fig. 4 in the main text. 
Table S5. Number (\#) of articles (excluding those that investigated empirically the opinions of scientists and/or decision-makers; $\mathrm{N}=101$ ) containing sentences related to each category of the simplified version of the conceptual framework of perceived causes of the science-practice gap in Ecology and Conservation found in the scientific literature.

\section{Category}

\begin{tabular}{|c|c|c|c|c|}
\hline $\begin{array}{c}1^{\text {st }} \text { hierarchical } \\
\text { level }\end{array}$ & $\begin{array}{c}2^{\text {nd }} \text { hierarchical } \\
\text { level }\end{array}$ & $\begin{array}{c}3^{\text {rd }} \text { hierarchical } \\
\text { level }\end{array}$ & $\begin{array}{c}4^{\text {th }} \text { hierarchical } \\
\text { level }\end{array}$ & \# \\
\hline \multirow{29}{*}{$\begin{array}{l}\text { ONE } \\
\text { KNOWLEDGE }\end{array}$} & \multirow{19}{*}{$\begin{array}{l}\text { Problems in } \\
\text { knowledge } \\
\text { generation }\end{array}$} & \multirow{8}{*}{$\begin{array}{l}\text { Flawed or inefficient } \\
\text { research }\end{array}$} & Fragmentation & 25 \\
\hline & & & Inadequate questions & 31 \\
\hline & & & Inadequate scale & 22 \\
\hline & & & Reductionist approach & 10 \\
\hline & & & Technical focus & 5 \\
\hline & & & Isolation from practice & 18 \\
\hline & & & $\begin{array}{l}\text { Long time period for } \\
\text { scientific knowledge } \\
\text { generation }\end{array}$ & 13 \\
\hline & & & Limits for research & 13 \\
\hline & & \multirow{9}{*}{$\begin{array}{l}\text { Characteristics of } \\
\text { knowledge or of } \\
\text { implications }\end{array}$} & Irrelevant & 17 \\
\hline & & & Disciplinary & 6 \\
\hline & & & Abstract/theoretical & 7 \\
\hline & & & $\begin{array}{l}\text { Limited } \\
\text { generalizability }\end{array}$ & 10 \\
\hline & & & Uncertain & 19 \\
\hline & & & Complicated & 13 \\
\hline & & & Controversial & 19 \\
\hline & & & Unreliable & 2 \\
\hline & & & $\begin{array}{l}\text { Inadequate } \\
\text { implications }\end{array}$ & 14 \\
\hline & & \multirow{2}{*}{ Knowledge gaps } & Lack of knowledge & 22 \\
\hline & & & Lack of implications & 16 \\
\hline & \multirow{5}{*}{$\begin{array}{l}\text { Problems in } \\
\text { knowledge } \\
\text { communication }\end{array}$} & \multirow{2}{*}{$\begin{array}{l}\text { Problems in } \\
\text { knowledge transfer } \\
\text { by scientists }\end{array}$} & Limited availability & 19 \\
\hline & & & Inadequate translation & 36 \\
\hline & & \multirow{2}{*}{$\begin{array}{l}\text { Problems in } \\
\text { knowledge reception } \\
\text { by decision-makers }\end{array}$} & Lack of access & 29 \\
\hline & & & $\begin{array}{l}\text { Difficulty in } \\
\text { understanding }\end{array}$ & 30 \\
\hline & & $\begin{array}{l}\text { Problems in } \\
\text { communication } \\
\text { as a whole } \\
\end{array}$ & & 5 \\
\hline & \multirow{4}{*}{$\begin{array}{l}\text { Problems in } \\
\text { knowledge use }\end{array}$} & \multirow[b]{2}{*}{$\begin{array}{l}\text { Knowledge } \\
\text { disregarded }\end{array}$} & $\begin{array}{l}\text { Rejection by decision- } \\
\text { makers }\end{array}$ & 19 \\
\hline & & & $\begin{array}{l}\text { Impediment by the } \\
\text { organizational and/or } \\
\text { institutional structure }\end{array}$ & 17 \\
\hline & & Knowledge selected & & 8 \\
\hline & & $\begin{array}{l}\text { Knowledge } \\
\text { outweighed }\end{array}$ & & 21 \\
\hline & $\begin{array}{l}\text { Problems in the } \\
\text { feedback from } \\
\text { practice }\end{array}$ & $\begin{array}{l}\text { Lack of } \\
\text { communication of } \\
\text { practical results }\end{array}$ & & 8 \\
\hline
\end{tabular}




\section{Category}

\begin{tabular}{|c|c|c|c|c|}
\hline $\begin{array}{c}1^{\text {st }} \text { hierarchical } \\
\text { level }\end{array}$ & $\begin{array}{c}2^{\text {nd }} \text { hierarchical } \\
\text { level }\end{array}$ & $\begin{array}{c}3^{\text {rd }} \text { hierarchical } \\
\text { level }\end{array}$ & $\begin{array}{c}4^{\text {th }} \text { hierarchical } \\
\text { level }\end{array}$ & \# \\
\hline & & $\begin{array}{l}\text { Lack of } \\
\text { communication of } \\
\text { practical needs }\end{array}$ & & 6 \\
\hline & & Cultural difficulties & & 32 \\
\hline & & Difficulties & Evaluation systems & 32 \\
\hline & & associated with the & Formal education & 14 \\
\hline & & $\begin{array}{l}\text { organizational } \\
\text { context }\end{array}$ & Resources & 17 \\
\hline & $\begin{array}{l}\text { General } \\
\text { problems }\end{array}$ & $\begin{array}{l}\text { Difficulties } \\
\text { associated with }\end{array}$ & Post-normal science & 2 \\
\hline & & $\begin{array}{l}\text { models of science } \\
\text { and of science- } \\
\text { practice linkages }\end{array}$ & Neutral science & 4 \\
\hline & & $\begin{array}{l}\text { Complexity of } \\
\text { problems }\end{array}$ & & 11 \\
\hline \multirow{10}{*}{$\begin{array}{l}\text { TWO } \\
\text { KNOWLEDGES }\end{array}$} & \multirow{10}{*}{$\begin{array}{l}\text { Problems in } \\
\text { interactions }\end{array}$} & Lack of interactions & & 14 \\
\hline & & $\begin{array}{l}\text { Epistemological } \\
\text { difficulties }\end{array}$ & & 17 \\
\hline & & Cultural difficulties & & 19 \\
\hline & & \multirow{4}{*}{$\begin{array}{l}\text { Difficulties } \\
\text { associated with the } \\
\text { organizational } \\
\text { context }\end{array}$} & Evaluation systems & 15 \\
\hline & & & Formal education & 5 \\
\hline & & & Resources & 5 \\
\hline & & & $\begin{array}{l}\text { High turnover in } \\
\text { practice }\end{array}$ & 1 \\
\hline & & \multirow{3}{*}{$\begin{array}{l}\text { Difficulties } \\
\text { associated with } \\
\text { models of science } \\
\text { and science-practice } \\
\text { linkages }\end{array}$} & Linear model & 11 \\
\hline & & & $\begin{array}{l}\text { Model emphasizing } \\
\text { scientific rigor/quality }\end{array}$ & 2 \\
\hline & & & $\begin{array}{l}\text { Model emphasizing } \\
\text { objective and } \\
\text { impartial knowledge }\end{array}$ & 5 \\
\hline
\end{tabular}


A

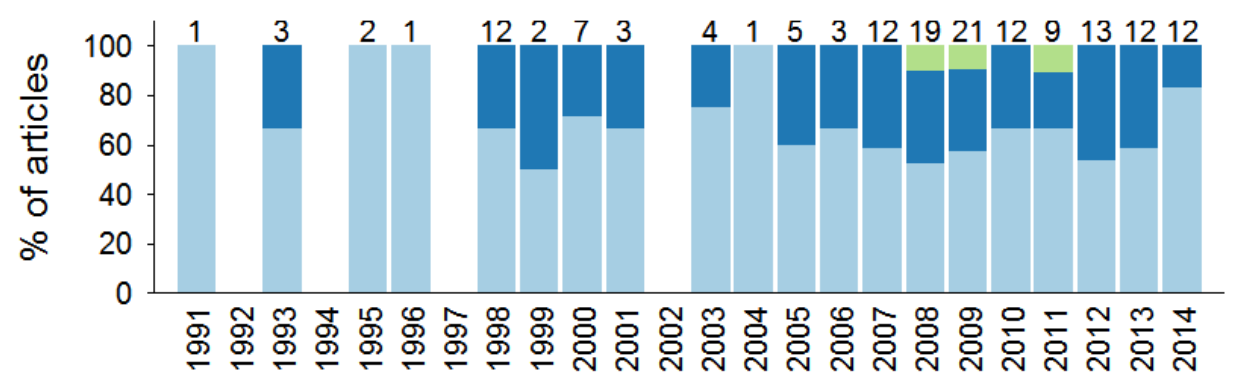

Publication year

C

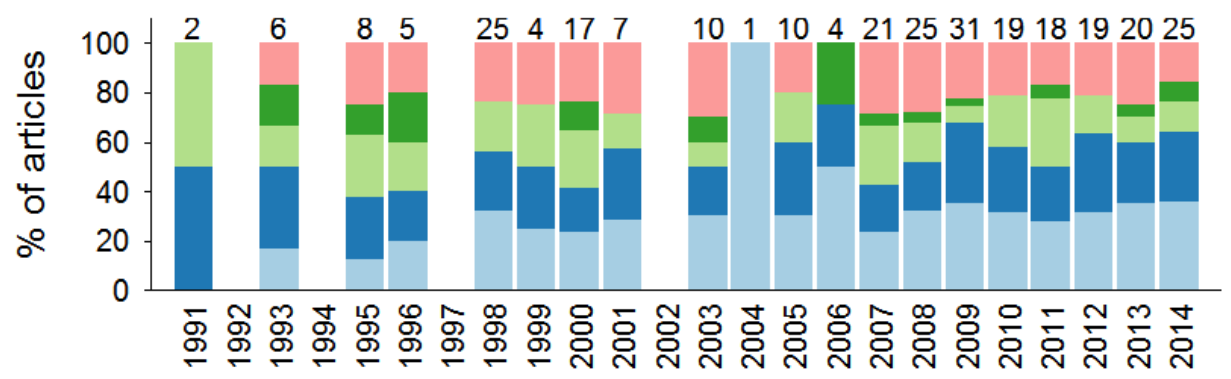

Publication year

\section{E}

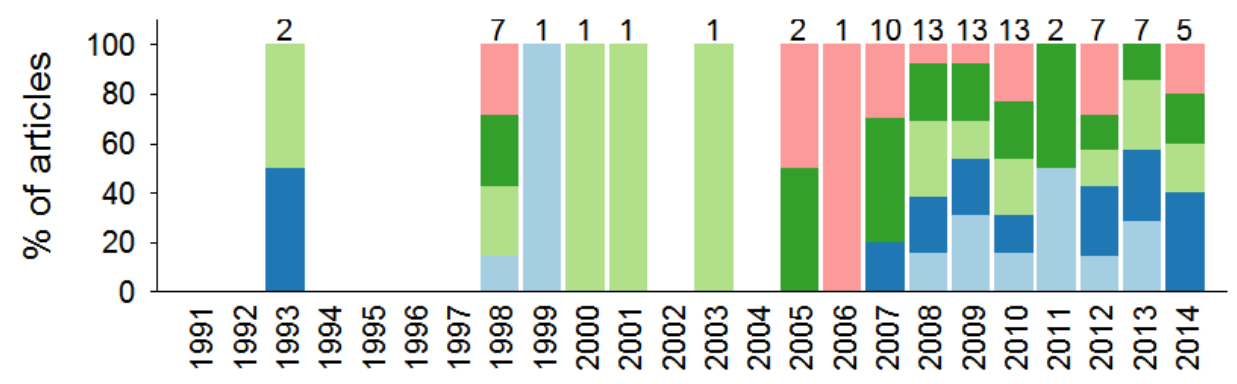

B

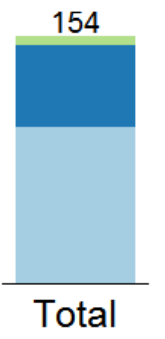

D

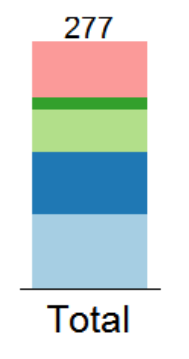

One Knowledge Knowledge Generation Knowledge Communication Knowledge Use Feedback from Practice General Problems

Major Categories

One Knowledge

Two Knowledges

One Actor

\section{Publication year}

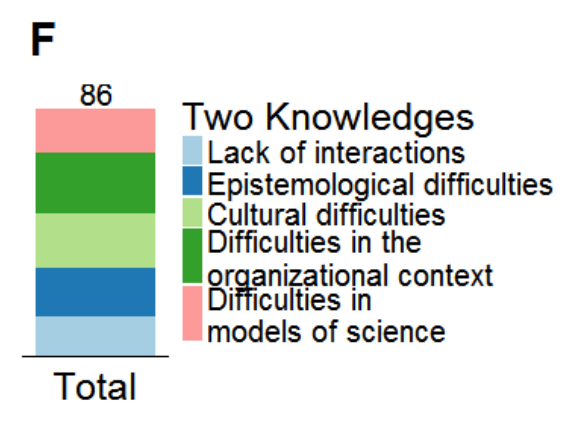

Figure S8. Relative proportion of articles (excluding those that investigated empirically the opinions of scientists and/or decision-makers) including each category of perceived causes of the science-practice gap in Ecology and Conservation divided by publication years (A, C and E) and in total (B, D and F). Major categories/ perspectives (A-B), categories of the "One knowledge" perspective (C-D), categories of the "Two knowledges" perspective (E-F). Because one article can include more than one category of perceived causes, the number above bars is greater than the total number of articles for each year or category. 
A

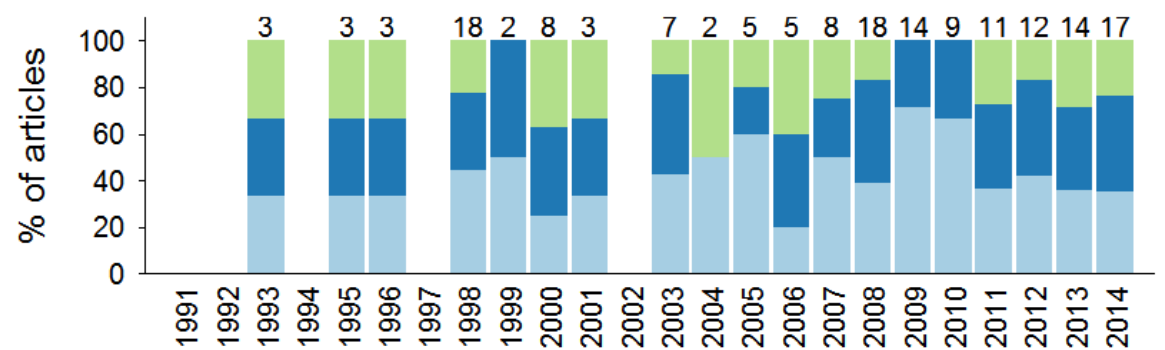

Publication year

C

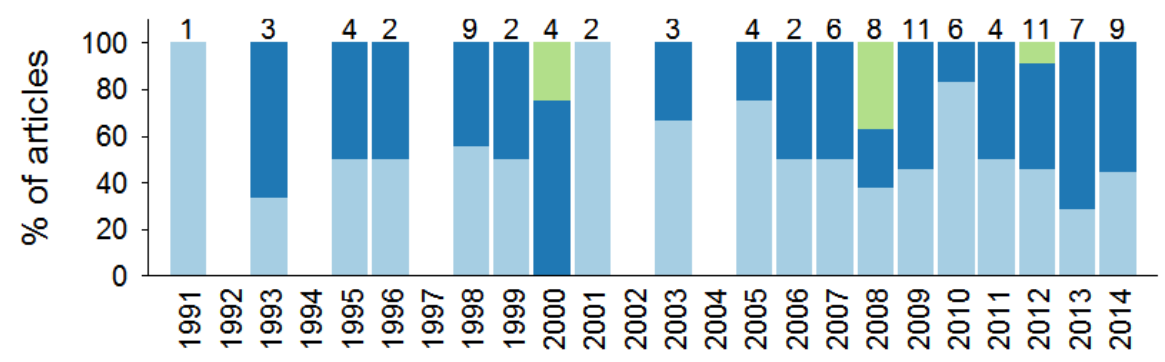

E

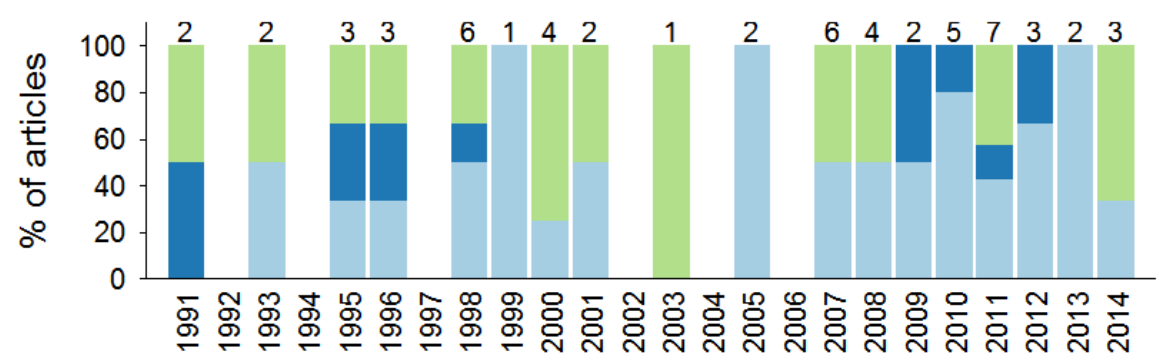

Publication year

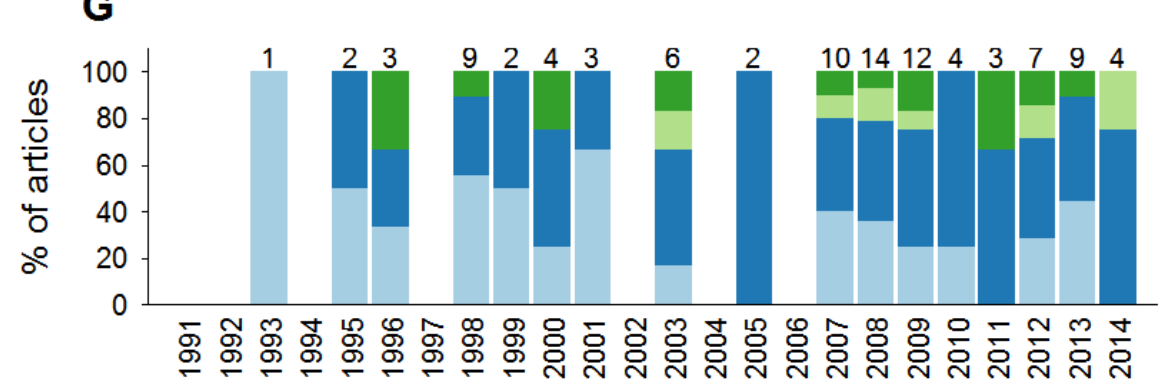

B

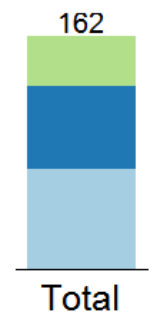

Knowledge

Generation

Flawed or

inefficient research

knowledge

Knowledge gaps

\section{D}

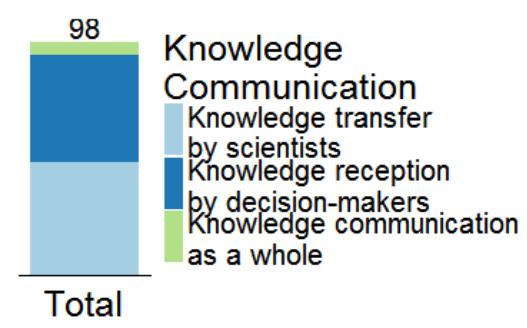

F

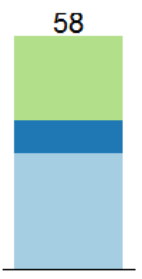

Total

H

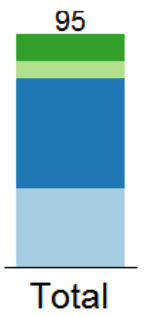

Knowledge Use Knowledge disregarded Knowledge selected Knowledge surpassed

\section{Publication year}

Figure S9. Relative proportion of articles (excluding those that investigated empirically the opinions of scientists and/or decision-makers) including each category of perceived causes of the science-practice gap in Ecology and Conservation divided by publication years (A, C, E and G) and in total (B, D, F and G). Lower-level categories of "Problems in knowledge generation" (A-B), lower-level categories of "Problems in knowledge communication" (C-D), lower-level categories of "Problems in knowledge use" (E-F), lower-level categories of "General problems" (G-H). The category "Problems in the feedback from practice" presented too few articles to allow division into years and therefore is not presented in this figure. Because one article can include more than one category of perceived causes, the number above bars is greater than the total for each year or category. 

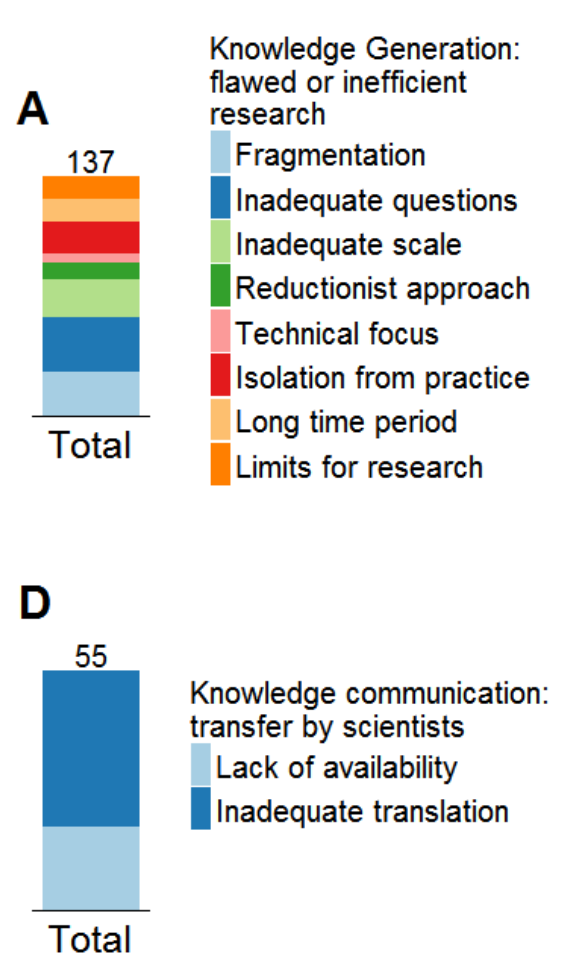

G

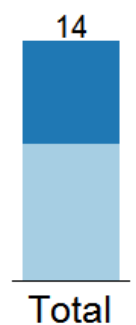

Feedback from Practice Lack of communication of practical results of practical needs Lack of communication

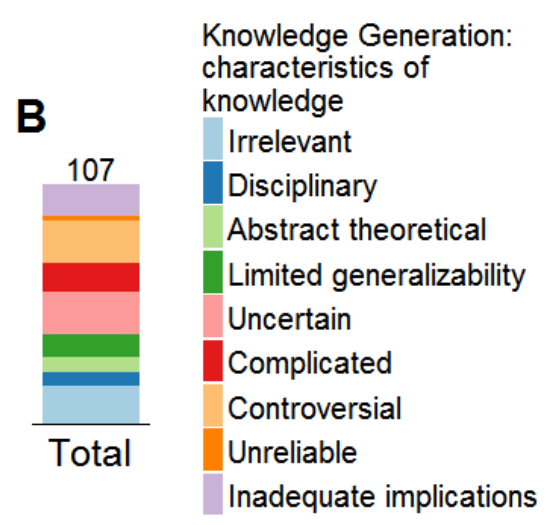

E

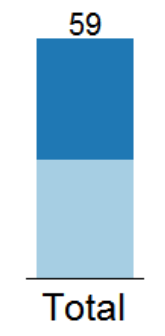

Knowledge Communication: reception by decision-makers Lack of access Difficulty in understanding

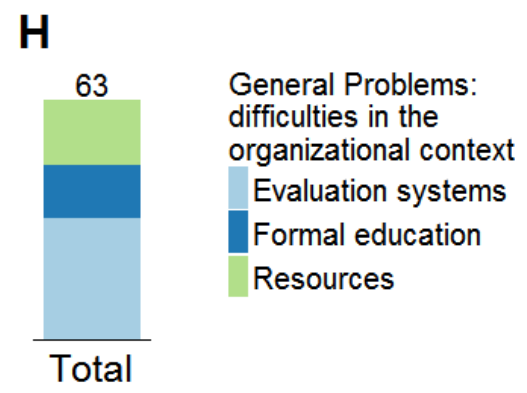

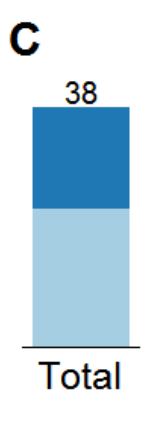

Knowledge Generation: knowledge gaps

Lack of knowledge

Lack of implications
$\mathbf{F}$

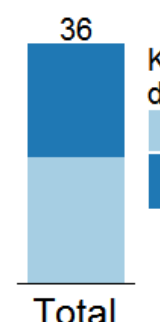

Knowledge use: disregarded Rejection by decision-makers Impediment by the organizational structure

Figure S10. Relative proportion of articles (excluding those that investigated empirically the opinions of scientists and/or decision-makers) including each lower-level category of perceived causes of the science-practice gap in Ecology and Conservation within third-level categories of the perspective "One knowledge". In knowledge generation: lowerlevel categories of "Flawed or inefficient research" (A), of "Characteristics of knowledge or implications" (B) and of "Knowledge gaps" (C). In knowledge communication: lower-level categories of "Problems in knowledge transfer by scientists" (D) and of "Problems in knowledge reception by decision-makers" (E). In knowledge use: lower-level categories of "Knowledge disregarded" (F). In feedback from practice: direct lower-level categories (G). In "General problems": lower level categories of "Difficulties associated with the organizational context" $(H)$ and of "Difficulties associated with models of science and science-practice linkages" (I). Because one article can include more than one category of perceived causes, the number above bars is greater than the total number of articles for each category. 
A

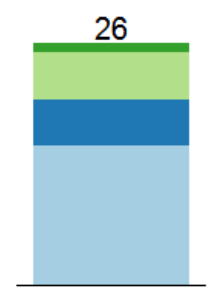

Total
Problems in Interactions: difficulties in the organizational context Evaluation systems Formal education

Resources

High turnover in practice
B

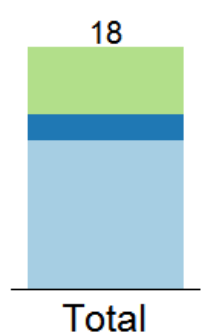

Problems in Interactions:

difficulties in models of science

Linear model

Model of emphasis on

scientific rigor quality

Model of emphasis on

objective and

impartial knowledge

Total

Figure S11. Relative proportion of articles (excluding those that investigated empirically the opinions of scientists and/or decision-makers) including each lower-level category of perceived causes of the science-practice gap in Ecology and Conservation within the third-level categories of the perspective "Two knowledges". In "Problems in interactions": lower-level categories of "Difficulties associated with the organizational context" (A) and of "Difficulties associated with the models of science and science-practice linkages" (B). Because one article can include more than one category of perceived causes, the number above bars is greater than the total number of articles for each category. 


\section{CHAPTER 2}

Revealing patterns of shared thinking on the science-practice interface in Ecology and Conservation

Diana B. Garcia, Carla Morsello, Charbel N. El-Hani, Renata Pardini

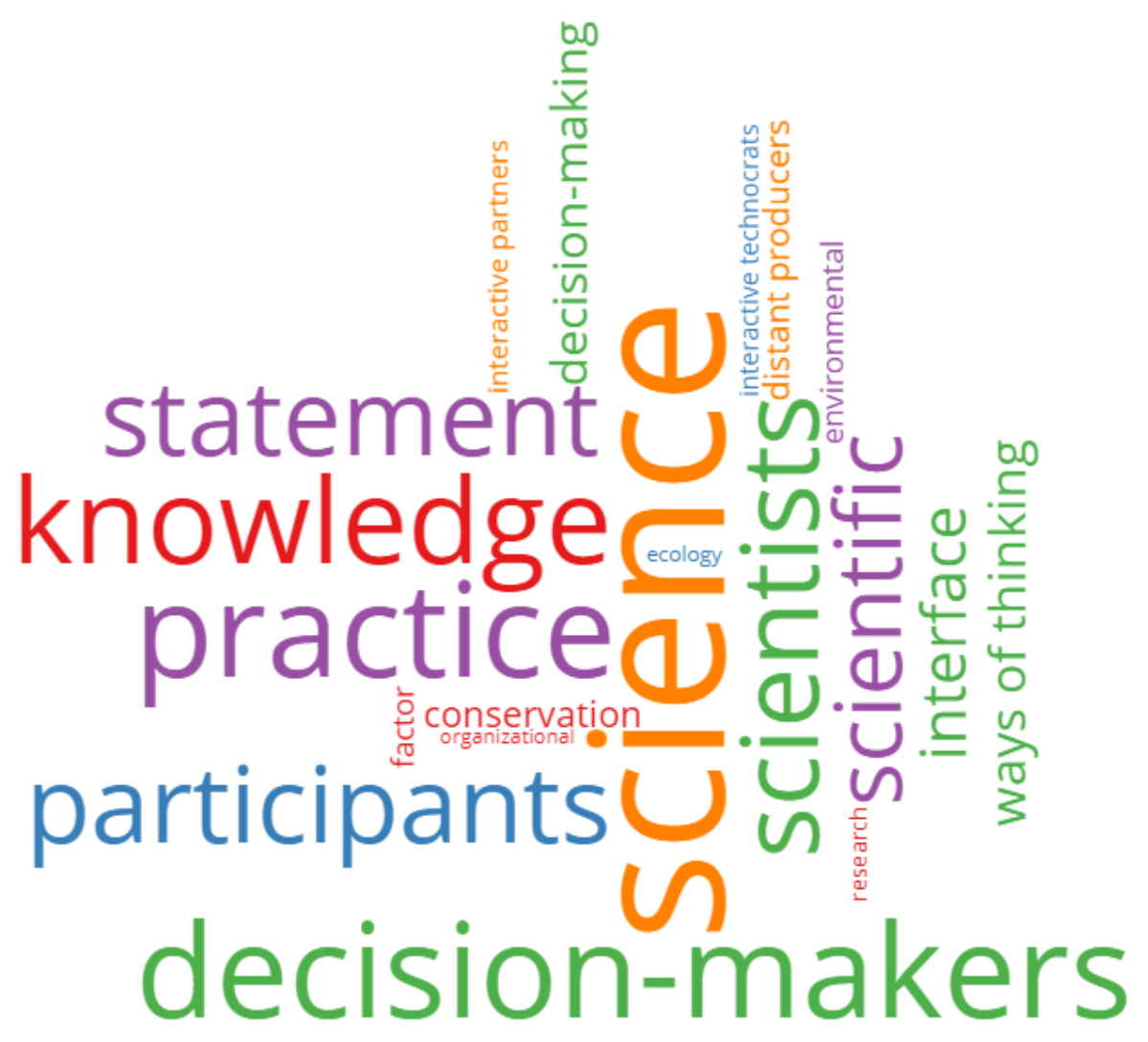




\section{ABSTRACT}

The science-practice interface in Ecology and Conservation is a contentious topic. While many have argued for the existence of a "science-practice gap" and called for "evidence-based conservation", others questioned these concepts for assuming linearity in science communication and neglecting other knowledges and the intricate processes of decision-making. Understanding and making explicit these divergent opinions is a key democratic strategy to deal with unequal power relations, challenge the hegemony of dominant models, and identify mechanisms to bridge science and practice that will receive support from different actors. We used Q-methodology to systematically assess the shared ways of thinking about the science-practice interface among scientists and decision-makers of a tropical developing nation with a growing science, where the role of science in environmental decision-making has received great attention. We asked 22 ecologists hired at Brazilian universities and decision-makers from the federal environmental agency to rank their agreement with 48 statements describing how the science-practice interface should be. Principal component analysis was used to identify groups of participants whose responses were similar, representing shared ways of thinking about the science-practice interface. The predominant viewpoint was shared among scientists and decision-makers who valued the integration of scientific and strategic knowledge to tackle environmental issues. The second was held mostly by decision-makers assigning great importance to science in decisionmaking and calling for more relevant research. The last was shared by scientists less willing to collaborate, seeing decision-makers as responsible for correctly interpreting science. All participants agreed actors and knowledges from both science and practice are important, but differed on the roles assigned to science, scientists or decisionmakers, the organizational structures considered more effective and the willingness to engage in collaborations. Our findings also suggest that cultural differences between scientists and decision-makers may be less relevant than the lack of organizational incentives as impediments to effective linkages between science and practice. Moreover, when establishing science-practice partnerships, it is critical to openly debate expected roles of scientists and decision-makers. Exploring and making diversity of opinions explicit in studies such as ours can help guiding such democratic strategies and may inspire future studies in regions and countries other than Brazil. 


\section{KEYWORDS}

Research-implementation gap; knowing-doing gap; environmental policy; environmental management; policy-making; Q-sorting; operant subjectivity; personal opinions; social constructionism.

\section{INTRODUCTION}

The science-practice interface - the relationship between science and decisionmaking across different policy and management contexts - is a contentious topic. In the political sciences, theoretical conceptualizations of decision-making processes and of the role of science in decision-making range from emphasizing science as the sole provider of relevant information to decision-makers to assigning a minor role to scientific knowledge in a complex and unpredictable political process (reviewed in Albaek, 1995; Neilson, 2001; Nutley, Walter, \& Davies, 2007). In Ecology and Conservation, the science-practice interface has also been the focus of intense debate. Ecologists and conservation scientists have been criticized for not effectively helping to solve aggravating environmental problems (Whitten, Holmes, \& MacKinnon, 2001) and practitioners for not using scientific knowledge to support their decisions (Pullin et al., 2004). Many authors have then argued for the existence of a "science-practice gap" (e.g, Knight et al., 2008; Esler et al., 2010; Barmuta, Linke, \& Turak, 2011).

Distinct conceptualizations of the relationship between ecological and conservation science and practice have been proposed, from linear to more integrative models of science communication and knowledge production (Roux et al., 2006; Pregernig, 2014; Chapter 1). Indeed, recent controversies in the literature suggest diverse understandings of how the science-practice interface should ideally be or of which are the best strategies to link science and practice. To bridge the science-practice gap, several ecologists and conservation scientists have called for an evidence-based approach to systematically collate and disseminate scientific evidence (e.g, Pullin \& Knight, 2003; Sutherland \& Pullin, 2004; Dicks, Walsh, \& Sutherland, 2014). The concepts of the "science-practice gap" and of "evidence-based conservation" were in turn criticized for being based on a linear, unidirectional linkage between science and practice, neglecting the relevance of other types of knowledge and the intricate processes of decision-making (Adams \& Sandbrook, 2013; Toomey, Knight, \& Barlow, 2016). To overcome this linearity in science communication, some have 
emphasized the importance of social learning and knowledge coproduction among scientists and decision-makers (Shackleton, Cundill, \& Knight, 2009; Hegger et al., 2012; Pardini et al., 2013).

These controversies suggest ecologists and conservation scientists hold diverse opinions on the science-practice interface. Nonetheless, the debate on the relationship between science and practice has largely been conducted from an academic perspective, with few studies considering the opinion of decision-makers (e.g, Mattson et al., 2006; White, Corley, \& White, 2008; Young \& Van Aarde, 2011; Neff \& Larson, 2014). The ways of thinking of decision-makers may diverge from those of scientists (e.g, Castillo et al., 2005) because they typically work in distinct contexts and come from different cultures, holding diverse values, languages, beliefs and working routines (Caplan, 1979; Neilson, 2001), and use distinctive strategies to communicate across the science-practice interface (Roux et al., 2006). Moreover, ways of thinking on the subject should vary not only among distinct actors, but also across institutions, regions or countries, given the variety of values, and cultural, social, and political contexts.

Understanding this diversity of opinions is important to develop productive science-practice linkages (e.g, White et al., 2008) for at least three reasons. First, making explicit and discussing divergent opinions represent a key democratic strategy to deal with unequal power relations (Peterson, Peterson, \& Peterson, 2005), which can frequently arise between scientists and other actors when scientific knowledge is used in decision-making (Collingridge \& Reeve, 1986; Wynne, 1996). Second, by challenging hegemony and dominant models, focusing on diversity can also increase our capacity to find effective solutions to link science and practice (Carpenter et al., 2009a). Finally, understanding the viewpoints on the science-practice interface can assist identifying which mechanisms to foster a more productive use of science in decision-making will potentially receive support and from whom this support will come (Barry \& Proops, 1999).

Understanding ways of thinking about the science-practice interface can be even more important in tropical developing nations, where the science-practice gap is a more pressing problem (Pardini et al., 2013). While most of the global terrestrial, mangrove and reef biodiversity is found in the tropics, deep social, political and economic challenges threaten socio-ecological systems in this region (State of the Tropics, 2014). Natural resources are being increasingly exploited to sustain rapid population growth, 
economic development and urbanization rates (State of the Tropics, 2014), and poverty, warfare and poor governance across many countries imperil implementation of policies and legislation to manage or conserve biodiversity (Hanson et al., 2009; State of the Tropics, 2014; World Bank, 2017). Nonetheless, increased investment in research and higher education during the past decades (State of the Tropics, 2014) has created opportunities to deal with these challenges by fostering better structured and qualified research institutes, government bodies and non-government organizations (Pardini et al., 2013). Consequently, awareness of the importance of considering the challenges and opportunities of tropical developing nations for achieving global sustainable development goals has increased worldwide (Harding, 2016).

In this study, we aim to understand how scientists and decision-makers in a tropical developing nation think about the science-practice interface in Ecology and Conservation. Specifically, we aim to describe the different viewpoints of scientists and decision-makers and identify possible points of consensus or conflict regarding how the relationship between science and practice should ideally be. Detecting disagreements helps us to think how to deal with these conflicts, while points of consensus can reveal paths for more effective dialogue and interaction. We focus on Brazil as an example of a tropical developing nation with a growing science (Adams, Pendlebury, \& Stembridge, 2013; van Noorden, 2014), and where the role of science in environmental decision-making has received great attention given recent changes in crucial environmental policies (Ferreira et al., 2014; Loyola, 2014; Fearnside, 2016; Tollefson, 2016; Azevedo-Santos et al., 2017).

\section{MATERIAL AND METHODS}

To identify ways of thinking about the science-practice interface, we used Qmethodology - developed in Psychology (Stephenson, 1935) as a holistic approach to study subjectivity (McKeown \& Thomas, 1998). Participants are asked to give their opinion regarding several statements by evaluating each of them in relation to all others, producing a distribution of statements across a ranking scale of agreement (called a Q-sort) (Table 1). Instead of looking separately at the agreement with individual statements, the whole Q-sort is analyzed, allowing a holistic view of participants' way of thinking. Q-sorts are correlated and subjected to factor analysis (with participants as variables) to identify groups of responses highly correlated to each 
other, representing shared ways of thinking. The method is particularly suited for studying controversial themes, as it unravels the complex nature of people's viewpoints (Barry \& Proops, 1999). It has become popular in several disciplines other than Psychology (Watts \& Stenner, 2012), being increasingly used to untangle social aspects of conservation, environmental and sustainability issues (e.g, Barry \& Proops, 1999; Webler, Tuler, \& Krueger, 2001; Mattson et al., 2006; Sandbrook et al., 2011; Neff \& Larson, 2014; Cairns, Sallu, \& Goodman, 2014; Holmes, Sandbrook, \& Fisher, 2016).

\section{Development of the set of statements (Q-set)}

To allow participants to freely express their viewpoints, the set of statements (called the Q-set) must be representative of the breadth of existent ideas regarding the research topic (known as "concourse"). Using a structured approach to assure representativeness, we broke down the concourse into different topics or categories and generated statements to represent each category (Watts \& Stenner, 2012). We based our structure on a process-based framework that identifies distinct conceptions or perspectives on the science-practice interface in Ecology and Conservation, developed by cutting and sorting sentences on the causes of the science-practice gap from the ecological and conservation literature (Chapter 1). The framework identifies three main conceptions that account for different processes, actors and knowledges in the sciencepractice interface (Fig. 1). The first conception establishes a linear flow of knowledge from science (or scientists) to practice (or decision-makers), through the processes of knowledge generation, communication, use and feedback, emphasizing a primacy of scientific knowledge (Fig. 1A). The second conception highlights a bidirectional flow of knowledge between science (or scientists) and practice (or decision-makers), through the interactive process of knowledge integration, thus recognizing the relevance of decision-makers' knowledge (Fig. 1B). Lastly, the third conception emphasizes only the involvement of scientists in the science-practice interface, who should generate and apply scientific knowledge in practice (Fig. 1C). 
Table 1. Example of a Q-sort with the instructions for sorting the 48 statements used to identify ways of thinking about the science-practice interface in Ecology and Conservation.

\section{Question}

How should the encounter, communication and/or interaction between people, organizations and knowledges involved in science and practice be to improve decision-making?

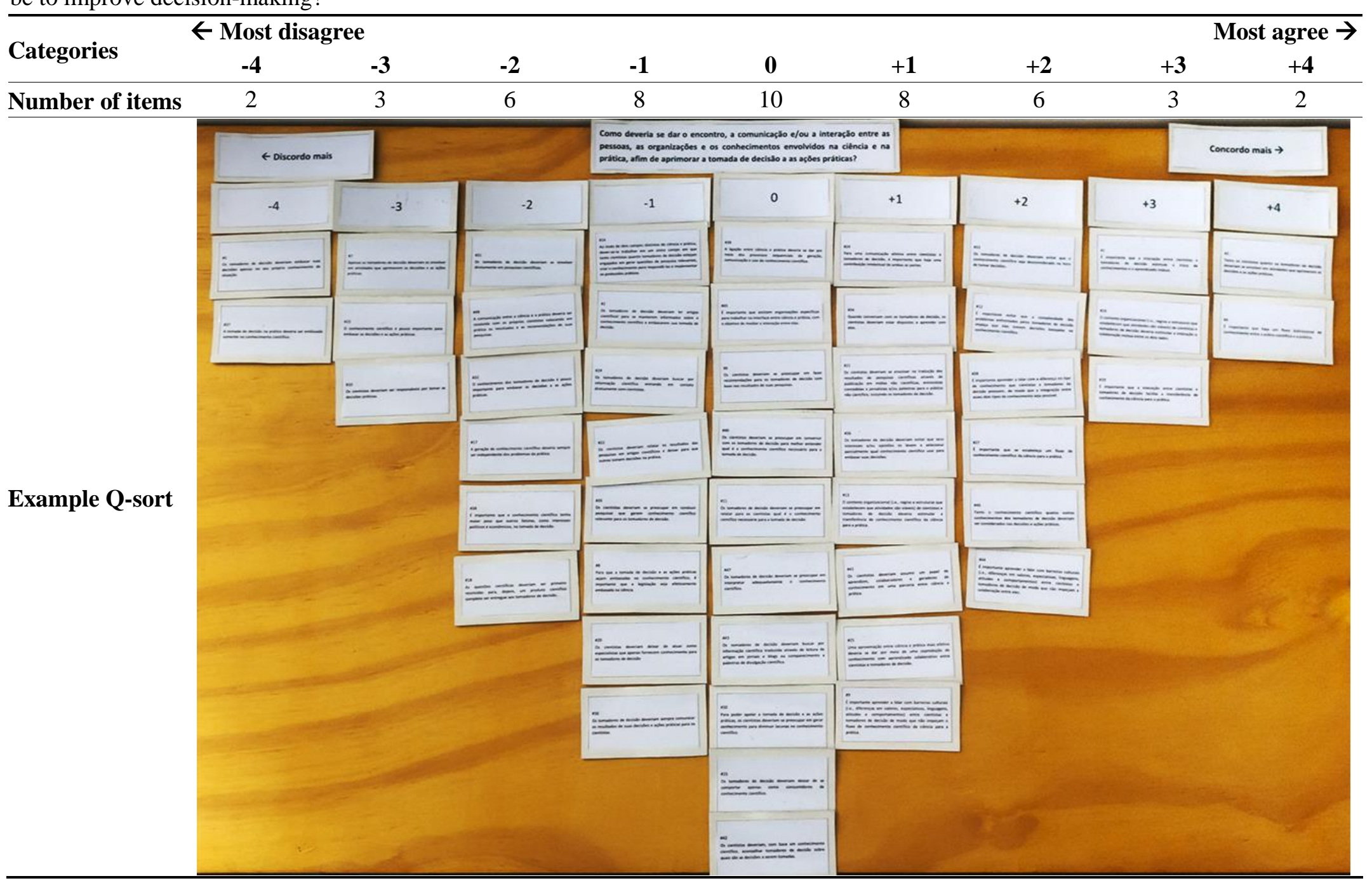


For each of these three conceptions, we created statements describing the processes, knowledges and actors supposed to be involved in the science-practice interface, and the ways science and practice were supposed to be linked (e.g, activities that scientists, decision-makers or organizations should engage in, and/or promote) (Appendix S1). To complement this list of statements and check if any important considerations were missing from our Q-set, we searched for additional suitable statements in relevant articles from the ecological and conservation literature and consulted two decision-makers with vast experience in bridging science and practice (Appendix S1). Additional statements from the literature were translated to Portuguese and edited to match the style of the statements we created. The final Q-set had 48 statements (Appendix S1), within the range of 30-60 statements recommended for Qstudies (Watts \& Stenner, 2012). We then tested the Q-set with five scientists and two decision-makers to fine-tune wording and interview procedures.
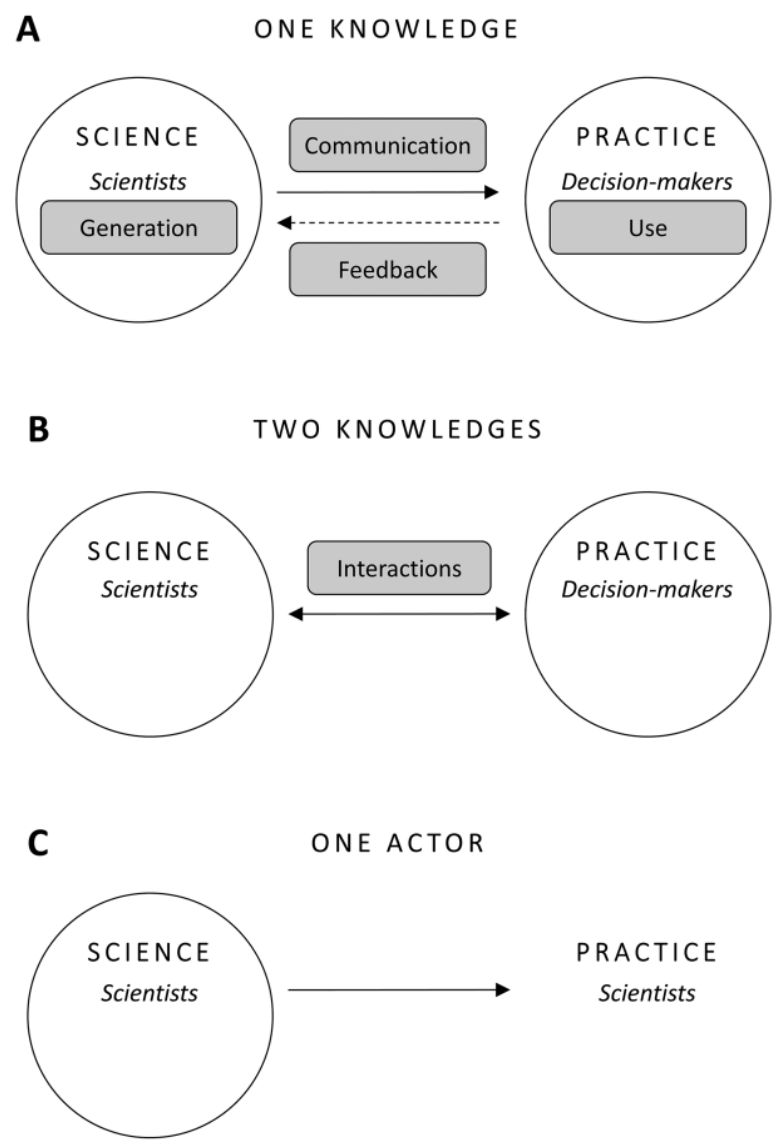

Figure 1. Schematic representation of the three conceptions on the processes, actors and knowledges involved in the science-practice interface in Ecology and Conservation. Text in italic represents recognized actors, gray boxes represent the processes. Reproduced and modified from chapter 1. 


\section{Selection of participants (P-set)}

Our pool of scientists was composed of prominent active Brazilian researchers in Ecology or Conservation Science that were advisors within graduate programs (included in the general area of Biodiversity) with a "high standard of excellence", according to the evaluation of the National System for Graduate Studies (CAPES, 2015). Our pool of decision-makers was composed of analysts working for at least 5 years in the federal environmental-enforcement agency (Brazilian Institute of Environment and Renewable Natural Resources - IBAMA), who rely on knowledge from Ecology and Conservation Science on a regular basis. Their tasks spanned environmental impact assessments, regulation of sustainable use of natural resources and environmental surveillance. Although these analysts are not involved in defining general environmental policies or laws, they are key in environmental decision-making in Brazil because they are responsible for the technical analyses of a range of different policies, thus deciding how these policies are implemented.

Because we aimed to identify the diversity of viewpoints on the science-practice interface rather than to generalize findings to a wider population, participants were chosen strategically from our pools using stratified purposeful sampling to represent relevant and varied ways of thinking (Watts \& Stenner, 2012; Patton, 2014). First, due to the marked variation in environmental, socio-economic and cultural contexts across Brazil, we selected at least two scientists and two decision-makers from each of the five Brazilian regions. Second, assuming the degree of contact that scientists have with practice and decision-makers have with science can influence how they view the science-practice interface, we searched, within each region, for at least one scientist and one decision-maker that commonly interacted with decision-making and science, respectively, and one that seldom did (Appendix S2). To reduce travels costs, most scientists were selected among speakers of the most prestigious national congress of Ecology (Appendix S2). In total, we interviewed 11 scientists and 11 decision-makers (Table 2), during October and November 2016. Such small sample sizes are characteristic of Q-methodology studies because participants become variables in the analysis, being generally advisable to have maximum half as many participants than statements (i.e., the observations) (Watts \& Stenner, 2012). 
Table 2. Information on the 22 participants of the Q-methodology study to identify shared ways of thinking about the science-practice interface among Brazilian scientists and decisionmakers.

\begin{tabular}{lccc}
\hline & Scientists & $\begin{array}{c}\text { Decision- } \\
\text { makers }\end{array}$ & Total \\
\hline Total & 11 & 11 & 22 \\
\hline Sex & 7 & 4 & 11 \\
Male & 4 & 7 & 11 \\
Female & & & \\
Region of Brazil & 2 & 2 & 4 \\
South & 2 & 3 & 5 \\
Southwest & 3 & 2 & 5 \\
Center-West & 2 & 2 & 4 \\
Northeast & 2 & 2 & 4 \\
North & 11 & 11 & 22 \\
With Bachelor degree* & 11 & 7 & 18 \\
Biology & 0 & 1 & 1 \\
Ecology & 1 & 2 & 3 \\
Engineering & 0 & 2 & 2 \\
Law & 1 & 0 & 1 \\
Pharmacy & 0 & 1 & 1 \\
Economy & 8 & 7 & 17 \\
With Master degree & 4 & 3 & 7 \\
Ecology & 1 & 2 & 3 \\
Zoology & 1 & 0 & 1 \\
Wildlife management & 2 & 0 & 2 \\
Plant physiology & 0 & 1 & 1 \\
Forest resources & 0 & 1 & 1 \\
Biological oceanography & 11 & 2 & 13 \\
With PhD degree & 8 & 0 & 8 \\
Ecology & 2 & 0 & 2 \\
Zoology & 1 & 0 & 1 \\
Botany & 0 & 1 & 1 \\
Biological oceanography & 0 & 1 & 1 \\
Environmental law & & & \\
*Several participants had two or more bachelor degrees, making the sum \\
greater than the total number of participants. & & \\
& & & \\
\hline
\end{tabular}

\section{Supporting variables}

To assist in the interpretation of the distinct ways of thinking on the sciencepractice interface, we applied a self-administered questionnaire to participants before the Q-sorting activities. The questionnaire encompassed: (1) educational and professional background, (2) attitudes towards positivism and use of scientific knowledge, and (3) engagement in activities related to either science (for decisionmakers) or practice (for scientists) (Appendix S3). To quantify attitudes towards positivism, we used a scale measuring the degree to which participants accepted that scientific method is neutral, unbiased and independent of value judgements, providing 
objective and accurate information about the world and thus being the only way to acquire valid knowledge (developed by Steel et al., 2004).

\section{Data collection}

In-person interviews were conducted individually with each participant by the same researcher. We first obtained from the participant a written voluntary and informed consent to participate in the study and asked him/her to read the definitions of the terms "science", "scientists", "practice" "decision-makers" and "science-practice interface" (Appendix S4), clarifying any doubts regarding these terms. Next, we asked the participant to fill out the self-administered questionnaire to collect supporting information (Appendix S3). The participant was then asked to sort the Q-set into a 9point ranking scale ranging from highest disagreement (-4) to highest agreement (+4) according to how he/she believed the science-practice interface should ideally be (Table 1). Statements were provided in random order, on separated and randomly numbered cards. The participant first read all statements, dividing them into three provisional categories (agreement, disagreement and neutral) and then fine sorted statements into the ranking scale, beginning with the extreme categories. The resulting distribution of statements per ranking category is the Q-sort.

Throughout the sorting process, participants were asked to explain their choice for the statements with which they most strongly agreed or disagreed (categories -4, $3,-2$ and $+2,+3,+4)$. These explanations were recorded in audio to support subsequent interpretations. All stages of data collection were conducted in Portuguese. Quotations from recorded audios were translated by the authors into English for publication only, being kept as literal as possible, except when minor modifications were necessary to assure understanding. Original transcripts in Portuguese of quotations mentioned in the Results section are presented in Appendix S5. Questionnaires and interview procedures were evaluated and approved by the Research Ethics Committee from the Biosciences Institute of the University of São Paulo (CAAE 58664616.2.0000.5464).

\section{Data analysis}

We correlated participants' Q-sorts (Pearson's $r$ ) and performed principal components analysis on the participant-by-participant correlation matrix to extract components, which represent shared thinking among participants (or factors, in Q- 
method terminology). To ensure these factors were aligned with most predominant ways of thinking about the science-practice interface, we performed varimax rotation, a mathematical solution in which each participant has a high loading in one of the factors (Watts \& Stenner, 2012). Based on criteria from Watts \& Stenner (2012), the first three factors were selected for rotation (Appendix S6).

Each rotated factor represents a combination of participants that have produced similar Q-sorts, suggesting shared ways of thinking about the science-practice interface. To gain access to these shared ways of thinking, we then created an idealtypical Q-sort for each factor by combining the responses of participants who were highly correlated to only that factor (i.e, the defining Q-sorts as in Zabala, 2014). To combine defining Q-sorts, we used a weighted sum, where participants whose responses were more similar to the factor contributed more to the ideal Q-sort (Watts \& Stenner, 2012). By normalizing the summed values for each statement and converting them to integer, each statement received a value from -4 to +4 , satisfying the original forced distribution (Table 1). As a result, an ideal-typical Q-sort of the factor - the factor array - was produced (Table 3), which represents how the way of thinking about the science-practice interface captured by the factor views each statement.

We also calculated the level of disagreement between the different ways of thinking regarding the ranking of each statement, as well as how strongly each statement was ranked across the different ways of thinking (i.e, the salience of the statement). Based on procedures developed by Neff \& Larson (2014), both disagreement and salience were calculated using the normalized values of each statement in all factor arrays: the level of disagreement was estimated using the standard deviation of these values, and salience, using the mean of the absolute values. High standard deviations represent high disagreement across ways of thinking and low standard deviations represent high agreement, or consensus. Absolute values were used for salience because both high positive and high negative values indicate strong opinion towards the statement. All calculations were computed in the $\mathrm{R}$ environment $(\mathrm{R}$ Development Core Team, 2008), using the qmethod package (Zabala, 2014).

To interpret each factor (shared way of thinking), we first inspected each factor array as a whole, but paying special attention to the most salient statements with highest agreement or disagreement. We also examined the recorded explanations of 
participants who loaded high on the factor. Lastly, we used the information collected via self-administered questionnaire (Appendix S3) to look for patterns in the responses of participants associated to each factor. We then created a narrative for each factor that represents our interpretation of the different ways of thinking about the sciencepractice interface. Based on these ways of thinking, we gave a symbolic name to the group of participants associated to each of them.

\section{RESULTS}

In general, attitudes towards the use of ecological knowledge in environmental decision-making were equally favorable between scientists and decision-makers, while decision-makers were more receptive to positivist beliefs than scientists (Appendix S7). Decision makers infrequently published papers in scientific journals, participated directly in scientific research or counseled scientists regarding relevant research topics (2-4 participants had performed these activities in the last 5 years), but commonly read scientific articles and searched for translated scientific information (all decisionmakers had performed these activities) (Appendix S7). Scientists seldom participated directly in decision-making (4 participants had performed this activity in the last 5 years), but often translated research results for non-scientific audiences (all scientists had performed this activity) (Appendix S7).

We identified three factors representing different ways of thinking about the science-practice interface in Ecology and Conservation (Table 3), explaining 69.1\% of the total variance of the $22 \mathrm{Q}$-sorts. Three participants presented mixed opinions, with Q-sorts weakly correlated to all three factors, and were excluded from the calculations of factor arrays (Appendix S8). 
Table 3. Factor arrays of the three ways of thinking about the science-practice interface in Ecology and Conservation (F1=Interactive Partners, F2=Interactive Technocrats, F3=Distant Producers). Red indicates highest discordance and green, highest concordance of each way of thinking with each statement. Salience (Sal) and level of disagreement (Dis) for statements are shown as bars. Statements are ordered from lowest to highest disagreement across factors. Highly salient statements (salience above-average) are marked: in bold when they presented low disagreement (below average), and in grey background when they presented high disagreement (above average).

\# Statement text

1 The knowledge of decision-makers is of little importance to support decision-making.

2 Scientists should, based on scientific knowledge, advice decision-makers on which decisions to make.

3 Learning to deal with cultural barriers (i.e., differences in values, expectations, languages, attitudes and behaviours) among scientists and decision-makers is important to establish collaborations among them.

4 An intellectual contribution from both parties is important for an effective communication between scientists and decision-makers.

5 Decision-making should be based solely on scientific knowledge.

6 Scientists should stop acting as experts who only provide knowledge for decision-makers.

The organizational context (i.e., rules and structures establishing which activities are viable) of scientists and decision-makers should promote the transference of scientific knowledge from science to practice.

8 Decision-makers should be directly involved in scientific research.

9 Decision-makers should always communicate the results of their decisions and actions to scientists.

10 Scientific knowledge is of little importance to support decision-making.

11 Decision-makers should stop acting only as consumers of scientific knowledge.

12 The generation of scientific knowledge should always be independent of the problems of practice.

13 When talking to decision-makers, scientists should be willing to learn from them

14 Learning to deal with cultural barriers (i.e., differences in values, expectations, languages, attitudes and behaviours) among scientists and decision-makers is important to establish the flow of scientific knowledge from science to practice.

15 Scientific questions should first be resolved so that afterwards a complete scientific product can be delivered to decision-makers.

16 Science and practice will be more effectively brought together through knowledge coproduction with collaborative learning among scientists and decision-makers.

17 Decision-makers should search for translated scientific information by reading articles in newspapers and blogs or attending scientific divulgation talks.

18 Learning to deal with differences in the type of knowledge of scientists and decision-makers is important to allow for integration among these two types of knowledge.

19 Scientists should worry about making recommendations for decision-makers based on their research results.

20 Scientists should report their research results in scientific articles and let others make decisions in practice.

21 Decision-makers should worry about reporting back to scientists what scientific knowledge is needed for decision-making.

22 Establishing a flow of knowledge from science to practice is important.
F1 F2 F3 Sal. Dis.

\begin{tabular}{lll|l|l}
-2 & -2 & -3 & 1.48 & 0.06
\end{tabular}

\begin{tabular}{lll|l|l|}
0 & 1 & 0 & 0.31 & 0.08
\end{tabular}

\begin{tabular}{lll|l|l}
2 & 2 & 2 & 1.04 & 0.11
\end{tabular}

\begin{tabular}{lll|l|l}
1 & 1 & 1 & 0.47 & 0.11
\end{tabular}

\begin{tabular}{lll|l|l|}
-4 & -3 & -3 & 1.85 & 0.14 \\
\hline
\end{tabular}

\begin{tabular}{llll|l|l}
-1 & -1 & 0 & 0.09 & 0.14
\end{tabular}

\begin{tabular}{ll|l|l|l|}
1 & 1 & 2 & 0.70 & 0.19
\end{tabular}

\begin{tabular}{ll|l|l|l}
-2 & -2 & -1 & 0.81 & 0.21 \\
\hline
\end{tabular}

\begin{tabular}{lll|l|l|}
-1 & -1 & -1 & 0.36 & 0.23 \\
\hline
\end{tabular}

\begin{tabular}{lll|l|l}
-3 & -3 & -3 & 1.71 & 0.24 \\
\hline
\end{tabular}

\begin{tabular}{l|ll|l|l|}
0 & -1 & -1 & 0.21 & 0.24 \\
\hline
\end{tabular}

\begin{tabular}{lll|l|l|}
-2 & -3 & -3 & 1.61 & 0.28
\end{tabular}

\begin{tabular}{l|l|l|l|l|}
1 & 0 & 1 & 0.49 & 0.28
\end{tabular}

\begin{tabular}{l|ll|l|l|}
1 & 0 & 0 & 0.35 & 0.28 \\
\hline
\end{tabular}

\begin{tabular}{ll|l|l|l}
-2 & -2 & -4 & 1.54 & 0.29 \\
\hline
\end{tabular}

\begin{tabular}{l|l|l|l|l|}
1 & 0 & -1 & 0.28 & 0.29
\end{tabular}

\begin{tabular}{lll|l|l|}
0 & 0 & -1 & 0.24 & 0.30
\end{tabular}

\begin{tabular}{lll|l|l|l}
2 & 1 & 2 & 0.85 & 0.31 \\
\hline
\end{tabular}

\begin{tabular}{l|ll|l|l|}
0 & -1 & -1 & 0.24 & 0.31 \\
\hline
\end{tabular}

\begin{tabular}{l|ll|l|l}
-1 & -2 & -2 & 0.87 & 0.32 \\
\hline
\end{tabular}

\begin{tabular}{lll|l|l|}
0 & 0 & 1 & 0.32 & 0.33 \\
\hline
\end{tabular}

\begin{tabular}{l|ll|l|l}
2 & 0 & 0 & 0.36 & 0.35 \\
\hline
\end{tabular} 
Table 3. Continued.

\# Statement text

F1 F2 F3 Sal. Dis.

23 Decision-makers should base their decisions only on their own knowledge of the situation.

24 Only decision-makers should be involved in activities to improve decisions-making.

25 Scientists should be responsible for making decisions in practice.

26 Decision-makers should read scientific articles to stay informed on scientific knowledge and to support their decisions.

27 Decision-makers should worry about correctly interpreting scientific knowledge.

28 Legislation being effectively grounded on science is important to assure decision-making will be supported by scientific knowledge.

29 Decision-makers should search for scientific information by contacting scientists directly.

30 The link between science and practice should occur by sequential processes of generation, communication and use of scientific knowledge.

\begin{tabular}{lll|l|l|}
-4 & -4 & -2 & 1.84 & 0.39 \\
\hline
\end{tabular}

\begin{tabular}{l|l|l|l|l|}
-3 & -4 & -2 & 1.53 & 0.39
\end{tabular}

\begin{tabular}{l|l|l|l|l|}
-3 & -2 & -2 & 1.50 & 0.40 \\
\hline
\end{tabular}

\begin{tabular}{lll|l|l}
-1 & 1 & 0 & 0.40 & 0.43
\end{tabular}

\begin{tabular}{lll|l|l|l|l}
0 & 1 & 2 & 0.59 & 0.46
\end{tabular}

\begin{tabular}{lll|l|l|l|l|l|l|l}
-1 & 1 & 2 & 0.49 & 0.47
\end{tabular}

\begin{tabular}{lll|l|l|l|l|l}
-1 & -1 & 1 & 0.33 & 0.47
\end{tabular}

\begin{tabular}{lll|l|l|l}
0 & 0 & -1 & 0.31 & 0.47
\end{tabular}

31 Avoiding that the complexity of problems faced by decision-makers prevents them from making decisions based on scientific knowledge is important.

\begin{tabular}{ll|l|l|l}
2 & 2 & 4 & 1.12 & 0.48
\end{tabular}

32 Scientists should get involved in translating scientific research results by publishing in non-scientific medias, giving interviews to journalists and/or giving talks for non-scientific audiences, such as

decision-makers.

33 Both scientific knowledge and other knowledges from decision-makers should be considered in decision-making.

34 Scientists should take on the role of learners, collaborators and knowledge generators in a partnership between science and practice.

35 The communication between science and practice should be resolved with scientists themselves putting into practice the results and recommendations of their research.

36 Establishing a bidirectional flow of knowledge between scientific and practical spheres is important.

37 The organizational context (i.e., rules and structures establishing which activities are viable) of scientists and decision-makers should promote interactions and mutual collaborations among them

38 Decision-makers should avoid being influenced by their interests and/or opinions to partially select which scientific knowledge to use to support their decisions.

39 Scientists should worry about talking to decision-makers to better understand which scientific knowledge is necessary for decision-making.

40 Interactions between scientists and decision-makers should facilitate the transference of knowledge from science to practice.

41 To support decision-making, scientists should worry about generating knowledge to fill gaps in scientific knowledge.

42 Interactions between scientists and decision-makers should promote knowledge exchange and mutual learning.

43 Both scientists and decision-makers should be involved in activities to improve decision-making.

44 Decision-makers should avoid disregarding scientific knowledge when making decisions.

45 Specific organizations working in the interface between science and practice, with the specific goal of mediating interactions, should be established.

46 Scientists should be concerned with conducting research that generates scientific knowledge that is relevant for decision-makers.

47 Scientific knowledge having more weight than other factors, such as political and economic interests, in decision-making is important.

48 Instead of two distinct fields of science and practice, there should be a single field with scientists and decision-makers engaged in generating relevant research questions, creating knowledge to answer them and implementing practical protocols. 
As the three factor arrays were moderately correlated with each other $(0.57<\mathrm{r}<0.62)$, indicating several areas of agreement between ways of thinking, we begin by describing the similarities among them. Then, in the narratives describing each way of thinking about the science-practice interface, we emphasize their differences.

Of the 12 statements identified as highly salient (salience above average) and with high agreement across factors (standard deviation of normalized values below average), 10 were negatively ranked in all factors (Fig. 2A). Participants across all ways of thinking considered highly undesirable that decision-making be based solely on one type of knowledge - either scientific (Statement 5) or any other type of knowledge from decisionmakers (Statement 23). No knowledge type was considered irrelevant to support decisionmaking (Statements 1 and 10). Correspondingly, participants associated with all viewpoints contested the idea of science being completely independent of practice (Statement 12), with scientists only publishing their work in scientific journals (Statement 20) or decision-makers working alone to improve decision-making (Statement 24). Thus, there was general agreement that both scientists and decision-makers are relevant actors in the science-practice interface. However, there was also consensus on a differentiated role for these actors due to high rejection of ideas that scientists should act as decisionmakers (Statement 25) or decision-makers should act more directly as researchers (Statement 8). Finally, the two statements ranked positively in all factors indicate the need to deal with differences in types of knowledge, values, expectations, languages, attitudes and behaviors between scientists and decision-makers to make collaborations more effective (Statements 18 and 3, Fig. 2A).

In contrast to the consensus statements, which were mostly negatively ranked (Fig. 2A), most statements with high disagreements across ways of thinking were ranked in either positive or neutral categories (Fig. 2B). Thus, although participants associated to each way of thinking agreed on how they believed the science-practice interface should not be, they differed on the aspects they considered more relevant to guide an ideal relationship between science and practice. These differences are emphasized below. 


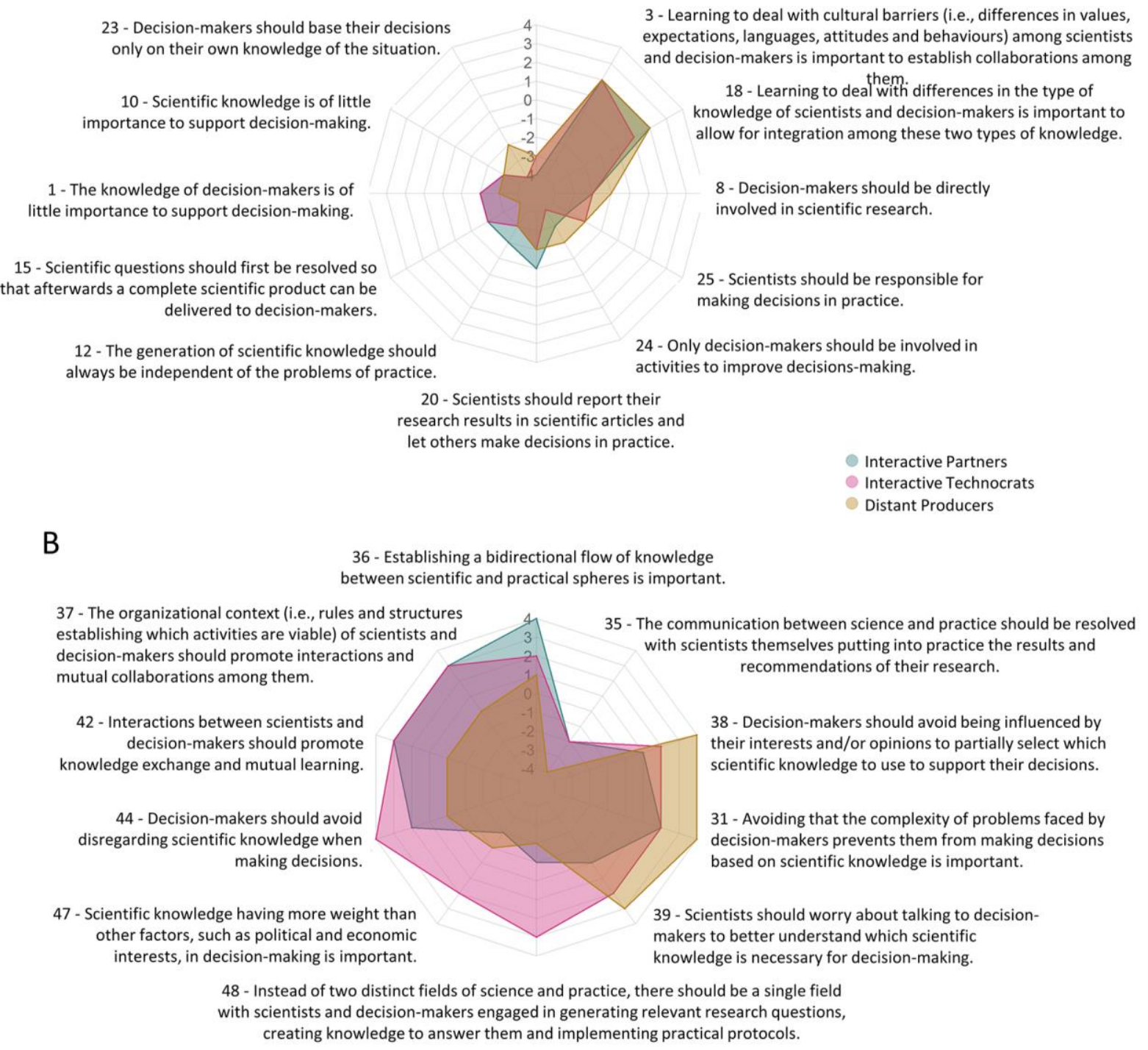

Figure 2. Consensus (A) and disagreements (B) across the three ways of thinking on the sciencepractice interface in Ecology and Conservation (Interactive Partners, Interactive Technocrats and Distant Producers) according to the most salient statements. Rankings are ordered from center (4) to exterior $(+4)$ of the circle.

\section{Participants associated with factor 1: Interactive Partners}

The Interactive Partners were both scientists and decision-makers who argued the science-practice interface should ideally be a space for collective creation of solutions for the problems faced by decision-makers. They were distinguished from other participants by recognizing as highly important the establishment of bidirectional knowledge flows with collaborative partnerships, mutual learning and coproduction of knowledge between scientists and decision-makers (Statements $36:+4,42:+3,16:+1$ ). One participant stated "the interaction should always be bidirectional, with knowledge generated in academia 
and the knowledge decision-makers bring from their experience being considered with the same weight. I believe the solution [...] should be the result of integration and interaction between these two knowledge types". This group of participants agreed more strongly than participants in the other groups with statements describing, in the same phrase, the importance of considering actors and knowledges from both science and practice (Statements 43: $+4,33:+2$ ). Thus, they presented themselves as possible partners in these collaborative interactions.

From this viewpoint, on the one hand, scientists have much to learn from decisionmakers about non-scientific issues, such as what is viable in terms of administrative or political restrictions. One participant explained that "as a scientist interacting with decision-makers, I am completely willing to listen and try to understand the strategic component of decisions [...] For me, as a biologist, it is very difficult to be aware of all the subtleties of the strategic game of politics". On the other hand, decision-makers can learn from scientists how scientific knowledge can help them to make informed decisions. For the Interactive Partners, the more both sides learn from each other and exchange knowledge, the more effective and realistic the solutions to the problems faced by decision-makers will be: "when they [scientists and decision-makers] have to work together, they put themselves in each other's shoes and, eventually, the decision-making and the collective enterprise are more realistic". Although these participants were more concerned than others with establishing a flow of knowledge from science to practice (Statements 40: $+3,22:+2$ ), this transference was considered important only for providing a starting point for collaborations. When explaining their agreement with these two statements, almost all participants in this group stressed the flow of knowledge is important, but it needs to go both ways. Several also explicitly argued that a unidirectional flow of knowledge from science to practice would be undesirable.

Because scientific knowledge should be integrated with strategic knowledge of decision-makers, the Interactive Partners reasoned science should not necessarily have more weight than other factors (e.g, political interests) in final decisions (Statement 47: 2). This view was shared with participants associated to the third way of thinking, but not with the second (Fig. 3). One participant explained scientific knowledge "will politically dispute the decision, because decisions will be influenced by several factors and scientific knowledge will have to dispute with them. Eventually, scientific knowledge that is relevant and of quality will have more weight, but eventually not". For the Interactive 
Partners, one important point was to assure scientific knowledge can at least enter decision-making as one aspect to be considered (Statement 44: +2 ). This is exemplified in the following passage by one participant: "I fully understand there is much more at stake than scientific knowledge, but it would be great if this [scientific evidence] could be set on the table as one of the cards to be played". For the Interactive Partners, the great complexity of problems faced by decision-makers, encompassing different actors and interests, should not serve as a pretext to ignore scientific considerations in decisionmaking (Statement 31: +2). Thus, the Interactive Partners agreed with participants in the other two groups on an important role for science in decision-making (Statement 10: -2), but disagreed with them by considering more important the establishment of collaborative partnerships between scientists and decision-makers.

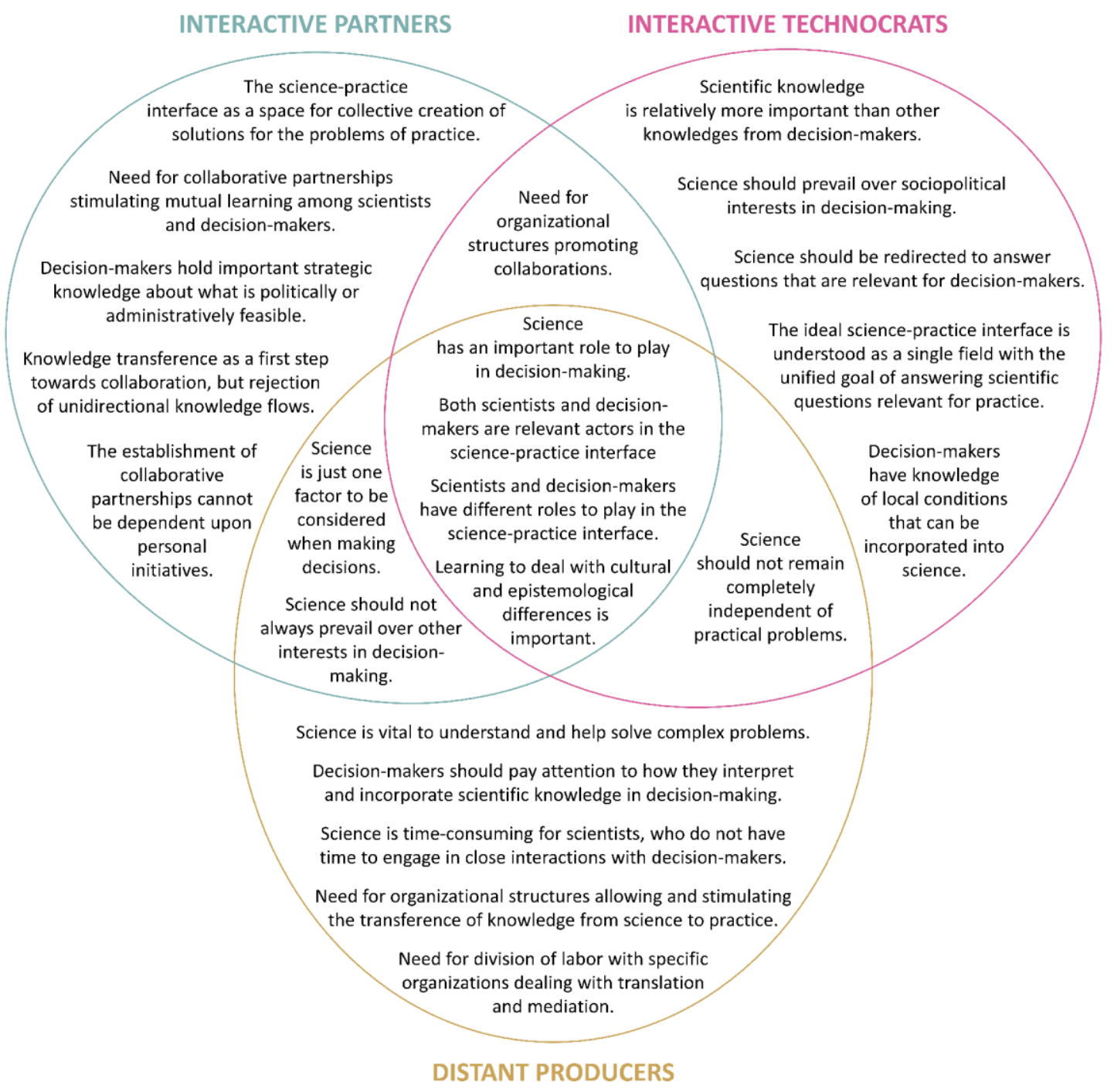

Figure 3. Main ideas characterizing the three different ways of thinking about the science-practice interface in Ecology and Conservation (Interactive Partners, Interactive Technocrats and Distant Producers), showing distinguishing and shared ideas among ways of thinking. 
Similar to the other ways of thinking, the Interactive Partners recognized we must learn to deal with cultural and epistemological differences between scientists and decision-makers, but specifically to facilitate collaborations between them (Statements 3: $+2,18:+2$ ). In addition, these participants argued moderately for scientists (Statements: 13: $+1 ; 34:+1$ ), but not decision-makers (Statement 11: 0), to embrace mutual learning and knowledge coproduction. A crucial point for the Interactive Partners was the idea the incentive for collaborative partnerships must come from within organizations involved in science and practice (Statement 37: +3 ) and not from personal initiatives. One participant complained that "sometimes there is someone who is willing to [engage in knowledge exchange] [...], but the organizational context does not facilitate it. It is always something personal, of one researcher or manager going after it, rather than something built [within organizations]. Maybe this person leaves and then there is no continuity". Yet, the Interactive Partners did not demonstrate preference for any particular type of organizational structure to promote such interactions (Statements 45: 0, 48: -1).

The factor represented by the Interactive Partners had an eigenvalue of 6.641 and explained $30.19 \%$ of the total variance of the 22 Q-sorts, being the most predominant viewpoint in our sample (Appendix S8). Six scientists and four decision-makers were associated with this factor, from all regions of Brazil and varying in their acceptance of positivist beliefs (Appendix S9). Scientists associated with this group presented diverse levels of engagement with practice. In contrast, decision-makers in this group had engaged in the last 5 years more directly with science than decision-makers from other groups, especially through direct participation in scientific research and publishing in scientific journals (Appendix S9). These decision-makers had also engaged in a higher number of activities than those in other groups (Appendix S9).

\section{Participants associated with factor 2: Interactive Technocrats}

The Interactive Technocrats were mainly decision-makers who assigned a very important role for scientific knowledge in determining decisions. They recognized, like participants from other groups, that neither scientists nor decision-makers should act alone to solve the problems faced by decision-makers. However, they rejected more strongly the idea of decision-makers acting alone based solely on their knowledge (Statements: 23: -4, 24: -4) than scientists acting alone or decisions being based solely on scientific knowledge (Statements 5: -3, 25: -2). They also assigned neutral rankings to 
statements giving equal emphasis to actors or knowledges from both science and practice (Statements 33: 0, 43:-1). Thus, although these participants recognized the importance of other types of knowledge (Statement 1:-2), they are technocrats in the sense they gave relatively more weight to scientific knowledge (Statement 10: -3). One participant even emphasized it would be good "if decisions were made only as a result of technical and scientific aspects". Thus, for the Interactive Technocrats, in stark contrast to participants in other groups, science should prevail over other issues, such as political or economic interests, and determine decisions (Statement 47: +2 ). The crucial point for these participants was to incorporate scientific knowledge in the final decision (Statement 44: +4 ), irrespective of decision-makers' personal interests (Statement 38: +2) or interferences arising from the complexity of the several sociopolitical and economic demands (Statement 31: +2). Several participants justified this opinion by referring to previous disappointing experiences when scientific knowledge was disregarded, as exemplified by the decision-maker who complained considering scientific knowledge "is important, but it does not happen. [...] I've seen several times that, because of political forces, we are obligated to leave it [scientific knowledge] aside".

The Interactive Technocrats were more concerned than the other groups with the engagement of scientists in conducting research that focus on questions relevant for practice (Statement 46: +4 ). Moreover, they were less concerned than others with processes and activities of knowledge transference (Statements 22: 0, 40: 0, 14: 0, 32: 0, 17: 0). One participant in this group complained "researchers do not care about generating knowledge that will meet a societal demand or a demand from decision-makers". For participants in this group, science cannot remain disconnected from the issues of practice (Statement 12: -3). They saw scientists as important actors in the science-practice interface that cannot solely report their work in scientific journals and not engage with decision-making (Statement 20: -2). Instead, the role of scientists would be to "generate knowledge in response to societal demands". The Interactive Technocrats reasoned scientists are responsible for talking with decision-makers to better understand their demands (Statement 39: +2). In contrast, they did not perceive decision-makers as responsible for reporting their information needs to scientists (Statement 21: 0). One decision-maker emphasized the ideal science-practice interface is in stark contrast with how scientists behave nowadays: "scientists put themselves in a tower, as owners of knowledge, as powerful, unattainable and inaccessible persons, who know everything and 
do not allow for decision-makers to gain access". The Interactive Technocrats argued the solution for a greater engagement of scientists and generation of relevant scientific knowledge should be to create a single field, where organizations involved in science and practice would work towards the same goals of answering relevant questions and implementing practical protocols (Statement 48: +3 ). For example, one participant stated "the demand should be a single demand so that we can solve the issues of environmental management".

Although with considerable less emphasis than participants associated with the first way of thinking, the Interactive Technocrats also acknowledge the need for interactions, knowledge exchange and mutual learning among scientists and decision-makers (Statements 42: $+3,4:+1$ ). However, while the Interactive Partners perceived decisionmakers as holders of strategic knowledge (i.e., regarding administrative or political restrictions), the Interactive Technocrats emphasized decision-makers have specific knowledge on local conditions, as exemplified by the participant who stated: "you can do the research you want, [...] you will never have the knowledge [of the area] that a manager or a park ranger has". From this viewpoint, scientists should learn about local conditions from decision-makers and report it back to science, thus establishing the bidirectional knowledge flow (Statement 36: +2 ). This is exemplified by the participant who stated that "there is knowledge [...] most of the times hidden [within the decisionmaker], and you as a researcher has the obligation to bring it to surface". Similar to the participants associated with the first viewpoint, these participants considered that, to establish such collaborations, we first need to deal with cultural differences between scientists and decision-makers (Statement 3: +2 ) and create organizational structures allowing and stimulating such collaborations (Statement 37: +3) (Fig. 3). However, in contrast to the Interactive Partners, the Interactive Technocrats demonstrated preference for a specific organizational structure in which organizations involved in science and practice would work towards the same goals, thus stablishing a single field (Statement 48: +3$)$.

The factor represented by the Interactive Technocrats had an eigenvalue of 5.303 and explained $24.11 \%$ of the total variance of the 22 Q-sorts (Appendix S8). Five of the six participants associated with this factor were decision-makers, half of which worked with analyses of environmental impact assessments. The only scientist associated with this factor had one of the highest level of engagement with practice when considering the 
number of different activities executed and the engagement in science interpretation and advocacy (Appendix S9).

\section{Participants associated with factor 3: Distant Producers}

The Distant Producers were scientists who assigned great importance to considering science in decision-making, especially because of the complexity of problems faced by decision-makers (Statement 31: +4). They perceived conservation and environmental problems as complex problems, as exemplified by the participant who stated these problems "nowadays involve a much higher level of scientific complexity. We are thinking about climate change models, limnological system, we are talking about systems, we are talking about interactions". This complexity was thus understood somewhat differently compared to the other viewpoints, for which complexity arose mainly from socioeconomic or political demands, and not from the different interconnected economic, social and ecological systems. The Distant Producers emphasized the strength of scientific knowledge in helping to solve complex problems, exemplified by the participant who argued environmental issues "are uncertain and complex, but this cannot be an excuse for inaction. [...] Scientific knowledge helps us to understand complexity".

Insofar as these participants saw this strength in science, they also perceived science as having limitations to support decision-making. One participant argued "sometimes scientists in academia are not seeing certain things in the real world. Our theories do not capture everything or our perception is biased in some direction, so obviously, when a decision must be made, there are other components that can be more apparent to decisionmakers". The Distant Producers did not care whether other interests, such as political or economic interests, outweigh scientific knowledge in the final decision (Statement 47: 1), as exemplified by the participant who said "sometimes you are going to give a scientific opinion that is economically impracticable [...], and we have to be prepared to understand this as well'". Thus, the Distant Producers were neutral to scientific knowledge being disregarded in decision-making (Statement 44: 0). In this sense, this viewpoint resembles the first one, in which science should enter decision-making processes as one factor to be considered (Fig. 3). However, in contrast to the Interactive Partners, who emphasized collaborations to integrate different knowledges, the Distant Producers underlined the importance and utility of science to understand the complexity arising from 
the interconnections of distinct systems involved in conservation and environmental problems.

Although they agreed with participants associated with the second viewpoint that science cannot remain completely apart from practice (Statement 12: -3) and that scientists should talk to decision-makers to understand their needs (Statement 39: +3 ) (Fig. 3), the Distant Producers did not see the need to change scientific questions (Statement 46: 0). One participant stated that "all scientists work to fill knowledge gaps" and this is sufficient to support decision-making (Statement 41: +3). Another participant explained reducing knowledge gaps is important because "even though sometimes there is no demand for the knowledge today, there may be tomorrow". Thus, the Distant Producers saw their role in the science-practice interface as producers of knowledge that may be helpful for decision-makers. These participants were in fact more concerned than participants in the other groups with how science is used in practice, emphasizing decision-makers should pay attention to how they interpret and incorporate scientific considerations in their analysis (Statements: $38:+4,27:+2$ ). One participant explained sometimes decision-makers read scientific articles, "but in a very selective way. That is, trying to corroborate what he/she already thinks [...]. So I think there is some distortion in the use of science". Other participant emphasized the misinterpretation of science can arise from a lack of understanding of the scientific process and that we need "a more effective program of scientific education, so decision-makers can start thinking more scientifically".

The Distant Producers considered to some extent important that scientists help decision-makers understand science by getting more involved in translating scientific knowledge (Statement 32: +2 ) and not just publishing in scientific journals (Statement 20: -2). One participant stated scientists "have to seek [decision-makers] a little bit more, [...] we must make an effort to send things forward". However, these participants also acknowledged doing scientific research is time-consuming for scientists because "in academia we are already overloaded [...]. We have to teach, we have to train students, so research ends up being just one of our tasks". Thus, for the Distant Producers, an organizational structure that allows and stimulates the transference of scientific knowledge would be important (Statement 7: +2 ). This aspect distinguished this viewpoint from the others, which emphasized organizational incentives for collaborations and not for knowledge transference. The Distant Producers are also distinguished by 
considering the most effective organizational structure to be the creation of specific organizations to work in the interface between science and practice, aiming at mediating their interaction (Statement 45: +3 ). For one participant, "specialized institutions, that mediate and have a structure of technical support for translation [...] would greatly facilitate, because it spares the researchers who has to prepare for it". For the same reason, this group rejected the creation of a single field (Statement 48: -2). One participant argued that "you have scientists with other concerns, other things that are more theoretical, so I don't know if you can think about a single field".

Although the Distant Producers, like participants in the other groups, recognized the importance of considering all actors and knowledge types (Statements 5: -3, 1: -3, 23: $-2,24:-2,10:-3)$, they were less willing to engage in close interactions and collaborations with decision-makers. Among participants across all ways of thinking, the Distant Producers were the least concerned with knowledge exchange, bidirectional knowledge flows, mutual learning and knowledge coproduction among scientists and decisionmakers (Statements 42: 0, 36: $+1,16:-1$ ). One participant in this group assigned relatively more relevance for dialogue, but this was because decision-makers would feel "much more like participants and more empowered, at the end incorporating much more of what is being said [by science]". This is in stark contrast with the first viewpoint, for which scientists have in fact also much to learn from decision-makers and thus should engage in dialogue. The Distant Producers were also more indifferent to scientists adopting a posture that is open to learning in the science-practice interface (Statements: $13:+1,34$ : $0)$.

The factor represented by the Distant Producers had an eigenvalue of 3.26 and explained $14.8 \%$ of the total variance of the 22 Q-sorts (Appendix S8). The three participants associated with this factor were scientists from the same region in Brazil with below-average acceptance of positivist beliefs (Appendix S9).

\section{Main areas of disagreement across ways of thinking}

The distinct ways of thinking about the science-practice interface in Ecology and Conservation can be distinguished by the aspects considered to be the most relevant for an ideal relationship between science and practice (Fig. 3). While the Interactive Partners considered bidirectional knowledge flows to be the most salient aspect (Statement 36, Fig. 2B), the Interactive Technocrats highlighted science should be incorporated in 
decision-making, being prevalent over other aspects (Statements 44 and 47, Fig. 2B). The Distant Producers, in contrast, gave little emphasis to these aspects (Fig. 2B), and instead emphasized the importance of science to help understand complexity and decisionmakers' responsibility to correctly use and interpret scientific knowledge (Statements 31 and 38, Fig. 2B). These differences established some areas of disagreement among the distinct ways of thinking, describe below (Table 4).

First, although there was general agreement that scientific knowledge should support decision-making, participants across viewpoints differed in the role assigned to science in decision-making (Table 4). The Interactive Technocrats emphasized final decisions should ideally be based mainly on technical and scientific aspects so that political or economic interests would have less weight than scientific knowledge. In contrast, the Interactive Partners and Distant Producers reasoned scientific knowledge is only one factor to be considered in decision-making, and thus should not necessarily have more weight than other factors (Statements 44 and 47, Fig. 2B, Table 4). For the Interactive Partners, the importance of science lied in its integration with strategic knowledge of decision-makers, while the Distant Producers highlighted the importance of science to help understand the complexity of the different systems (e.g., ecological, economic and social) involved in environmental problems (Table 4).

Second, participants associated with distinct factors also disagreed on the role of scientists and decision-makers in the science-practice interface (Table 4), even though there was general agreement that both have important contributions to give. For the Interactive Partners, scientists and decision-makers were considered equal partners holding different types of equally important knowledge types: scientific and strategic knowledge. Their role in the science-practice interface would be to engage in collaborations to learn from each other and integrate their knowledge to find solutions for the problems faced by decision-makers. In contrast, the Interactive Technocrats assigned a role of users of science to decision-makers, while scientists would need to support practice by conducting relevant research and to engage with decision-makers to extract their knowledge of local conditions, reporting it back to science. Lastly, the Distant Producers saw their role as scientists mainly as producers of scientific knowledge, assigning to decision-makers the role of interpreters of science.

Finally, participants associated with different viewpoints differed on their willingness to engage in close collaborations between science and practice, with the 
Interactive Partners and Distant Producers being in opposing poles in this aspect (Table 4). However, participants associated to all factors were moderately concerned with creating conditions that allow good relationships between science and practice, either by learning how to deal with cultural and epistemological differences between scientists and decision-makers or by creating organizational structures facilitating interactions. Nonetheless, participants across the three ways of thinking about the science-practice interface differed on the preferred organizational structure (Table 4). While the Interactive Partners were indifferent to this issue, the Interactive Technocrats considered joining organizations involved in science and practice in a single field to be more effective. In contrast, Distant Producers rejected the creation of a single field and argued instead for a third type of organizations that would work in the interface between science and practice, aiming at mediating their interaction.

Table 4. Main areas of disagreement between the three identified ways of thinking about the science-practice interface in Ecology and Conservation.

\begin{tabular}{llll}
\hline $\begin{array}{l}\text { Area of } \\
\text { disagreement }\end{array}$ & \multicolumn{1}{c}{$\begin{array}{c}\text { Interactive } \\
\text { Partners }\end{array}$} & \multicolumn{1}{c}{$\begin{array}{c}\text { Interactive } \\
\text { Technocrats }\end{array}$} & \multicolumn{1}{c}{$\begin{array}{c}\text { Distant } \\
\text { Producers }\end{array}$} \\
\hline $\begin{array}{l}\text { Role of science } \\
\text { in decision- } \\
\text { making }\end{array}$ & $\begin{array}{l}\text { One of the factors to } \\
\text { be considered and } \\
\text { integrated with } \\
\text { strategic knowledge }\end{array}$ & $\begin{array}{l}\text { The most important } \\
\text { factor that should } \\
\text { determine final } \\
\text { decisions }\end{array}$ & $\begin{array}{l}\text { Important to } \\
\text { understand } \\
\text { complexity, but is one } \\
\text { of the factors to be } \\
\text { considered }\end{array}$ \\
$\begin{array}{l}\text { Role of } \\
\text { scientists }\end{array}$ & $\begin{array}{l}\text { Partners and holders of } \\
\text { scientific knowledge }\end{array}$ & $\begin{array}{l}\text { Supporters of practice } \\
\text { by producing relevant } \\
\text { knowledge }\end{array}$ & $\begin{array}{l}\text { Producers of scientific } \\
\text { knowledge }\end{array}$ \\
$\begin{array}{l}\text { Role of } \\
\text { decision- } \\
\text { makers }\end{array}$ & $\begin{array}{l}\text { Partners and holders of } \\
\text { strategic knowledge }\end{array}$ & $\begin{array}{l}\text { Users of science with } \\
\text { knowledge of local } \\
\text { conditions }\end{array}$ & Interpreters of science \\
$\begin{array}{l}\text { Willingness to } \\
\text { engage in } \\
\text { collaborations }\end{array}$ & High & Medium & Low \\
$\begin{array}{l}\text { Preferred } \\
\text { organizational } \\
\text { structure }\end{array}$ & Indifferent & Single field & $\begin{array}{l}\text { Specific organizations } \\
\text { for mediation }\end{array}$ \\
\hline
\end{tabular}




\section{DISCUSSION}

By conducting a Q-methodology study with 22 ecologists and environmental federal analysts in Brazil, we identified three ways of thinking about the science-practice interface in Ecology and Conservation. These viewpoints differed mainly on specific roles assigned to science, scientists or decision-makers, their willingness to collaborate and the organizational structure considered more efficient to stimulate science-practice linkages. Nonetheless, all identified ways of thinking assigned great importance to scientific knowledge to support decision-making, as well as to actors and knowledges from both sides to be involved in the science-practice interface. In the next sections, we first discuss possible explanations for the identified ways of thinking and then derive some implications for advancing productive science-practice linkages in Ecology and Conservation.

\section{Ways of thinking about the science-practice interface in Ecology and Conservation}

Studies utilizing Q-methodology aim at identifying and exploring ways of thinking about a particular subject, revealing nuances of agreements and disagreements on controversial topics (Barry \& Proops, 1999; Watts \& Stenner, 2012). In contrast to typical surveys, studies utilizing Q-methodology do not aim at generalizations, relying on a small number of carefully chosen participants, whose opinions are assessed in detail. By selecting scientists and decision-makers with relevant and diverse opinions, we demonstrated the existence of diverse ways of thinking about the science-practice interface in Ecology and Conservation. Inclusion of other researchers and decisionmakers could reveal other viewpoints, but would not challenge the relevance and interpretations of those described in this study (Brown, 1980). We thus did not aim at evaluating the predominance of these viewpoints in a wider population, which can be later assessed with surveys aiming at quantifying the frequencies of participants associated with each viewpoint (Danielson, 2009).

The three identified ways of thinking about the science-practice interface in Ecology and Conservation cannot be directly associated with proposed theoretical conceptualizations on the subject. Although the viewpoint of the Interactive Partners resembles integrative conceptions based on social learning and coproduction of knowledge among scientists and decision makers (e.g., Roux et al., 2006; Shackleton et al., 2009; Hegger et al., 2012; Pardini et al., 2013), the Interactive Technocrats and 
Distant Producers cannot be fully linked to any specific conceptualization. In some aspects, their view is analogous to the rational-linear model of science being the sole provider of information to decision-making (Albaek, 1995; Nutley et al., 2007; Chapter 1), as they stress either a primacy of scientific knowledge in decision-making (Interactive Technocrats) or the importance of transferring and translating scientific knowledge to decision-makers (Distant Producers). However, they also resemble integrative conceptions by not rejecting other types of knowledges or, as the Interactive Technocrats did, emphasizing bidirectional knowledge flows. Ways of thinking are indeed complex and multifaceted, being constructed based on personal experiences but also judged against ideas of others, thus being influenced by social environments (Watts \& Stenner, 2012). This indicates the importance of studies such as ours that systemically assess intricate shared ways of thinking.

Observed patterns among participants across supporting variables can be used to raise "working hypothesis" (Ockwell, 2008; Cairns et al., 2014) of how shared ways of thinking may arise. While the Interactive Technocrats emphasized a primacy of scientific knowledge in decision-making, this way of thinking was intriguingly shared mostly by decision-makers. Similar results have been reported by Neff \& Larson (2014), with a viewpoint assigning great importance to science shared only by practitioners. This may at first seem counterintuitive, as one could expect decision-makers to assign little relevance to science due to complex and chaotic decision-making contexts, which have been reported to diminish the relevance and usefulness of scientific knowledge in decision-making (Albaek, 1995; Nutley et al., 2007). However, the Interactive Technocrats included several analysts responsible for environmental impact assessments, known in Brazil for being subject to great economic and political pressures (Fearnside, 2013, 2014a, 2014b). Many participants in this group reported frustration with past situations where these pressures prevented scientific knowledge from being considered in decision-making. This suggests the great reliance on science among Interactive Technocrats may have arisen from a frustration with decision-making contexts where interests of specific powerful groups often prevail. In this context, science may be seen as provider of neutral, objective knowledge that would solve power disputes. In fact, among the 22 participants, decision-makers were more favorable to positivist beliefs, especially concerning scientific method being the only way to provide true and objective knowledge about the world. 
In contrast to the Interactive Technocrats, the Interactive Partners assigned equal importance to scientific and strategic knowledge in decision-making and were composed of both scientists and decision-makers. These decision-makers had engaged in scientific research more frequently than decision-makers in other groups. Such increased personal contact with scientists may have increased their willingness to develop partnerships. Moreover, by becoming more acquainted with the research process, they may have developed a less idealized view of science, more similar to those of scientists, discarding the idea of science as a neutral and objective agent that can solve disputes in decisionmaking. The production of scientific knowledge has in fact been described as dependent upon broader societal values, which can influence, for example, which scientific questions are asked and funded or how data are collected and described (Longino, 1990). In addition, when science is brought to assist decision-making, scientific evidence is filtered through the values and beliefs of different involved social groups, which may complicate the debate (Collingridge \& Reeve, 1986; Sarewitz, 2004). The emphasis of decision-makers within the Interactive Partners on integrating their strategic knowledge with scientific knowledge may have originated from a need to counterweigh these perceived limitations in science.

Scientists in the Distant Producers group were in turn less willing to engage in collaborative partnerships than the Interactive Partners, emphasizing instead the importance of science to understand complexity. Environmental and conservation problems have often been reported as complex problems, involving intricate ecological and social systems, where trade-offs between conservation and economic development are common (Carpenter et al., 2009b; Hirsch et al., 2010). As the line of research of the Distant Producers involved complex and broad-scale issues, such as macroecology and climate change, they may have been more familiar with how science can embrace complexity. Moreover, by coming from cities close to the political center of Brazil, their views on the science-practice interface may focus on macro-levels of national policymaking. In these levels, problems can be more complex and involve greater diversity of interests and values, increasing possible complications arising from competing interpretations of scientific evidence (Collingridge \& Reeve, 1986; Sarewitz, 2004; Cairney, 2016). The Distant Producers were indeed unfavorable to positivist beliefs, especially regarding the idea of science as provider of objective and accurate knowledge about the world, an idea that contrasts with the notion of diverse interpretations of 
scientific evidence. Together with an overload of responsibilities as university professors, this could explain why the Distant Producers were less willing to engage in a complex policy-making context.

\section{Directions for linking science and practice in Ecology and Conservation}

The similarities and differences among the three identified ways of thinking about the science-practice interface suggest possible directions for linking science and practice. In Ecology and Conservation as well as other disciplines, cultural differences in values, beliefs, languages, behaviors and working routines between scientists and decisionmakers have often been reported as hindering science-practice linkages (Caplan, 1979; Chapter 1), as these differences can involve distinct normative beliefs on how the world should be (Neilson, 2001). However, our results indicate this may not always be the case. First, although participants considered these cultural differences between scientists and decision-makers important, they agreed on fundamental aspects of the science-practice interface, as all actors and types of knowledge were considered relevant across the distinct ways of thinking. Divergences were subtler than expected by controversies in the literature (Adams \& Sandbrook, 2013; Toomey et al., 2016; Chapter 1), lying on how (rather than whether) scientists and decision-makers should contribute to the sciencepractice interface. Second, by combining scientists and decision-makers in a single analysis, we identified one way of thinking shared by both groups (Interactive Partners). This demonstrates consonant views can be found, as already described for specific conservation issues, such as assisted colonization (Neff \& Larson, 2014) and large carnivore conservation (Mattson et al., 2006). Finally, the idea of two distinct cultures implies homogeneity within communities of scientists or decision-makers (Nutley et al., 2007). However, we encountered heterogeneity within these groups, as neither scientists or decision-makers were associated to only one viewpoint. Similar to our results, White et al. (2008) also reported decision-makers hold distinct ways of thinking about the relationship between science and water management.

Nonetheless, some aspects of the identified ways of thinking about the sciencepractice interface suggest the existence of negative attitudes between scientists and decision makers, often reported to arise from cultural ingrained positions (Caplan, 1979; Roux et al., 2006). For example, the Interactive Technocrats criticized scientists for adopting a distant position and the Distant Producers criticized decision-makers for 
misinterpreting scientific knowledge. However, there was general agreement that learning how to deal with these cultural differences is important for an effective sciencepractice interface. Thus, although some attitudes of scientists and decision-maker may complicate dialogue, both sides seem willing to tackle this issue.

In contrast, our results suggest the lack of organizational incentive for linking science and practice - another commonly mentioned restriction for bridging science and practice across diverse disciplines (Whitmer et al., 2010; Chapter 1) - may indeed be important. We encountered high disposition for engagement in close interactions across participants, but several complained of lack of time and of organizational incentive. Even the Distant Producers, who were less willing to engage, justified this opinion with several other commitments being required by scientific organizations. Thus, the establishment of close interactions between science and practice may be hindered less by individual attitudes or opinions than by organizational structures and reward systems restraining such interactions. This indicates rethinking organizational structures involved in both science and practice is important to foster productive science-practice linkages. In fact, the focus of scientific reward structures on quantity of high impact publications can also affect knowledge production itself, either by decreasing the quality of scientific research (Fischer, Ritchie, \& Hanspach, 2012a, 2012b; Halme, Komonen, \& Huitu, 2012) or preventing interdisciplinary research, which takes longer to accumulate scientific impact than disciplinary research (van Noorden, 2015).

Some directions for organizational structures that foster science-practice linkages can be found in the scientific literature. Scientific institutions could establish reward systems valuing actual impact on the ground (Shanley \& López, 2009; Arlettaz et al., 2010), processes and products of knowledge transference (Holi, 2008), and different forms of scholarship (Whitmer et al., 2010), while similar initiatives could be implemented within organizations involved in practice. Moreover, as the Distant Producers highlighted, fostering a third type of organization with mediating professionals can stabilize the relationship between science and practice against internal reward systems keeping them apart (Guston, 2001). In fact, strategies used within these so called "boundary organizations" vary widely, possibly accommodating all identified ways of thinking about the science-practice interface. Boundary organizations can assist in translation of scientific knowledge to decision-makers, as proposed by the Distant Producers, but can also support coproduction of knowledge among scientists and 
decision-makers (Guston, 2001; Cash et al., 2003; Michaels, 2009), as emphasized by the Interactive Partners. In addition, the Interactive Technocrats focused on establishing a single field where both science and practice would work towards the same goal of answering questions relevant for decision-makers. Collaborative exercises of identifying emerging topics to guide research agendas can help is this endeavor (e.g, Sutherland $e t$ al., 2009; Rudd et al., 2011; Jones et al., 2015) and can occur imbedded in boundary organizations (e.g, White et al., 2008).

Besides creating conditions for science-practice linkages within organizations, our results suggest the need to openly debate disagreements when establishing sciencepractice partnerships. First, a broader discussion regarding which organizational structures to pursue is necessary. More importantly, the expected roles of different actors were varied across viewpoints and should be openly discussed, as different expectations can hinder collaborative integration projects (Tress, Tress, \& Fry, 2005; Raymond et al., 2010) as well as translation, dissemination, and interpretation of scientific findings. However, when debating expectations and deciding roles for each actor in partnerships, caution must be taken concerning consensus that may obscure deeper disagreements, especially in situations with unequal power relations such as when scientific knowledge is used in decision-making (Collingridge \& Reeve, 1986; Wynne, 1996). In these situations, most powerful groups tend to dominate consensus and thus maintain the status quo (Peterson et al., 2005). Instead of aiming towards consensus, acknowledging diversity of opinions and adopting an approach of argumentation and debate may be more democratic and inclusive (Peterson et al., 2005; Carpenter et al., 2009a). The identified agreements on more fundamental aspects of the science-practice interface may provide an important common base for scientists and decision-makers to openly debate divergences without escalating possible conflicts.

The directions we propose here for establishing partnerships among scientists and decision-makers in Ecology and Conservation should be considered within Brazil's particular context. Like most tropical developing nations, Brazil harbors great biodiversity but also presents deep social challenges such as poverty and "flawed" democracy (EIU, 2016). Moreover, environmental regulations have been increasingly challenged by powerful economic groups (Ferreira et al., 2014; Loyola, 2014; Fearnside, 2016; Tollefson, 2016; Azevedo-Santos et al., 2017). However, Brazil is also in a singular position by holding a young science, expanding faster than in most tropical nations 
(Adams et al., 2013; van Noorden, 2014). Within this particular context in which science and the environment are salient topics in the public sphere, ways of thinking about the science-practice interface in Ecology and Conservation can diverge particularly from those in developed nations. Thus, future studies in regions and countries that differ markedly from Brazil are required to identify adequate, context-relevant paths for science-practice linkages.

\section{CONCLUSIONS}

We demonstrated scientists and decision-makers in Brazil hold varied viewpoints on the science-practice interface in Ecology and Conservation. Although participants across the three identified ways of thinking agreed on the importance of involving actors and knowledges from both science and practice, they differed on the roles assigned to science, scientists or decision-makers, the organizational structures considered more effective and the willingness to engage in collaborations. The great reliance on science from some decision-makers may be associated with a frustration towards political and economic pressures dominating decision-making, while increased contact with scientific research may increase perception of science's limitation and thus of a need to integrate scientific and strategic knowledge to solve problems. Moreover, some scientists' unwillingness to engage with decision-makers may arise from a focus on the complexity of environmental issues and of broad-scale contexts of national policy-making, as well as from the burden of commitments required by science organizations.

The several agreements across ways of thinking about the science-practice interface and the identification of a shared viewpoint between scientists and decision-makers indicate that ingrained positions and cultural differences between these main actors may not be the most relevant obstacle for linking science and practice. As long as organizational incentives are implemented, it should not be difficult to bring together scientists and decision-makers willing to collaboratively work to support decisionmaking. However, scientists and decision-makers should openly debate expected roles for scientific knowledge, scientists, decision-makers and organizations before attempting to solve particular environmental problems, paying attention to recognize diversity of opinions and engage in argumentation instead of aiming at simple consensus. Exploring and making diversity of opinions explicit with studies such as ours can help guiding such 
strategy of open debate, and may inspire future studies in regions and countries that present environmental and social contexts different from Brazil.

\section{REFERENCES}

AdAms, J., Pendlebury, D. \& Stembridge, B. (2013) Building BRICKS. Exploring the global research and innovation impact of Brazil, Russia, India, China and South Korea. Thomson Reuters.

AdAms, W.M. \& SANDBRook, C. (2013) Conservation, evidence and policy. Oryx 47, 329-335.

AlBAEK, E. (1995) Between knowledge and power: utilization of social science in public policy making. Policy Sciences 28, 79-100.

Arlettaz, R., Schaub, M., Fournier, J., Reichlin, T.S., Sierro, A., Watson, J.E.M. \& BRAUNISCH, V. (2010) From publications to public actions: when conservation biologists bridge the gap between research and implementation. BioScience 60 , 835-842.

Azevedo-Santos, V.M., Fearnside, P.M., Oliveira, C.S., Padial, A.A., Pelicice, F.M., Lima, D.P., Simberloff, D., Lovejoy, T.E., Magalhães, A.L.B., OrSi, M.L., Agostinho, A.A., Esteves, F.A., Pompeu, P.S., Laurance, W.F., Petrere, M., ET AL. (2017) Removing the abyss between conservation science and policy decisions in Brazil. Biodiversity and Conservation.

BARMUTA, L.A., LinKE, S. \& TURAK, E. (2011) Bridging the gap between 'planning' and 'doing' for biodiversity conservation in freshwaters. Freshwater Biology 56, 180195.

BARRY, J. \& PROOPS, J. (1999) Seeking sustainability discourses with Q methodology. Ecological Economics 28, 337-345.

Brown, S.R. (1980) Political subjectivity: applications of $Q$ methodology in political science. Yale University Press, New haven and London.

CAIRnEY, P. (2016) The politics of evidence-based policy making. Palgrave Macmillan UK, London.

CaIRns, R., SAllu, S.M. \& Goodman, S. (2014) Questioning calls to consensus in conservation: a $\mathrm{Q}$ study of conservation discourses on Galápagos. Environmental Conservation 41, 13-26.

CAPES (2015) Sobre avaliação de cursos. http://www.capes.gov.br/acessoainformacao/perguntas-frequentes/avaliacao-dapos-graduacao/7421-sobre-avaliacao-de-cursos [accessed 2 August 2017].

CAPlan, N. (1979) The two-communities theory and knowledge utilization. The American Behavioral Scientist 22, 459.

Carpenter, S.R., Folke, C., Scheffer, M. \& Westley, F. (2009a) Resilience: accounting for the noncomputable. Ecology and Society 14. 
Carpenter, S.R., Mooney, H.A., Agard, J., Capistrano, D., DeFries, R.S., Díaz, S., Dietz, T., Duraiappah, A.K., Oteng-Yeboah, A., Pereira, H.M., Perrings, C., Reid, W.V., Sarukhan, J., Scholes, R.J. \& Whyte, A. (2009b) Science for managing ecosystem services: Beyond the Millennium Ecosystem Assessment. Proceedings of the National Academy of Sciences 106, 1305-1312.

Cash, D.W., Clark, W.C., Alcock, F., Dickson, N.M., Eckley, N., Guston, D.H., JÄGER, J. \& MitchelL, R.B. (2003) Knowledge systems for sustainable development. Proceedings of the National Academy of Sciences 100, 8086-8091.

Castillo, A., Torres, A., Velazquez, A. \& Bocco, G. (2005) The use of ecological science by rural producers: A case study in Mexico. Ecological Applications 15, $745-756$.

Collingridge, D. \& ReEve, C. (1986) Science speaks to power: the role of experts in policy making. St. Martin's Press, New York.

DANIELSON, S. (2009) Q method and surveys: three ways to combine Q and R. Field Methods 21, 219-237.

Dicks, L.V., WALSh, J. \& Sutherland, W.J. (2014) Organising evidence for environmental management decisions: a '4S'hierarchy. Trends in Ecology \& Evolution 29, 607-613.

EIU (2016) Democracy Index 2016: Revenge of the 'deplorables'. Economist Intelligence Unit.

Esler, K.J., Prozesky, H., Sharma, G.P. \& McGeoch, M. (2010) How wide is the 'knowing-doing' gap in invasion biology? Biological Invasions 12, 4065-4075.

FEARNSIDE, P.M. (2013) Decision-making on Amazon dams: politics trumps uncertainty in the Madeira River sediments controversy. Water Alternatives 6, 313-325.

FEARnside, P.M. (2014a) Brazil's Madeira River dams: a setback for environmental policy in Amazonian development. Water Alternatives 7 256-269.

FEARNSIDE, P.M. (2014b) Impacts of Brazil's Madeira River dams: unlearned lessons for hydroelectric development in Amazonia. Environmental Science \& Policy 38, 164172.

FEARNSIDE, P.M. (2016) Brazilian politics threaten environmental policies. Science 353, 746-748.

Ferreira, J., Aragão, L.E.O.C., Barlow, J., Barreto, P., Berenguer, E., Bustamante, M., Gardner, T.A., Lees, A.C., Lima, A., Louzada, J., PARdini, R., Parry, L., Peres, C.A., Pompeu, P.S., Tabarelli, M., et Al. (2014) Brazil's environmental leadership at risk. Mining and dams threaten protected areas. Science 346, 706-707.

FisCHER, J., RitCHIE, E.G. \& HANSPACH, J. (2012a) An academia beyond quantity: a reply to Loyola et al. and Halme et al. Trends in Ecology and Evolution 27, 587.

FischeR, J., RitchiE, E.G. \& HANSPACH, J. (2012b) Academia's obsession with quantity. Trends in Ecology \& Evolution 27, 473-474. 
Guston, D.H. (2001) Boundary organizations in environmental policy and science: an introduction. Science, Technology, \& Human Values 26, 399-408.

Halme, P., Komonen, A. \& Huitu, O. (2012) Solutions to replace quantity with quality in science. Trends in Ecology \& Evolution 27, 586.

Hanson, T., Brooks, T.M., Da Fonseca, G.A.B., Hoffmann, M., Lamoreux, J.F., Machlis, G., Mittermeier, C.G., Mittermeier, R.A. \& Pilgrim, J.D. (2009) Warfare in biodiversity hotspots. Conservation Biology 23, 578-587.

HARDING, S. (2016) A New Global Dynamic - Recognising the Importance of the Tropics. Journal of Tropical Psychology 6.

Hegger, D., LAmers, M., VAn ZeiJl-Rozema, A. \& DiePerink, C. (2012) Conceptualising joint knowledge production in regional climate change adaptation projects: success conditions and levers for action. Environmental Science \& Policy 18, 52-65.

Hirsch, P.D., AdAms, W.M., Brosius, J.P., Zia, A., BAriola, N. \& DAMmert, J.L. (2010) Acknowledging conservation trade-offs and embracing complexity: conservation trade-offs and complexity. Conservation Biology 25, 259-264.

HoLI, M.T. (2008) Metrics for the evaluation of knowledge transfer activities at universities.

Holmes, G., SANDBrook, C. \& Fisher, J. (2016) Understanding conservationists' perspectives on the new conservation debate. Conservation Biology.

Jones, A.C., Mead, A., Kaiser, M.J., Austen, M.C.V., Adrian, A.W., Auchterlonie, N.A., Black, K.D., Blow, L.R., Bury, C., Brown, J.H., Burnell, G.M., Connolly, E., Dingwall, A., Derrick, S., EnO, N.C., ET Al. (2015) Prioritization of knowledge needs for sustainable aquaculture: a national and global perspective. Fish and Fisheries 16, 668-683.

Knight, A.T., Cowling, R.M., Rouget, M., Balmford, A., Lombard, A.T. \& CAMPBELl, B.M. (2008) Knowing but not doing: Selecting priority conservation areas and the research-implementation gap. Conservation Biology 22, 610-617.

LONGINO, H. (1990) Science as social knowledge - Values and objectivity in scientific inquiry. Princeton University Press, Princeton, NJ.

Loyola, R. (2014) Brazil cannot risk its environmental leadership. Diversity and Distributions 20, 1365-1367.

Mattson, D.J., BYrd, K.L., Rutherford, M.B., Brown, S.R. \& Clark, T.W. (2006) Finding common ground in large carnivore conservation: mapping contending perspectives. Environmental Science \& Policy 9, 392-405.

McKeown, B.F. \& ThOMAS, D.B. (1998) Q methodology (quantitative applications in the social sciences), 2nd edition. Sage, Los Angeles.

MiCHAELS, S. (2009) Matching knowledge brokering strategies to environmental policy problems and settings. Environmental Science \& Policy 12, 994-1011. 
NeFF, M.W . \& LARSON, B.M.H. (2014) Scientists, managers, and assisted colonization: Four contrasting perspectives entangle science and policy. Biological Conservation 172, 1-7.

NeILson, S. (2001) Knowledge Utilization and Public Policy Processes: A Literature Review. IDRC.

VAn NoORden, R. (2014) South America by the numbers. Nature 510, 202-203.

VAN NOORDEN, R. (2015) Interdisciplinary research by the numbers. Nature 525, 306307.

NutLEy, S.M., WALTER, I. \& DAVIES, H.T.O. (2007) Descriptive models of the research impact process. In Using Evidence: How research can inform public services pp. 91-123. Bristol. UK.

OCKWELl, D.G. (2008) 'Opening up' policy to reflexive appraisal: a role for Q Methodology? A case study of fire management in Cape York, Australia. Policy Sciences 41, 263-292.

Pardini, R., Rocha, P.L.B., El-Hani, C. \& Pardini, F. (2013) Challenges and opportunities for bridging the research-implementation gap in ecological science and management in Brazil. In Conservation Biology: Voices from the Tropics pp. 77-95.

PATton, M.Q. (2014) Qualitative evaluation and research methods, 4th edition. SAGE Publications, inc.

Peterson, M.N., Peterson, M. \& Peterson, T.R. (2005) Conservation and the myth of consensus. Conservation Biology 19, 762-767.

PREGERNIG, M. (2014) Framings of science-policy interactions and their discursive and institutional effects: examples from conservation and environmental policy. Biodiversity and Conservation 23, 3615-3639.

Pullin, A.S. \& KNIGHT, T.M. (2003) Support for decision making in conservation practice: an evidence-based approach. Journal for Nature Conservation 11, 83-90.

Pullin, A.S., Knight, T.M., Stone, D.A. \& Charman, K. (2004) Do conservation managers use scientific evidence to support their decision-making? Biological Conservation 119, 245-252.

Raymond, C.M., Fazey, I., Reed, M.S., Stringer, L.C., Robinson, G.M. \& Evely, A.C. (2010) Integrating local and scientific knowledge for environmental management. Journal of Environmental Management 91, 1766-1777.

R DeVelopment Core TeAm (2008) R: A Language and Environment for Statistical Computing. R Foundation for Statistical Computing, Vienna, Austria.

Roux, D.J., Rogers, K.H., Biggs, H.C., Ashton, P.J. \& Sergeant, A. (2006) Bridging the science-management divide: Moving from unidirectional knowledge transfer to knowledge interfacing and sharing. Ecology and Society 11.

Rudd, M.A., Beazley, K.F., Cooke, S.J., Fleishman, E., Lane, D.E., Mascia, M.B., Roth, R., TABor, G., BAKKer, J.A., Bellefontaine, T., BerteauX, D., CANTin, B., Chaulk, K.G., Cunningham, K., Dobell, R., ET Al. (2011) Generation of 
priority research questions to inform conservation policy and management at a national level. Conservation Biology 25, 476-484.

SAndBrook, C., Scales, I.R., Vira, B. \& AdAms, W.M. (2011) Value plurality among conservation professionals. Conservation Biology 25, 285-294.

SAREWITZ, D. (2004) How science makes environmental controversies worse. Environmental Science \& Policy 7, 385-403.

Shackleton, C.M., Cundill, G. \& Knight, A.T. (2009) Beyond just research: experiences from Southern Africa in developing social learning partnerships for resource conservation initiatives. Biotropica 41, 563-570.

ShANLEY, P. \& LÓPEZ, C. (2009) Out of the loop: why research rarely reaches policy makers and the public and what can be done. Biotropica 41, 535-544.

StATE OF THE TROPICS (2014) State of the Tropics 2014 report. James Cook University, Austrália.

Steel, B., List, P., Lach, D. \& Shindler, B. (2004) The role of scientists in the environmental policy process: a case study from the American west. Environmental Science \& Policy 7, 1-13.

STEPHENSON, W. (1935) Technique of factor analysis. Nature 136, 297.

Sutherland, W.J., Adams, W.M., Aronson, R.B., Aveling, R., Blackburn, T.M., Broad, S., Ceballos, G., Côté, I.M., Cowling, R.M., Da Fonseca, G. A B., Dinerstein, E., Ferraro, P.J., Fleishman, E., Gascon, C., Hunter, M., et Al. (2009) One hundred questions of importance to the conservation of global biological diversity. Conservation Biology 23, 557-567.

Sutherland, W.J. \& Pullin, A.S. (2004) The need for evidence-based conservation. Trends in Ecology \& Evolution 19, 305-308.

TOLLEFSON, J. (2016) Brazil debates loosening environmental protections. Nature 539, $147-148$.

ToOmey, A.H., KNight, A.T. \& Barlow, J. (2016) Navigating the space between research and implementation in conservation. Conservation Letters.

Tress, B., Tress, G. \& FRY, G. (2005) Defining concepts and the process of knowledge production in integrative research. In From landscape research to landscape planning: aspects of integration, education and application pp. 13-26. Springer: Heidelberg, Germany.

WATTS, S. \& STENNER, P. (2012) Doing Q methodological research: theory, method and interpretation. Sage, London.

Webler, T., Tuler, S. \& KRUEger, R. (2001) What is a good public participation process? Five perspectives from the public. Environmental management 27, 435450.

White, D.D., Corley, E.A. \& White, M.S. (2008) Water managers' perceptions of the science-policy interface in Phoenix, Arizona: implications for an emerging boundary organization. Society \& Natural Resources 21, 230-243. 
Whitmer, A., Ogden, L., Lawton, J., Sturner, P., Groffman, P.M., Schneider, L., Hart, D., Halpern, B., Schlesinger, W., Raciti, S., Bettez, N., Ortega, S., Rustad, L., Pickett, S.T. \& Killilea, M. (2010) The engaged university: providing a platform for research that transforms society. Frontiers in Ecology and the Environment 8, 314-321.

Whitten, T., Holmes, D. \& MacKinnon, K. (2001) Conservation biology: a displacement behavior for academia? Conservation Biology 15, 1-3.

WORLD BANK (2017) World development indicators. http://info.worldbank.org/governance/WGI/\#reports [accessed 7 June 2017].

Wynne, B. (1996) Misunderstood misunderstandings: social identities and public uptake of science. In Misunderstanding science? The public reconstruction of science and technology pp. 19-46. Cambridge University Press.

YounG, K.D. \& VAN AARDE, R.J. (2011) Science and elephant management decisions in South Africa. Biological Conservation 144, 876-885.

ZABALA, A. (2014) qmethod: A package to explore human perspectives using $Q$ methodology. The R Journal 6, 163-173. 


\section{SUPPORTING INFORMATION}

\section{Appendix S1. Additional information on the methods to develop the set of statements used to investigate the ways of thinking about the science-practice interface in Ecology and Conservation.}

Based on the three conceptions on the science-practice interface in Ecology and Conservation (see main text), we created a structure of topics that statements should cover to describe each conception, and then wrote statements to represent each topic (Table S1). We also included statements not related to any of the three conceptions but describing ideas that logically complement them. For example, although no conception emphasized only decision-makers' involvement in the science-practice interface, we added a statement describing this possibility to counterbalance those emphasizing only the involvement of scientists (third conception) or the involvement of both scientists and decision-makers (first and second conceptions) (Table S1).

To complement this list of statements and check if any important considerations were missing from our Q-set, we also consulted the scientific literature and two-decisionmakers with experience in bridging science and practice. The following articles were used to extract suitable statements:

- Arlettaz, R., Schaub, M., Fournier, J., Reichlin, T.S., Sierro, A., Watson, J.E.M. \& BRAUNISCH, V. (2010) From publications to public actions: when conservation biologists bridge the gap between research and implementation. BioScience 60, 835-842.

- Barbour, M.T., Poff, N.L., Norris, R.H. \& Allan, J.D. (2008) Perspective: communicating our science to influence public policy. Journal of the North American Benthological Society 27, 562-569.

- Brown, S.R. (1980) Political subjectivity: applications of $Q$ methodology in political science. Yale University Press, New haven and London.

- CABIN, R.J. (2007) Science-driven restoration: A square grid on a round earth? Restoration Ecology 15, 1-7.

- Garcia, D.B., Morsello, C., El-Hani, C. \& Pardini, R. (2017) A conceptual framework for understanding the perspectives on the causes of the science-practice gap in Ecology and Conservation. 
- Gray, N.J. \& CAmpbell, L.M. (2009) Science, Policy Advocacy, and Marine Protected Areas. Conservation Biology 23, 460-468.

- Pardini, R., Rocha, P.L.B., El-Hani, C. \& Pardini, F. (2013) Challenges and opportunities for bridging the research-implementation gap in ecological science and management in Brazil. In Conservation Biology: Voices from the Tropics pp. $77-95$.

- Pregernig, M. (2014) Framings of science-policy interactions and their discursive and institutional effects: examples from conservation and environmental policy. Biodiversity and Conservation 23, 3615-3639.

- Roux, D.J., Rogers, K.H., Biggs, H.C., Ashton, P.J. \& Sergeant, A. (2006) Bridging the science-management divide: Moving from unidirectional knowledge transfer to knowledge interfacing and sharing. Ecology and Society 11.

- Singh, G.G., Tam, J., Sisk, T.D., Klain, S.C., Mach, M.E., Martone, R.G. \& CHAN, K.M.A. (2014) A more social science: barriers and incentives for scientists engaging in policy. Frontiers in Ecology and the Environment 12, 161-166.

- SteEl, B., List, P., LACH, D. \& ShindLER, B. (2004) The role of scientists in the environmental policy process: a case study from the American west. Environmental Science \& Policy 7, 1-13. 
Table S1. Structure of topics used to create the Q-set (48 statements) related to how the relationship between science and practice should ideally be. Columns represent distinct conceptions of the science-practice interface, and rows, the different aspects to describe each conception, divided in two groups. The first five rows refer to important elements (e.g., actors, knowledges, processes) of each conception, and the remaining rows are related to how specific processes could be executed or how specific problems should be solved from the perspective of each conception. Processes and problems were taken from the second and third hierarchical level of the framework of Chapter 1. Numbers before statements are the numbers found in Table 3 in the main text.

\begin{tabular}{|c|c|c|c|c|c|}
\hline \multicolumn{2}{|l|}{ Conception } & One Actor & One Knowledge & Two Knowledges & Others \\
\hline \multicolumn{6}{|c|}{ Important elements to describe each conception } \\
\hline \multicolumn{2}{|c|}{ Valued actors } & $\begin{array}{l}25 \text { - Scientists should be } \\
\text { responsible for making } \\
\text { decisions in practice. }\end{array}$ & \multicolumn{2}{|c|}{$\begin{array}{l}43 \text { - Both scientists and decision-makers should be involved in activities to improve } \\
\text { decision-making. }\end{array}$} & $\begin{array}{l}24 \text { - Only decision-makers } \\
\text { should be involved in } \\
\text { activities to improve } \\
\text { decisions-making. }\end{array}$ \\
\hline \multicolumn{2}{|c|}{ Valued knowledges } & \multicolumn{2}{|c|}{$\begin{array}{l}5 \text { - Decision-making should be based solely on scientific } \\
\text { knowledge. }\end{array}$} & $\begin{array}{l}33 \text { - Both scientific knowledge and other } \\
\text { knowledges from decision-makers should } \\
\text { be considered in decision-making. }\end{array}$ & $\begin{array}{l}23 \text { - Decision-makers should } \\
\text { base their decisions only on } \\
\text { their own knowledge of the } \\
\text { situation. }\end{array}$ \\
\hline \multicolumn{2}{|c|}{ Devalued knowledges } & \multicolumn{2}{|c|}{$\begin{array}{l}1 \text { - The knowledge of decision-makers is of little importance to } \\
\text { support decision-making. }\end{array}$} & Do not apply: all knowledges are valued & $\begin{array}{l}10 \text { - Scientific knowledge is of } \\
\text { little importance to support } \\
\text { decision-making. }\end{array}$ \\
\hline \multicolumn{2}{|c|}{ Direction of the relationship } & \multicolumn{2}{|c|}{$\begin{array}{l}22 \text { - Establishing a flow of knowledge from science to practice is } \\
\text { important. }\end{array}$} & $\begin{array}{l}36 \text { - Establishing a bidirectional flow of } \\
\text { knowledge between scientific and practical } \\
\text { spheres is important. }\end{array}$ & $\begin{array}{l}\text { No relevant sentence } \\
\text { encountered }\end{array}$ \\
\hline \multicolumn{2}{|c|}{ Important processes } & $\begin{array}{l}\text { Do not apply: there is } \\
\text { no specific processes } \\
\text { described in the } \\
\text { conception }\end{array}$ & $\begin{array}{l}30 \text { - The link between science and } \\
\text { practice should occur by sequential } \\
\text { processes of generation, communication } \\
\text { and use of scientific knowledge. }\end{array}$ & $\begin{array}{l}16 \text { - Science and practice will be more } \\
\text { effectively brought together through } \\
\text { knowledge coproduction with collaborative } \\
\text { learning among scientists and decision- } \\
\text { makers. }\end{array}$ & $\begin{array}{l}48 \text { - Instead of two distinct } \\
\text { fields of science and practice, } \\
\text { there should be a single field } \\
\text { with scientists and decision- } \\
\text { makers engaged in generating } \\
\text { relevant research questions, } \\
\text { creating knowledge to answer } \\
\text { them and implementing } \\
\text { practical protocols. }\end{array}$ \\
\hline Process & Problem & \multicolumn{4}{|c|}{ Processes and problems: how they can be executed or resolved } \\
\hline $\begin{array}{l}\text { Knowledge } \\
\text { generation }\end{array}$ & $\begin{array}{l}\text { Inefficient } \\
\text { research }\end{array}$ & $\begin{array}{l}\text { Dot no apply: category } \\
\text { does not refer to this } \\
\text { conception }\end{array}$ & $\begin{array}{l}46 \text { - Scientists should be concerned with } \\
\text { conducting research that generates } \\
\text { scientific knowledge that is relevant for } \\
\text { decision-makers. }\end{array}$ & $\begin{array}{l}\text { Dot no apply: category does not refer to } \\
\text { this conception }\end{array}$ & $\begin{array}{l}12 \text { - The generation of } \\
\text { scientific knowledge should } \\
\text { always be independent of the } \\
\text { problems of practice. }\end{array}$ \\
\hline
\end{tabular}




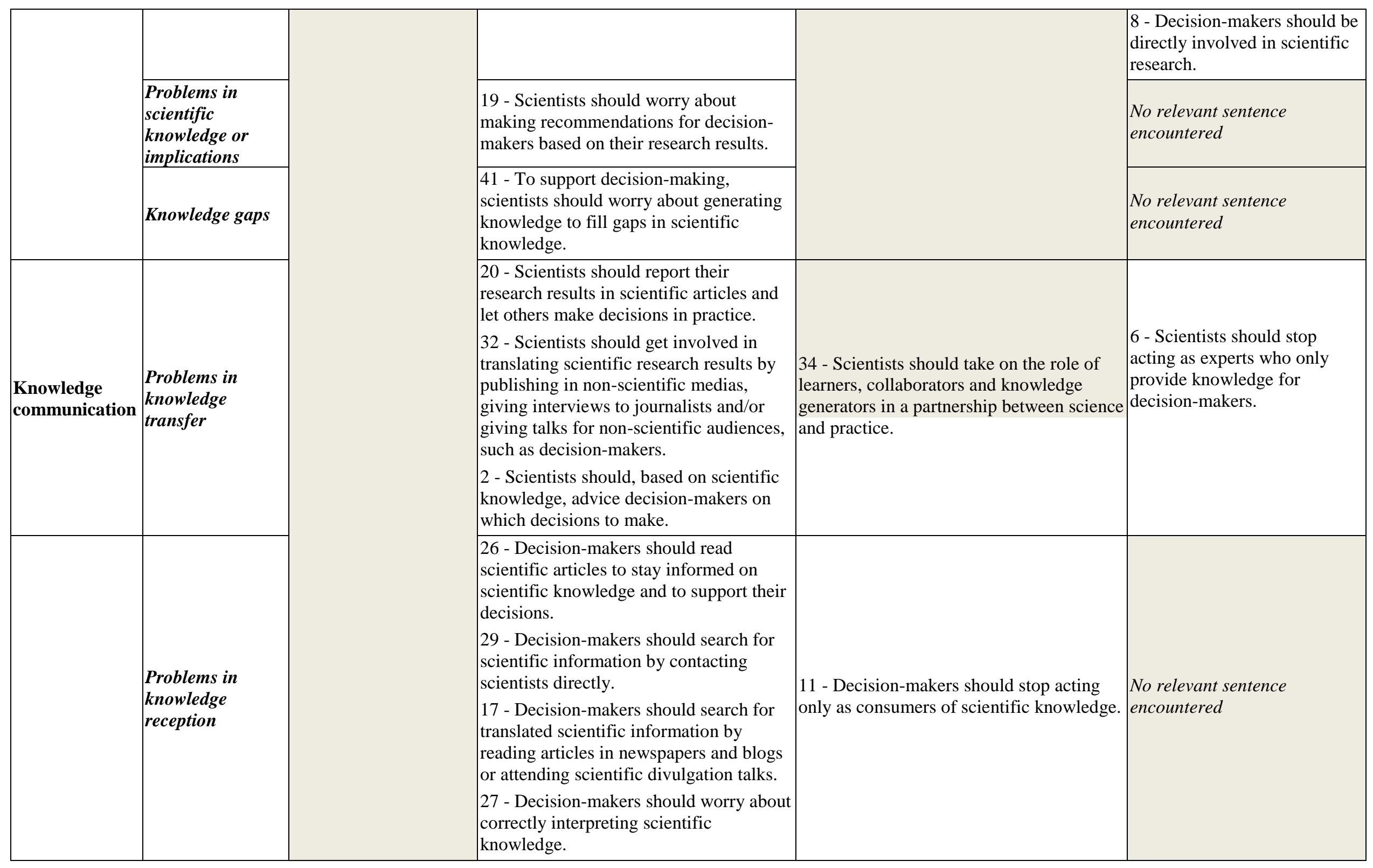




\begin{tabular}{|c|c|c|c|c|}
\hline Knowledge use & $\begin{array}{l}\text { Knowledge } \\
\text { disregarded }\end{array}$ & $\begin{array}{l}44 \text { - Decision-makers should avoid } \\
\text { disregarding scientific knowledge when } \\
\text { making decisions. }\end{array}$ & \multirow{7}{*}{$\begin{array}{l}\text { Dot no apply: category does not refer to } \\
\text { this conception }\end{array}$} & $\begin{array}{l}\text { No relevant sentence } \\
\text { encountered }\end{array}$ \\
\hline \multirow{4}{*}{$\begin{array}{l}\text { Feedback from } \\
\text { practice }\end{array}$} & $\begin{array}{l}\text { Knowledge } \\
\text { selected }\end{array}$ & $\begin{array}{l}38 \text { - Decision-makers should avoid being } \\
\text { influenced by their interests and/or } \\
\text { opinions to partially select which } \\
\text { scientific knowledge to use to support } \\
\text { their decisions. }\end{array}$ & & $\begin{array}{l}\text { No relevant sentence } \\
\text { encountered }\end{array}$ \\
\hline & $\begin{array}{l}\text { Knowledge } \\
\text { surpassed }\end{array}$ & $\begin{array}{l}47 \text { - Scientific knowledge having more } \\
\text { weight than other factors, such as } \\
\text { political and economic interests, in } \\
\text { decision-making is important. }\end{array}$ & & $\begin{array}{l}\text { No relevant sentence } \\
\text { encountered }\end{array}$ \\
\hline & $\begin{array}{l}\text { Lack of } \\
\text { communication } \\
\text { of results }\end{array}$ & $\begin{array}{l}9 \text { - Decision-makers should always } \\
\text { communicate the results of their } \\
\text { decisions and actions to scientists. }\end{array}$ & & $\begin{array}{l}\text { No relevant sentence } \\
\text { encountered }\end{array}$ \\
\hline & $\begin{array}{l}\text { Lack of } \\
\text { communication } \\
\text { of needs }\end{array}$ & $\begin{array}{l}21 \text { - Decision-makers should worry about } \\
\text { reporting back to scientists what } \\
\text { scientific knowledge is needed for } \\
\text { decision-making. } \\
39 \text { - Scientists should worry about talking } \\
\text { to decision-makers to better understand } \\
\text { which scientific knowledge is necessary } \\
\text { for decision-making. }\end{array}$ & & $\begin{array}{l}\text { No relevant sentence } \\
\text { encountered }\end{array}$ \\
\hline \multirow[t]{2}{*}{$\begin{array}{l}\text { General } \\
\text { problems }\end{array}$} & $\begin{array}{l}\text { Cultural } \\
\text { difficulties }\end{array}$ & $\begin{array}{l}14 \text { - Learning to deal with cultural } \\
\text { barriers (i.e., differences in values, } \\
\text { expectations, languages, attitudes and } \\
\text { behaviours) among scientists and } \\
\text { decision-makers is important to establish } \\
\text { the flow of scientific knowledge from } \\
\text { science to practice. }\end{array}$ & & $\begin{array}{l}\text { No relevant sentence } \\
\text { encountered }\end{array}$ \\
\hline & $\begin{array}{l}\text { Difficulties of the } \\
\text { organizational } \\
\text { context }\end{array}$ & $\begin{array}{l}7 \text { - The organizational context (i.e., rules } \\
\text { and structures establishing which } \\
\text { activities are viable) of scientists and } \\
\text { decision-makers should promote the } \\
\text { transference of scientific knowledge from } \\
\text { science to practice. }\end{array}$ & & $\begin{array}{l}\text { No relevant sentence } \\
\text { encountered }\end{array}$ \\
\hline
\end{tabular}




\begin{tabular}{|c|c|c|c|c|c|}
\hline & $\begin{array}{l}\text { Complexity of } \\
\text { problems }\end{array}$ & & $\begin{array}{l}31 \text { - Avoiding that the complexity of } \\
\text { problems faced by decision-makers } \\
\text { prevents them from making decisions } \\
\text { based on scientific knowledge is } \\
\text { important. }\end{array}$ & & $\begin{array}{l}\text { No relevant sentence } \\
\text { encountered }\end{array}$ \\
\hline \multirow[t]{4}{*}{ Interactions } & $\begin{array}{l}\text { Lack of } \\
\text { interactions }\end{array}$ & & $\begin{array}{l}40 \text { - Interactions between scientists and } \\
\text { decision-makers should facilitate the } \\
\text { transference of knowledge from science } \\
\text { to practice. }\end{array}$ & $\begin{array}{l}42 \text { - Interactions between scientists and } \\
\text { decision-makers should promote } \\
\text { knowledge exchange and mutual learning. }\end{array}$ & $\begin{array}{l}\text { No relevant sentence } \\
\text { encountered }\end{array}$ \\
\hline & $\begin{array}{l}\text { Epistemological } \\
\text { difficulties }\end{array}$ & & \multirow{3}{*}{$\begin{array}{l}\text { Dot no apply: category does not refer to } \\
\text { this conception }\end{array}$} & $\begin{array}{l}18 \text { - Learning to deal with differences in } \\
\text { the type of knowledge of scientists and } \\
\text { decision-makers is important to allow for } \\
\text { integration among these two types of } \\
\text { knowledge. }\end{array}$ & $\begin{array}{l}\text { No relevant sentence } \\
\text { encountered }\end{array}$ \\
\hline & $\begin{array}{l}\text { Cultural } \\
\text { difficulties }\end{array}$ & & & $\begin{array}{l}3 \text { - Learning to deal with cultural barriers } \\
\text { (i.e., differences in values, expectations, } \\
\text { languages, attitudes and behaviours) } \\
\text { among scientists and decision-makers is } \\
\text { important to establish collaborations } \\
\text { among them. }\end{array}$ & $\begin{array}{l}\text { No relevant sentence } \\
\text { encountered }\end{array}$ \\
\hline & $\begin{array}{l}\text { Difficulties of the } \\
\text { organizational } \\
\text { context }\end{array}$ & & & $\begin{array}{l}37 \text { - The organizational context (i.e., rules } \\
\text { and structures establishing which activities } \\
\text { are viable) of scientists and decision- } \\
\text { makers should promote interactions and } \\
\text { mutual collaborations among them. }\end{array}$ & $\begin{array}{l}\text { No relevant sentence } \\
\text { encountered }\end{array}$ \\
\hline \multicolumn{2}{|l|}{ Other sentences } & $\begin{array}{l}35 \text { - The } \\
\text { communication between } \\
\text { science and practice } \\
\text { should be resolved with } \\
\text { scientists themselves } \\
\text { putting into practice the } \\
\text { results and } \\
\text { recommendations of } \\
\text { their research. }\end{array}$ & $\begin{array}{l}15 \text { - Scientific questions should first be } \\
\text { resolved so that afterwards a complete } \\
\text { scientific product can be delivered to } \\
\text { decision-makers. }\end{array}$ & $\begin{array}{l}4 \text { - An intellectual contribution from both } \\
\text { parties is important for an effective } \\
\text { communication between scientists and } \\
\text { decision-makers. } \\
13 \text { - When talking to decision-makers, } \\
\text { scientists should be willing to learn from } \\
\text { them. }\end{array}$ & $\begin{array}{l}\text { No relevant sentence } \\
\text { encountered }\end{array}$ \\
\hline \multicolumn{2}{|c|}{$\begin{array}{l}\text { Sentences suggested by consulted } \\
\text { decision-makers }\end{array}$} & \multicolumn{4}{|c|}{$\begin{array}{l}45 \text { - Specific organizations working in the interface between science and practice, with the specific goal of mediating interactions, should be } \\
\text { established. } \\
28 \text { - Legislation being effectively grounded on science is important to assure decision-making will be supported by scientific knowledge. }\end{array}$} \\
\hline
\end{tabular}




\section{Appendix S2 - Additional information on the selection of scientists and decision- makers to participate in the Q-methodology study on the ways of thinking about the science-practice interface in Ecology and Conservation.}

Scientists

To reduce travels costs, we identified scientists fulfilling our criteria (see main text) among the speakers in one of the most prestigious national congress of Ecology. The degree of contact of these scientists with decision-making was evaluated from their curriculum vitae (available online at https://lattes.cnpq.br/). We were able to interview 8 scientists from 4 regions of Brazil during, or just after, the conference. We then traveled to Northeast and Southeast of Brazil to interview other 3 scientists and complete our sample of 11 scientists from all 5 regions in Brazil.

\section{Decision-makers}

To select decision-makers (i.e., analysts from IBAMA), we relied on personal contacts inside IBAMA to indicate two analysts in each region of Brazil they felt had contrasting experiences and perspectives on the science-practice interface, and then traveled to interview them. 


\section{Appendix S3 - Additional information on the supporting variables collected via self- administered questionnaire to assist in the interpretation of the identified ways of thinking about the science-practice interface in Ecology and Conservation.}

Table S2 summarizes the information obtained from all 22 participants through a self-administered questionnaire. We measured attitudes towards the use of ecological knowledge thorough the agreement with a statement describing ecological knowledge is important for environmental decision-making. Attitudes towards positivism were quantified with a 5-item Likert-type scale developed previously in the literature (Steel et $a l .$, 2004, see reference in main text). To measure engagement in activities related to either science (for decision-makers) or practice (for scientists), we asked participants if and how many times they engaged in different activities during two periods (see Table S2). For scientists, the six activities were based on different types of advocacy developed by Steel et al. (2004, see reference in main text), but extended to include other activities scientists could perform in the science-practice interface. For decision-makers, we created a complementary list of activities. For example, we asked scientists whether they had already translated the results of their work for non-scientific audiences. Thus, for decision-makers, we asked whether they had already searched for translated scientific information. Some activities were the same for both groups, e.g., collaborations. 
Table S2. Self-administered questionnaire applied to participants of the Q-methodology study to identify ways of thinking about the science-practice interface in Ecology and Conservation.

\begin{tabular}{|c|c|c|c|}
\hline Variable & Asked for & Question & Values \\
\hline $\begin{array}{l}\text { Attitude towards the use } \\
\text { of ecological scientific } \\
\text { knowledge in } \\
\text { environmental decision- } \\
\text { making }\end{array}$ & $\begin{array}{l}\text { Scientists and } \\
\text { decision-makers }\end{array}$ & $\begin{array}{l}\text { For the following question, please consider "environmental decision-making" } \\
\text { involves the development of environmental policies and/or the conservation or } \\
\text { management of biodiversity and of ecological and socio-ecological systems. } \\
\text { Please assign your level of agreement with the following sentence: } \\
\text { Ecological scientific knowledge should be used to support environmental } \\
\text { decision-making in Brazil. }\end{array}$ & $\begin{array}{l}1=\text { strongly disagree, } 2= \\
\text { disagree, } 3=\text { neutral, } 4= \\
\text { agree, } 5=\text { strongly agree }\end{array}$ \\
\hline $\begin{array}{l}\text { Attitude towards } \\
\text { positivism }\end{array}$ & $\begin{array}{l}\text { Scientists and } \\
\text { decision-makers }\end{array}$ & $\begin{array}{l}\text { Please assign your level of agreement with the following sentences: } \\
\text { - Use of the scientific method is the only certain way to determine what is true } \\
\text { or false about the world. } \\
\text { - The advance of knowledge is a linear process driven by key experiments. } \\
\text { - Science provides objective knowledge about the world. } \\
\text { - It is possible to eliminate values and value judgments from the interpretation } \\
\text { of scientific data. } \\
\text { - Facts describe true states of affairs about the world. }\end{array}$ & $\begin{array}{l}\text { Integer, varying from } 5 \text { to } \\
25 \\
\text { Each sentence: } \\
1=\text { strongly disagree, } 2= \\
\text { disagree, } 3=\text { neutral, } 4= \\
\text { agree, } 5=\text { strongly agree } \\
\text { Total: sum of the values } \\
\text { for each sentence }\end{array}$ \\
\hline
\end{tabular}

General introduction for these questions:

Interaction activities

For the following questions, you may not remember the exact number. In such cases, please answer with your best estimate.

Remember "scientists" are considered the people involved in science and that "decision-makers", the people involved in practice, such as analysts, managers, policy-makers and legislators. Please also consider "environmental decision-making" involves the development of environmental policies and/or the conservation or management of biodiversity and of ecological and socioecological systems.

Translation

Translation - 1 year
Have you ever translated results of scientific research for the public through the $\quad \mathrm{Y}=\mathrm{Yes}, \mathrm{N}=\mathrm{No}$ publication in non-scientific media (newspapers, blogs, etc), interviews to journalists and/or talks for non-scientific audiences?

How many publications, interviews and talks in total have you done ...

- in the last year?
Integer 


\begin{tabular}{|c|c|c|c|}
\hline Variable & Asked for & Question & Values \\
\hline Translation -5 years & & - in the last 5 years? & Integer \\
\hline Interpretation: & & $\begin{array}{l}\text { Have you ever interpreted scientific information directly for decision-makers } \\
\text { involved in public, private and/or non-profit (ONG) organizations? }\end{array}$ & $\mathrm{Y}=\mathrm{Yes}, \mathrm{N}=\mathrm{No}$ \\
\hline Interpretation - 1 year & Scientists & $\begin{array}{l}\text { In how many different events (i.e., meetings, reports, informative hearings, etc) } \\
\text { have you interpreted scientific information directly for decision-makers involved } \\
\text { in public, private and/or non-profit (ONG) organizations ... } \\
\text { - in the last year? }\end{array}$ & Integer \\
\hline Interpretation - 5 years & & - in the last 5 years? & Integer \\
\hline Advocacy: & & $\begin{array}{l}\text { Have you ever openly advocated in favor of a decision based on your scientific } \\
\text { knowledge through participation in campaigns, manifestations or protests, } \\
\text { and/or opinions or talks in public hearings? }\end{array}$ & $\mathrm{Y}=\mathrm{Yes}, \mathrm{N}=\mathrm{No}$ \\
\hline Advocacy - 1 year & Scientists & $\begin{array}{l}\text { In how many campaigns, manifestations, protests, and public hearings in total } \\
\text { have you advocated in favor of a decision based on your scientific knowledge ... } \\
\text { - in the last year? }\end{array}$ & Integer \\
\hline Advocacy - 5 years & & - in the last 5 years? & Integer \\
\hline \multirow[t]{2}{*}{ Consultation: } & & $\begin{array}{l}\text { Have you ever consulted decision-makers involved in public, private and/or } \\
\text { non-profit (ONG) organizations when deciding your research questions? }\end{array}$ & $\mathrm{Y}=\mathrm{Yes}, \mathrm{N}=\mathrm{No}$ \\
\hline & Scientists & $\begin{array}{l}\text { For how many different research projects have you consulted decision-makers } \\
\text { involved in public, private and/or non-profit (ONG) organizations to decide your } \\
\text { research questions... }\end{array}$ & \\
\hline Consultation - 1 year & & - in the last year? & Integer \\
\hline Consultation -5 years & & - in the last 5 years? & Integer \\
\hline Collaboration: & Scientists & $\begin{array}{l}\text { Have you ever got involved in collaboration activities with decision-makers of } \\
\text { public, private and/or non-profit (NGOs) organizations with the goal of }\end{array}$ & $\mathrm{Y}=\mathrm{Yes}, \mathrm{N}=\mathrm{No}$ \\
\hline
\end{tabular}




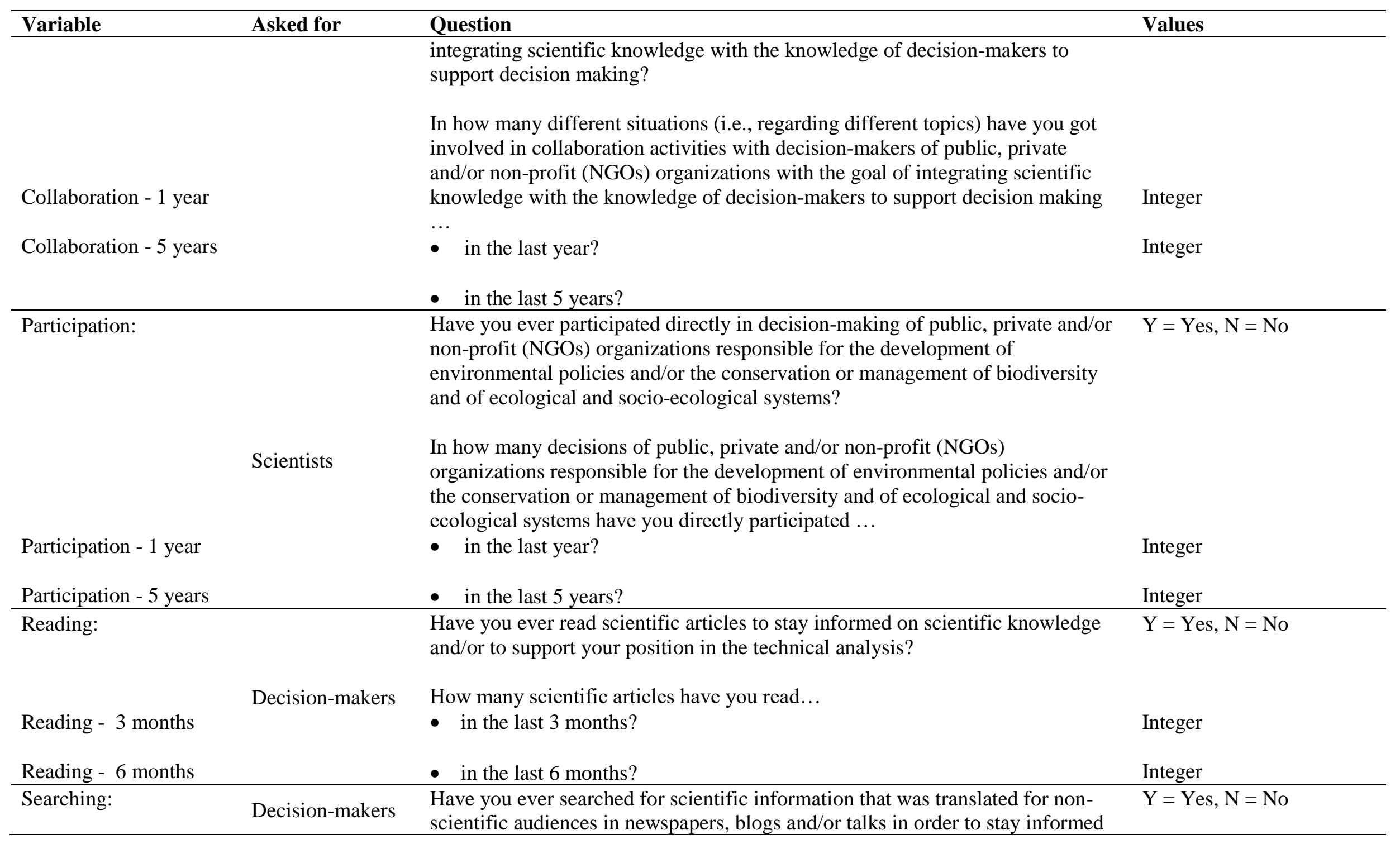




\begin{tabular}{|c|c|c|c|}
\hline Variable & Asked for & Question & Values \\
\hline & & $\begin{array}{l}\text { on scientific knowledge and/or to support your position in your technical } \\
\text { analysis? }\end{array}$ & \\
\hline Searching - 6 months & & $\begin{array}{l}\text { How many newspapers or blog articles and/or talks for non-scientific audiences } \\
\text { have you read or attended in total ... } \\
\text { - in the last } 6 \text { months? }\end{array}$ & Integer \\
\hline Searching - 1 year & & - in the last year? & Integer \\
\hline Contacting: & & $\begin{array}{l}\text { Have you ever contacted directly scientists with the goal of obtaining scientific } \\
\text { information to stay informed on scientific knowledge and/or to support your } \\
\text { position in your technical analysis? }\end{array}$ & $\mathrm{Y}=\mathrm{Yes}, \mathrm{N}=\mathrm{No}$ \\
\hline Contacting - 1 year & Decision-makers & $\begin{array}{l}\text { How many times have you contacted directly scientists with the goal of } \\
\text { obtaining scientific information to stay informed on scientific knowledge and/or } \\
\text { to support your position in your technical analysis ... } \\
\text { - in the last year? }\end{array}$ & Integer \\
\hline Contacting - 5 years & & - in the last 5 years? & Integer \\
\hline Collaboration: & & $\begin{array}{l}\text { Have you ever got involved in collaboration activities with scientists with the } \\
\text { goal of integrating your knowledge (and/or of other analysts) with scientific } \\
\text { knowledge to support your technical analysis? }\end{array}$ & $\mathrm{Y}=\mathrm{Yes}, \mathrm{N}=\mathrm{No}$ \\
\hline & Decision-makers & $\begin{array}{l}\text { In how many different situations (i.e., regarding different topics) have you got } \\
\text { involved in collaboration activities with scientists with the goal of integrating } \\
\text { your knowledge (and/or of other analysts) with scientific knowledge to support } \\
\text { your technical analysis ... }\end{array}$ & \\
\hline Collaboration - 1 year & & - in the last year? & Integer \\
\hline Collaboration -5 years & & - in the last 5 years? & Integer \\
\hline Counseling: & Decision-makers & $\begin{array}{l}\text { Have you ever discussed with or counselled scientists during the planning of } \\
\text { research projects about problems you consider relevant for environmental } \\
\text { decision-making? }\end{array}$ & $\mathrm{Y}=\mathrm{Yes}, \mathrm{N}=\mathrm{No}$ \\
\hline
\end{tabular}




\begin{tabular}{|c|c|c|c|}
\hline Variable & Asked for & Question & Values \\
\hline & & $\begin{array}{l}\text { In how many different research projects have you discussed with or counselled } \\
\text { scientists about problems you consider relevant for environmental decision- } \\
\text { making... } \\
\text { - in the last year? }\end{array}$ & \\
\hline Counseling - 1 year & & - in the last 5 years? & Integer \\
\hline Counseling - 5 years & & & Integer \\
\hline Participation: & & $\begin{array}{l}\text { After entering the career of federal employee in IBAMA, have you ever } \\
\text { participated directly in the execution of scientific research (i.e., in the stages of } \\
\text { planning, data collection, data analysis and/or results interpretation)? }\end{array}$ & $\mathrm{Y}=\mathrm{Yes}, \mathrm{N}=\mathrm{No}$ \\
\hline & Decision-makers & $\begin{array}{l}\text { In how many different research projects have you participated directly in the } \\
\text { execution (i.e., in the stages of planning, data collection, data analysis and/or } \\
\text { results interpretation) ... }\end{array}$ & \\
\hline Participation - 1 year & & - in the last year? & Integer \\
\hline Participation - 5 years & & - in the last 5 years? & Integer \\
\hline Publication: & & $\begin{array}{l}\text { Have you ever published an article, as first author or coauthor, in scientific } \\
\text { journals (i.e., indexed and peer-reviewed journals)? }\end{array}$ & $\mathrm{Y}=\mathrm{Yes}, \mathrm{N}=\mathrm{No}$ \\
\hline & Decision-makers & $\begin{array}{l}\text { How many articles have you published, as first author or coauthor, in scientific } \\
\text { journals (i.e., indexed and peer-reviewed journals) ... }\end{array}$ & \\
\hline Publication - 1 year & & - in the last year? & Integer \\
\hline Publication - 5 years & & - in the last 5 years? & Integer \\
\hline
\end{tabular}




\section{Appendix S4 - Definitions of different terms related to the science-practice interface}

Table S3. Definitions of the different terms related to the science-practice interface in Ecology and Conservation used in the statements presented to participants to assess how they believe the relationship between science and practice should ideally be (see main text).

\begin{tabular}{ll}
\hline Term & Definition for the ecological and conservation context \\
\hline Science & $\begin{array}{l}\text { The structures, processes, products, and people directly involved in the } \\
\text { systematic production of knowledge in Ecology and Conservation Science } \\
\text { within academia. }\end{array}$ \\
Scientists & $\begin{array}{l}\text { The people directly involved in science, as defined above. } \\
\text { The structures, processes, products, and people directly involved in action } \\
\text { and decision-making in public, private and non-profit (NGOs) } \\
\text { organizations responsible for the development of environmental policies } \\
\text { and/or the conservation or management of biodiversity and of ecological }\end{array}$ \\
Practice & $\begin{array}{l}\text { and socio-ecological systems. } \\
\text { The people directly involved in practice, as defined above. This definition } \\
\text { includes, for example, analysts, managers, legislators and policy-makers. } \\
\text { makers }\end{array}$ \\
$\begin{array}{l}\text { Science- } \\
\text { practice }\end{array}$ & $\begin{array}{l}\text { The way by which the relationship, encounter, communication and/or } \\
\text { interface } \\
\text { science and practice (as defined above) occurs. }\end{array}$ \\
\hline
\end{tabular}




\section{Appendix S5 - Original quotations in Portuguese of those presented in main text, extracted from the recorded audio of participants explaining their opinion towards statements describing ideas on how the science-practice interface should ideally be.}

\section{Factor 1}

\section{Quotation in main text}

"the interaction should always be bidirectional, with knowledge generated in academia and the knowledge decision-makers bring from their experience being considered with the same weight. I believe the solution [...] should be the result of integration and interaction between these two knowledge types"

"as a scientist interacting with decision-makers, I am completely willing to listen and try to understand the strategic component of decisions [...] For me, as a biologist, it is very difficult to be aware of all the subtleties of the strategic game of politics"

"when they [scientists and decision-makers] have to work together, they put themselves in each other's shoes and, eventually, the decision-making and the collective enterprise are more realistic"

scientific knowledge "will politically dispute the decision, because decisions will be influenced by several factors and scientific knowledge will have to dispute with them. Eventually, scientific knowledge that is relevant and of quality will have more weight, but eventually not"

"I fully understand there is much more at stake than scientific knowledge, but it would be great if this [scientific evidence] could be set on the table as one of the cards to be played"

\section{Original quotation}

"Eu acho que essa interação deve ser sempre bidirecional, né, considerando no mesmo peso o conhecimento que é gerado na academia e o conhecimento que o tomador traz da sua vivência. Acho que a solução, ela deve se partir de uma coprodução, né, ou seja, resultado da integração e da interação dessas duas formas de conhecimento"

"Como cientista interagindo com tomador de decisão, eu estou totalmente disposto a ouvir e tentar sentir o componente estratégico das decisões que eles têm que fazer [...] para mim, como biólogo, é muito difícil ter noção de todas as sutilizas do jogo estratégico da política"

"No momento em que eles [cientistas e tomadores de decisão] tem que agir juntos, isso faz com que um comece a se colocar no sapato do outro e eventualmente, as tomadas de decisão, não só a tomada, o trabalho em si, o empreendimento coletivo, ele é mais realista."

"Ele [conhecimento científico] tem que disputar politicamente a decisão: a decisão vai estar influenciada por vários fatores e o conhecimento científico vai ter que disputar isso. Um conhecimento científico de qualidade e relevante eventualmente vai ter mais peso, eventualmente não"

"Entendo perfeitamente que existe muito mais coisa em jogo que o conhecimento científico, mas seria sensacional se isso pudesse ser colocado ali na mesa na hora como uma das cartas que estão lá" 
"sometimes there is someone who is willing to [engage in knowledge exchange] [...], but the organizational context does not facilitate it. It is always something personal, of one researcher or manager going after it, rather than something built [within organizations]. Maybe this person leaves and then there is no continuity"

\section{Factor 2}

\section{Quotation in main text}

it would be good "if decisions were made only as a result of technical and scientific aspects"

considering scientific knowledge "is important, but it does not happen. [...] I've seen several times that, because of political forces, we are obligated to leave it [scientific knowledge] aside"

"researchers do not care about generating knowledge that will meet a societal demand or a demand from decision-makers"

the role of scientists would be to "generate knowledge in response to societal demands".

"scientists put themselves in a tower, as owners of knowledge, as powerful, unattainable and inaccessible persons, who know everything and do not allow for decision-makers to gain access"

"the demand should be a single demand so that we can solve the issues of environmental management"
"Às vezes tem uma pessoa que se propõe a fazer [se engajar em troca de conhecimentos], um pesquisador ... mas não tem um contexto organizacional que facilite nesse sentido. Sempre fica aquela coisa pessoal, né, de um pesquisador ou um gestor que vai atrás, mas não necessariamente é uma coisa construída. Às vezes a pessoa vai sair e isso não vai ter continuidade"

\section{Original quotation}

“[...] seria muito bom. Ou seja, que as decisões fossem tomadas meramente em decorrência de aspectos técnicos e científicos"

“É, isso ((aponta para frase 'os tomadores de decisão deveriam evitar que o conhecimento cientifico seja desconsiderado')), é uma coisa importante, que não acontece. [...] E eu já vi acontecer, por força política, a gente se obrigada a chutar o negócio para o lado".

"O pesquisador não se preocupa em gerar um conhecimento que venha atender a uma demanda da sociedade, uma demanda do tomador de decisão"

"O cientista tem a função de gerar conhecimento em atendimento a uma demanda da sociedade em que ele vive"

" $O$ cientista, o pesquisador, se coloca sempre numa redoma, como dono do conhecimento, como uma pessoa poderosa, inatingível, inacessível, que sabe tudo e não lhe permite acesso ao tomador de decisão, que o tomador de decisão tenha acesso"

"A demanda deve ser uma demanda única para que a gente possa resolver a questão da gestão ambiental" 
"you can do the research you want, $[. .$.$] you will$ never have the knowledge [of the area] that a manager or a park ranger has"

"there is knowledge [...] most of the times hidden [within the decision-maker], and you as a researcher has the obligation to bring it to surface"

\section{Factor 3}

Quotation in main text

conservation and environmental problems "nowadays involve a much higher level of scientific complexity. We are thinking about climate change models, limnological system, we are talking about systems, we are talking about interactions"

environmental issues "are uncertain and complex, but this cannot be an excuse for inaction. [...] Scientific knowledge helps us to understand complexity"

"sometimes scientists in academia are not seeing certain things in the real world. Our theories do not capture everything or our perception is biased in some direction, so obviously, when a decision must be made, there are other components that can be more apparent to decision-makers"

"sometimes you are going to give a scientific opinion that is economically impracticable [...], and we have to be prepared to understand this as well"

"all scientists work to fill knowledge gaps"

reducing knowledge gaps is important because "even though sometimes there is no demand for the knowledge today, there may be tomorrow"
"Você pode fazer a pesquisa que você quiser, [...], você nunca vai ter o conhecimento que um gestor ou que um guarda tem"

"Então existe sim, existe um conhecimento, às vezes escondido [no tomador de decisão], às vezes não, na maior parte do tempo escondido, e você como pesquisador tem a obrigação de trazer esse conhecimento à tona"

\section{Original quotation}

"Os nossos problemas em conservação e ambientais hoje envolvem um nível de complexidade cientifica muito maior. Então você está pensando em, sei lá, modelos de mudança climática, sistemas limnológicos, você está falando de sistemas, você está falando de interações"

"Sempre se colocou que [a questão ambiental] é incerto, é complexo, mas isso não deve ser uma desculpa para inação. Então esse é uma questão, é ..., exatamente, o conhecimento científico ajuda a entender a complexidade"

"Às vezes os cientistas dentro da academia não estão vendo outras coisas que estão no mundo real. As nossas teorias não captam tudo ou a nossa percepção é enviesada em algumas direções, então lógico que na hora de você tomar uma decisão pratica, você tem outros componentes que podem estar mais perceptíveis pros tomadores de decisão"

"Às vezes você vai dar uma opinião científica por exemplo, que é inviável economicamente. [...], e a gente tem que estar preparado para entender isso também".

"Mas todo cientista trabalha para diminuir lacuna de conhecimento"

"A redução das lacunas do conhecimento, porque ... às vezes, embora o conhecimento não tenha demanda hoje, ele pode ter amanhã.". 
sometimes decision-makers read scientific articles, "but in a very selective way. That is, trying to corroborate what he/she already thinks [...]. So I think there is some distortion in the use of science"

we need "a more effective program of scientific education, so decision-makers can start thinking more scientifically".

scientists "have to seek [decision-makers] a little bit more, $[\ldots]$ we must make an effort to send things forward"

"in academia we are already overloaded [...]. We have to teach, we have to train students, so research ends up being just one of our tasks"

"specialized institutions, that mediate and have a structure of technical support for translation [...] would greatly facilitate, because it spares the researchers who has to prepare for it".

"you have scientists with other concerns, other things that are more theoretical, so I don't know if you can think about a single field"

decision-makers would feel "much more like participants and more empowered, at the end incorporating much more of what is being said [by science]" "às vezes eles [tomador de decisão] leem [artigos científicos], mas leem de forma muito seletiva. $\mathrm{Ou}$ seja, no sentido de corroborar aquilo que ele já acha que está acontecendo. [...] Então acho que há uma distorção um pouco do uso da ciência nesse sentido"

"Eu sempre falo que a gente tem que passar por um programa mais efetivo de educação científica, inclusive para que os tomadores de decisão comecem a pensar de forma mais cientifica também"

"Eles [cientistas] têm que também procurar [os tomadores de decisão] um pouquinho [...]. Acho que tem que ter um esforço nosso também de colocar isso para a frente."

"A gente, principalmente na nossa academia, a gente já está muito sobrecarregado, [...] A gente tem que ensinar, a gente tem que formar os alunos, quer dizer, então a pesquisa termina sendo uma das nossas coisas"

"Organizações especializadas nisso, que façam essa mediação e tenha uma estrutura de mais apoio técnico à tradução [...] facilita muito porque desonera muito o pesquisador de ter que se preparar para isso"

"Você tem os cientistas com outras preocupações, outras coisas mais teóricas, então, não sei se dá para pensar num campo só.”

"[os tomadores de decisão] se sentem muito mais partícipes e se empoderam mais e também a assim acabam incorporando muito mais o que está colocado ali [pela ciência]" 
Appendix S6 - Additional information on the methods used to define the number of factors for rotation in the principal components analysis conducted to identify shared ways of thinking about the science-practice interface in Ecology and Conservation.

Although the Kaiser-Guttman criteria indicated rotating only the first two factors with eigenvalue (EV) greater than 1 (Watts \& Stenner, 2012), the third factor had a borderline EV of 0.954 (Table S4). In addition, the third factor fell within the less strict application of Humphrey's rule, where factors are selected for rotation when the cross-product of its two highest loadings exceeds one standard error (Watts \& Stenner, 2012) (Table S4). We thus rotated a three-factor solution to ensure we were not missing any important way of thinking. Following interpretation, we retained the third factor because, as explained in the results, it captured an important viewpoint regarding the sciencepractice interface represented by scientists less willing to engage closely with decision-makers.

Table S4. Unrotated components extracted in the principal components analysis of the correlation matrix of Qsorts and analysis of criteria for selecting components for rotation. Q-sorts were produced by each participant after ranking 48 statements describing how the science-practice interface in Ecology and Conservation should ideally be into a ranking scale varying from -4 to +4 , with fixed number of statements per ranking category. The standard error (SE) of the forced distribution was $0.144^{\mathrm{a}}$.

\begin{tabular}{cccccc}
\hline $\begin{array}{c}\text { Extracted } \\
\text { component }\end{array}$ & $\mathbf{E V ~}^{\mathbf{b}}$ & $\begin{array}{c}\text { Variance } \\
\text { explained } \\
(\mathbf{\%})\end{array}$ & $\begin{array}{c}\text { Cumulative } \\
\text { variance } \\
(\mathbf{\%})\end{array}$ & $\begin{array}{c}\text { Q-sorts with } \\
\text { significant loadings } \\
(\mathbf{\alpha}=\mathbf{0 . 0 5})^{\mathbf{c}}\end{array}$ & $\begin{array}{c}\text { Cross-product of } \\
\text { two highest } \\
\text { loadings }^{\mathbf{d}}\end{array}$ \\
\hline PC1 & $\mathbf{1 2 . 9 6 4}$ & 58.9 & 58.9 & $\mathbf{2 2}$ & $0.73^{* *}$ \\
PC2 & $\mathbf{1 . 2 8 5}$ & 5.8 & 64.8 & 1 & $0.15^{*}$ \\
PC3 & 0.954 & 4.3 & 69.1 & 1 & $0.16^{*}$ \\
PC4 & 0.909 & 4.1 & 73.2 & 1 & 0.13 \\
PC5 & 0.755 & 3.4 & 76.7 & 1 & 0.07 \\
PC6 & 0.710 & 3.2 & 79.9 & 1 & 0.10 \\
PC7 & 0.596 & 2.7 & 82.6 & 1 & 0.07 \\
PC8 & 0.514 & 2.3 & 84.9 & 1 & 0.05 \\
PC9 & 0.494 & 2.2 & 87.2 & 1 & 0.07 \\
PC10 & 0.451 & 2.1 & 89.2 & 0 & 0.12 \\
PC11 & 0.363 & 1.7 & 90.9 & 0 & 0.03 \\
PC12 & 0.345 & 1.6 & 92.5 & 0 & 0.03 \\
PC13 & 0.334 & 1.5 & 94.0 & 0 & 0.04 \\
PC14 & 0.273 & 1.2 & 95.2 & 0 & 0.03 \\
PC15 & 0.237 & 1.1 & 96.3 & 0 & 0.04 \\
PC16 & 0.198 & 0.9 & 97.2 & 0 & 0.03 \\
PC17 & 0.142 & 0.6 & 97.8 & 0 & 0.02 \\
PC18 & 0.131 & 0.6 & 98.4 & 0 & 0.01 \\
PC19 & 0.119 & 0.5 & 99.0 & 0 & 0.01 \\
PC20 & 0.089 & 0.4 & 99.4 & 0 & 0.01 \\
PC21 & 0.078 & 0.4 & 99.7 & 0 & 0.01 \\
PC22 & 0.060 & 0.3 & 100.0 & 0.01 \\
\hline
\end{tabular}

${ }^{a}$ Calculated from the equation $S E=1 / \sqrt{N}$, where $\mathrm{N}=$ number of statements in the Q-set (Brown, 1980, see reference in main text).

${ }^{\mathrm{b}}$ Values in bold are the ones that fulfill the Kaiser Gutmman criteria of selecting components with eigenvalue (EV) greater than 1 (Watts \& Stenner, 2012, see reference in main text).

${ }^{c}$ Values in bold are the ones that fulfill the criteria of selecting components with two or more significant loadings (Watts \& Stenner, 2012, see reference in main text).

d Following Humphreys's rule, factors can be selected when the cross-product of its two highest loading exceeds one SE (*) or two SE (**) (Watts \& Stenner, 2012, see reference in main text). 
Appendix S7 - Information on participants' attitudes towards use of ecological science in environmental decision making, attitudes towards positivism and engagement in different activities related to either science or practice.
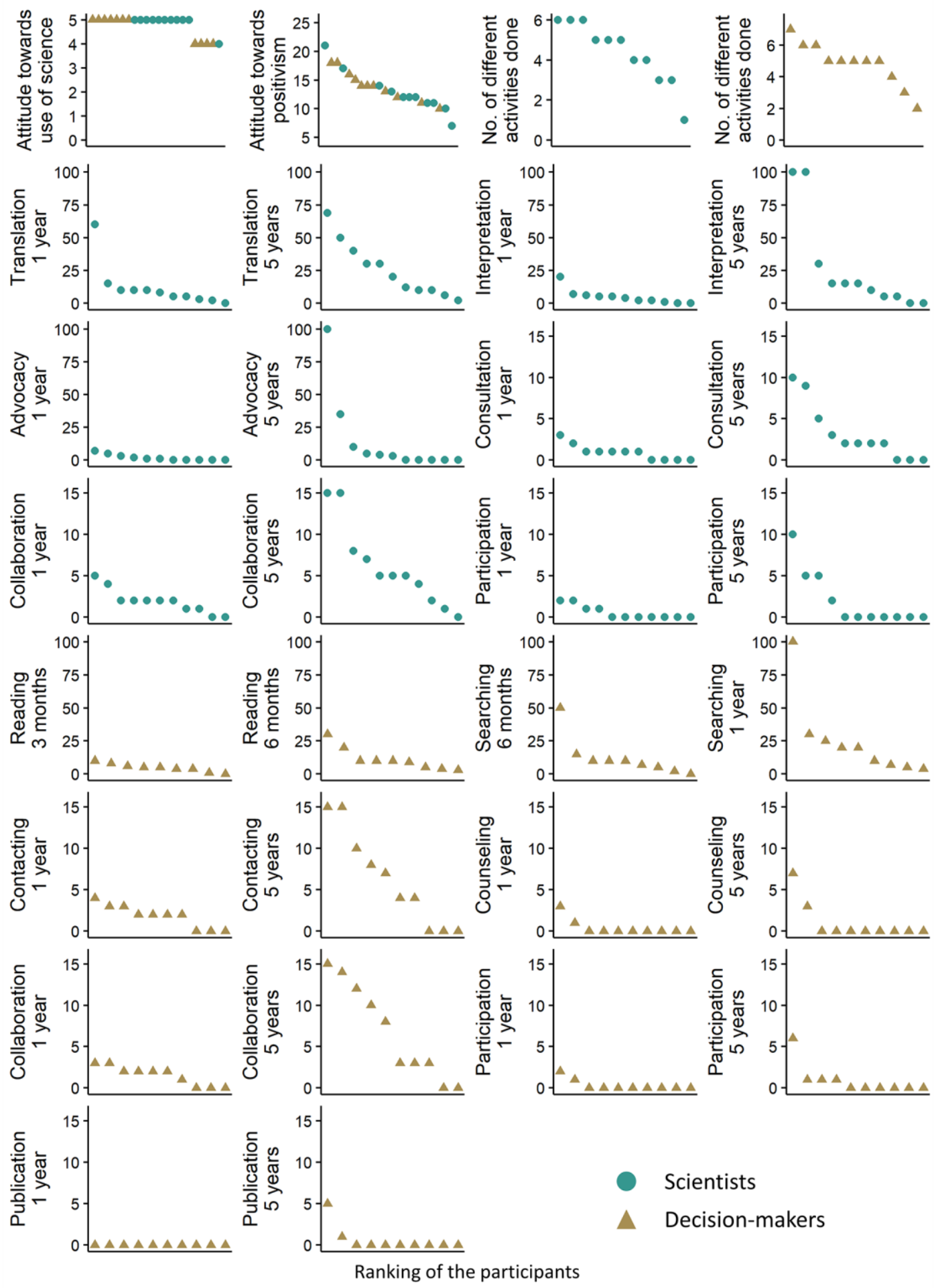

Figure S1. Rank of participants across the variables attitudes towards use of ecological science in environmental decision making, attitudes towards positivism and engagement in different activities related to either science (for decision-makers) or practice (for scientists) (see Appendix S3 for the questions asked). 
Table S5. Number of participants who engaged in the different activities related to either science (for decisionmakers) or practice (for scientists) (see Appendix S3 for the questions asked).

\begin{tabular}{|c|c|c|c|c|c|c|c|}
\hline \multicolumn{4}{|l|}{ Scientists } & \multicolumn{4}{|c|}{ Decision-makers } \\
\hline Activity & $\begin{array}{l}\text { In } \\
\text { their } \\
\text { life }\end{array}$ & $\begin{array}{l}\text { Last } \\
\text { year }\end{array}$ & $\begin{array}{l}\text { Last } 5 \\
\text { years }\end{array}$ & Activity & $\begin{array}{l}\text { In } \\
\text { their } \\
\text { life }\end{array}$ & $\begin{array}{l}\text { Last } \\
\text { year, } \\
\text { semester } \\
\text { or } \\
\text { trimester }^{\mathrm{a}}\end{array}$ & $\begin{array}{l}\text { Last } \\
\text { semester, } \\
\text { year or } 5 \\
\text { years }^{\mathrm{a}}\end{array}$ \\
\hline \multirow{3}{*}{ Translation } & \multirow{3}{*}{11} & \multirow{3}{*}{10} & \multirow{3}{*}{11} & Reading & 11 & $8^{\mathrm{b}}$ & $9^{b}$ \\
\hline & & & & Searching & 11 & $8^{\mathrm{b}}$ & $9^{b}$ \\
\hline & & & & Contacting & 8 & $7^{\mathrm{c}}$ & $7^{\mathrm{c}}$ \\
\hline Interpretation & 9 & 9 & 9 & & & & \\
\hline Advocacy & 6 & 6 & 6 & & & & \\
\hline Consultation & 8 & 7 & 8 & Counseling & 2 & $2^{c}$ & $2^{\mathrm{c}}$ \\
\hline Collaboration & 10 & 9 & 10 & Collaboration & 9 & $7^{\mathrm{c}}$ & $8^{c}$ \\
\hline \multirow{2}{*}{ Participation } & 4 & 4 & 4 & Participation & 5 & $2^{c}$ & $4^{\mathrm{c}}$ \\
\hline & & & & Publication & 7 & $1^{\mathrm{c}}$ & $2^{\mathrm{c}}$ \\
\hline
\end{tabular}

${ }^{a}$ Time period asked was different for each activity. See Appendix S3.

${ }^{\mathrm{b}}$ Two decision-makers did not answer these questions, thus $\mathrm{N}=9$.

${ }^{\mathrm{c}}$ One decision-maker did not answer these questions, thus $\mathrm{N}=10$. 


\section{Appendix S8 - Loading of each participant in the three identified factors}

Table S6. Loading of each participant in the three identified factors, representing the different ways of thinking about the science-practice interface in Ecology and Conservation (F1=Interactive Partners, F2=Interactive Technocrats and F3=Distant Producers), and main research area (for scientists) or function in IBAMA (for decision-makers). Values in grey are the defining Q-sorts for each factor.

\begin{tabular}{lllll}
\hline Participant & F1 & F2 & F3 & Main research area or function in IBAMA \\
\hline Scientist & 0.62 & 0.01 & 0.56 & Conservation, communities, biodiversity \\
Scientist & 0.61 & 0.53 & 0.29 & Population biology, statists, monitoring \\
Scientist & 0.64 & 0.55 & 0.15 & Community ecology, ecology if interactions, conservation biology \\
Scientist & 0.71 & 0.25 & 0.31 & Behavior, sexual selection, parental care \\
Decision-maker & 0.70 & 0.18 & 0.35 & Analysis of processes relating to fisheries \\
Decision-maker & 0.62 & 0.39 & 0.26 & Production of information for environmental surveillance \\
Decision-maker & 0.59 & 0.39 & 0.34 & Environmental impact assessment, focused on hydroelectric dams \\
Decision-maker & 0.77 & 0.27 & 0.21 & Environmental emergencies related to fauna \\
Decision-maker & 0.68 & 0.46 & 0.17 & Analysis of processes related to invasive species management \\
Decision-maker & 0.69 & 0.40 & 0.35 & Environmental impact assessment \\
Scientist & 0.20 & 0.80 & 0.26 & Environmental planning, landscape ecology, ecosystem services \\
Decision-maker & 0.56 & 0.67 & 0.04 & Environmental surveillance \\
Decision-maker & 0.34 & 0.68 & 0.29 & Environmental counsel capacitation, faunal protection, waste \\
Decision-maker & 0.11 & 0.81 & 0.28 & Enviroment \\
Decision-maker & 0.43 & 0.58 & 0.30 & Environmental impact assessment \\
Decision-maker & 0.51 & 0.63 & 0.23 & Environmental impact assessmessment, environmental emergencies \\
Scientist & 0.11 & 0.31 & 0.82 & Macroecology, evolution, statistic \\
Scientist & 0.49 & 0.33 & 0.64 & Ecosystems, biogeochemistry, global environmental change \\
Scientist & 0.51 & 0.26 & 0.58 & Conservation, climate change, biogeography \\
Scientist & 0.56 & 0.56 & 0.10 & Population, communities, impact assessment \\
Scientist & 0.47 & 0.41 & 0.52 & Management, conservation, wildlife \\
Scientist & 0.50 & 0.43 & 0.41 & Community ecology, pollination, interaction networks \\
\hline Eigenvalue & 6.64 & 5.30 & 3.26 & \\
Variance & 30.19 & 24.11 & 14.80 & \\
explained (\%) & & & & \\
\hline
\end{tabular}


Appendix S9 - Additional information on the participants associated with the three identified factors, representing the different ways of thinking about the science-practice interface in Ecology and Conservation.

Table S7. Demographic information of participants associated with the three identified factors, representing the different ways of thinking about the science-practice interface in Ecology and Conservation (F1=Interactive Partners, F2=Interactive Technocrats and F3=Distant Producers).

\begin{tabular}{llll}
\hline & F1 & F2 & F3 \\
\hline $\begin{array}{l}\text { Number of } \\
\text { defining Q-sorts }\end{array}$ & 10 & 6 & 3 \\
$\begin{array}{l}\text { Occupation } \\
\text { Scientist }\end{array}$ & & & \\
Decision-maker & 6 & 5 & 3 \\
Gender & & & \\
Masculine & 5 & 2 & 2 \\
Feminine & 5 & 4 & 1 \\
& & & \\
Region of Brazil & & & \\
South & 1 & 1 & 0 \\
Southwest & 3 & 2 & 0 \\
Center-West & 2 & 0 & 3 \\
Northeast & 3 & 1 & 0 \\
North & 1 & 2 & 0 \\
& & & \\
Highest degree & & & \\
Bachelor degree & 2 & 2 & 0 \\
Master degree & 3 & 2 & 0 \\
PhD degree & 5 & 2 & 3 \\
\hline
\end{tabular}



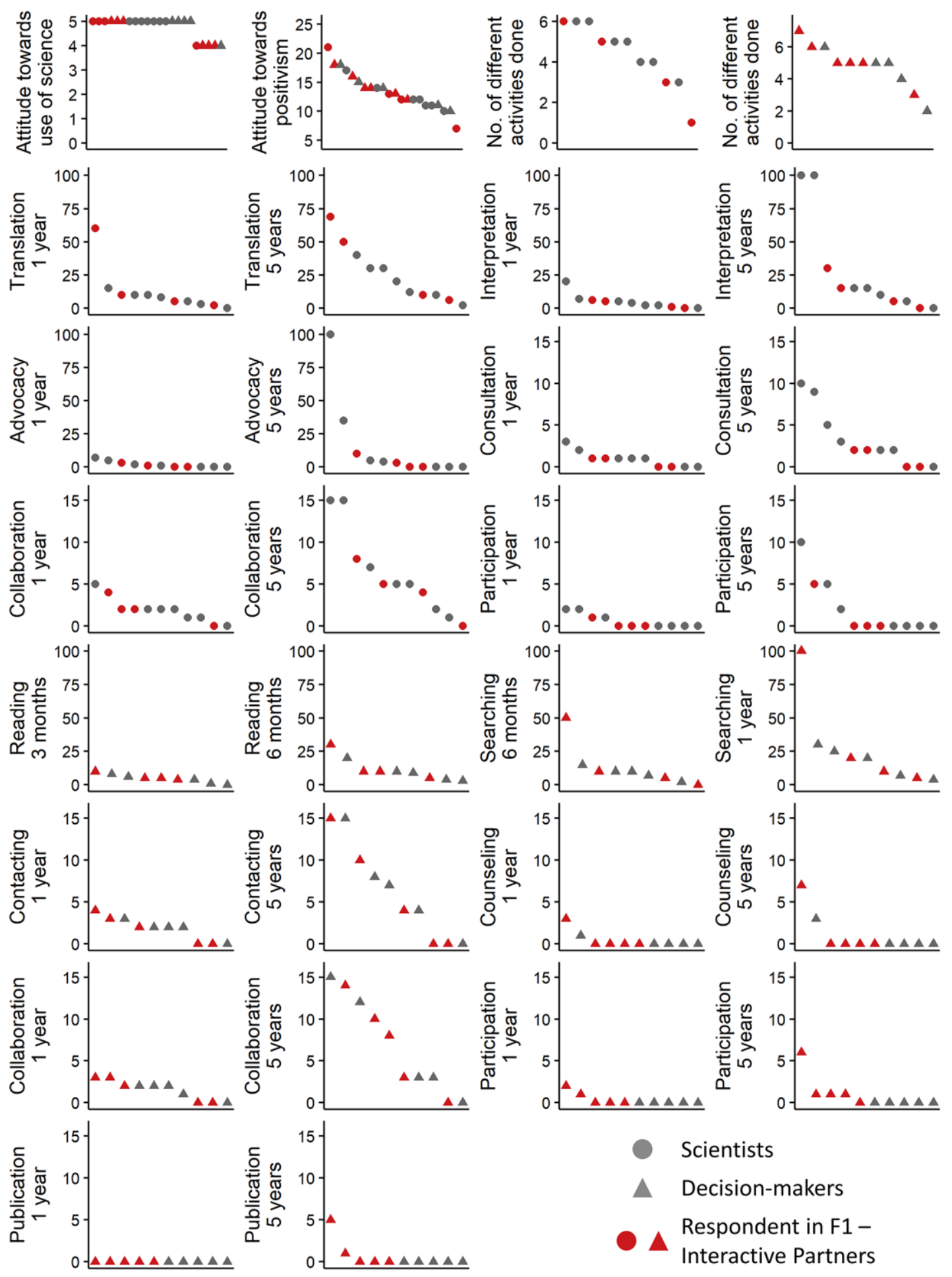

Scientists

$\triangle$ Decision-makers

Respondent in F1 -

Interactive Partners

Ranking of the participants

Figure S2. Rank of participants associated with the first way of thinking about the sciencepractice interface (Interactive Partners, in red) across variables concerning attitudes towards use of ecological science in environmental decision making, attitudes towards positivism and engagement in different activities related to either science (for decision-makers) or practice (for scientists) (as quantified via questionnaire; see Appendix S3). 

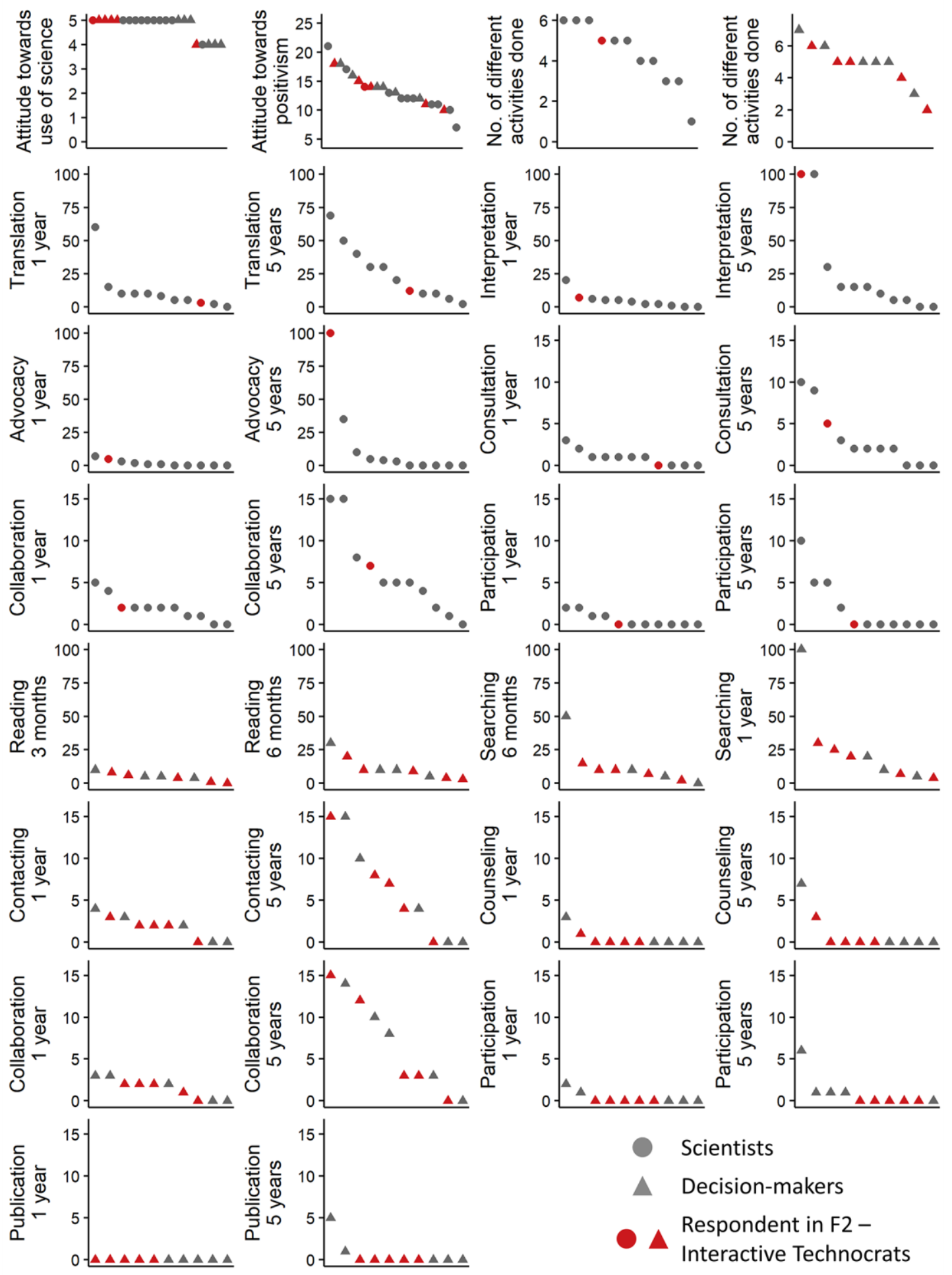

Scientists

$\triangle$ Decision-makers

Respondent in F2 -

Ranking of the participants

Figure S3. Rank of participants associated with the second way of thinking about the sciencepractice interface (Interactive Technocrats, in red) across variables concerning attitudes towards use of ecological science in environmental decision making, attitudes towards positivism and engagement in different activities related to either science (for decision-makers) or practice (for scientists) (as quantified via questionnaire; see Appendix S3). 

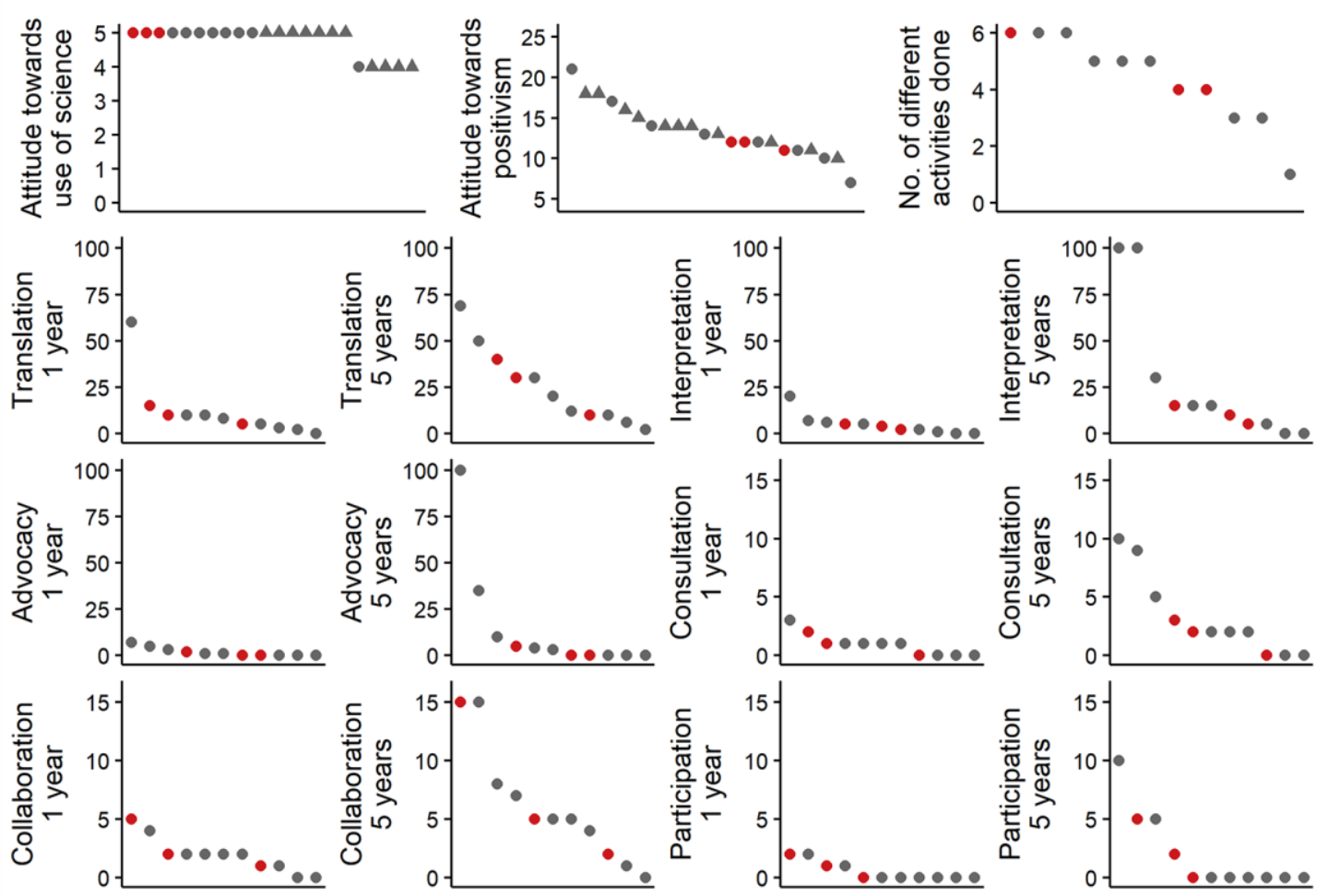

Ranking of the participants

Figure S4. Rank of participants associated with the third way of thinking about the sciencepractice interface (Distant Producers, in red) across variables concerning attitudes towards use of ecological science in environmental decision making, attitudes towards positivism and engagement in different activities related to either practice (as quantified via questionnaire; see Appendix S3) 


\section{CONCLUSION}

In this dissertation, by (1) organizing the perspectives on the causes of the science-practice gap found in the ecological and conservation literature, and (2) identifying shared ways of thinking about the science-practice interface among Brazilian scientists and decision-makers, I aimed at devising ways to effectively navigate the science-practice interface. In chapter 1, I showed the science-practice gap is perceived as a multifaceted problem with a multitude of causes, giving rise to three main conceptual perspectives on the important processes, knowledge and actors in the science-practice interface. While the linear perspective assumes only scientific knowledge should support practice, the integrative perspective assumes both scientists and decision-makers should collaboratively contribute with knowledge to assist decision-making. The last perspective in turn disregard decision-makers by assuming scientists should put their results into practice. Although some causes seemed specific to Ecology and Conservation, others are shared with disciplines such as Medicine and Education, within which similar perspectives on the relationship between science and practice have been recognized.

In chapter 2, I identified three ways of thinking on the science-practice interface in Ecology and Conservation. The predominant viewpoint was shared among scientists and decision-makers who valued the integration of scientific and strategic knowledge to tackle environmental issues. The second was held mostly by decision-makers assigning great importance to science in decision-making and calling for more relevant research. The last was shared by scientists less willing to collaborate, seeing decisionmakers as responsible for correctly interpreting science. Although they differed on the roles assigned to science, scientists or decision-makers, the preferred organizational structures and the willingness to collaborate, all ways of thinking similarly recognized the importance of actors and knowledges from both science and practice. Thus, they cannot be directly linked to the conceptual perspectives arising from the causes of the science-practice gap encountered in the scientific literature, which diverged from each other on the importance assigned to distinct actors and knowledges in the sciencepractice interface. This incongruence suggests a nuanced understanding of the science- 
practice interface and the development of effective science-practice linkages require considering both the conceptual framings and the opinions of involved actors.

A comprehensive understanding of the science-practice interface also depends upon increased dialogue among disciplines and sub-disciplines. In chapter 1, I described the prevalence of the linear perspective on the science-practice interface in Ecology and Conservation, which was possibly associated with the success of evidence-based approaches to link science and practice. The integrative perspective seemed in turn primarily restricted to sub-disciplines historically isolated from mainstream Conservation Biology. The prevalence of the linear perspective was shown to depart from a historical tendency towards integrative perspectives in disciplines that also struggle to envision ways to apply scientific knowledge, such as Medicine and Education. These findings suggest the importance of considering how the sciencepractice interface is understood in different sub-disciplines within Ecology and Conservation as well as across distinct disciplines struggling to apply scientific knowledge. Being transparent about the diversity of perspectives across disciplines and sub-disciplines increases our capacity to find effective solutions to link science and practice, because it fosters a debate that connects isolated propositions and avoids dominance of single models or solutions.

However, because the conceptual perspectives on the science-practice gap in Ecology and Conservation (and probably also in disciplines such as Medicine and Education) reflect an outdated view of decision-making, understanding how to link science and practice also require interdisciplinary work comprising the fields dedicated to study decision-making and the role of science in decision making. Although the linear perspective implied a more simplistic and rational view of decision-making, all identified perspectives were shown to overlook several important aspects of the decision-making processes, such as the limits to human rationality, the complexity of actors, social groups and interests influencing decisions and a potential ambiguity brought about by science. In chapter 2, some of these aspects, e.g., diverse values and powerful political and economic interests, were indeed recognized as influential in the science-practice interface by Brazilian scientists and decision-makers. For instance, the great reliance on science from some decision-makers was associated with a frustration towards political and economic pressures dominating decision-making. Hence, complex and chaotic decision-making contexts may in fact hinder the use of science to 
support practice, and the disregard of decision-making processes is thus a key limitation of ecologists and conservation scientists' propositions on how to use science to support practice.

On the other hand, the fields studying decision-making and the role of science in decision making commonly overlook the processes of knowledge generation, communication and integration, which are as important as decision-making processes to productive science-practice linkages. Concerning the causes of the science-practice gap related to the processes of knowledge generation, communication and integration, I proposed in chapter 1 three general types of solutions depending on the nature of the causal factor. Some identified causes could be tackled by directly eliminating the causal factor, for example, creating lists of priority research topics developed through consultation with decision-makers to confront inadequate research questions. Other causes are related to intrinsic characteristics of scientific knowledge (e.g., scientific uncertainty) and, as such, cannot not be eliminated. Solutions should thus involve the recognition of these characteristics, and then ways to deal with their consequences. Lastly, some causes are based on misconceptions, such as the perceived cause associated with scientific knowledge being abstract. In these cases, solutions require solving misconceptions, for example, by fomenting discussions on the nature of knowledge among scientists and decision-makers.

Besides embracing the intricate nature of the decision-making processes, and recognizing that different types of solutions will be required, rearranging organizational structures of science and practice appears in this dissertation as a key point for effective science-practice linkages. In chapter 1 , I show that difficulties associated with the organizational context, as diverse as formal education and evaluation systems of either science or practice, are commonly perceived causes of the science-practice gap in Ecology and Conservation. Transforming undergraduate and graduate courses to train for engagement with people from diverse backgrounds was then identified as a critical way for scientists and decision-makers to be better prepared to navigate the sciencepractice interface. In chapter 2, current evaluation systems were identified as a hindrance to interactions between scientists and decision-makers, as most participants complained about a lack of organizational incentive. Moreover, some scientists' unwillingness to collaborate with decision-makers was possibly associated with a burden of commitments required by science organizations. Thus, implementing 
scientific evaluation systems that reward other forms of scholarship besides publication in scientific journals is of foremost importance.

Finally, I identified in chapter 1 that collaborative partnerships based on social learning among scientists and decision-makers can be effective for linking science and practice, as they can account for inclusive and democratic decision-making processes, and allow for explicit discussions of values and scientific interpretations. Complementing the broader, theoretical support for integrative approaches in chapter 1 , several findings in chapter 2 indicate a facilitated path for collaborative partnerships among Brazilian scientists and decision-makers. There was high support for collaborative work between scientists and decision-makers across all identified ways of thinking about the science-practice interface. Besides, the predominant way of thinking was shared among scientists and decision-makers and emphasized the importance of mutual learning and coproduction of knowledge between them. Lastly, increased contact of decision-makers with scientific research was associated with higher willingness to engage in knowledge integration to solve environmental problems. Thus, as long as organizational incentives are created, an integrative approach to link science and practice may not be difficult to implement in the Brazilian context. Nonetheless, due to differences across ways of thinking on assigned roles to science, scientists or decision-makers, these roles should be openly debated. Paying attention to recognize diversity of opinions and engage in argumentation instead of aiming at simple consensus will create a more democratic and effective process to link science and practice in Ecology and Conservation. 